
Hew tate (Tallege af Agricultur At Gornell Altriuersity

Tibraxy

thoriculture 
SB 421 Cornell University Library

Alpines and bog-plants,

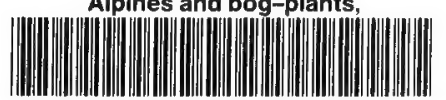

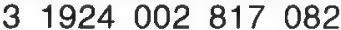




\section{Cornell University Library}

The original of this book is in the Cornell University Library.

There are no known copyright restrictions in the United States on the use of the text.

http://www.archive.org/details/cu31924002817082 
ALPINES AND BOG.PLANTS 


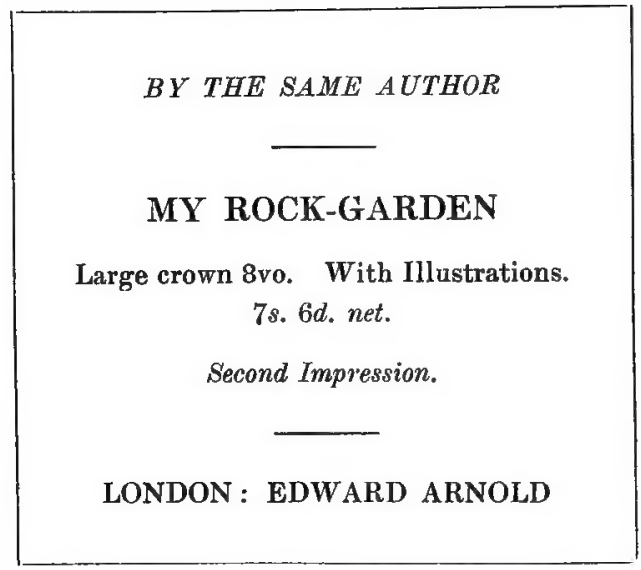





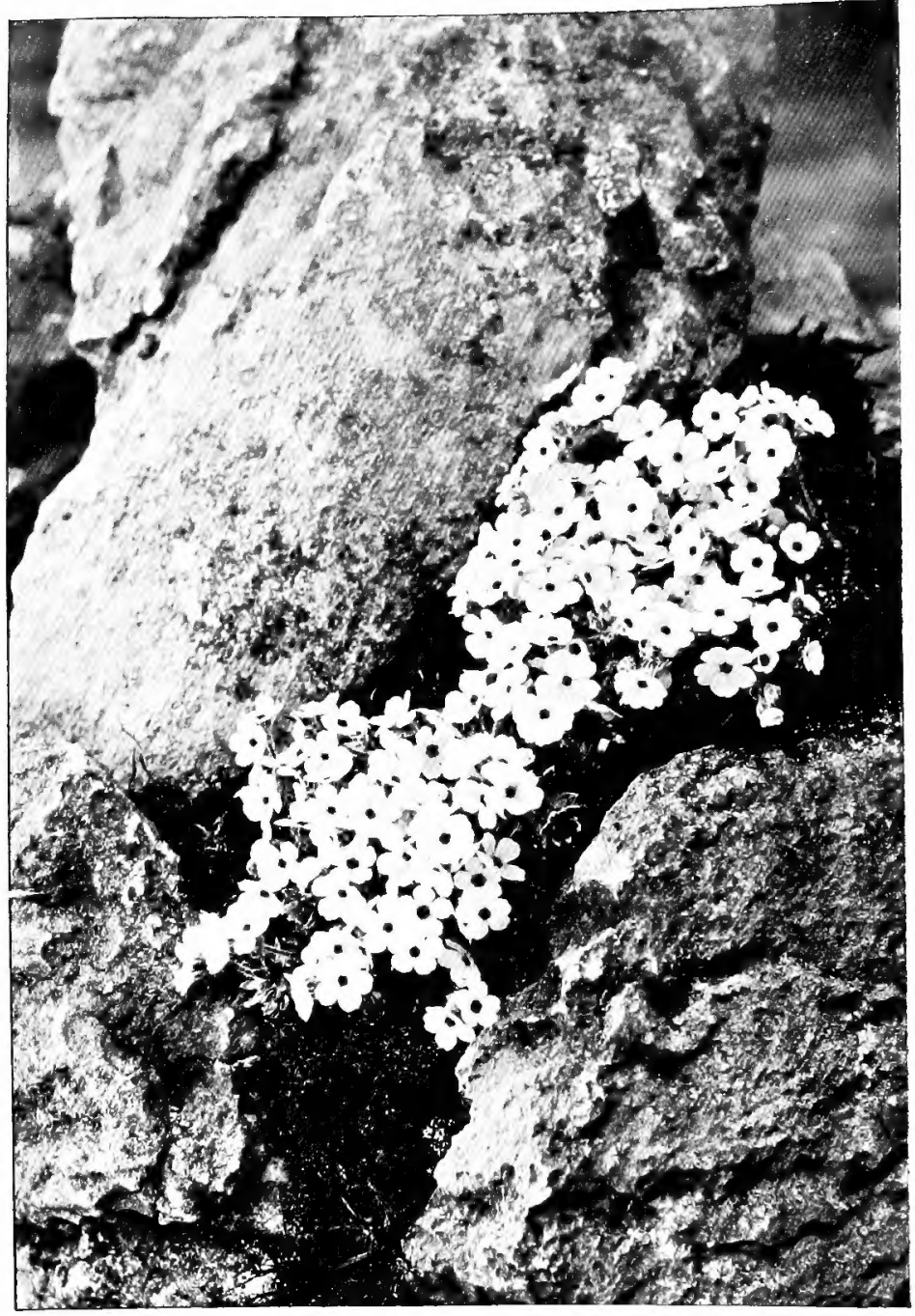

AXIROSACE VILLOSA. 




\title{
ALPINES AND BOG-PLANTS
}

\author{
BY \\ REGINALD FARRER \\ AUTHOR OF 'MY ROCK-GARDEN,' ETC.
}

WITH ILLUSTRATIONS

LONDON

EDWARD ARNOLD

1908

All rights reserved 


$$
\begin{gathered}
\text { SB421 } \\
\text { F2 }
\end{gathered}
$$

@19402 


\section{MY MOTHER}

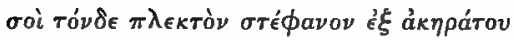

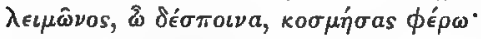

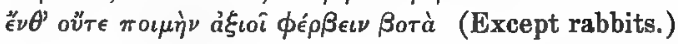

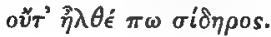

Hippolyros, 72-6. 



\section{P RE FA C E}

I wILL not apologise, this time, for inviting enthusiasts to accompany me round my little territories: for so large a company was kindly enough to take pleasure in My Rock-Garden, that now I am sure that those who enjoyed the earlier book will be pleased to find, in this volume, all the treasured rarities and delights which pressure of space forbade me to include in its predecessor -or, rather, forced me, with bitter lamentations, to excise from its mutilated pages. With all the more joy, then, do I offer this timely reparation, no less to my friends who read than to my friends who are written of - to the countless omitted beauties of my garden, whom I had seemed to pass over in an ungrateful silence.

\section{REGINALD FARRER.}

October 1908. 



\section{ONTENTS}

CHAP.

PAGE

I. OF SHRUBS AND THEIR PLACING . . 1

II. OF SHRUBS, MOSTLY EVERGREN 26

III. Ranunculaceae, Papaveraceae, Cruciferae . 49

IV. A COLLECTING DAY ABOVE AROLLA • 68

v. BETWEEN DIANTHUS AND EPILOBIUM • 94

VI. FROM EPILOBIUM ON THROUGH UMBELLIFERAE AND COMPOSITAE . . . 118

VII. OF ODD TREASURES $\quad$ - 132

VIII. THE BIG BOG AND ITS LILIES

IX. THE GREATER BOG-PLANTS + . 172

X. IRIS $\quad$ - $\quad$ - $\quad$. 195

XI. THE MOUNTAIN BOG $\quad . \quad \ldots \quad . \quad 2 \quad . \quad 215$

XII. MORE OF THE SMALLER BOG-PLANTS • $\quad 237$

XIII. THE WATER-GARDEN $\quad$ - $\quad 259$

INDEX . . . $\quad 281$ 


\section{IST OF PLATES}

Androsace villosa. - Frontispiece

EDraianthus gerpyllifolius major to face page 20

INCARVLLEA GRANDIFLORA. 40

Edraianthus pumilo and Saxifraga caesia

Campanula barbata and C. pusilua. Photograph by J. A. Farrer, Esq.

Dianthus neglectus. Photograph by J. A. Farrer, Esq.

Oxalis enNeaphylla 108

'Children of the Mist'-Saxifraga Burnati and Saxifraga cochlearis. Photograph by J. A. Farrer, Esq. . . . . . . $\quad$, 126

Granium inancastriense, Etatines - Campanula, and Antirrhinum gLUtinosum

Aquilegia glandulosa. Photograph by J. A. Farrer, Esq.

Saxifraga cotyledon

Iris tectonum. Photograph by J. A. Farrer, Esq. . 202

Cystopteris montana and Maranthemum bifolium 
Ramondia Nataliae . . . . to face page 254

Primula involuchata, Primula cortusoeides,

Primula neorum, . $\quad$. . . $\quad$ " 270

The plates, except where otherwise stated, are from photographs by Mr. Horner, of Settle, Yorkshire, and all were taken in the Author's own gardens. 


\section{ALPINES AND BOG-PLANTS}

\section{CHAPTER I}

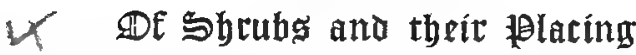

Now, the supreme test of the rock-gardener's craft lies in the placing of his shrubs. Without expecting of any European the unerring tact of Chinese and Japanese in combining rock-work with shrub-life until a mighty precipice is imitated, to perfect scale, within a space of two or three yards of built-up stone, clothed, at all the right points, with what seems the tormented, windflogged vegetation of a thousand years, yet one may deplore the sad fact that too often shrubs are dumped at haphazard into the rock-garden, like punctuation into some women's letters, with no regard for relevance. As a matter of fact, too much importance can hardly be set on the right placing of big and little bushes among the boulders-as by their wise disposition the scheme of the whole may be keyed up to grandeur and illusion, or reduced to a mean chaos. Of course the rules in this matter are a question for individual observation; yet here, perhaps, it is more possible than elsewhere to point out definite details of right or wrong. For instance. On the top of a mimic cliff plant prostrate overhanging Junipers and Retinosporas-which, by curling reluctantly over its rim, will give an impression of height and ferocity to the rock-face. At the bottom, to one side or to the other, set pillar Junipers, blue columnar Junipers, any slender upright evergreen; for this, in turn, will add 
immensely to the height and dignity of the rock. In its face, to preserve and enhance the effect, you may insert Juniperus sanderiana, or lovely little Pinus sylvestris beuvronensis - a perfect Scotch fir in miniature, identical in form and grace with its giant prototype, and therefore, by its suggestion of being a great aged tree, making the rock to which it clings into a very Cheddar Cliff or $\mathrm{El}$ Capitan.

The great point to aim at is the preservation of scale. The view should be so arranged that these little shrubs cease utterly to seem little shrubs. And this is no preachment of unworthy pretentious artifice, it is the logical carrying out of the artistic principles upon which the Noble and Ancient Craft of the Rock-Garden is based. For, in the beginning, the Rock-Garden, springing, like all our noblest achievements in Art, Religion, and Philosophy, out of the East, was far more intimately allied with evergreen shrubs than with the ephemeral glory of flowers. A beautiful Mimêsis of Nature was wanted, and, in the rocky glens that the garden set itself to follow, evergreens play a far greater and more permanent part than flowers. It is our risk that we have introduced a complicating note into the rock-garden by looking on it not only (and, I fear, subordinately) as a piece of mimic mountain-scape, but also as a territory designed and adapted for the growing of particular flowers. But the flowers are so beautiful that no real division of our allegiance may fairly be dreaded-so long as we remember that shrubs, together with rock, make the backbone, the salient note of the rock-garden, and that the placing of our shrubs is no less vital than the placing of our rocks.

Let no one tell me I am preaching too high a gospel. If you are going to build a rock-garden, it is quite as easy and quite as satisfactory to build it right as to build it wrong. And the space at your disposal makes 
no difference whatever. It is as easy to be right, and as fatal to be wrong, in four feet of ground-or four inches -as in four acres. Critics, public and private, said of My Rock-Garden that it would depress the gardener whose opportunities were small, by insisting on vast unattainable perfections. Therefore let me here make my vehement Apologia by declaring that such an accusation ought to be, and surely is, absurd. For, as a matter of fact, the smaller the rock-garden the easier it is to build it beautifully and in harmony. It is in dealing with big ambitious spaces that the designer can most readily go astray. But in a ten-yard strip at Brixton or Balham you can triumphantly enjoy a thing of beauty as perfect as the Kencho-ji or the Koraku-en-yes, and a paradise as rich in lovelinesses as any upland prairie of the Alps. And the key to all this perfection is not space, or money, or ambitious stonework. The key is simply the one word, proportion. Proportion, above all, in placing the stone you have, proportion in adjusting to your stones the miniature pines and firs you set among them. With six stones, two conifers, and four Alpines, I would engage to make in a yard of ground a view that should be beautiful and satisfying and harmonious.

This is not the vain boast of a hierophant, but the plain statement of one who loves alike both tree and rock. Anybody in the world with eyes to see, with five shillings to spend, and six feet or so of soil to spend it on, can easily do as well, and very likely a great deal better-seeing that I only speak from affection and experience-not from any secret store of occult wisdom. If any reader doubts me, let him take two plain blockshaped mossy stones, of which the one is larger than the other. Let him lay the smaller on a downward slope from left to right; let him lay the other, the larger, behind it, on a downward slope from right to left, so that their ends 
overlap by three or four inches. Then, at the inner extremity of the nearer block-the smaller-let him set a tiny pillar Juniper. (He must proportion the size of this for himself, of course, according to the size of his boulders.) Thus the point of the $V$ formed by the two stones will be two inches or so to the tree's left. 'Then let him fill the foreground with, say, Helxine Soleiroli, Veronica canescens, or some tiny Alpine, with, perhaps, to left or right, nestling under the rock, a tuft of Saxifraga burseriana Gloria. And there-let him try the experiment-in a yard or so, he will have a lovely, perfect picture, set up by his own skill, at the cost of half-a-crown or so. And he will not be the creator of that beauty, nor will the stones, nor I that preach. The little shrub will be the keynote of the whole. Oh, but pity fights in me with anger when people lament to me, "We can do so little because our garden is so small. It is all very well for you, with plenty of room, but what can one do with a miserable little bed like ours?' O fortunati, sua si bona norint! But a little garden, the littler the better, is your richest chance of happiness and success! Far, far happier, far far easier to deal, as I have said, and say again, and shall shortly shout if these complaints continue, to have a minute compact plot of loveliness to scheme and deal with, than, like hapless me, a great unwieldy tract of stone, necessary for the multitude of my plants, but, thanks to walls and houses and such jars, incapable of being lugged into any real coherent picture of beautiful design and proportion.

If I have not yet said much of deciduous shrubs, it is because I cannot find much place for them in the rockgarden. The rock-garden, it seems to me, imperiously demands permanence of its inmates. Especially do you require vegetation that will fill the dark long void of winter. Therefore all deciduous shrubs are best banished, in my view, to the outskirts and upper reaches of the 
rock-garden. If your space is small, exclude them altogether, would be my precept; otherwise a bank of Japanese Maples may be allowed in the middle distance, but very great care must always be taken, whatever deciduous shrubs you employ, and wherever you plant them, absolutely to ignore them in the permanent scheme of the garden, to place no reliance on them as features in the design, no matter how lovely they may be while in flower. Nevertheless the fact of their loveliness in flower introduces a complicating factor. You cannot do without them; and yet, for three-quarters of the year you have to be doing without them. And thus $I$ arrive at my conclusion; they must be so cunningly placed that while in flower they strike forcibly, proportionately on the eye; and yet, when out of flower, usurp no prominent place with their barrenness and decay, but fall naturally into the background of the picture. And thus all points in the foreground must be closed against deciduous shrubs. 'They must alternate, up at the back, with evergreens, so that the fall of their blossom means no loss. And, as salient features in the scheme of the rock-garden, they have no possibilities, and must resolutely be refused.

There is one exception, though, to this rule. And I make it with reference to a thing which is less a shrub, indeed, than incarnate beauty itself. Paeonia Moutan can never be out of place on the rock-work (granted space, of course). And yet the Tree-Paeony blooms for but a short while, is leggy and gawky through the winter, leaden and dull through the autumn. But, during the flaring hours of its glory, it so holds the garden spellbound that no sacrifice is too heavy to make for its presence. I speak by book. Our masters, the Chinese, allow to Paeonia Moutan a supremacy in the rock-garden which they concede to no other flower. Remember how its beauty is made to crown the horror of that brilliant, 
memorable horror, 'Les Jardin des Supplices.' And, where they, Lords of the World in matters of art, permit the advantages of the blossom to outweigh all the disadvantages of the plant, we need not be ashamed or afraid to follow their example.

They have even, with their deep skill, trained the growth to their wish; on how many old plates of Famille rose or Famille verte will you not see the gorgeous peony, ancient, gnarled, and bossy in growth, flaunting the ardent satin of its flowers from some fretted hollowed rock of a Chinese composition? Perhaps we may never hope so to dominate the Tree-Paeony; remains the untutored loveliness of its bloom for us to enjoy. And so, if your space be large enough, surrender one rich corner against a cliff for one great specimen of Moutan. Around and underneath plant Helleborus Niger to fill the autumn, and perhaps daffodils for the early hours of the spring. And so, in flowering time, you will understand the Japanese sacred passion for beauty which impels a whole nation to make pilgrimage, in due season, to Iris Kaempferi at Horikiri, to the Cherries at Mukojima, to Wistaria multijuga at Kameido, to Paeonia Moutan at Daikonshima-there to spend whole hours and days in adoration, writing little psalms of praise and worship to the flowers.

But, remember, only the Japanese and Chinese 'TreePaeony can claim the true Japanese ecstasy of affection. Where the West has touched the products of the East a disastrous degradation has resulted; and Europe now swarms with truly horrible European Tree-Paeonieslumpish, double, semi-double, in tones of washy lilac and magenta. Of these Western creations let us hear no more; away with all the Mrs. Erasmus Potters, the Madame Hector de Telle-Quelles, the Frau Oberhofgaerterin Schlagenbuschenheims. What can you expect of creatures named like this? The Tree-Paeony of the 
East is a loose arrogant splendour; the flowers are vast, satiny in texture and sheen, sometimes torn and fringed at the edges, sometimes double, sometimes single-but always of the most imperious yet well-bred loveliness, in every pure shade of colour, from the white snows of Fuji at dawn, through faintest shades of pearl and pale rose to the growing ardours of coral, salmon, scarlet, vermilion, sanguine; and so on, into the deep tones of crimson, claret, and a maroon that deepens almost to black. All these marvels of gorgeousness did I mark down and collect when I was in Japan, and now, through June, the rows of Japanese Tree-Paeonies make my garden a blaze of bewildering colour.

About the culture of the Tree-Paeony, too, much vain nonsense has been talked, and many people are deterred from the culture of a most magnificent happiness by purely visionary terrors. Paeonia Moutan is absolutely hardy, in the first place, hardy beyond cavil, absolutely resistent to our climate. The only safeguard which can help the plant, and which is really by no means essential, is that it should not be put (in dangerous districts) in such a position as to encourage premature growth which may be nipped by a late frost. But as a matter of fact, in my damp perilous corner of West Yorkshire, where late frosts are almost a certainty, I have never had any difficulty or any sort of disaster with all my hundreds of Tree-Paeonies, planted as they are in every sort of situation and aspect. The only advice I should give would be to plant them in cool and shady places. Not only does this keep back young growth (Paeonia Moutan is a very early starter), but it also brings out the full brilliancy of the flowers, which against a cool background shine with a dazzling refulgence which they can barely attain in the full glare of the sun, against the uncompromising background of a wall. Too often, too often is a sunny wall made the 
background to Paeonia Moutan. Here the European Tree-Paeonies, and even the Orientals, may thrive and be glorious; but they will be far more congruous and beautiful against a mossy rock or some quiet curtain of leaves. For green (I wish this were as generally realised as it is generally ignored) is a far more enhancing background than glare. Some of the commoner Michaelmas Daisies, leaden, dull, and utterly boring in the border, become perfectly beautiful, lucent, clear, and purely blue when planted out in the grass. And beyond this, the only requirement of the Tree-Paeony is repeated heavy feeding with the richest of manure-incongruous as such treatment may seem for such sylph-sounding creatures as Hope of Glory, Moonfoam, Clouds at Dawn, Fire-Flash, Leaping Lion, Bridal Dream.

Another shrub for the big rock-garden whose treatment I believe, on no authority of mine, to be generally mistaken, is the great Californian Tree-Poppy, not altogether unlike Paeonia Moutan, white-flowered, on a smaller, frailer, freer scale of flower, and a larger, lusher scale of growth. Romneya Coulteri is usually cultivated under a wall. It is so that I have always grown it, with the most persistent disappointment. Every year it came up ranker and more rank, and, in late summer, made abundance of buds, which developed sporadically into flower one at a time, producing no effect, and passing away frustrate, before the advance of autumn frosts. Nothing I could do seemed of any avail. I protected the old wood, and I cut it off-with equal futility. Romneya Coulteri was written down a failure. It was only last winter, when the key was given me, that I remembered my first impression of the plant as a rounded, openground bush in Mr. Woodall's garden at Scarborough, white with its huge filmy blossoms from crown to base. And now information received leads me to understand 
that Romneya Coulteri is an open-ground shrub, that it becomes bored and lazy if grown under a wall, that only in an unprotected place, swept by every wind and frost that befalls, will the great Californian Poppy show the floriferousness of its true character. Add to this a dressing of lime rubble, and you will probably be picking blooms of Romneya from June to November. And those blooms are worth the winning-large and frail, built of the thinnest crumpled white silk, almost diaphanous, like the strange ghostly confections in a woman's summer hat, with a central boss of golden stamens, and a warm little delicate fragrance like that of the Rose Maréchale Niel. In hopes of such a harvest my Romneyas are all to move out into the open, and abundance of their root-cuttings shall be struck, too, in spring, to repeat the experiment in every situation.

Of small deciduous shrubs for the rock-garden there are many; but few are fitted for a limited space. Cornus and Rubus each give minute species. Cornus suecica, our own rare native, I have never grown, nurseries always sending me Cornus canadensis instead. This is a very attractive tiny thing, which I myself have collected abundantly in the Canadian Rockies. It grows about six inches high, and runs freely in any quiet peaty place on the rock-work. The whorled leaves are ovate, darkgreen; the microscopic flowers look like the crowded stamens to an apparent flower made up of four big, snowwhite bracts. Suecica is similar, but not nearly so attractive, I believe. The two Brambles, delightful for any peaty ledge or nook (the spiny, leafless-looking Rubus australis is not hardy), are Rubus arcticus and Rubus pedatus - the first an upright little shrub of six or eight inches, with flowers of bright carmine-which are brighter still in the fruit-bearing variety, arcticus fecundus; the second a very pretty, palmate-leaved trailer, with large white 
flowers, which hails from North America. And the last of these minute Brambles-which it seems almost an insult to one's intelligence to think of as shrubs-is our own native, Rubus Chamaemorus. The Cloudberry dwells in great colonies on all the high moors of Northern England, Scotland and Scandinavia, hardly descending or bearing any descent below two thousand feet. It abounds on the saddle of Ingleborough, and again immediately below the precipitous western face, but I have never yet made any success with it in my garden, short as it must find the journey thither. It has lived several seasons, indeed, but rarely flowered, and never fruited. And the fruit is its great attraction. The plant is about six inches in height, with two or three rounded leaves, Black-currant-like, thick and solid. The big white flower stands solitary at the top of the stem, staring upwards. And there, in time, forms the fruit, ripening about August-an enormous raspberry of fewer and larger carpels, russet-red at first, then ripening to a soft, golden amber-when its taste has the sparkling acidity of the Pomegranate. Unfortunately the grouse so share my love for its juices that it is very rarely, on Ingleborough, that I have enjoyed the Cloudberry; and I have never been permitted that Enough which is so fallaciously described as being as good as a feast.

Of big brambles there are many-vast invasive weeds for the most part, which must be banned by all who do not possess unlimited acreage of wilderness. Rubus leucodermis is handsome-tall, with white-washed stems; the new flagelliformis has whip-cord shoots of eight or ten feet; hypargyrus I only have in seedlings; nutkanus and biflorus are magnificent plants for the wild garden, but cannot be allowed in any choice territory. They are much alike, tall, dense growers, fearfully rampant, with big, green currant-like leaves, and very big flowers, which 
in nutkanus are rose-red, and in biflorus, pure white. But they are such prolific spreading pests that $I$ have had to banish both-and banish them, too, not merely to the wilderness-garden, but out into the wild wood itself, to sink or swim as they choose.

Last of the Brambles, though, comes a real jewel, in Rubus deliciosus. The epithet, so often, so direly misleading, is in this case justified up to the hilt. Rubus deliciosus is very beautiful indeed-a middle-sized, woody, deciduous shrub, producing long arching shoots, which, in June, are weighed down, all along their line, by enormous brilliant flowers of the purest white, like some strange variety of wild-rose, only more floriferous than the most generous of roses. Rubus deliciosus thrives perfectly in any fair soil and situation, and is a frail shrub of the greatest possible merit for the rock-garden, quite admissible to the background even where space is limited.

Since we are now in the cousinhood of Rosa, we may as well continue with Spiraea and Potentilla. Most of the Spiraeas and all the herbaceous species must be dealt of with the greater and lesser bog-plants; but of the shrubby kinds, while most-Ariaefolia, mongolica, arguta, Margaritae, Douglasi, Aitchisoni-are magnificent shrubs far too large for all but the largest rock-gardens, Bumalda and crispifolia are small enough to be made welcome. Bumalda is the larger, and has heads of big pink flowers-ruby-red in the form Antony Waterer; crispifolia is neater and smaller, with rusty-looking little Hower-heads, and screwed-up curly dark leaves. They have a caterpillared look which repels me, and I find a repellent chalky tone too in the pinks of Bumalda and Antony Waterer (indeed in almost all the pink Spiraeas). So that, without enthusiasm, I pass on to a front-rank rockgarden treasure in the very rare and little-known Spiraea Hacquetti (very close, if not identical with S. decumbens) 
from the Dolomites. Hacquetti is as easy-tempered in good soil anywhere on the rock-work as a weed, and resembles a minute spreading arguta not three inches high, with heads and garlands of little snow-white flowers. It is a neat, tidy little grower, which all who possess it should set to work propagating from cuttings, the beauty and value of it being pre-eminent. I prefer it, so far, to all I have yet seen of the newer, tinier Spiraea caespitosa, which is nearly as dwarf as a moss and, I think, less inspiring.

As for the Reine des Près, Spiraea Aruncus, this great herbaceous species is usually grown as a border plant, in dense clumps. Grown thus, in huge masses, though it is glorious in flowering time with its sheaves and plumes of creamy bloom, it gives you no idea of its wonderful beauty when occurring on some barren wet rock in one single crown, carrying three, perhaps, of its graceful arching leaves, and one feather of flower on a four-foot stem. It was thus that I first saw it years ago in the awful gloom of the Georges de Trient, with three hundred sheer feet of damp cliff on either hand, interlapping as they mounted, to intercept the few faint ghostly rays of daylight that filtered down into that gleaming den of darkness. The air was eternally cold with twilight and the spume of a roaring torrent, but, wherever plant could find lodgment in the crannies, there Spiraea Aruncus had sown itself, and its isolated spires of whiteness wavered like phantoms in the chill gloaming. So, in my garden, Aruncus, from two huge clumps in the borders above, has sown itself here and there in tiny crevices that admit no increase in the size or number of its crowns, and thus, in single spikes, the plant has a rare grace and charm. I am trying, too, following this delightful hint, to make it germinate over the sixty feet or so of creviced limestone precipice that overhangs the lake at Ingleborough where 
I am establishing a wild cliff-garden, which, when fairly started, will be a wonderful sight of natural beauty.

Of the Potentillas there are two or three that are genuine shrubs, and admirably fitted for the rock-garden. Of front-rank among these comes our own native, Potentilla fruticosa, a plant curiously rare, and yet curiously abundant where it occurs. 'Thus you will find it above the High Force in Teesdale, that gardener's Paradise, where the botanist grows crazy for Viola arenaria and Arenaria uliginosa, and the gardener's bones are melted within him by the ecstasy of Gentiana verna and spreading miles of purple pansy. On either side the river, in the sand, grows Potentilla fruticosa, a close, woody, wiry shrub of two to three-foot height, covered all over with abundance of big, brilliant yellow flowers. This treasure is invaluable for any garden, and absolutely easy in any soil. The only thing it requires is to be cut over, hard, if ever it shows signs of becoming leggy. It will break out anew from below, and re-form into a compact bush. Very similar to this again is Potentilla floribunda-indeed hardly, to me, distinguishable, unless its flowers are a little smaller. $P$. Salesozii is a newcomer, reported to have whitish flowers. So far I only find it a small shrub of rather ugly leaf and growth. The sulphur-blooming dwarf Potentilla Friedrichseni I have not yet tried, though, on the whole, I hear it well reported of. But the triumph of the race is Potentilla nitida-though I don't know if I can fairly call this a shrub, seeing that its height is only about two inches at the very most. Potentilla vitida lives in the Alps of 'Tyrol and North Italy, in the higher, sunny moraine- and débris-slopes - a minute, woody trailer, with cloverish leaves, of a pure grey, brilliantly silver on the reverse, and very large flowers of a rich cherry pink, differing in depth of colour in different plants. If the ordinary rosy type were not so beautiful, the snowy- 
bloomed nitida alba, pure white against the pure silver of the foliage, would be one of the loveliest little plants of the rock-garden. All forms of Potentilla nitida, too, grow with the most perfect ease and good humour in any fair soil, in any sunny spot, and multiply from cuttings like any bedding Viola. The plant's only fault, and one to be very carefully guarded against, is a tendency to go to sleep in rich soil, and prove to be painfully shy about flowering. This, however, can be remedied by planting it in rubble and dust. I have not yet tried it in the Moraine-garden, but it will probably succeed there and bloom abundantly. Very similar, too, in habit is the rare newcomer, apennina, of which my one plant looks a twin of nitida, though I believe the flowers are white.

Over such diverse-seeming species as Potentilla, Rubus and Spiraea does Rosa extend the shelter of its great name, and now, in due course, we come to deal with the roses. For the most part these are middling shrubs (I shall scarcely talk of the garden kinds, the doubles, and hybrids), very welcome on the upper banks of the rockgarden. But the first in merit for big and little territories alike is Rosa alpina, a small, neat, dense shrub, finely thorny, with abundant lovely flowers of a deep velvety crimson, and sweetly, richly fragrant beyond any rose I know. On a warm day the hot, deep sweetness of this rose's scent is something almost vertiginous. Then, when the flowers are fallen, succeed long scarlet heps that prolong the charm of the plant till far into the autumn. Rosa alpina is so easy-going and sturdy a species that it will fend freely for itself if cast out unprotected in the woods (indeed I wonder that it has never appeared as a native), and, at the same time, it is so concise and modest in growth that no one need be afraid to admit it into even the smallest of gardens. Similar in size, but much 
less in charm-to my taste-are Rosa lucida, and Rosa Malyi.

Of the greater roses, any big garden will be glad of such Ramblers as Dorothy Perkins and Lady Gay, of the Wichuraiana hybrids-especially Gardenia, Jersey Beauty, and dreamlike René André; of such huge wild species as the fiercely thorny, crimson-blossomed acicularis, of the beautiful four-petalled sericea, of ferruginea with its grey and purple foliage and its large pink flowers, of caroliniana, smaller in growth and delighting in very wet ground, of rugosa and lovely new yesoensis, of the brilliant Austrian briars, and above all, in favoured corners, of those fanatic sun-lovers, berberidifolia, sulfurea and bracteata. Alas, that lovely little shrub, Rosa berberidifolia, with its golden blooms basally spotted with chocolate, is of no use to my damp climate; and bracteata, the glorious Camellia-rose, with its solid shining leaves and its immense snowy blooms, perpetually lingers on the edge of death, blossoming indeed, but late, and always cowering earthwards in the winter. Yet it is not cold that is fatal to these sun-craving roses, so much as the absence of ripening sun in summer. I have actually kept Rosa gigantea alive in the open for two successive winters unprotected. As for Rosa bracteata, its variety Anemone has all the beauty of the type, if not more, with twice the general usefulness and trustworthiness. Rosa bracteata (or sinica) Anemone seems to be a robust sport from the parent, differing in its far greater vigour and resisting power, as well as in the colour of its enormous saucer-like blossoms, which are of a particularly entrancing soft pink.

All these roses, of course, need no special help beyond fair or rich soil. As for Rosa gigantea, I believe no one has ever flowered this Lord of Roses in the open in England-nor, I fear, will any one succeed in doing so. 
This Burmese giant of his race is a tremendous tropical Liane, whose trunk is girthed like a man; his flowers, nearly a foot across, if not more, are, says report, of a gentle yellow. He has flowered indoors, I believe, at Syon, and rumour whispers of a marvellous hybrid that he has made out of doors in favoured Portugal, with Gloire de Dijon. Shall we ever be privileged to see, or fortunate in acclimatising, this portentous offspring of two parents so august? As for the other large roses, arkansana is only a young seedling with me, and seems, as a matter of fact, inclined to be small; but $I$ reserve a corner for graceful great Rosa microcarpa, carrying enormous arching boughs bent down by tremendous heads of little white flowers, that in autumn are succeeded by showers of scarlet fruit, very delicate and effective. The same effect, only lovelier, do I expect from my latest novelty, the coral-clustered Rosa yesoensis.

Of course, in big gardens, the great cluster-roses all make pictures of unrivalled effect. Never shall I forget, high in the mountains of Japan, one blazing day in summer, how I came on Rosa polyantha making a blinding snowstorm above a little trickling beck in a nook of the jungle. Even so, over craggy boulders, might one shower it in England-or any of the roamers, indeed, such as the exquisite 'Blush Rambler.'

And here, to close my roses, I must put in a friendly word for my own ignored countryman, the rare and charming Rosa villosa. Rosa villosa, though I call it rare, is, as a matter of fact, almost as common in the north of England as Rosa canina. But it never wanders southward; its range is limited, and its charm is far greater. It makes a much smaller, frailer bush than the Dog-rose, admirable in size for the rock-garden. The foliage is faintly grey with fine pubescence, the big flowers are of a blazing crimson as they open, 
and, even at their fullest, are many shades darker and more brilliant than the pale blooms of canina. To my mind Rosa villosa, in point of colour, is nearer to alpina than to the Dog-rose; there are many shrubs, many roses in our gardens, of less merit and beauty than this neglected native. There is also an attractive Albino form of villosa, but this cannot really challenge the beauty of the type.

Passing now from the roses, no gardener fortunate enough to possess a cliff of his own, will ignore the great Wistaria of the East. With memories of Wistaria multijuga my heart is full. In the Garden of Asia stands recorded the beauty of the wild plant as I saw it among the thousand islets of Matsushima, trailing down those violet garlands over each fretted fantastic cliff of sandstone, blending its cool grey softness with the golden flare of Azalea mollis, while the still green water, swelling lazily against the rocks, sent back in shifting catches of colour the image of that riotous loveliness. Or Wistaria multijuga again, at Kameido - arcades and trellises of it everywhere, built out on long partitioned galleries over the waters of the temple lake, while the worshippers, having each engaged his partition for the day, sit at peace beneath the four-foot plumes of pale purple, and adore the misty loveliness of the canopy overhead. Do you want four-foot plumes of Wistaria multijuga in England? Then give it all the sun you can and all the richest food. It is far from being a difficult plant to deal with, much less a hopeless one; and remember always that the ordinary Wistaria sinensis, even at her best, is but a poor pallid widow compared with the bridal opulence of Wistaria multijuga.

Now that my heart is back in far Japan, it becomes impossible for me any longer to keep silence on the other 
Japanese treasures that I nurse in my rock-garden. And nothing-not even if they grew to the size of St. Paul'sshould deprive me of the Japanese Cherries, single and double, rosy, white, and yellow (though the Yellow Cherry, indeed, is more alluring in idea than in reality, being of a faint, greenish-sulphur shade, which is very effective on a big, well-flowered tree, but mean and depressing on a small, young specimen).

Of the other Cherries, the dwarf rare Cerasus prostrata, is best for the rock-garden, while of the Plums, glorious Mumé is, I begin to fear, of uncertain flowering in my climate, like several of the Pyruses, which perhaps I don't treat properly, especially Pyrus spectabilis, the most beautiful of all, of which young plants from Japan blossomed last season till their frail branches creaked beneath their burden of rose and ruby snow-and this year are nothing but shoot and leafage. Perhaps pruning will help the Japanese Plum. Or does it require more summer ripening? In Japan it makes so bewildering a spectacle of beauty through grey, icy March, that one would spare no pains to have it in England doing likewise, if possible. The two giant plants in my shrubbery are two specimens I bought for a shilling each at a night-fair in Tokio. They lived in my house for a fortnight-sheer indistinguishable balls of white and pink. Now they have shot up and about like Jack's beanstalk, waving enormous whip-cord shoots. And they each average perhaps five blooms a year.

The same trouble attends my culture of Chimonanthus fragrans, that most heavenly-scented of all heavenscented flowers. Long had I known of it, and never seen it, till one day I walked in a certain lovely garden on the Genoese Riviera. And there, in a cold, shaded corner, chill with January's frost in unsunned aspects, I was transplanted to heaven on the wings of an ineffable 
fragrance. Of course it was Chimonunthus fragrans-a great bush of it, clothed all over with those dull pale, waxy flowers, of which one is enough to fill a whole big house with bliss. But though I have great bushes now at home-bushes that shoot and thrive and ramp-yet I have not yet had even that one flower annually for which I would alınost compound. Not only, by the way, are the blossoms of Chimonanthus thus scented, but if ever any one has noticed the curious musty sweetness that hangs characteristically about everything imported from Japan, and has wondered what the cause may be, let me advise him to pick off and pulverise some dry, dead twig of the Chimonanthus. Immediately, and with no money spent on train or steamer, he will find himself standing in the avenue that leads up to the temple of $K$ 'annon Bodhisat' at Asak'sa, in the full roaring tide of Japanese life. So poignant, so instant is the call of a fragrance.

Another Japanese shrub of high rank for the rockgarden (for the Calycanthus-cousins of Chimonanthus awake no zeal in me, nor will I linger over half-hardy Serissa foetida, whose pretty little blue stars do most unutterably stink) is the heavenly Bamboo, Nandina domestica, which unites the delicate leafage of an immense Vancouveria or Spiraea with loose, lovely showers of white or scarlet berries, which Europeans in the East use at Christmas as a substitute for Holly. Nandina is a very holy plant in the East; it is always planted by every verandah, at the place where the bowl stands on its stoop for the washing of hands. And in England, with me, despite sad prophecies, I have found Nandina perfectly easy and perfectly hardy. It loses much of its leafage in winter (hence I class it here as deciduous), but never fails to continue thriving robustly. Of course it does not fruit, and never will fruit, but the beauty of the 'fronds' is so conspicuous as to set it in the front 
rank of small shrubs for the rock-garden. Especially is it lovely when, with spring, the young green of the dawning leaves contrasts with the russet and ruby of last year's persisting sprays.

But perhaps, of all shrubs introduced in the last twenty years, Buddleia variabilis, in its varieties, takes the first place. Almost tropically luxuriant is this wonderful great ragged bush, which is hardier and more easy-going and more rampant than many a Lilac or Syringa (not to mention, too, that it blooms in August, when all other flowering shrubs are long since over and done with). Almost tropically gorgeous, too, with its countless foxbrush spikes of dense violet flowers, golden-eyed and sweetly-scented (which last so much longer if only they can be protected from the ravages of bees). Buddleia variabilis requires hard pruning, and its flowers do not stand in water, otherwise the plant has no fault of any kind, for any position in the whole garden. There is now a prostrate form of it, too, which I am trying this year. If it proves as magnificent as its description, this should be as invaluable for the rock-garden as type variabilis is for the garden in general. Globosa I have not yet grown, it being too large; and the almost dizzily sweet asiatica is a cold greenhouse plant. Remains Buddleia Colvillei, reported as a miracle of beauty and difficulty, delicate, miffy, shy,-but glorious, in its native Himâlyas, with showers of big rosy trumpets over soft grey leaves. I foolishly and desperately resolved last year that I would have a try at Buddleia Colvillei. I ordered a plant which, when it arrived, turned out to be at least three inches high. In utmost trepidation and scorn of my own rashness, I planted it out none the less, under a wall, in good soil. Immediately the most fearful storms, sleets, and frosts swept down across the north, followed by a blighting drought accompanied by unceas- 


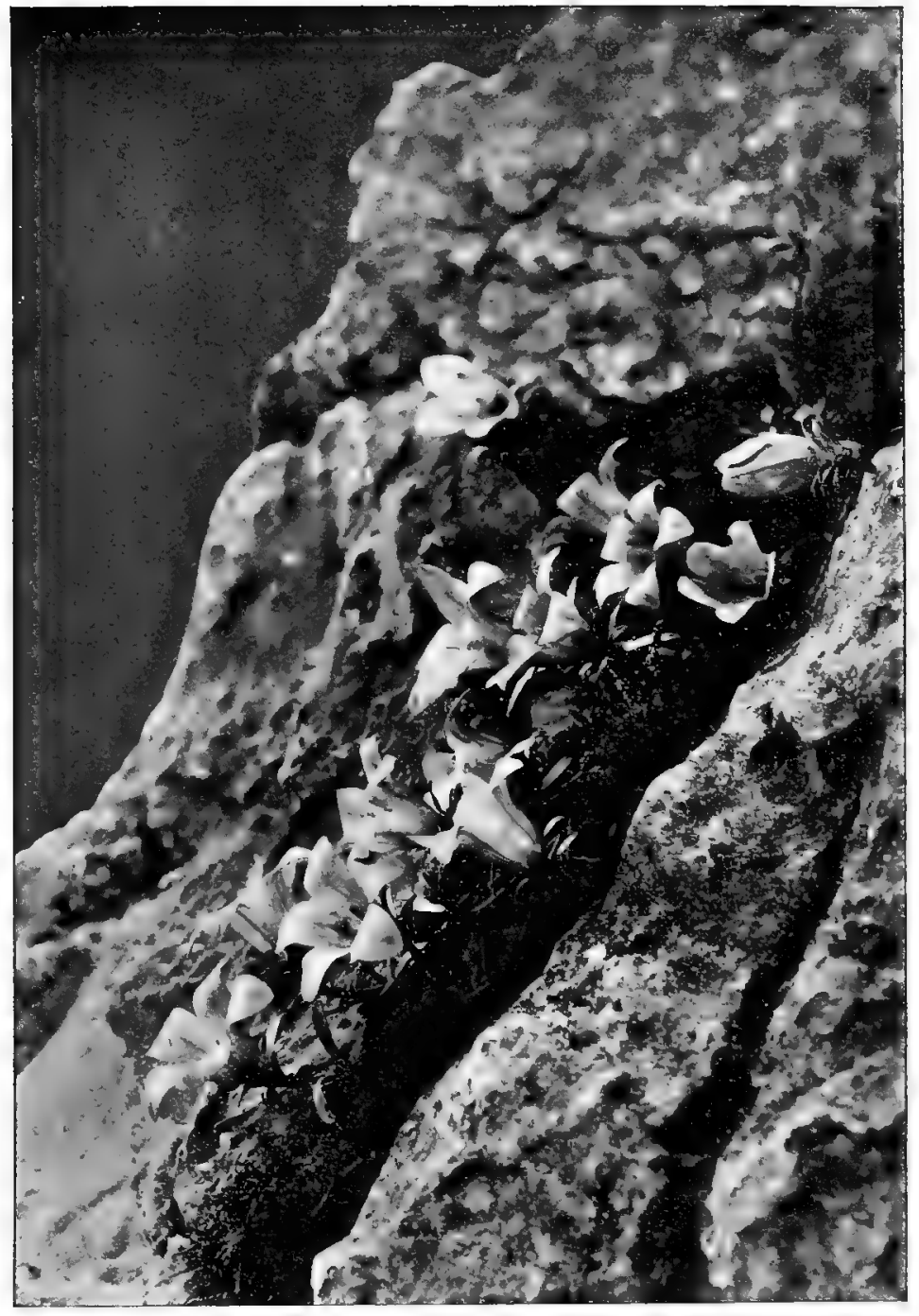

EDRAIANTHUS SERPYLlifOLIUS MAJOR. 

ing cast winds. I said good-bye, in my heart, to Buddleia Colvillei. But Buddleia Colvillei was not to be got rid of. It grew all through that weather, as I have rarely seen a plant grow; and by autumn it was three feet across, bushy and robust, and about two feet high. I sheltered it with gorse as our last dreadful winter grew on, but, so far as I can see, Buddleia Colvillei, though cut back, seems inclined to break again, more vigorous than ever, regardless of inclement seasons. When or whether it will flower remains, of course, a different question.

Now comes the last great race of deciduous shrubs (for Azalea is to be lumped, nowadays, with Rhododendron) for the rock-garden. The one crime of which all the Magnolias except summer-blooming glauca are guilty, is of flowering within reach of late frosts which reduce their pure and waxy fragrance to a mass of brown feculent rottenness. Otherwise they are all rivals in beauty and charm. Glorious Yulan and its kin are perhaps too large for small gardens; even Kobus and Watsoni develop into trees. But surely they are so delicious that every garden must allow them room to the last possible moment. All are easy, all are fragrant, all are magnificently, regally beautiful. I grow Kobus, Watsoni, glauca, rustica rubra, Yulan, obovata, hypoleuca (the great forest-Magnolia of the Japanese Alps), stellata, tripetala, and the very rare salicifolia. Stellata, of course, is the jewel of jewels for the rock-garden-quite a small, close shrub, three or four feet in height, with myriads of pearly goblets that open out into stars. Rustica rubra is a variety of uncertain origin, akin to soulangeana, with big chalices of soft deep rose. (Alas, that the supreme beauty of all, Magnolia Campbelliae, is of no use over the greater part of England, and even in favoured corners of Ireland and the south only deigns to show its huge coralline cups occasionally, 
in certain seasons, between tracts of barren years.) Watsoni is a straggler, akin to parviflora, but bigger and far hardier, with round snow-white balls, whose central cone is ringed in by a circle of vivid scarlet anthers. Glauca is a small American shrub, loving wet places, and producing its creamy, fragrant blossoms in July and August. It has, so far, though a success, been less of a joy to me than Kobus, stellata, and Watsoni, which all do wonders. Kobus is my particular joy. It is an astonishingly dense, vigorous shrub, rapidly growing on into a tree; its flowers are not enormous, nor very solid, but are borne in the most splendid abundance when the tree gets on in years. It is a thing of obviously first-class merit, and I wonder that it has not been more widely proclaimed. As for salicifolia, it is due to have remarkable purity and brilliance and beauty. So far, though, my healthy plants are but babies, and will not flower for some years. All I can say at present is that every part of the plantleaves, stem, and bark-are deliciously fragrant. And, to conclude, any light cool soil, peaty or not, will suit all these Magnolias.

Remains now only the race of Knotweeds, to which duty, rather than affection, bids me concede a place in my gardens. I make an exception, however, in favour of Polygonum vaccinifolium, which is a rock-garden plant of very high value, as all who grow it can bear witnessa trailing, rock-hugging mat of woody, small-leafed branches which in autumn are covered with an inexhaustible profusion of erect little rosy spikes four inches high or so. Its generosity is no less valuable than its time of blooming, and its exemplary ease and good temper no less conspicuous than either. It grows eagerly in almost any soil, in any open aspect, and multiplies readily when pulled to pieces. As small as this is the linear-leaved $P$. Emodi, which, however, does not spread so fast or so 
far, but makes a spider's web of growth, from which come up the heads of deep pink flowers. This is a rare, new species, but has no charm or preciousness to compare with vaccinifolium. The equally rare $P$. sphaerostachyon - though, by the way, this is frankly herbaceous, not a shrub at all-is, to my taste, downright ugly-an undistinguished little plant eight inches high or more, too leafy for its dull globes of rosy blossom. Half the size of this, to continue my divagation, is our own rare native, $P$. riviparum, very similar, but much prettier, with spikes of pearl-white flowers that produce their young ones ready born. It is reported from our alpine meadows to the east of Ingleborough, and I have found it abundantly in upper Teesdale. In the garden it thrives quite happily almost anywhere, even if it prove of no very solid permanence.

Returning to the greater, shrubby Knotweeds, they are, for the most part, only fitted for the largest, wildest garden, so commanding is their stature, so invasive and violent their development. Polygonum saghalinense is the most really tropical of all our cultivated plants-and this though it hails from so bleak and untropical a corner of the world as the undesirable convict island which is the contended bone between Russia and Japan. It rises to twelve feet or more, in single arching boughs, clothed with great leaves like magnified Hazel. It dies clean down in winter, and runs vehemently about underground, so that, in rich favourable, sheltered glades (in which alone it can attain its fair development) it becomes the most stately of weeds. Rather smaller in leaf, size, and habit, is $\boldsymbol{P}$. cuspidatum, which, instead of the single sprays, sends up abundance of boughs from a yearlythickening central crown. This, no less easy and hardy than saghalinense, is perhaps a safer plant to admit within sight of the rock-garden-though in such choice 
territory the only Polygonum which must always be indispensable is vaccinifolium. Oxyphyllum is still smaller than cuspidatum, with a profusion of snowy plumes in autumn; and a climber of great merit is baldschuanicum, which makes curtains of greenery in no time over a bush or stump, and then, before it dies down, glorifies October with a cloud of white.

The Fuchsias, brilliant race, do not, of course, do very much for me in my damp, ill-wintered climate. The little hybrid, Bouquet, thrives well, and Riccartoni persists. And these are of high value for the rock-garden, particularly Bouquet-a tiny, tidy little herbaceous shrub, if one may use so paradoxical a term, which always keeps its position and proportion. But in gardens where the sun is lord, many more of the Fuchsias may be used. I shall never forget my first realisation of what a hardy Fuchsia means. It was on the western coast of Ireland. Beneath the august cone of Croagh Patrick lies a tiny little ruined abbey, buried almost to its eaves in the encroaching sands of the shore. Far away beyond, a great square island, blue and very pale, stands up on the uttermost rim of the great pale sea. And, in this remote corner of peace and death, Fuchsia Riccartoni has made itself a beautiful shroud for the dead shrine. Everywhere, amid the walls and ruins and sand-banks, wave its long slender arms, and a million scarlet trumpets in the sunlight dance up and down with every faint cool breath that hovers landwards over the face of the water. Only their incessant flicker disturbs the immemorial tranquillity which holds this heart of long-dead holy activities, as it lies buried in the shifting sand, embalmed in the golden tranquillity of a burning summer afternoon. And, looking back in memory, I scorn the specific. To Riccartoni, far down in the years, I refuse to swear; Fuchsia is all that matters. And, as for tiny trailing Fuchsia procumbens, for the 


\section{OF SHRUBS AND THEIR PLACING 25}

rock-garden, with its dull wee flowers and huge scarlet berries, Mr. Eden Phillpotts may luxuriate in its hardiness, but with me it is a delicacy to be nurtured (without ecstasy) in the vinery. Even on his promise I can hardly dare believe that it will ever prove winter-hard with us. 


\section{CHA PTER II \\ Df 乌hrubg, mogtlp Épergteen}

Mostux, I head this chapter, because in the great evergreen races there occur deciduous species, and vice versa. And it would be jerky and pedantic to keep my reader hopping backwards and forwards from chapter to chapter in order to join up the disconnected ranks of Magnolia or Azalea. Nor will I make apology for using this latter name. It is hard that, where botany swarms with ugly names, hideous, hard, teutonic, latinised Russ and bastard Greek, a name so simple, gracious and euphonious as Azalea should be torn from us, and we be left with no refuge but the lumbering if orotund syllables of Rhododendron. Therefore, since no one can be in doubt what is meant by Azalea, I will continue in the old, superseded ways. If all races were so unmeaningly, so sweetly named, our gardens would be happier, our labels less deforming. But we are at the mercy of chance, it seems, in these matters. It was mere luck that the eponymous hero of the Yulans was able, being a M. Magnol, to supply so appropriate and fragrant a generic name as Magnolia. On such a frail coincidence does the question of nomenclature depend. Suppose the Magnolias were Smithias, Von Borkias, Mulliganias? And it is mere luck that they aren't. If their discoverer had had his life saved by the Mulligan (of Ballymulligan), and had nourished due gratitude, Heaven knows what might have 
happened! Nothing could well have saved us from Mulligania. Which leads me to a despairing proposition. Fitting, fair, and honourable it is (as Sir John Hooker points out) that great gardeners, explorers, lovers of these delights, should be commemorated and honoured in the names of flowers. But Sir John slides over the great difficulty of the question: we are not all Magnols, and since no man has power over his own name, and since a lovely, floral soul may be clothed in such syllables as Smee or O'Higgins, why not alter our system of nomenclature, and avoid the danger of having to damn a plant eternally under the style and title of O'Higginsia or Smeea? There is actually-think of it!-a rock-garden plant called Boehninghausenia. On the same principle, too, mountains great, divine and glorious, must be saved from the indignity of being labelled Mount Baker or Mount Bullock Workman. My plan would be to adopt the Japanese, the savage principle, of naming for fitness ; and, when a plant comes up for name, my compliment to the great horticulturist would take the form, not of asking him or her to stand god-parent to a possible BullockWorkmannia Fanniae, but of giving him the right to choose the novelty's name himself. Personally I should value this right far more than the ascription of a species under my own syllables, and take more pleasure in registering Saxifraga Gloria than Saxifraga Farreri.

Azalea, then, leads off with Azalea procumbens, which, to be correct, ought to be spoken of rather as Loiseleuria procumbens. The Alpine Azalea is the strangest and, I think, with the exception of Pyxidanthera and Andromeda hypnoeides, the smallest of all northern shrubs. It is as flat as any lichen or any starved mat of thyme. Indeed, but that its tiny leaves are leathery, bright green and glossy, the plant is not unlike a thin tangle of wild thyme. On this appear, in spring, abundant flowers, gazing upwards 
into the eye of day, comparatively enormous little cups, waxy, coral-pink, delightful. You will find the Alpine Azalea all over the higher ranges of Scotland, and everywhere in the upper Alps. It makes a great part in that fine, close lawn which you reach below the lowest lip of the moraines; and its frail, hard woody branches go trailing far and wide, making warp and woof for the Androsaces carnea, vitaliana and Chanaejasme, for the alpine clovers, Oxytropids and Phacas, for the gentians verna, brachyphylla and nivalis. Unfortunately it is a very difficult plant to collect, and not by any means an easy plant to grow. It is strange that a native should be perverse, but Azalea procumbens requires a good deal of care-perfect roots to start with (a sufficiently hard proviso), then a cool, open space, in light, cool peaty soil, rich with vegetable humus. At present, I believe, I have only one thriving plant, and that but small. Nor is it easy to get more. This year, however, I am trying the experiment of bringing down a quantity of the fine powdered black humus, decay of decay of decay from the very beginning of things, which is to be collected from peat-hags high on the saddle of Ingleborough. Of the chemical properties of this pulverised stuff I leave wiser heads than mine to speak; in a way the nutritive qualities of this extinct rottenness must have changed or failed. And yet it plays an incalculably great part in the life of the higher Alpine vegetation, contributing some mysterious gift essential to the well-being of such things as the arctic Andromedas, and the mountain Azalea. Possibly, though not in itself food, it provides some substitute for food-of which the truly Alpine plants are very impatient in any excessive or obvious degree-perhaps, that is, the humus acts as a subtilised nutrition inoffensive to the dainty tastes of these mountaineers, and yet satisfactory to their needs.

Of the other Azaleas my song is still sorrow. There 
are, in my limy soil-limy in spite of all the most elaborate diggings and delvings and drainings (for lime is no less difficult to exorcise than love)-only two exceptions to the general rule of sickliness among my Azaleas. Bog-haunting viscosa have I tried, fragrant with white flowers in late summer; fiery orange calendulacea, tawny sinensis, rosy apple-blossomed Vaseyi, profuse magenta-flowered amoena. And all, all are modified failures here, in the course of a year or two. One exception is the living fire of Azalea mollis, most blazing and diverse of all flameflowers. And the other, by a strange unexpected freak, is the delicate Azalea indica itself. Now Azalea indica is the ordinary greenhouse Azalea; and, when I imported a quantity from Japan, I laughed at myself for daring to plant them out in the open immediately. Not one of them in five years has ever suffered from cold or drought or lime or damp; rarely have any of them failed to produce abundance of bloom. And this though they are planted in merely ordinary garden soil, permeated with lime, and though quite unsheltered and unprotected. Some are under a wall, it is true, but the rest, among which are some of the most brilliant, stand out in the open, dead level, heavy-soiled plain of the bog-garden. And this once more encourages me to proclaim my gospel. Half-hardy plants, imported from cold districts, prove often to be as hardy as the most robust of natives. From the icebound plain of Tokio all importations of delicate species are, a fortiori, perfectly willing and able to resist the utmost rigours of our far less rigorous winters. I even have hopes that I may prove this of Nelumbium speciosum. I am importing the Holy Lotus from its most northerly limit of distribution, in the trust that thus its tubers may be victorious over our pale climate.

In point of fact, I cherish a dream that all gardeners are far too little venturesome about attempting paradoxical 
experiments. Last year I hurled out all the old greenhouse Cyclamens-huge lumping old corms-on to a light-soiled bank beneath the shelter of thickly planted deciduous honeysuckles. They all lived and continued to thrive, though the weather, for the next six weeks, was nothing short of appalling. More than a year has passed, and it looks as if some of them might yet live awhile. This, of course, is a platitude in warm Cornwall, but a paradox in frost-swept Yorkshire Alps. And such experiments cost little; one tries, perhaps, the corpora vilia of superfluous plants. And then what is the amazed joy of success! In this last autumn I threw away, in a pet, a worthless plant of Odontoglossum crispum, vexed at having overlooked it when disposing of my third-raters a week or two before. Frost was ruling at the time, and next day I regretted the cowardly brutality of my action. So I went and quested for my victim, set on making amends. And there, on the frozen grass, I found the dispotted Odontoglossum still alive and well. 'Whis changed my plans; I took it up and planted it in the rockery, in a sheltered corner, near the protecting shade of Cistus laurifolius. It was an absurd experiment, but I could not resist the temptation of trying it. Of course the poor thing ultimately died, but I solemnly declare and affirm that there, in the open, Odontoglossum crispum held out for a solid three weeks, during which time rain and tempest alternated with bitter frost, and the temperature was generally down to goodness knows where at night.

Of all evergreen flowering shrubs though, for the rockgarden, great and small, the enormous race which we call Rhododendron (exclusive of Azalea) is the most august. Here, again, I am stumped by the impossibility of eliminating lime from my soil. However, I have induced no fewer than three of the Himâlyans to thrive-though, started as tiny plants, they have not yet flowered. These 
are fulgens (this, I remember, bloomed last year, but was cut by frost), most dazzling of scarlets in the garden, luscombeanum and campylocarpum. I even induced the royally beautiful Auchlandi to survive through three unprotected winters. The latest novelty I am trying is Smirnowi, large-leaved, but reported very slow-growing, with big pink flowers. But the great Rhododendrons cannot be introduced too carefully, even too sparingly into the rock-garden. Almost invariably their growth is either rounded and lumpish, or straggling and gawky. Their leafage, too, when the brief glory of the flowers is gone, is leaden, dull and depressing. For my part, I detest and flee the vast pies and puddings of Rhododendron that prevail in all parts of England where the soil admits ponticum, catarobiense and their hybrids as almost wild plants. 'And I'm sure it's no ill-breeding,' as the classic poem has it, 'if at these repulsive pies, Our offended gorges rise.' They are terribly overdone; the blaze of them in bloom is overwhelming; for the remaining eleven months of the year they make mere humped domes of lead, gloomy, uninteresting, and undistinguished by any countervailing grace of line, form, or carriage.

It is with the smaller species that Rhododendron comes to its own in the rock-garden. And yet I must not shrink from the truth. I almost dislike the Alpenrose. In fact, I do. I have no notion why, but for this glory of the Alps I can muster no affection at all-hardly even esteem. Its growth is generally straggling, and I am not fond of the flowers. And this coldness is not due to the fact that neither ferrugineum nor hirsutum ever enjoys itself in my gardens; for I like the plants as little in full riot on the slopes of the Oberland as I do in sickly dwindling specimens on my rock-work. And so let me leave them to others. Perhaps their rather harsh colour, not chalky exactly, nor magenta, but to me mysteriously acrid and 
vulgar, influences my opinion; for I have no such prejudice against lovely $R$ hododendron racemosum. This makes a charming wee bush (and grows admirably with me) clothed with hard little ovate leaves, greyish beneath; and the abundant flowers are of a rich and lovely soft apple-blossom pink. The plant is of recent introduction, and shows no signs of becoming commoner, though quite easy to grow. Of the small Rhododendrons I think it incomparably the best-unless I am to make an exception in favour of the newly-shown and figured $\boldsymbol{R}$. intricatum, which, if the Botanical Magazine tells truth, has big flowers that verge on blue! As to this, the Jew Ofella can think as he chooses; the colour is by report a very rare attractive shade. Otherwise the little Rhododendrons run dreadfully to unclean lilacs. Myrtifolium, ovatum, parriflorum are all useful plants; so is their cousin, the deciduous Rhodora canadensis, an American peat-bog plant, of rather untidy habit, with dull flowers of bad tone that appear before the leaves. As for Rhododendron kamschaticum, this much-vaunted rarity is not, I think, worthy of a high place. It is a minute, almost arctic shrub, wiry and frail-growing, with very large single blooms, which alas! (at least whenever I have seen it) were of a sad, unmeritorious magenta.

Of Chamaecistus I have already spoken, but one AzaleaRhododendron remains to be described, much more in sorrow than in anger. This is the marvel that I talked of in the Garden of Asia as Azalea 'Gloria,' and before its beauty all other Azaleas flee and hide their heads. And I say this deliberately; as you go up to Nikko and beyond, to Yumoto, all the wild hills, to eight thousand feet and more, are a rolling prairie fire of Azaleas, in every shade of splendour, from the candid amber or salmon of mollis, through the whole gamut of yellows, white and orange, to scarlet, crimson and violet. And 
then suddenly comes Azalea Gloria into sight, and all the others are forgotten. Azalea Gloria is really Rhododendron dilatatum, and it makes a solid band of colour across the hills below Nantai-San in the strangest way, never descending below or rising above a level so sharply defined that its bounding lines never seem to shift. A hill that just rises to the required height is capped by the Rhododendron; a greater one is barred by it straight across the slope.

Rhododendron dilatatum is a tall, loose shrub, with silver-white bark, deciduous, and blooming before the leaves. Only on mature plants are the flowers freely produced. They come before the leaves, and are very large, of the purest and most brilliant cherry-pink, absolutely devoid of the brassy or magenta tones that disfigure so many of the Azaleas. A well-flowered specimen is the most beautiful sight $I$ have ever seen in the way of a flowering shrub-the effect is of an innumerable crowd of rosy butterflies alighted, each by itself, on a naked silver tree-so delicately balanced are the wide trumpets, each on a distinct pedicel of its own. With great difficulty and after many failures and delays did I succeed, two years ago, in importing a hundred young plants of the Rhododendron. Of these only about half a dozen survived, though treated with every care. Rhododendron dilatatum is an Alpine shrub, and the rigidity of its limitation proves that its requirements are definite and imperious. It grows in the loose spongy soil of the mountain woodland, and its roots love to wander through the cool, light mass amid the great stones beneath the surface, which preserve the moisture even more faithfully than the faithful copsewood and humus above. And I have little hope that, except by some rare fluke of some individual's luck, or some individual plant's persistence, we shall ever be able to make an easy garden plant of 
beautiful shy Rhododendron dilatatum. Meanwhile, too, I am haunted by a doubt whether the name or my memory is false. As to my memory, I can absolutely swear-to the glory of that rosy Azalea; but have I, have I, after all my trouble, succeeded in getting the right name? To doubt is weakness; I must steel myself against it. But the fact is that last year one of my few surviving plants emitted one poor sad flower. It was magenta. It was ugly. Yet there is the silver bark, there are all the other details. Beyond question the bloom was only poor because the plant was young and sad and homesick and hectic. With restored health-if ever that arrives-will come also the size, the purity, the radiance of the blossom I adored at Chuzen-ji.

After Rhododendron come Kalmia and Camellia (for I have nothing to say of Stuartia, and Gordonia, and little of rare, beautiful, white St. John's-Wort-flowered Eucryphia pinnatifida). And the Kalmias are all failures here, though once $I$ had hopes, reading that the glorious mountain Laurel occurs in heavy yellow loam as well as in peat on its native mountains. But no; big latifolia and charming little angustifolia dislike me equally; and hardly less, too, the rare, delightful miniature form, angustifolia alpina, which I collected in the Rockies. This is an absolutely prostrate trailer, woody and wiry, narrow-leaved, with brilliantly glowing little cups of crimson. I had great difficulty in getting even incomplete roots, and my plants have never done anything more than survive, and even that is more than I can claim for the majority of them. It loves damp alpine hollows, in peaty places, and, to all possessors of peat, might well prove a treasure.

Of Camellias, I have made but little out of alba plena and Donckelaari, which are generally recommended for outdoor culture. And reticulata, though I had it un- 
protected in the open through two winters, is really an indoor plant - the most gorgeous, perhaps, of all solitaryflowered shrubs; its broad, loosely built blooms being larger, lovelier, richer, and nore graceful, to my taste, than those of even the largest, loveliest, richest Rose. Its intense gentle carmine has a quality of luminosity that I know in no other floral red, to the same degree; it seems to light up a room with its presence, and glows like the steady heart of a fire. Even as the Rose is less stodgy than the horrid, fat Camellias that Marguerite Gauthier affected, even so are the blooms of reticulata less stodgy than the regularity of the typical double Rose. The Camellia's one lack is fragrance; otherwise its glory, its tossing profusion of petal, its revealed core of golden foam, make it the successful rival of any Rose that ever bloomed.

The only scented Camellia is C. Thea-more famous as the tea-plant. This is practically hopeless, I think, for outdoor culture. I have gathered it at Nagasaki, as a semi-established wild plant, drooping its sweet, delicate bells modestly beneath those dark-green leaves to which the world owes so incalculable a debt of health and happiness. But for our gardens Camellia japonica and Camellia Sasankwa stand pre-eminent. Sasankwa is a quite small, frail shrub, throwing up one slender bough to five feet or so. In autumn, these boughs are bent beneath the weight, along their course, of many large flowers, in shape and size and colour exactly those of Rosa canina, but having the artificial, waxy texture of all the Camellias. But Sasankwa is an uncertain plant in England, and has given much disappointment. Of an imported batch all will start by thriving-then, suddenly, ninety-nine will obstinately, inexplicably die, while the hundredth goes on prospering like a bay tree. I give mine any rich soil, peaty or no, and trust 
to luck. I have lost many, and succeeded with a few, and never yet flowered one.

Camellia japonica will probably never reach, in England, the huge, tree-like proportions it attains in Japan. But it is an absolutely certain doer, almost anywhere, perfectly hardy and requiring no sort of care or protection. It is more, of course, of a wild-wood tree than a rock-garden shrub, but when well-developed, has a rare magnificence, with its grey, smooth trunk, and its burden of flame-like crimson flowers, single, golden-eyed, that nestle amid the dark, glossy leafage. It is so one sees it in the wood above the Shiba Temple-Tombs in Tokio, and from the shade one looks down and notes how the fierce sun beyond kindles each one of these fiery blossoms to a ring of scarlet flame. For, in the type-form, the blossoms, much harsher and hotter in colour, have the same luminosity that you get in reticulata. I grow a white form, too, Yuki migüruma, Snow-circle, which is one of the purest and loveliest things I have ever seen. Camellia japonica does not carry the individual flowers for very long, and their tendency to drop when touched has made the plant unlucky in Japanese romance, as it is thus credited with an analogy to decapitation and sudden death.

Of the Daphnes I have already treated of the special rock-garden species-cneornu, rupestris, and alpina. But indica claims notice here, for its absolute, indestructible hardiness. My plants hail from the Tokio Plain, and have never quailed or blenched before the most awful winters, though quite without protection. They grow on, too, like weeds, in any soil, and I only trust they will one day take it into their heads to flower as profusely as they grow. The same rusticity could probably be proved of Dauphini. Another valuable species or group is that diversely named thing, Daphne fioniana, neapolitana, 
collina. Whether these are all names of one or of distinct sorts I dare not dispute. Let me call my plant collina, and so praise it. It grows in any soil, quite robustly, though sometimes a branch dies off for no clear reason. It develops into a round bush of small, leaden, evergreen foliage, three feet high or so, and each straight shoot is capped, in June, by a head of deliciously-scented rosy-pink flowers, like those of indica.

Daphne Genkwa is an outstanding, notable kind, very rare in cultivation. It hails from China and Southern Japan, and labours, consequently, under a reputation for doubtful hardiness. As a matter of fact, 1 imported my plants from the Tokio Plain, with the result that they turn out able to stand anything in the way of weather. A pot-plant, in the open, suffers far more, of course, from frost, than does a plant whose roots are safely buried in the ground, with only one surface to feel the cold. Last winter a number of Japanese Plums, even, in pots, were killed off by frost; not a single pot-plant of Daphne Genkwa took any hurt. This plant, economically important in the manufacture, I fancy, of paper, is a small, very frail, straggling shrub, deciduous, with thin, velvety, greyish leaves. The bark is soft, dark brown. The flowers, born in few-flowered clusters before the leaves, are larger than those of any other Daphne, and of a very clear, beautiful, blue-purple, like those of a fine lilac. Of Daphne striata, a close cousin of cneorum, and reported a lime-lover, my imported plants turned out, after all, to be mere collina; Daphne arbuscula is a very rare little novelty, quite easy to do with, in peat, which seems to me exactly like a minute form of cneorum with the diminutiveness, but without the gorgeous blossom, of rupestris.

With Laureola, Philippi, Sophiae-the dingy, greenish yellowish Daphnes, no rock-garden need concern itself. 
Remains only Daphne Mezereon, our sweet rare native. In almost every cottage-garden in March you will see the bare, leafless twigs of the Mezereon clothed along their length with its big magenta flowers, armed with a fragrance keen, sugared, bitter, curiously ominous of the malevolent poison lurking in the whole plant, and concentrated in the glossy scarlet berries that succeed the bloom. Though rather capricious, the Mezereon, in its typical and its white form, is to be found all over England, naturalised, even, in wood and coppice, while on the upper Alpine meadows it abounds. There is only one spot, in our islands, however, which claims to possess it as undisputed native. Ling Ghyll is a narrow, deep gully, cloven abruptly between the fells at the back of Ingleborough. Its steep sides are clothed from top to dim, wooded, water-haunted bottom, with bushes of the Mezereon, which no external agency can well have introduced to a spot so remote from man, so utterly lonely in the wild heart of the hill country. Another speciality of this strange, magical glen was Saxifraga umbrosa, also claiming this for its only genuine station as a wild plant in Great Britain. Alas, the London Pride has disappeared for many years now; they say that incursions from Giggleswick were fatal to it. But the stubborn wood and fibre of the Daphnes will resist anything short of pick-axe and dynamite. As for me, I confess that I love this Daphne better in Ling Ghyll than in my gardens, where its colour vexes me, and its heady, evil fragrance troubles me with obscure terrors.

And now comes the lesser fry of flowering evergreens. Let me not, though, rashly apply such an epithet to Cistus, noble race, which, however, is not for the most part enthusiastic about my garden. Let others, in hotter, sunnier, sandy climes, run riot with crispifolius, salvifolius, formosus, algarvensis, corbariensis, undulatus, ladaniferus, 
laurifolius. I envy those fortunate ones; even as I write my brain is filled with the hot, poignant fragrance of a Mediterranean cliff, flogged by the full glare of midday, till all the sweet plants, all grey lavenders, all straggling thymes, all odorous, gummy Cistuses pant in thrills of

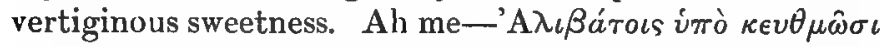

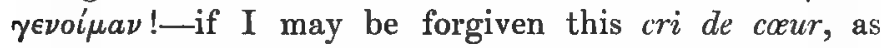
thought of Cistus calls me back to the sun-bruised incense of the shrubs above the Madonetta. ('Du Grec! ô ciel! du Grec! Il sait du Grec, ma saur!')

My only hardy Cistuses, as a matter of fact, are laurifolius, florentinus, undulatus and lusitanicus. And all these are so easy to grow that I need say nothing of their culture. (Of course no one will plant them in shade.) Laurifolius is only less gorgeous in bloom than ladaniferus-big, snowy, profuse in blossom, though the flowers soon fall. The whole plant, too, exhales a delicious scent of violets, which simply haunts the air, and cannot be emphasised by squeezing or breaking. Florentinus is a white-flowered hybrid, attractive, but much less so than either laurifolius or lusitanicus, which latter is, to my taste, the most beautiful of all. It is similar in growth to laurifolius (both are bigger plants than undulatus and florentinus - this last, the child, I rather fancy, of undulatus and laurifolius), but rather frailer and more straggling. The huge, fugacious flowers are snow white, but each of the five petals is marked, at the base, with a round spot of dark maroon.

It is a far cry from Cistus ladaniferes, laurifolius, lusitanicus, several feet in height and bulk, to the minute Rock-roses, with their countless, reckless display of brilliant flowers in every shade, from white to crimson. But these, too, are to be ranked with Cistus; their easiness, hardiness, commonness, make it as unnecessary to recommend them as it is inevitable to grow them, in any 
open place, over any sunny rock. Besides all the innumerable single and double varieties (Amabile is a double ball of crimson scarlet, and there is a similar lemon globe called Ball's Green) of vutgare, notably a copper-coloured one from Mr. Wolley-Dod, and a beautiful big rose-pink variety, I grow also purpureum and roseum, species so far doubtful as far as the flower is concerned. Then comes umbellatum, tall, erect, wiry-leaved, with heads of snowwhite flowers. This is tender and miffy, though less so than the, to me, impossible Tuberaria, so abundant by the roadside over the hills from Cannes. But our own most rare white-flowered native, Helianthemum polifolium, from Brean Down (you see masses of it, too, on the railway cuttings as you leave Dijon), is very valuable, and so is the tiny grey bush of $\boldsymbol{H}$. lunulatum, with its profusion of small lemon blooms. And a special favourite of mine is the too seldom seen $H$. oelandicum, which I collected in the Oberland-a wee, frail thing, with little blossoms of brilliant gold.

As for Helianthemum vulgare--type of all its kin--no culture, in the sun, comes amiss to it, but there is one cultural recommendation I should very strongly make to every one who grows it. Cut it over hard, as soon as the spring blossom is done. This causes the plant to break anew, forming a neat round tuft; and has the further advantage of securing a second season of bloom later on. Not to mention that otherwise the Rock-rose grows leggy, lanky, sickly, and ultimately moribund if left too long to its own devices. The same advice I have already given about Potentilla fruticosa, and it is, of course, of the first importance in the case of all slender, tall-growing shrubs, from Lavandula vera to Boronia megastigma.

The same applies, too, to Ereica and Pernettya. Past Pernettya I slide, for though useful little berried heaths, as it were, in the rock-garden, they have never made any 


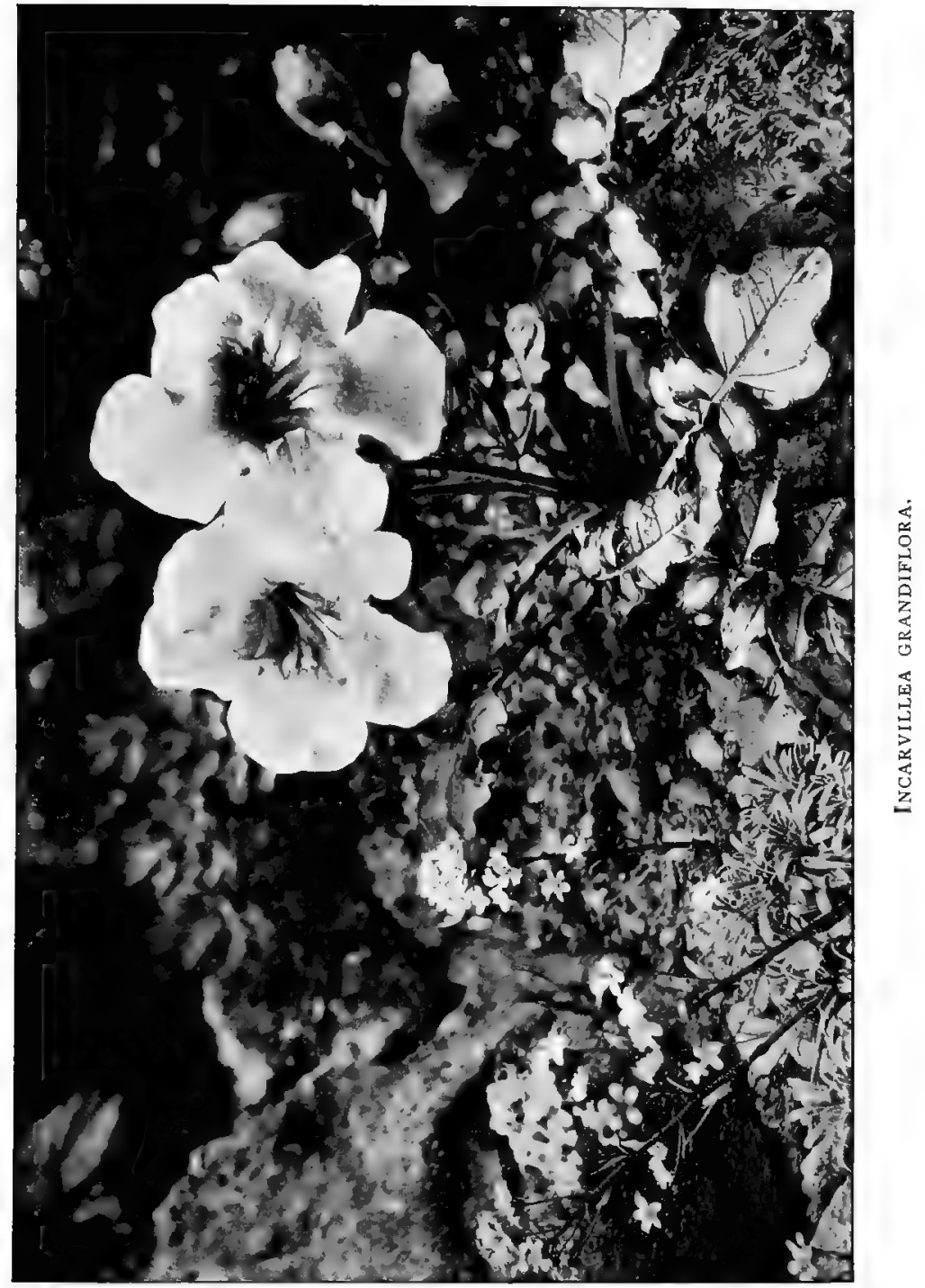


appeal to me. But no garden can be without the finer varieties of Calluna (Hayes, of Grasmere, has a white form so long and elegant in the spike as to suggest a Spiraea japonica), and the various hardy species of Ereica itself-carnea, mackayana (lovely, if impermanent as this fleeting world of false desire)-lusitanica, mediterranea, ciliaris. This last is a rare, beautiful little native from Dorset heaths, with heads of big brilliant bells. Another is vagans, from Cornwall, with fine bushy spikes of white. All these enjoy hot, sandy, peaty soils, and have no marked love for me. Mediterranea, however, thrives brilliantly, and blooms at the most improbable times, while lusitanica has now formed a great tall bush of five feet high or so, which makes a delightful filmy shelter for Epigaea repens. And of my heaths, the most precious is the Irish Bell-Heather-Daboeocia polifoliawhich you will see on either side of the road as you drive across the wild land between Sligo and Galway, through Connemara. This is a very easy-going plant, which luxuriates with me, and even more in peatier corners of England, with ovate leaves and long, loose spikes of very large white or rosy-purple bells, carried on stems about eight inches high, and precious, like Ereica carnea, in the rock-garden, for its habit of blooming from early till late. Under the shelter of Ereica, too, come such things as Arbutus, Vaccinium, Arctostaphylos, these two last species containing one or two useful little things for the peaty rock-garden, which, besides possessing no dizzy degree of charm, are too hostile to my garden to earn a more exhaustive notice here.

'The Gaultherias give us one big, ramping undergrowth in G. shallon, a North American unworthy of a choice place; and another most precious and elect of dwarfs in tiny, rare G. trichophylla, which you must grow in peat, among stones, at the bottom of a little hollow like a 
sugar-bowl, if you want it to remain in health. Gaultheria trichophylla is not so much remarkable for its small inflorescence, its furry-looking branches, as for the resulting fruits, which are ridiculously large, and of the most brilliant blue, having the colour and the bloom you see in those of Vitis vulpina. Indeed the fruits of the Gaultheria are almost as large as those of a grape.

For the rock-garden, Mitraria, Fabiana, Fremontia, Carpentaria are rather luxuries than necessities; so, too, are Choisya ternata, Perozskia, Parrotia, and many another illustrious shrub which it is one's delight to prove hardy. The same, too, must be said of the Olearias, gunniana, stellulata, macrodonta, nitida, and the ubiquitous Haasti. But, at the base of a rock-wall one may well grow Rosemary, and especially its delightful creeping, rock-hugging variety; together with Ozothamnus rosmarinifolius, so like Rosemary in its aromatic leaves, so like Aster ereicoeides in its spikes of creamy blossom. Another plant I eye tenderly is Illicium religiosum, from Japan, an evergreen, with pale glossy green leaves, delightfully fragrant if you squeeze them, and then, nestling far down between the twigs, big pendulous blossoms of a ghostly diaphanous white, vaguely recalling those of Chimonanthus in design, and sweet with the tense, bitter sweetness of orange peel. This appears to be as hardy as it is rare and precious, though $I$ have not sufficient experience yet to say the same of the Pittosporum, so glorious in great bushes of false orange-blossom along the Italian Riviera. The Abelias, chinensis and floribunda, are pretty, graceful rock-garden shrubs, swaying heads of pink trumpets, undeniably delicate, though, and untrustworthy.

Cotoneaster and Euonymus (though the mottled seaside Euonymus is, I think, the plant I most dislike in the world-unless it be the Aspidistra) give us at least two 
priceless rock-work plants, in two new rarities, Euonymus radicans, microscopically minute-like a woody, frailer version of Helxine Soleirolii-trailing over the stones; and Cotoneaster pyrenaica, which creeps rigidly down the rock, a small-leaved, dense-leaved plant, firmly appressed to soil or stone as it goes, after the delightful style of Veronica chathamica, loveliest of cliff-hugging shrubs, quite hardy, too; evergreen, with spikes of delicate soft blue blossoms late in the season. Nor must I forget Cydonia Maulei, the Rock-Garden Pyrus, a dainty, straggling shrub for rock-work, with big flowers, scarlet with the sad scarlet of stale blood, and round fertile quince-fruits. Another wild quince is the Japanese 'Toringo, Pyrus prostrataor Cydonia prostrata - a frank trailer, winding in and out of grass or hedgerow in Japan, with flowers of a healthier, richer crimson than those of Maulei. The little rock-willows, too, trail firmly over the line of the rocks. I have at times imported them accidentally, and now they have made wide masses in many corners of the garden. I believe mine to be alpina and herbacea; they are particularly charming when their fluffy silver caterpillars emerge.

Of the Brooms to be cultivated there are many to be treated of in their due place. Here I will only say that Cytisus purpureus is a fine little shrub for rock-work, with arches of lilac, rosy or white flowers according to the varieties. It grows about two feet high, and spreads with reasonable freedom. Heuffelianus, rumelicus, nyssanus, anxanticus are novelties from seed, to be proved, and not yet showing signs of being thrilling; our own very rare native, pilosus, is an invaluable, densely close trailer, making a cascade of gold over the rocks. The commoner tinctorius (I am herding Cytisus and Genista recklessly under one name), with its double form, is pretty for a rough corner; and sagittalis, prostrate, cpiphyllum-like 
in growth, producing yellow heads at the end of each shoot, is good for any very hot, dry, rubbly bank where nothing else will do. Genista andreana is the gold-andcopper form of the common Broom, and is splendid up at the back, together with Mr. T. Smith's lovely new hybrids in shades of rose and lemon and coral- $\mathrm{T}$. Smith, Firefly, Daisy Hill, and so on.

We come now to the Pines, Firs, Ivies. These hardly bear cataloguing. Hedera minima is a charming, serried wee ivy, quite stiff and stout, and very effective in the rock-garden. As for the Firs-not to wander into such debatable territory as Thuya and Retinospora-Abies excelsa gives us a perfect miniature of itself in clanbrasiliana. Pumila and pygmaea are other minute firs that adorn and dignify an outstanding coign of the rock. Retinospora obtusa, if I may beg the question, is also good; but the two finest things in this group, beyond all cavil, are the mimic Cedrus atlantica which they call Comte de Digon (or should it be Dijon?) and the rare beuvronensis dwarf of the Scotch Fir-a perfect reproduction of the type, but never of more than a foot's height or so,-and indescribably alluring.

Of the Junipers, prostrata and hibernica are beyond price - the one a trailer, the other erect, columnar. Sanderiana is wonderful beyond the ordinary, though, and so is pachyphlaea, a new introduction from Oregon. Sanderiana is a little Japanese, making a round bush about six inches high. All through the summer it is of a glaucous pearly grey, and with winter deepens to a metallic purple. Pachyphlaea promises to be much larger, and already has more or less columnar varieties. Its distinguishing note is the clear and brilliant glaucousness of its foliage, which is more clearly and conspicuously blue than even Abies Parryi or Cedrus atlantica glauca. Nor, apparently, is any miffiness or delicacy to be feared from 
it. While rare varietal forms like Comte de Dijon or Pinus sylvestris beurronensis must have the choicest foremost places on the rocks-not that they are difficult, but because they are rare (all these conifers are easy, thrifty doers anywhere) - there are some true species which are useful higher up. Pinus Cembra, stocky and so slowgrowing as to count as a dwarf, may be employed as a wind-break. Pinus montana is a quite invaluable lowgrowing, straggling, vigorous little tree, the mountainpine of the highest Alpine slopes, in whose bosky twilight lurk Lilium martagon and Aquilegia alpina. Learning a lesson from this, I have planted mine up with Tulipa gesneriana, and when their green dusk is starred with the flames of the tulip the effect is of a rare beauty. Pinus koraiensis is too uncommon as yet, and too little tried, to be spoken of; people who try Cryptomeria japonica are almost as unwise as they who once revelled in Wellingtonia; and I have never succeeded in getting any live. importations of the splendid tortured dwarf varieties that spring in Japan from that most magnificent of magnified, glorified Scotch Firs, Pinus massoniana. I tried to import the umbrella-headed abortion, Tanyosho, only last year, but my failure was so complete that I shall not repeat the experiment. Finally, if any one wants a big column of green darkness for a high point of some large rock-work, and dares not try the Funeral Cypress, let him remember, in the first place, that exquisite, lace-like Cupressus torulosa is absolutely safe and hardy; and, in the second, if he wants a heavier, darker mass, that Juniperus virginiana $S$ chotti is absolutely and at all points the living double of the great Funeral Cypress, possessing for itself the advantage of being as hardy as a. Sycamore and as easy as a Privet.

As for the Bamboos, $I$ have a lurking feeling that it is unfitting to talk of these giant grasses as either ever- 
greens or shrubs. In any case my remarks will take the form of warnings to a great extent. I know no Bamboo that can safely be trusted inside the rock-garden. Once they start they are the most fearful of growers. Pygmaea is pretty and mild-looking, only a foot high or so, but, when established, it eats up space like a motor, seeming to engulf fresh pastures every hour. Ruscifolia (I am not troubling here with the distinctions between Phyllostachys, Arundinaria, and Bambusa) is even prettier -smaller and neater, with dense little boughs feathered with leaves like those of the Butcher's Broom. So far as I know it, this plant, though also a ramper, may be trusted, as it does not increase so voraciously as pygmaea, and can easily be kept in bounds. And it is certainly most dainty, pretty, and attractive, as well in summer as in winter. Bambusa quadrangularis has proved too tender here, but a brilliant success among the smaller kinds has been $B$. Veitchi. This is dwarf, and big leaved, growing a foot or more in height - a miniature, roughly speaking, of palmata. And round the edge of each vivid green leaf there fades a clear rim of pure white, so that a well-grown dense mass of this is a delight to see. But Veitchi will certainly prove a tyrant. It covers all the Japanese Alps in a close jungle, and in England will probably prove extremely valuable as a covert-plant, as its hardiness is undoubted, and I have noticed in Japan that its vigour always increased as it mounted towards the high cold, while it flagged and died as you descended from the hills.

Of the larger Bamboos, palmata is another plant for general or covert use, a terrific grower when once started; with few and very large leaves to a growth. It thinks nothing of shooting three or four yards underground, and coming up, like Arethusa, in the most improbable places. Away with all thought of it from the rock-garden. 
But nigra-tall, exquisitely frail and graceful-is surely one of the loveliest things in the garden, growing into a gradually increasing central mass, whence all the fairylike culms arch outwards, but never sending invading shoots to conquer the territory far and wide. Henonis is another gracious beauty, too, but my Henonis flowered and died. So no more of him. Bambusa Maximowiczii is a compact, medium-sized plant at present, very plumy, but stiff, in which I am inclined to have a certain amount of confidence, though in charm he cannot hope to rival the grassy elfin grace of nigra. Erecta has been my latest surprise. It seemed a neat, mild grower, whose habit was a tuft, and whose height was about three or four feet of stiff culms. What, then, was my amazement when, last season, my Erectas, one and all, made new growths three inches round or more, that went sailing stiffly heavenward to eight or ten feet, with promise of corresponding increase again next season. As this seems a perfectly safe and hardy Bamboo, it will probably prove of very high value in the garden, more especially as it forms a clump and does not run. As for Metake, dear and gracious old friend, first of its race to prove to us how ridiculous it was of us to be timid and nervous about trying Bamboos in our climate-well, Metake itself is a little too vigorous, despite its wonderful beauty, to be admitted to the rock-garden. And senanensis is too much of a new-comer to be prophesied about yet, although already I think I can proclaim that he is hardy and very graceful.

With regard to the culture of Bamboos, and recording again my warning that for the rock-garden only ruscifolia can be trusted on the rock-work, and only nigra and erecta in bigger places, with only nigra, erecta and Maximorricsii in the bog, I can go on to say that the sole requirement of the hardy Bamboos is a rich, cool, 
deep soil, in which they by no means object to a good deal of moisture if the drainage be good. Add to this a sheltered glen or corner, where spiteful spring winds cannot assault and hurt the young, upshooting growths, and your Bamboos will grow as in Japan. They are, indeed, damp-climate plants, and wild-garden plants, essentially ; impatient of control, and far too glorious to be broken in. Their charm is their high, imperious grace: Group them up some glen in majestic clumps, and you will have your reward. With me they thrive in garden and in wood, but in the heavier rainfall of the Lakes they develop tropically, and make great jungles in the misty, steaming Himâlya climate at the northern end of Windermere. Above all, though, let no one think that by planting Bamboos in a dense, serried mass, and making little wobbling walks between them with blocks of white stone, you can produce anything in any way fit to be called a Japanese Garden. In the real Japanese garden the Bamboo hardly figures at all, if ever, its whole growth and character being so alien to the scheme required. And in no part of England, remember, will there be any difficulty or danger about cultivating the hardy Bamboos. They are as robust as brambles, and their only fault is their excessive vigour. Of course there are innumerable greenhouse kinds in China and the Tropics. Of these, naturally, I make no mention. Let us hope it is one of these that is the agent of a certain peculiarly appalling Chinese torture. 


\section{CHA P TER I I I}

\section{Ranunculaceae, Hapaberaceae, Trucíferae}

I AM tired, I declare, of waiting for my herbaceous Clematises to bloom. I had integrifolia and Fremonti from seed, under promise of splendours to come; yet though I have nursed them for years I have never seen a bloom. Erecta, though, and the larger heracleaefolia are fine, handsome herbaceous plants, leafy and large, with abundance of flower-clusters, like masses of wee blue Hyacinths. As for the large climbing species of this notable race, they have no place in the rock-garden, unless you have a vast space to cover, and trees for them to make a jungle of. This is just where both my gardens fall short, so that I have never, except in the ordinary garden, been able to use beautiful things like Clematis grata, Henryi, tangutica, Viticella, Jackmanni, and lanuginosa, all of which should make a foaming background of white and gold and violet to the huge blockbuilt rockery that slopes up to a brow of coppice or wood. However, if I lack Clematis, I have Atragene; and Atragene is to all practical purposes indistinguishable from Clematis. My plants of the American Atragene verticillata are yet but young; the European Alpina, however, gives me more and more delight every year. It is a slight trailer, and I have found it, in seed, meandering among the bushes in the Maritime Alps, just below the level of the Primulas. In early summer it produces 
blue or lilac flowers, large, cross-shaped, but very like a Clematis. This dear little creeper has a splendid Albino form; and both thrive easily on any sunny rockery (I daresay they would thrive in shade quite as well) in any cool, sound loam.

On the heels of Clematis must come Anemonopsis-in flower so like Atragene, yet so different in every other way. Anemonopsis macrophylla is a singularly beautiful Japanese herbaceous perennial, throwing up great, handsome leaves, recalling those of a Cimicifuga, though the whole plant is juicier and less tough. The flowers are carried on tall, graceful stems, and are vaguely reminiscent at once of Anemone and of Clematis-large, pale-purple and white. Anemonopsis has a bad reputation, I gather, in gardens, and I have suffered many things at his hands ever since I saw him years ago, blooming gloriously at Edge, and resolved that happen what might, I must and would possess him in health. Many failures, however, at last disgusted me, and when a final stock came to hand I said I couldn't be bothered to make any more beds or fussments for such an ungrateful creature. He must go out with other herbaceous stuff, to shift for himself in a rich border of peaty loam fattened with manure. I confess I thought that Anemonopsis would be much annoyed, and sulk even worse than he had been in the habit of sulking when care had been bestowed on him. With the amazing contradictiousness of plants, however, that Anemonopsis has simply taken possession of his strip, and throws up tall sturdy shoots after the wildest winters. $\mathrm{He}$ is a deep-rooter, and evidently will take kindly to deep, nourishing soil. And, this granted, he seems to ask for neither protection nor care of any kind. (Latest news: this tale is much too rosy.)

As for the Christmas Roses, I don't think I need tell my experience of them. They are splendid people- 
always thrilling, even if they are not beautiful-and all they want is rich soil and to be left alone. Nothing beats the snowy niger - such a preposterous paradox of a name! But the bluish torquatus is attractive, indeed, and so are the purple olympicus, the rose-red orientalis, with its many varieties, the bright purple colchicus, the native foctidus, like a fountain of pale-green foam, and, I imagine-for I have never succeeded in getting itthat marvellous plant, the true lividus, from Corsica, which sounds like an enormous foetidus-a column of spouting green spray. Lateus I have never had, and my collection is not at all complete, worse luck; but those I do have give me a great wish to make it so, if ever I got time to specialise on more than twenty specialities at once!

The Adonises are very much praised as a rule. There are three or four yellow Alpine species- wolgensis, pyrenaica, vernalis, amurensis. These are so alike to the casual eye as to need little differentiation. They all have very finely divided leaves, like green clouds, and large yellow flowers. But the yellow is always spoiled, for me, by a certain acridity of tone. It is just tainted with green, and has a bitter, thin, unpleasant shade. I have never been able to like any Adonis, I am sorry to say, except amurensis as one saw it used in the Japanese toy-gardens. These toy-gardens are a landscape in a pan a foot across-some range of hills, or river-bed, or promontory by the sea. Tiny, tiny plum-trees stand on the margin, aglow with blossom, beside some ancient water-worn boulder, and there are generally two or three wee golden buds of Adonis amurensis coming out of the ground like a dumpy little Aconite-just small globes of gold, nothing more. In this stage it is a treasure, but it loses all attraction for me as it grows large and coarse, even as a slum-cat is delightful in the kittenstage, but erelong develops the full unattractiveness 
of maturity. The Adonises are quite easy to cultivate, but I rather hope, by now, that I have lost or parted with all mine.

Paeonia and Delphinium, those very gorgeous persons, are not, of course, suited to the small rock-garden. But hard indeed must be the heart that can exclude them. The species of Delphinium that I have grown are dictyocarpum, scopulorum, and tatsienense. Of these tatsienense is so immeasurably the best, that I shall let the others go without replacing them. Tatsienense grows anywhere in the sun, is about a foot or eighteen inches high, and produces clouds of bright blue flowers on graceful branching stems. I have also wrestled with cardinale and nudicaule, the two scarlet species. The sun-loving, delicate Californian uudicaule has been an utter failure here. Cardinale, also a Californian, seems a better plant, but I cannot really do it justice until I have given a good trial to the stout little seedlings that I now have ready to go ont. ${ }^{1}$ of better-known species, I will only say that the tall Hybrids are glorious for high places on the rock-work, and that the dwarf, Delphinium grandiflorum, has the largest flowers and the most brilliantly splendid blue. The old Belladonna, too, is among the best, small enough for the rock-garden, bearing loose spires of big blossoms, tender in their Cambridge blue as the sky of early morning. This delight thrives anywhere, but very rarely seeds. There is also a white form of grandiflorum and an exquisite gentian-, or pale sky-coloured form, as there is also of its twin, cashmerianum grandiflorum. And all are perfectly easy to grow.

Paeonia roittmaniana is a rarity, a herbaceous species with big sulphur-yellow flowers, which, like all the

1 They throve robustly, and sent up stalwart spikes. And then the slugs came and ate every one of them clean down to the ground. 
Paeonies, only wants rich soil and neglect. Wittmaniana, however, differs from the others in sometimes dying off inexplicably. Whitteyi major is the loveliest herbaceous plant I know, as Moutan is the finest-well, shrub, one must call it. Of course I mean the single Whitleyi; the double is beautiful, but of no account in the rock-garden. The single IVhitleyi has flowers like a huge water-lily of pure white silk, and the heart of it is a tassel of fine gold. No one ever imagined a lovelier thing.

As for the wild red Paeonies, I do not think very many of them are worth troubling about. 'There are so many single hybrids now; I have just established, in their second year, a big batch of single herbaceous Paeonies from Japan, and I expect to see marvels this year. 'The species, lobata, Russi, peregrina, officinalis corallina (who lives on the Steep Holmes Islet in the Severn Sea, among the rocks, but basely suspected by some of being an alien) tend to be leafy in growth, small in flower, and with a tiresome shade of lilac or magenta in their reds. You have to be careful about this always in buying Paeonies. Only buy by sight, if possible. Far different is it with the white species. The Japanese obovata, whose pearl-white goblets I remember above Shoji, is a jewel quite outside any condemnation; as are albiflora and edulis and the precious Emodi; while there is even a certain rare variety of the magenta lobata called 'Sunbeam,' which has flowers of a splendid luminous scarlet.

As for the Yellow Tree-Paeony-Paeonia lutea-well, I am waiting till that drops a little in price. Besides, though thrillingly exciting, I don't gather that lutea compares in beauty with Moutan or albiflora. Its flower seems rather small for the leaf, and recalls to me a bloom of Nuphar advena stuck fraudulently on a Paeony-plant. As for culture, all the species are alike: give them deep soil, a more or less shady place, and let them alone. 
Close cousins to Anemone are the Thalictrums, of which our limestone fells abound with one, minus, in foliage hardly less graceful than the better-known adiantifolium, and gracious, in June, with tall, airy showers of yellowish tiny tassels. You will see it waving from the inaccessible cliffs of Sulber and Gordale; nor does it offer any sort of difficulty to the gardener. Our other interesting native (flavum is rather a coarse, gawky thing) is microscopic Thalictrum alpinum from Upper Teesdale, a wee, delicate, inconspicuous high-alpine which you may cultivate carefully in a select peaty corner. Anemonoeides is a real beauty, with big Anemone-like white flowers, which, I don't know why, has never yet done much with me. It has a good reputation, too; perhaps the fault is mine for having only tried it in the Old Garden. Some day I will attempt it again in the new one. Light soil, well drained, in a sheltered choice corner, is recommended for this. Of the larger sorts I have a great love for petaloideum (and hope great things of polygamum and foliolosum and chelidoniifolium, reported splendid). Petaloideum has beautiful glaucous grey leaves, which unfold at first rather like those of Ranunculus rutaffolius, and then, on stems about a foot high or more, heads of large cream-white flowers, rather like those of the Traveller's Joy on a lessened scale.

'This plant likes any border soil. But the most generally valuable for large-scale gardening is unquestionably Thalictrum aquilegifolium. So splendid is this, and altogether admirable, that I cannot restrain my enthusiasm for it until I come to the greater bog-plants. One finds $T$. aquilegifolium in damp alpine meadows all Switzerland over, and in cultivation it takes very kindly indeed to any cool deep loam, forming, in time, enormous clumps that need no care. The leaves are very large, pale green, magnificent as so many broad spreading plumes of a magnified 
Adiantum farleyense; the flower-stems reach to five feet or more at their best, and carry far on down the season a wide foaming mass of white blossom, which, in one form, is pale purple. No plant is handsomer for the big boggarden, or the cool border. Delavayi is a novelty, and a little uncertain so far. It seems everything that it should be, and in growth is like a dense robust minus, with leaves of a metallic bronzy grey. The abundant flowers are of a very pretty, soft mauve, and large enough to make quite a feature.

Isopyrum thalictroeides is a wee cousin of the Thalictrums, very close to them, and of perfectly easy cultivation in light loose soil, rather poor than rich. The plant is quite small and graceful, with the fine, dainty greyishgreen leaves of its kind, and three or four charming little white flowers carried on short foot-stalks, very early in the season. It is a Swiss plant, but not, I fancy, very common. I have never seen it wild, and believe it to be rare-at all events in Western Switzerland and the Oberland.

This, I think, covers nearly all the Ranunculaceæ that are valuable in the rock-garden. The little false Aconite of early spring is too common, and the big true Aconites too large and too wicked to find any place in the rockgarden. One need not look twice at any Monkshood to see that he is an evil, poisonous person. So away with them all, unless you admit the beautiful white Levantine album, or the new twining volubile.

Sanguinaria canadensis, with its variety called major, is so like a cousin of the Buttercups and Anemones that he must certainly come next. He occupies a certain peaty bed in the Old Garden underneath my big bushes of Magnolia Kobus and Magnolia Watsoni. The Canadian Bloodroot is so called because he bleeds. When you dig up his fleshy tubers they ooze gore in a most unpleasant 
way. And their bleeding is a symptom of annoyance too, for Sanguinaria hates being moved and cut about and worried. Give him a quiet corner under some deciduous tree, and he will increase perpetually and multiply, sending up early in A pril his pretty rounded leaves, veined, and glaucous grey (they are, I do believe, the prettiest of all leaves in nature; like a vine's, but rounder, more regular, and smooth), and then, even before they are unfolded, expanding his large snowy flowers, like nothing so much as a pure white Celandine on a stalk about six or eight inches high.

Of the other Poppyworts I have little experience. 'The Big Celandine is a weed in the upper valley of my Old Garden; and the Jeffersonias, Stylophorums, and Chelidoniums, or whatever you like to call them, have never hitherto appealed to me very strongly, though I weakened towards Stylophorum japonicum when I saw him blooming abundantly with Anemone trifolia in the mountain copses on the way up from Nikko to NantaiSan. But even Stylophorum japonicum is, after all, only a glorified Chelidonium majus, brilliant in flower, but rather plebeian in growth. As for that common Japanese weed, the gigantic plume-Poppy Bocconia cordata-well, it is a weed here, too-and, for all its stately splendour, I regret ever having admitted it, or any of its kind.

But the essential glory of the Poppy family is Meconopsis, a race scattered most of the world over, but concentrating its efforts in the Himâlya. Our own country has one, though, the delightful little Welsh Poppy, which no one can be stern enough to keep out of the rock-garden, although he knows how soon he will deplore his laxity. For the Welsh Poppy is a dreadful weed; but then he is so very fascinating, and when the worst comes to the worst, he is an easy plant to cope with. You can grub him up fairly easily; and, however thick your 
jungle of Meconopsis cambrica, it never gives you the heart-breaking trouble of one single runner of Gout-weed or Pig-nut-may their names for ever be accursed! Meconopsis cambrica has a soft orange-coloured form, too, whose colour is singularly rare and beautiful; and, besides, he stands among the few Alpine plants possessing an indispensable double variety. I detest doubles as a rule, but in candour I must own that the double yellow Welsh Poppy is a fine thing; as for the double firecoloured form, well, there is nothing to beat the ferocious splendour of it anywhere in the garden, loose puffs of flower, shading from clear yellow to the most furious vermilion orange, that is Meconopsis cambrica aurantiaca plena, a plant so splendid as to make it worth every one's while to learn his truly awe-inspiring list of names. And, add to all this, that these varieties of the Welsh Poppy seed-at least here-abundantly, come almost always faithful to their parents, and thrive no whit less hilariously than the common ancestor, except, indeed, that they make stouter bushes, and blossom in far greater profusion, their bloons continuing right through the summer, with a second burst in autumn.

Meconopsis aculeata is the good wine that needs no bush to those that have seen him at Kew. I doubt if anything more beautiful exists anywhere, or can exist. 'The leaves are handsome, cordate, more or less five-lobed, brownish with hairs, and long prickle-like bristles. The flowers are carried in a pyramid, perhaps a foot high, and are large, more or less nodding, and, at the best, of an iridescent blue-violet, glistening like silk. The plant is a North-West Indian, and all these Himâlyan and mountain species are rather bad customers to tackle. It is said that they inhabit the mist-zone of the ranges, and therefore enjoy conditions extraordinarily difficult to reproduce in England. 
Angustifolia, simplicifolia, bella, grandis, racemosa, horridula, integrifolia, punicea, compose a grand total of beauty very hard to beat, and also, I fear, rather hard to enjoy. Very quick drainage, good deep, deep compost,rough, peaty, gritty, sandy, yet rich,- - with an exposure neither bleak nor overshadowed, make up my prescription for these gorgeous exotic Poppies. Thriving in such conditions I have young plants of racemosa (which thrives anyhow, in ordinary soil), aculeata, grandis, simplicifolia, and integrifolia. Of course, I dare not claim success until they have flowered. And then, I greatly fear me, they will probably die. For these plants are generally biennials, or, at least, have a tendency to be monocarpous, that is, to die as soon as they have safely flowered and set seed. Nor is seed, as a rule, very certain to fill and be fruitful; nor, even so, is it particularly easy to raise and rear. The easiest to deal with, probably, is integrifolia, whose enormous lemon-coloured globes have made the sensation of the Temple Show for two years past. Punicea, to my taste, though not to most people's, is even more attractive, with its pendulous, great ragged-looking blooms of a deep, obscure scarlet. It is more possibly perennial than integrifolia, which is frankly monocarpous, but seeds very fairly well.

As for simplicifolia-there, indeed, is all my hope stored. It is said to be the counterpart of integrifolia, but with flowers of a soft, clear blue. Ask what our Expedition thought of it when first they sighted Holy Lhasa and the Golden Mountain of the Potalá, with the clear blue of heaven above, and the clear blue of $\mathrm{Meco}$ nopsis simplicifolia filling all the foreground. My young plants seem strong in growth, and are now in bud, but what frightens me is the uncertain colouring of these blue Poppies. Wallichii, besides its azure glories, produces seedlings of every dull shade of brown and mauve; 
the same liolds good of bella, aculeata, simplicifolia, and probably of all. Horridula and racemosa are supposed forms of one plant, and rumour threatens that their big purple flowers also fluctuate to dowdy lilacs.

Grandis is only a promise, so far; it looks mighty fine and stalwart; Heaven send its beauty be in proportion to its vigour! But sad experience teaches gardeners that vigour, in a new plant, or fertility of germination in seed, spells ugliness-things that are really worshipful are too apt to be slow to springing and faint in growth. And it will be well to mention here that Meconopsis petiolata is declared a synonym of Stylophorum diphyllum by Nicholson, while Meconopsis heterophylla is a tall Californian annual with very pretty orange-tawny flowers, black-spotted at their base, that smell like Lily of the Valley. Meconopsis nepalensis is a biennial or monocarpous species, carrying very tall spikes of nodding pale yellow flowers high above lovely great fluffy rosettes. It is among the less uncommon species, and has never taken my affection captive, probably because it is so like, but so inferior to, its superb cousin Meconopsis Wallichii, the best known of all the exotic species. Meconopsis Wallichii carries spikes similar in foliage, growth, and size to those of nepalensis, but the flowers are, or ought to be, of a pale, bright, silky blue. I say 'ought to be,' for the colour varies dreadfully, and seedlings of one batch will yield, as I have said, besides the celestial tones, most horrid lilacs, brownish purples, faded or dingy shades unworthy of admittance to the garden. At Kew, in the peaty bogpits, Wallich's Poppy makes a gorgeous show, but here, of course, no such wet treatment is necessary; any cool peaty corner, in sun or shade, does equally well. Having flowered, the plant dies, and there is, first of all, the anxiety of ascertaining whether it has set any sound seed; then the trouble of raising it; then the long waiting 
period before you see whether your batch has borne you good, pure colours or no. But no trouble is too great to be taken with a Meconopsis.

And at this point, with however little regard for proper order, I am going to talk of a genuine Poppy, which is in aspect exactly like a Meconopsis. Papaver tauricola is a very handsome Levantine, whose proper place is here, rather than with his closer kin, whose name he shares. He is incredibly like Meconopsis Wallichii in habit, and bears a tall fountain of orange-salmon flowers, no less beautiful than remarkable. I fear he is monocarpous, but he is certainly hardy, for he luas sailed through the winter on a perfectly unprotected piece of the rock-work, and is now making broader rosettes than ever, and freely emitting lateral growths, which encourage a faint, foolish hope that he may be perennial.

Cathcartia rillosa is a humble, but near cousin of Meconopsis, with very silky vine-shaped leaves and large golden flowers. It only grows about a foot high, and has most unexpectedly, I confess, proved its hardiness by surviving the winter as heartily as any native. One gets into the way of expecting Sikkim-Himâlyan things to be capricious and miffy. The other Cathcartia, lyrata, I have never grown, my seed always having proved sterile.

Of the Fumitories, I cannot help loving our native or naturalised weed, Corydalis lutea, with its dainty maidenhair-like leaves, and its persistent, cheerful, yellow flowers. The Yellow Fumitory runs about old walls in England, and is quite delightful somewhere at the base of the rockwork, confined to a nook and well out of the way of doing harm. For, of course, it is an intrusive pest if you give it any room near choice things. Its cream-white variety seems rather rare, and is very attractive indeed. Corydalis solida I grow, but not with enthusiasm, on 
either liand; the prettiest Fumitory I ever saw in my life still dwells among the dead leaves round a Korean monastery high on a hillside, buried in forests (the only forests now left in Korea, for the pious monks have respected what the foolish peasants have everywhere else destroyed). Does any reader know this Corydalis, I wonder? In early March it gleamed here and there amid the fallen leaves - the daintiest little flower, with fairy-like, frail foliage, and a few rather large blossoms of a delicious violet. It has a small bulbous root, but all my efforts to bring it back into cultivation proved vain.

The vast Natural Order of the Cross-bearers evidently thinks that in providing us with all our important vegetables it has done quite enough for humanity. For few other Natural Orders are horticulturally so barren of charm; among the Cruciferae that one can use in the rock-garden-or, for that matter, in any other flowergarden either-there are astonishingly few of any great merit (such as Aubrietia, Aethionema, and Ionopsidion), and but few of any merit at all. The race is, generally speaking, an open-ground one, found most abundantly in the Old IVorld, and such Cross-bearers as we like to use are generally quite easy of culture.

The greatest and most important group is that of the Aubrietias, plants of the very first rank for any sunny, light, and not too choice corner of the garden. I have them all over the place as edgings to the stone-work, where they look lovely in their time-so many cushions or torrents of rose, carmine, or violet. By now the species have been swamped with garden-raised varieties, and these, in turn, occur perpetually in almost every batch of seedlings, so that every one will do well to buy packets of some good Aubrietia-seed and select their strain. Moerheimi is an especial pet of my own, and we have one called Craven Gem, which has the great merit 
of carrying its fine purple spikes long after all the other Aubrietias are over. As for Fire King, Dr. Mules, Pritchard's A1, Purple Robe, and the many other named forms, they are glorious in colour, but not invariably nor everywhere, quite so robust in character as the types, I think; or, perhaps, it is that some of them have a rather lax, straggling habit. Speaking generally, the Aubrietias will bear anything in the way of culture except shade and excessive moisture.

The Arabises, I must frankly confess, I almost detest. To me they seem rank, coarse, evil-smelling, obstreperous creatures. I am now describing Arabis albida and its varieties, but no Arabis, think I, has any great beauty. No form of albida, not even the double one, is really admissible to any small rock-garden; and, even in a large one, there are so many better things to fill rough corners with, that there is no need to waste space on an Arabis. The Alpine tufted species are less tiresome, only because less rampageous. Sturii is an uninvited guest here, and is still welcome. He came in something else, and now has made himself quite at home, a neathabited rosetty thing, with heads of white blossom. Arabis lucida variegata is useful too, with shiny rosettes very neatly variegated with yellow. And I also grow a pretty creature whose name is usually made a battlefield, some people calling it Billiardierii rosea (the name I bought it under) and others aubrietioeides. This last name exactly describes it; it has erect spikes of big pale pink flowers like an Aubrietia, and also the same woolly leaves. It very much dislikes damp, and, on the whole, is miffy. As this is the case, why be bothered about growing what is, to all intents and purposes, a not conspicuously beautiful Aubrietia, with a far worse constitution than any Aubrietia ever raised?

Alyssum gives us the precious, little, honey-scented, 


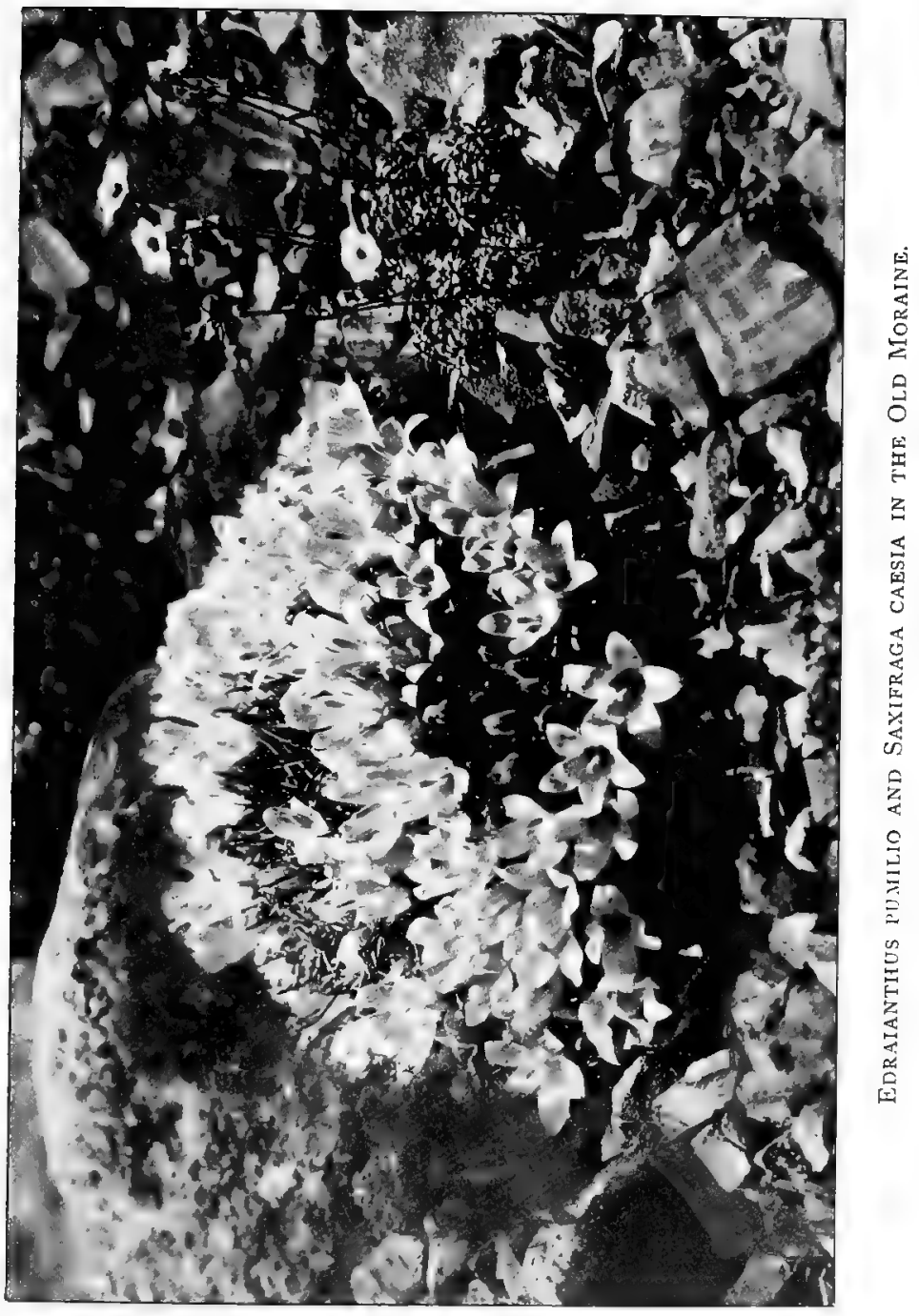


white-flowered native annual $A$. maritimum, now called Koeniga. Then there are montanum and alpestre, plants of the Southern Alps, prostrate and more or less greyleaved, with heads of blossom that have a certain acrid, mean tone in their yellows. They have double varieties which are fairly pretty. Alyssum gemonense is a seedling here, and proves the best of all in colour-a really pure, gentle yellow; Shivereckia podolica, otherwise known as Alyssum podolicum, is rather an uninteresting, whiteflowered plant, and both species seem very fertile and robust. Alyssum saxatile is a well-known plant, and really invaluable with its dense masses of grey foliage, quite hidden by the astonishing abundance of its yellow flowers. The variety citrinum is paler in colour and even more attractive. The double form and the variegated form move no emotion in me. My own favourite in the family is the rather rare and delicate little Alyssum idaeum, the only one of its race I know that can be used, or deserves to be used, in any choice place on the rockwork. Idaeum is a small, prostrate species, with tiny roundish leaves in pairs down its stem. And it is the leaves that make the plant so charming, for they are absolutely silver-not white exactly, not glaucous, but true silver. All the Alyssums, I believe, without exception, are southerners, and all want dry light spots in full sun. Their only constitutional dislike is for excessive moisture. And this may be made a rule for all the Crossbearers that one is ever likely to let into the garden.

The Drabas have some reputation, and are generally advertised in rosy terms. I must be honest and own that I don't really like any of them. They are all neathabited, true rock-plants, and no doubt very useful, but I can never feel any enthusiasm for them. Their flowers are mean and ragged in shape, a dullish white, or sharp, bitter yellow. I grow aeizoeides, scabra, and olympica 
hetericoma. The other species all bear a very strong family resemblance to these, and none of them have any radiant loveliness, though $I$ make one exception in favour of the rare dicranoeides, who has well-built, solid little flowers of a soft, pure yellow. He is thriving in the moraine, of which he is well worthy; and as for the others, their only need is a sunny crevice. The one species that does sound exciting is Draba violacea, a deep purple-flowered plant from the Quito Andes.

There are a few other dwarf Crucifers of moderate merit. Hutchinsia alpina is a common, pretty little thing, which soon, if you are not careful, eats you out of house and home, by seeding itself everywhere. Not to mention that the plant itself runs about and ramps in a deceptively modest way, which conceals its depredations till too late, when you suddenly find a dying sprout of Androsace villosa gasping piteously at you out of a dense impracticable jungle of Hutchinsia. But the invader is such a pleasant-looking, hearty thing that I never have the heart to wage internecine war upon him. I have not admitted him to the New Garden, though.

Cochlearia alpina is a dwarf plant, with glossy, heartshaped leaves in a neat rosette, and white flowers, which occurs rarely in England, at high elevations, and haunts the western face of Ingleborough. It is fairly pretty for the garden, but tends to grow rank, and revert to its type. Parrya Menziesii, from the Rockies, I have only just got. It is a near cousin of Aubrietia, with purple flowers, that promises to be charming. Megacarpaea polyandra is a rare, tall plant, of which I have one stout seedling who is now reappearing for the second season. I don't know what he will be like, except that he is bound to be robustious and big. Heaven send he bear no resemblance to my pet dislikes-the Honesties and single Rockets! 
Iberis is another important race of Crucifers-some of them dwarf, and all, to my mind, spoilt by the tone of their whites, which are either dingy or very hard. Iberis correaefolia and Iberis Snowflake are far and away the best for general purposes, and their flowers are clean and pure, though rather cold in tone. Correaefolia is a huge, obtrusive grower, but Snowflake and pinnatu, another good plant, make dignified, pleasant little bushes about a foot high, flowering with splendid generosity. Iberis jucunda is a synonym of Aethionema coridifolium, which leaves Iberis petraea alone to represent the rock-section of Iberis. Petraea is a very dwarf plant, trailing little dark boughs along the ground, and bearing a profusion of white flowers not as brilliant, alas! as some, though extremely pretty. Nicholson gives it as a form of Iberis tenoreana from South Europe. It is a true highAlpine-minute, neat, and supposed to be rather difficult by some people. I have never had any sort of bother with it here, nor, beyond a corner to itself and decent soil to grow in, have I ever given it any attention or coddling. Of the larger sorts, I think one called Little Gem is the best-even neater than Snowflake-forming robust round balls which, in their time, are literally hidden by the abundance of blossom. Tenoreana, sempervirens, and gibraltarica are none of them trustworthy in my climate.

The Aethionemas are certainly the most brilliant of the Cross-bearers after Aubrietia. They are southerners, coming, for the most part, from the Alps along the Mediterranean, where they drop out of sun-baked ledges in a profusion of rich colour. For, almost alone of their race, they have flowers in varying warm shades of pink; whereas the utmost that the generality of Crucifers can do in the way of effect is pale purple, their attempts at red tones being apt to turn out rather weak lilacs and 
magentas. But the Aethionemas are really bright and lovely in their flowers, while their leaves are, for the most part, of a glaucous blue, which makes a dainty contrast. Their habit is that of wiry, rather untidy little flopping bushes, carrying goodly spikes of bloom along the end of every twig. A strong generic likeness holds them all together, and their requirements are all the same, although there are now many recognised and a few unrecognised species.

I grow Aethionemas under the following names:grandiflorum, coridifolium, thomasianum (a rare annual, quaint, but not very pretty) diastrophis, creticum, armenum, iberideum, and persicum. Grandiflorum is far and away the best of the bigger species, and armenum, I think, of the smaller. As for jucundum, that also I seem to be growing well, and so far, in spite of Nicholson, it looks a different thing from coridifolium (if, indeed, Aethionema jucundum be not yet another synonym for Iberis jucunda, which is declared identical with Aethionema coridifolium!) But, as a matter of fact, there is a great deal of confusion among the Aethionemas, and nurserymen are far too careless about the naming of the stuff they send out.

Against the whole race must be set the disadvantage that their hardiness is not absolutely above suspicion. A cold winter will not do them much harm, but a wet one kills them dead with me, unless they are planted high up on an exposed point, with very quick, perfect drainage. Grandiflorum, I think, is the only species which I can pronounce perfectly faithful and trustworthy. Damp winters have at one time or another forced me to replace all the others; and last winter killed me off armenum, which I loved. It made a little furry-looking grey bush, out of a cranny; and I thought it was safe. But no, the winds blew and the rain came down, and Aethionema armenum departed from such a soaking world. All the 
species, then, want a dry, hot crevice-at least in such a climate as mine-and are supposed to have a love of limestone, though $I$ have never found them exacting as to soil. And if they grow too straggly, or have deadlooking boughs, the whole plant should be snipped hard back, like a Box, and then it will make a neat mass again.

The Wall-flowers have given me a great deal of disappointment. Erysimum pachycarpum I liked, and its deep orange flowers rejoiced me. But then it turned out either miffy or biennial or both, so that I think I no longer possess it. Ochroleucum-whose synonyms are lanceolatum and Cheiranthus - I got seed of, which germinated so freely that now it is the burden of my life. It makes a good border-edging plant, with hard cutting, as it forms neat lumps of a bright darkling green, with thousands of fragrant large lemon-yellow flowers. But it is too rank for the choice rock-garden. Then, fired by a most wonderful coppery-orange illustration, I imported Erysimum comatum from Servia at vast expense. The habit of the plants, very long, narrow leaves in a fine rosette, is lovely, but those flowers that should have been so brilliant, turned out ragged in shape and substance, and of a pale quite uninteresting citron yellow. However, the plant is as robust as such undesirable aliens frequently are. Of the dwarfs Erysimum pumilum and Erysimum petrozskianum, I have a better tale: they are very wee, delicate, and pretty, well worth a little extra trouble in the way of a choice corner. Purpureum, too, is a real gem to do with-quite small, with large flowers of a soft, sad purple, attractive and effective. As for Tchihatchervia isatidea, which Mr. Robinson's (or M. Leichtlin's) flaming tale sent all the world in quest of, I greatly fear he praised it prematurely: it proves a shocking miff and mimp, querulous, monocarpous, and no prettier than Iberidella. 


\section{CHAPTER IV \\ 足 Collecting פDap abobe Aralla}

Ir is always with a sense of approaching the most boundless botanical possibilities that one penetrates into the mountain valleys southward of the Rhone. For there, high in each secluded glen, dwell species that scorn the crowded slopes of the Oberland. In the Saasthal, in the uppermost. screes, lives Campanula excisa; in the Turtmann Thal Linnaea borealis meanders through the mosses of the woodland; in the Val de Bagne Saxifraga diapensioeides huddles passionately into the inexorable sun-baked precipices of the Pierre à Voir. And. with these specialities grow also all the commoner glories of the Alps, so that, for one ambitious to collect in the hills, and unable to go so far afield as the Tyrol, the mountains of North Italy, St. Martin Vesubie, or that gardener's Eden the Col de Lautaret, no more profitable advice can be given than that they should put money in their purse and fare hopeful forth to Saas-Fée, Meiden, or Arolla.

At Arolla, indeed, I had my first experience of these tributary valleys of the Rhone. For the wanderer's guidance I may mention that opposite each notch in the vast mountains overhead that wall in the bed of the Rhone three thousand feet and more beneath, there sits in the flat lands over which the great river flows, a little town, with a station on the railway. Thus, immeasurably far above the tiny hamlet of 'Turtmann hangs the opening 
of the 'l'urtmann 'Thal, and Sion, Sierre, Martigny, each corresponds with the gap that opens up towards the terrific snows above. By false guidance, however, I alighted one steaming afternoon at the wrong station, and had two hours to wait before a train would take me back to Sierre, whence, it appeared, you climb dizzily up the rampart of the mountains until you come into the Val d'Hermance, and so, past Evolena, to Arolla.

Few situations of life can possibly be more overpowering than the valley of the Rhone on a hot afternoon in July. It is so very large, so very flat, so very hot-and, above all, it is so straitly bounded, in front and behind, by so crushing, so annihilating a wall of mountains, which in their turn-oh horror! - are divined, even from the depths, not to be themselves the pinnacles of the world's roof that they appear, but mere subordinate pedestals to the real snow region above, whose awful teeth appear here and there as one raises one's eyes to the distances overhead. The first part of the journey from Sierre, however, is made luxuriously by carriage, and it is wonderful in what serene majesty the mountains open up before one as one goes, no longer made terrific by personal fatigue. For, in a carriage, somehow, one loses that appalling sense of utter personal insignificance, minuteness, nonentity, that always paralyses me when first I set my lonely feet on the austere territory of the hills. In a carriage-and a carriage for which one has to pay-one feels once more in comfortable relations with the world into which one has been born and bred, the world of amenities, humanities, personal importance, where one's mortal personality has its place, and where the gaunt enormous hills are not actors in a fearful superhuman drama, but a mere painted mise en scène, a pleasing background to the human comedy.

In long loops, curling and curling upon each other like the rings of a vast python, the white road mounts 
over pleasant slopes of shelving vineyard, orchard, cornstrip, towards the upper valley. Here and there amid the golden stubble gleams the profound velvety sapphire of Delphinium Ajacis, a rare cornfield weed in England, parent of our multicoloured, lovely annual Larkspurs, and one of the consecrated plants which have their name from sad memories of strength and beauty vanished long ago, for whose disappearance the tears of earth are shed eternally-for Aias, for Adonis, for Hyacinth. Sheer below us, far below, lies the valley of the Rhone-the broad river looking ridiculous and undignified in such a bird's-eye view, with its worm-like wanderings, the mapped spaces of its meadows, its fringe of toy poplars, its punctuation of little toy villages, each with a toy church perking in the midst. Away to the left and passing out of sight, the depths are blocked by the fairy palaces and temples of Sion on its crags; and as one mounts higher, so does the opposite barrier of mountains grow every minute more high and wide and awful, broadening and swelling at each step, as the eye, dazed by their prodigious mass, follows the line of their development till it ceases in the snowy spires away towards the St. Gothard.

And from this height one feels the double influence of the two colour schemes that fill the Alps. Far away below, the valley of the Rhone lies dreaming in gold and golden green, a soft territory of sleep, with the sleepy blue thread of the river running through. Everywhere as one looks down, there is green and the kindred tones of green, while the depths of the air themselves are swimming with a dust of infinitesimal gold in the sunlight. And then above, abruptly, begins the dominance of blue. Long slopes of pale cobalt, soft indigo falls of forest, then the high naked sweep of sapphire, fading into distance after distance of serrated colour, far up against the gentle azure of the sky, across which, in the rosy haze, huge 


\section{A COLLECTING DAY ABOVE AROLLA 71}

curling ranges of cloud go soaring in shades of coral, ochre, amber. Here and there in front of their denser volumes, the pinnacles of the mountains are violet, scarred on this side and that with the rich white of distant snow, while the peaks round the St. Gothard reverse the process and are all of warm, rosy ivory, set with irregular jewelled ridges of amethyst, against the faint pink and purple of the thunderous cloud-masses behind them, a score of miles away. And the whole prospect, beautiful beyond our poor mortal comprehension, is on so vast a scale of grandeur, so inhumanly immense, so contemptuous of such dear human details as roads, towns, railways, that every time one meets it at a turn in the loop one gasps anew with the shock, as under a sudden deluge of icy water.

But at last the shoulder of the hill is turned, and we say farewell to the valley of the Rhone. Now the road continues directly up the Val d'Hermance-for we are here, by kindly fate, still in French-speaking Switzerland.

To describe the vein-system of the Swiss waters one must adopt the most severely scientific terms. In fact the venation of the Swiss rivers is perfectly pinnatifidat least, I trust, $I$ am right, as well as impressive, in so explaining it. In milder words, the arrangement of valleys is as follows : there is, first of all (to put the cart before the horse, for the sake of clearness), a great and first-class river, such as the Reuss, the Aar, the Inn, the Rhone, flowing down a deep and broad valley that it has carved through the mountains. This valley lies quite low as regards sea-level, and is fed by contributory streams that come in at right angles from secondary valleys high up in the hills on either side. In their upper reaches it is the habit of these to flow along a fairly level course, and then to achieve their final descent into the main body by a series of crashing leaps that 
disposes of the two or three thousand feet they may have to descend in about a quarter of a mile. A notable instance is the Reichenbach, which foams imperiously enough down from Rosenlaui, and then takes its leap to join the Aar in the most imposing of Swiss waterfalls. (For its rival, the Handegg, offers no such coup d'ail as the Reichenbach, slinking down in all its volume through the concealment of a cañon, with an unmanly coyness as indecent and grotesque as if Moses were to coquet behind a fan.)

The Rhone and the Aar flow among cultivated lands and cornfields, their tributaries from above through the dense pine woods. But these tributaries, in turn draining the lower mountain-mass, are fed by yet other streamlets pouring down at right angles again from the open fell above-(and thus, roughly speaking, parallel with the big river five thousand feet below). And then again, these very streamlets from the upper barrens have carved glens for themselves between the topmost ridges, and are nourished by little filaments of water, trickling down from right and left from innumerable gullies and screes in the high snows. 'Thus, from ever higher and higher, one stream is perpetually flowing at right angles into another, until you reach the last faint runnels that have been washing the feet of Ranunculus glacialis, or carrying vigour to the opening gaze of Eritrichium nanum. I hope I have sufficiently shown that the water system of the Alps is perfectly pinnatifid?

The drive up the Val d'Hermance is beautiful but without event. There is only the one great thing to see at the end of the valley, far up beyond invisible Evolena. Now on one side goes the road over open lands and past sun-beaten banks aglow with the rare yellow Ononis. Then loom into sight a row of portents-enormous, bighatted monsters aligned across the way. These are the 


\section{A COLLECTING DAY ABOVE AROLLA}

Pyramides d'Euseignes. Water, it seems, has in the interminable course of years eroded all this valley. But certain huge stone blocks have sheltered the light friable tufa on which they rested; with the result that each block stands up, like a gigantic toadstool, on a tapering twenty-foot spire. And here these fantastic mushrooms rise aloft securely on their stems, and bid fair to outlast the valley, and grow taller as its soil is washed away. Only man has ever been successful as their enemy. Some perverted mind once conceived the idea of using the pyramids for targets in gun-practice. Popular indignation, however, stopped the irreverence before much damage had been done.

After Euseignes the road crosses to the other side of the valley, and mounts and mounts. At a dizzy depth below, by the foot of the precipice, the river brawls downwards over its rocky bed. The roadway is a mere wrinkle on the face of the cliff. Overhead, as the air clears, hardens, deepens to the cold calm of sunset, the high snows begin to appear, chill and sombre above the last pines. But neither precipice, nor pyramids, nor yellow Ononis can hold one's attention for long against the dominant presence of the Val d'Hermance. For one has not been bowling for long through the upper valley before one comes into sight of its reigning deity. Snow here, snow there, high overhead, is our right; we expect it. But snow is one thing, ordinary white teeth of mountain are one thing; the Dent Blanche is quite another. Away, away at the uttermost extremity of the valley the mountain-spire leaps into sight, and the unrelenting majesty of it is like the blast of trumpets. As I have already said, all these secondary streams flow from some big mother-peak, and these mountain glens end always in a pre-eminent height of snow. The Val d'Hermance is formed like a $\mathbf{Y}$, and while the right-hand 
branch brings a stream down from Arolla and the Mont Collon, the left arm is called the Val d'Hérens, and descends immediately from the Dent Blanche. And at the junction of the $\mathrm{Y}$ stands Evolena, where the traveller may spend the night.

It was on a blazing morning that I set out from Evolena for Arolla, up the steep valley to the right, upon whose bare slopes of grass a pitiless sun was beating. There is nothing but a track after Evolena, so that one must either walk or jog it on a mule. Where, in the lower valleys, it is a question of tramping endlessly upwards through sweltering forests, I myself prefer the mule as the least unpleasant of unpleasant ways to achieve a necessary piece of drudgery. (This may sound irreverent. Remember that I speak as a gardener. Opulent as the pine-woods are, they give a gardener very little of interest. And no one will deny that they can be stuffy and hot to an infernal degree.) But from Evolena, standing so high as it does, only desultory fringes of woodland are to be feared on our upward way to Arolla. So that with an undaunted heart one can set out to walk the six miles or so that lie between the two.

Very soon one has to say good-bye to the Dent Blanche, which passes out of sight as one diverges from the Val d'Hérens. And it is almost with relief that one escapes from that overpowering presence. All ranges and peaks seem to me to have a personal character of their own. Indeed, this is inevitable. Since all things organic and inorganic, all rocks and mountains and trees must ultimately become Buddha, perfect and unchanging, it follows that, of these enormous pilgrims in the road of salvation, some must be farther advanced on the way than others-that all must, in fact, have personalities of their own. And, far down in the scale as the rocks must be, the Dent Blanche is surely farther down than many of its rivals. 
The Matterhorn, arrogant and terrible, has splendour and generosity; the Wetterhorn is obviously good-tempered; Mont Blanc and Mont Rose are two stout and cosy dowagers, Mrs. White and Mrs. Pink; even the Weisshorn has in its beauty an energetic fury that suits well with a pilgrim on the Way-although that energy be sometimes turned to evil. And Fuji-yama is surely not so much mountain as Bodhisatta. Very near the close of its journey is Fuji-san, and no one could be surprised to discover, some morning, that it had faded out during the darkness, and passed away into the Peace, which is Nirvana. But about the Dent Blanche there is a cold and sluggish malice, unsleeping, unhasting, which owns no kindred with the stolid, fund-holding respectability of Mrs. White, the fierce nobleness of the Weisshorn, or the divine tranquillity of Fuji-san. The Dent Blanche, as far as hills can have a heart, has an evil, unfriendly heart, which is very far indeed from learning that Love Catholic, which is the way of Release. The Dent Blanche, indeed, has beauty for its only merit, and therein lies its salvation. For it is unorthodox folly to say that handsome is as handsome does, and that plain faces can hide lovely souls. If the soul be lovely, the face must have its beauty too, by the law of inevitable consequence, that we call Karma, even though that beauty be rare, exotic, hard to see. And, on the other hand, nothing beautiful can ever be altogether evil, since beauty can only co-exist with inner loveliness, or the possibility of inner loveliness, no matter how remote, how deeply buried in vanity, malice, and frivolity. And therefore, in the enormous course of years, there is as sure an ultimate hope for the beautiful Dent Blanche as for any beautiful man or woman who has ever followed desire through selfishness and treachery. For in the very fact of outward beauty lies the promise of inward good. The seed is there, though many a load of 
soil must be cleared away before the Great Light can penetrate its husk and ripen it to germination.

Over the sun-trodden slopes of grass the mule-track mounts to Arolla. The scant, browned herbage wavers in the heat. Little lizards pant in ecstasy on the burning stones of the low wall that skirts the cobbled ascent. A hot fragrance of life and flowers throbs round one as one goes, and from each burning surface of rock rise on stiff, sticky stalks the rosy star-clusters of Sempervivum arachnoideum. Rosy I call them, and rosy they are in our pale air, but there, in that blaze, they are fire-red, glowing, incandescent. And their mats of round rosettes, too, are silver white with dense tomentum. In England we can rarely hope to see the bloom as brilliant, the little balls as snowy with down. The heat it is that achieves both miracles of beauty, and my climate, to speak for myself alone, has no friendly torridness for the Houseleeks. They live-oh yes, they live-and even thrive in a pallid way, but never do they attain the solid silver, the intense glow, that transfigured them on a sun-baked slope of Switzerland. My wet winters martyrise them, my uncertain summers perplex and bore them. On one rock, indeed, in the Old Garden, I had once tectorum, arachnoideum, and Laggeri thriving excellently. Then my manager and I read Clarke's book on Alpines, put our heads together in a pious and humble spirit, and, as the author warmly enjoined, planted all our Sempervivums anew in a mixture of clay and cow-manure. With the result that they unanimously languished and expired.

All the Sempervivums, in fact-and they are legion; I might consume pages in analysing and noting the minute differences that make up the two hundred species or more that are cultivated-are sun-worshippers of the purest Zoroastrian zeal. Of them all, arachnoideum, with its lovely variety transalpinum, is my favourite. Tectorum, 


\section{A COLLECTING DAY ABOVE AROLLA 77}

our English Houseleek, is good and useful. Not far off are triste, Wulfeni, Reginae-Amaliae. Rubicundum is smaller than these last, rare, and very rich in colour, the whole rosette being deep ruby-claret. But of the larger species the finest, to my taste, is the rather uncommon Gaudini from the Southern Alps. The rosettes of this are big, ball-like, clear green, and furry with innumerable small bristles. It sends out babies on long feelers, and carries a stout head of lemon yellow flowers like Catherinewheels. Gaudini, too, thrives here far better than most of its kindred, and in more ordinary soil. Sempervivum calcaratum, if what I have is true, and not confused with calcareum, is magnificent in size and shape; and Laggeri is a charming wee thing, half the size of little arachnoideum, but otherwise similar, with the same downy white globes. For all these-at least in the rainy North -I advise as little soil as possible, some mere crevice in a rock with a pinch of earth, exposed to every ray of sun, and as little troubled by rains as you can manage. And if you wish to specialise on Sempervivum-and you could have no worthier subject-there are Houseleeks beyond number, as the sands of the sea, all more or less casuistically differentiated from the species I have mentioned, which represent the typical beauties of the race,-dainty and delightful as is every other Sempervivum that has ever been glorified with a name to itself.

The way grows hotter as it mounts, and there is no stick or twig of shelter. The heat seems almost too much for all flowers except the Salamander-hearted Sempervivums, for the only other thing which the slopes above Evolena yielded me was a single, narrow, purple spike of Campanula spicata. But erelong the way leads on into a scattered woodland where Campanula pusilla runs riot over the sun-dappled stony slope between the rare trees. In light and shade it thrives equally, and 
under the lee of every stone its little china blue-bells dance lightly on their almost invisible stems.

It was here, just before the trees began to thicken, that I found the dainty silver-pale variety that I call pusilla pallida. Pallid is a word with evil connotation, and I am sorry I chose so dishonouring an epithet for so exquisite a colour as the silvery French-grey that you get in this form of Campanula pusilla. Then the path passes wholly into dense shade, and skirts a mossy boulder as large as a young church. After that it emerges and moves through endless vicissitudes-up and down, in and out of meadow and woodland, peaceful and pleasant to pursue. Somewhere in these parts is to be found, so $\mathbf{M}$. Correvon tells me, the very rare, tall yellow Valerian Hugueninia tanacetifolia, but alas! I never saw it, though it frequents damp, mossy corners where such rank splendours as Lactuca alpina are to be met with.

The great excitement at this part of the ascent is one's first sight of the Arolla Pine. About all waning, dying species, such as Saxifraga florulenta, Lilium Krameri, Campanula Allioni, there hangs a flavour of almost Stuart romance; but Pinus Cembra is the protagonist of nature's tragedy in the Alps. Only in its young stages could the tree possibly be mistaken for anything else. As it grows older it develops a dense, club-like shape, which enables you easily to distinguish its dark, stout columns from several miles away, amid several thousands of its rival species. Pinus Cembra is probably a very ancient species. It is certainly very slow-growing, and, I believe, not in the front rank for fertility. In any case, it is being crowded out of the world by younger species. In the Valais it lingers, in Tyrol, and in Siberia. You first sight it when half-way up the path from Evolena to Arolla, in the Arolla valley, and after that it goes with you all the way to the glaciers at the foot of the Mont 
Collon, becoming the reigning tree as you get higher. Though in the past it has suffered fearfully from the prodigal destructiveness of the peasants, movements are now on foot to establish plantations of Pinus Cembra in favoured places (at Bel-Alp, I fancy, among others), so that its approaching extinction may perhaps be retarded indefinitely. For the forester and landscape gardener Pinus Cembra has no value; for the rock-garden, on the other hand, its slow growth and its dense habit give it very high merit. As a wind-break it acts admirably, and, for general use, ranks only second to the genuinely, permanently dwarf Pinus montana.

Even at Arolla itself you do not escape entirely from the forests, which still linger above you to the right. But the way becomes more open as you advance, skirting shaggy slopes of long grass and summer flowers. Not here, though, can Campanula barbata be seen in such unexampled splendour as in the meadows above Meiden. There its Campaniles seem taller, its great, fringy bells larger, more numerous, more shaggy, more blue than anywhere else in the Alps. I have already praised this plant; now, deliberately, I must say that my praise was altogether insufficient for its merits. Campanula barbata is one of the most perfectly lovable plants that lives. No other epithet is so apt. Other things are more flamboyant, other things are more startling in their colours, but very few plants in the garden have the gay pleasantness of Campanula barbata, the serene, large-hearted charm. Last sight I had of it, I remember, was abloom with all its usual generosity in the depths of London, on a rock in the Physic-Garden at Chelsea.

But if the way to Arolla is not famous for Campanula barbata, in revenge, the sunniest, driest slopes are ablaze with the coralline loveliness of evil-tempered Dianthus sylvestris, most ungrateful of plants. But, indeed, the 
Pinks are a difficult race; I am reminded, by my memories of Arolla, that certain seedling Pinks, of which I held out great hopes in My Rock-Garden, as due to bloom that year in unheard-of loveliness, turned out, after all, to be dull, fringy dowdies of a most vapid and milky description. These came to me under such high titles as cinnamomeus and pruinosus. Only cinnabarinus failed to bloom, and so, most likely, to disappoint. The postponed disappointment, I already fear, is no less certain than the bloom.

And so, past copse and meadow, the track leads on and on, until at last we come to the Mont Collon Hotel itself, sitting lonely at Arolla (which is only a name) above a marsh full of Saxifraga aeizoeides. And in front of this there is nothing but the gaunt, promising desolation of stone stretching up to the feet of the Mont Collon, whose vast bulk closes in the grim little valley. To the right rises another big humped mountain, the Pigne d'Arolla, carrying a few sparse old specimens of Pinus Cembra on its rust-coloured screes. But the hotel stands on the fringe of the last woodland, and the other slope of the glen is clothed rather with copse and tangle of Pinus montana than with any more notable tree. High and high above all this stretches, against the blue, the saw-line of the mountain-ridge, so fiercely planned as to be hardly patient of any snow. Midway stands up the Aiguille de la Zá, a stark pinnacle like some gigantic saurian's tooth, no less waspish and deadly than its hissing mosquito-cry of a name. Standing there before the hotel, as darkness gently cools the air of the mountains, a gardener alone will understand perhaps how the heart of a gardener bounds to think that he has escaped the fertile, unprofitable land of meadow and forest, that he has come at last to the territory of great open spaces, of that illimitable, gorgeous desolation, which 
is the home of so much brilliant beauty, such enormous peace.

The tutelary deity of the Arolla valley is Androsace imbricata. And for the Androsace you needs must go very high up into open spaces to which the open space below the Mont Collon is a crowded jungle. Looking out across the acres of stone, grim evidence of altitude, that stretch before the hotel, it is hard to realise that only far and far above all this do you come into the real openness, the real freedom of heart and soul and eye. The upward way leads you first of all across the rocky wilderness, where little dwells but Sempervivum montanum, and then across the stream, along whose further bank it continues for some time a mild ascent, beneath the shadow of a precipice. Sempervivum montanum need not detain the searcher. It is a rather undistinguished little Houseleek, with lopsided rosettes of pale green, and heads of sad murrey-coloured Catherine-wheels. So, unheeding the small fry of the mountains, one pursues one's way upwards in the grateful shadow of the cliff. Campanula pusilla is rampant everywhere, the immense violet bells of Campanula Scheuchzeri glitter imperially wherever water distils, on wet rocks Pinguicula lifts its purple Gloxiniablooms above its flattened star of viscid, carnivorous leaves, and everywhere Saxifraga aeizoön shows its stout little creamy spires. Only in the moraine garden shall we ever be able to achieve the full charm of Saxifraga aeizoön. On rock-work, in cleft and border, it has high value and charm indeed, but set it thickly on a slope built only of small limestone chips, and there, alone against that background of broken stone, so lovely in its innumerable lights and shades, its tones of lilac, white and grey, will you get the full effect of the Saxifrage, its tidy masses of blue and silver rosettes, the serried solid blooms in their rounded spikes on abundant, sturdy stems. 
I have already sufficiently lauded the easy temper of this group of Silver Saxifrages, but their pictorial effect is apt to be undervalued, owing, as I myself have too readily admitted, to the dull or greenish tones that sometimes damage the brilliance of the flowers, as seen against the uncompromising background of English rock or English soil. But at last I learned my lesson one day below the Laemmern Glacier on the Gemmi. From a lawn of purple Pansy, snow-white dazzling Ranunculus alpestris, and the amazing blues of Gentiana bavarica and Gentiana Favrati, I came suddenly, unexpectedly, on a high steep shoulder of broken limestone. The whole surface of the ground was covered with white chips, and everywhere, over its expanse, rose crowded colonies of Saxifraga aeizoön, gently waving its sheaves between the gorgeous violet stars of Aster alpinus, while Biscutella laevigata made showers of pale gold at intervals, and the hot orange of Senecio Doronicum blazed here and there against the cool soft silver of its leaves. And to harmonise the whole there were frail, rare grasses, plumy, cloudy, that shivered amid the flowers. And there, in an instant, I learned the full decorative value of Saxifraga aeizoön.

But here, on the way from Arolla to the Plan de Bertol, aeizoön is abundant enough on the stones. Sometimes the blooms are heavily peppered with crimson dots; sometimes they are almost pure in their white; sometimes dull and stodgy. And then, all at once, my companion-why should I conceal that this was M. Correvon himself?-darts forward with a cry. There, on a flat rock, thick-set with its ordinary kindred, shines before our eyes the long-sought yellow variety of Saxifraga aeizoön! Though not brilliant, this yellow-it is quite clear and soft and pure-is very easily distinguishable among the duller tones around.

In my rhapsodies over Eritrichium I have touched on 


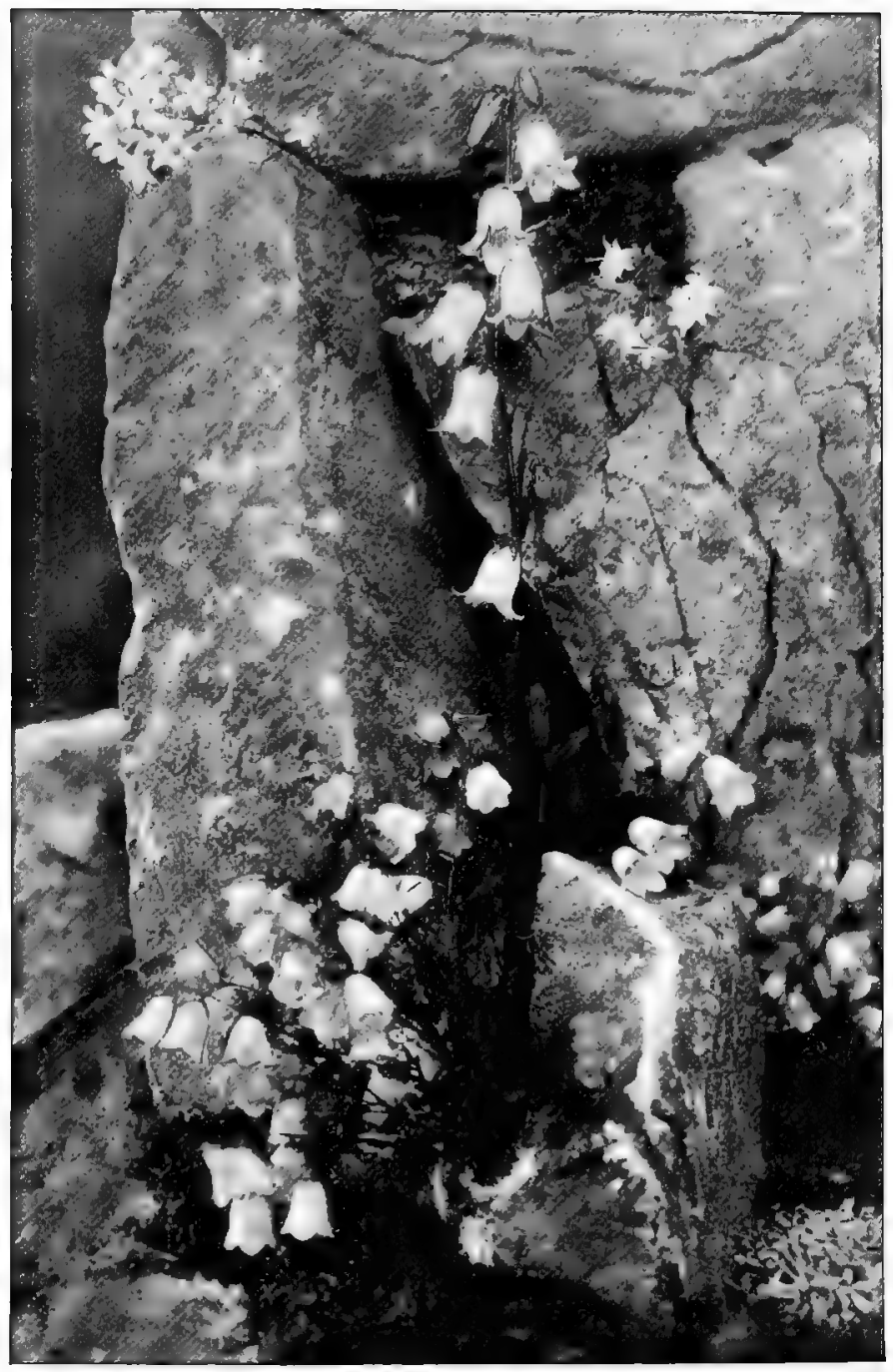

Campanela barbata and Caipanula pusil.la. 

the gardener's joy of discovery. This has a quality which can belong to few other successful quests. For what can equal the delicious moments while one sits down in glory at the side of one's discovery, and finds the moments far too holy and precious to be cut short by the premature introduction of the trowel upon the scene? The thing is there, for us to deal with at our reverent pleasure; meanwhile we must adore every detail of our find, lovingly touch the upturned petals, mark the growth, the health, the beauty, the whole delight of the plant. There is no hurry about precipitating the end. So there, on that flat rock overhanging the precipice, we loiter in worship of the yellow aeizoön; then, when our satisfaction has been fully savoured, the trowel is introduced, cunningly and with piety, so as to remove only a little fraction of the clump-Anathema sempiternal on those who would rend away the whole, and leave the rock widowed of its chief pride! And this, again, is generously divided, that finder and companion may share alike. So we go happy onwards, secure in our knowledge that every rosette and rosettling of these Silver Saxifrages is safe to make a solid little plant by autumn.

Now the track, having passed the precipice, suddenly takes it into its head to mount. And mount it does, with fire and fury, in abrupt, violent zigzags, over a slope as steep as the side of a house, and surfaced with fine herbage, polished and slippery as glass. So quickly goes the climb towards the upper levels that gigantic Mont Collon, now close at hand to our right, seems to sink down beneath us as if through a trap-door. Up and up and up curls the track, still in the shadow of the hillside. The grass is starred with little plants of Silene rupestris, and the dark sapphire globes of Phyteuma pauciflorum. Here and there occurs the one-flowered form of Campanula barbata, which, so far I have never proved constant 
in cultivation. Then, high above, solid rock, reddish, granitic, begins to loom overhead. The track reaches it. Now we are on the territory of Androsace imbricata. Androsace imbricata is within reach-perhaps even within sight. But the keenest search fails to discover any of those expected silvery cushions nestling into crevices of the cliff.

So our upward way continues. Suddenly there is nothing more above us. In another instant we have topped that long dark slope, and emerge, dazzled, into the full glare of day. $U p$ and down before us lie unrolled the lawns of the Plan de Bertol-one golden fire, in the sunlight, of Geum montanum and other little yellow glories of the grass. Looking back across the invisible deep gulf beneath us, we seem on a level with the midmost snow-patches of Mont Collon itself. Our vast, sunflooded tract of colour is closed on the right by a barren wall of mountain. To the left, high above us, stretches a huge amphitheatre of granite cliffs, from whose feet a wilderness of broken stone flows away down towards the grass. A moraine-ice and stone and glacier-mud and water-mounts beyond this from the stream's head to the head of the glen, and on the right, above other stone slopes, a snow-field, daunting, cold, and azure (for the sun has not yet touched it), leads upwards to the Col de Bertol. Now I know that my quest is achieved, for, all round that amphitheatre is a classical station for Androsace imbricata. Meanwhile my companions are more eager to scale the Col de Bertol, whence, from the Hut, the climber is rewarded by a view over the Val d'Hérens to the Dent Blanche. I, for my part, having no love for snowfields in themselves, prefer to spend my day in the more placid delights of the Plan de Bertol. Accordingly the others depart on their way, and I am left alone.

To be alone in wide, great places is sometimes too 
terrible a thing for little mundane man. In the high valleys of the Alps, where the silence is so vast that it seems as if a single uttered word would shatter the roof of the world, the nearness of the Gods is either purifying or appalling, according to one's strength of mood. All the Lords of Life and Death, all Gods and Saints, all Buddhas and Bodhisattas out of the infinite past and the infinite future, they are all there, making part of that immeasurable beauty, chanting in the choir of that eternal silence, incarnate in the radiance of that unstained mountain sunlight. They are the irresistible Powers of the air; the lucid diamond air is тнем. So that, if one be strong enough, from hours of solitude in upmost Alps, one can drink big draughts of immortality, can leave behind for a wholesome hour the unrealities of earthly life, and lose consciousness of the phantom daily self in reunion with the divine eternal Self.

However, if such a mood be not upon you, be careful how you venture into the mountains. Be careful how you go there accompanied by unworthy thoughts, petty ambitions, hopes and fears. For the pure Spirits of the hills are not patient of such affronts, and they will have none of such thoughts in their presence, nor of you that bring them. You will be unhappy in such august neighbourhood-feel ill-attuned, unwanted, disliked. In such a mood, or when weakness and the love of human comradeship is upon one, let us stay happily at the Schweizerhof, or parade the streets of Zermatt. For the terror of the hills is dreadful, cold, annihilating. It strips man of his dignity, denies his existence, reduces him to an ineffectual ghost, a mere $\dot{a} \mu a v \rho o ̀ \nu$ ei $\delta \omega \lambda o \nu$ of his decent Bond Street entity. On level lawns in the Alps I have felt a spiritual terror so glacial and overpowering

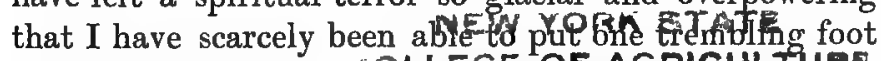

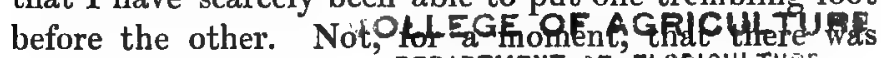
DEPARTMENT OF FLOFIOILLTIVIE

AND

ORKAKENTAL MCATIRULT" T? 
anything tangible or obvious to fear for one's bodily safety in the way of cliffs, glaciers, crevasses, but simply that my spirit, on those days, was too little to cope with the universal Godhead of the world, too fast-riveted in egoism to sink itself in the divine personality. On the other hand, there are days when one is more worthy of that divine companionship, capable of losing one's self and becoming God. And, on such a day, loneliness among the hills is strengthening and sacred.

Nor does the beauty of the place go for much in one's feelings. I don't know that the Plan de Bertol is particularly beautiful, beyond the intoxicating loveliness of clean, empty air, of uncontrolled light and space. Yet there I felt solitude most blessed, whereas high up on the Col that leads over Meiden to St. Luc, in surroundings far more dazzling, and with the dizzying magnificence of the Weisshorn ruling all the mountain world, I yet was glad of companionship; felt the whole thing a magnificent painted scene, stood far outside it, without desire for solitude or closer communion.

Over the grassy knolls of the Plan de Bertol one wanders on, trampling the golden glow of Geum montanum as one goes. The close lawn becomes a carpet of coloursPansies, Primulas, Gentians make its tissue. Then comes the streamlet, dancing down among the glacial buttercups from the stony moraine above. On this, in the sodden blue clay between the blocks, one comes on plants of Saxifragn biflora, drenched and draggled with mud. And here, too, though we are in full granitic formation, I came on one plant of Campanula cenisia. As for Ranunculus glacialis, it is everywhere, now, in wet places among the shingles. Its large, solid flowers shine white as snow, and in the course of years each unit has developed into a solid clump of a hundred plants or so, each separate crown, almost, carrying one of those gleam- 


\section{A COLLECTING DAY ABOVE AROLLA 87}

ing brilliant blossoms, waxy-pure against the gold of their stamens, except where the fertilised flowers are fading to a dim, sad pink. And then, joyous find, comes an isolated mass of Geum reptans. Geum montanum, the golden Mountain-Avens, is a common little glory enough, quite dwarf and vigorous, with bright yellow flowers as large as a florin. And this, in cultivation, is as thrifty and easy a thing as you could have for any sunny rock-work or raised border-healthy, spreading, floriferous-though in cultivation its stems shoot up to six inches or so. But its big cousin, Geum reptans, is very different in every respect. You are generally very high on the last moraines of all before, far ahead of you, on the unbroken grey of the stones, you see a sudden flare of gold. As almost all flowers except the smallest and dullest are now left behind, you cannot imagine what the yellow vision may be. It is Geum reptans, making one compact colony at that point, and notoccurring again over the whole moraine. It is much bigger in growth than montanum, the pinnate leaves standing erect, and the whole plant reaching eight or ten inches in height. The flowers are, I think, the most magnificent in all the high-Alpine flora, from the point of view of combined brilliancy and size. They conquer even Aster alpinus and Senecio Doronicumgreat golden St. John's Worts they are, as large as a crown-piece-yes, and much larger, too. From the stock each parent-plant sends out a thin pink runner like that of a strawberry, which produces a young growth. Thus the species multiplies, yet stays perpetually in the same spot.

In cultivation, unfortunately, Geum reptans is uncertain. It lives perfectly well, even multiplies, with some success. But it very rarely flowers. I am convinced, though, that it will prove (I haven't yet tried it so, but mean to this season) a first-rate moraine plant, since what it 
obviously requires is to be kept awake by sheer starvation, in the thinnest, rubbliest scruff of stone and grit, instead of being allowed to sink into sybaritic sleep in rich garden soil.

Crossing the moraine at last, one sets oneself to climb towards the sun-steeped granite cliff on which one hopes to find the Androsace. As a matter of fact, there is no such delirium of excitement about this present quest as there was about that of Eritrichium nanum. For there all was uncertainty - the place, the moment, everything. Now, on the contrary, I know for absolute fact, that in those baking cliffs overhead I shall soon be seeing Androsace imbricata. And sure enough as I clamber up the last steepest slope to the foot of the precipice, I see the treasure before me immediately - three or four powder-white balls of down, wadded immovably into a crevice. Immovably indeed. Nothing can I do to stir them. Gently as you urge them, they resist indomitably. Pull them, and they break at the neck. It is true that in a covered frame of moist sand, shaded, with plenty of air, you can strike cuttings of many difficult things, such as Eritrichium and Androsace, as easily as Violas; but the pious collector's instant ambition is always to get perfect roots. So I quest along the face of that amphitheatre, beneath a daunting heat beyond words to express, and nowhere do I discover a single amenable plant of the silver Androsace. From every chink its little cushions leer out at me in derision; but in the face of abundance, it seems I must ironically starve. Finally, having perlustrated the whole semicircle, I retreat baffled, and drop down to the moraine again, to eat my four Marie biscuits to the accompaniment of glacier water. Fortified by this repast, however, I decide after lunch to make another effort to secure my lovely prey. I mark a certain little jagged tooth of granite far overhead, standing aloof from the main 
amphitheatre, or rather its last desultory outcrop. There, if anywhere, the rock looks rotten and friable. I set myself a-climbing. Steep is the rocky slope, in all conscience, under the sun. But it is nothing to the space beyond. For here, the tension of the hill's angle relaxing for a couple of hundred yards or so, enormous boulders are heaped and piled in the loosest and most distracting confusion. They are the size of little houses, these blocks, and one's only progress is to climb laboriously up one, then drop into dismal depths on its further side, and so up the face of another. And so on, and so on, and so on, until one feels like an ant in a sugar-basin. At last, however, I reach my little jag of rock, and there have the joy of finding my hopes justified. For the cliff is quite loose and disintegrated here, slab lifting off slab in the easiest and most delightful way. And between these two separable slices, Androsace imbricata in abundance makes the jam of this 'satisfying sandwich' (alas that there is no one present to finish the tag ' and broach the exhilarating marsala ' in honour of the occasion!). Delightedly, then, I lay bare the whole ramification of its silky roots, and take a fair proportion of plants, blameless in my certainty that I am doing them no wrong, but giving them as fair a chance of thriving as any collector's skill could offer. And so, at last, as the sun's majesty goes westering and the air glows with a ruddier gold, my companions are seen far-off, black specks on the snowfields, and when they rejoin me on the Plan, we all continue our rejoicing homeward way together, almost too deeply sated with success to feel more than a passing thrill when, not half a mile from the hotel, as we return along the path, Aquilegia alpina is seen nodding two of its glorious blossoms at us from a bush.

The ascent on the right from the Arolla Hotel takes one on to a different geological formation, which pro- 
duces astonishing differences in the flora. Androsace Chamaejasme is replaced by $A$. obtusifolia. Aster alpinus is abundant in the higher reaches, with Ranunculus pyrenaeus and Androsace carnea; and of larger things the big gentians are very abundant, every possible hybrid of purpurea occurring in every conceivable shade of colour, from dull tawny to claret.

Androsace carnea is a pretty treasure, whose merit has been obscured by the greater merit of his major eximia, and his minor Laggeri. The type carnea is a thin and wiry-leaved species, quite dwarf, with a head of rather pale little Primula-flowers. Eximia has much broader, solider, glossier leaves, with bigger flowers, more abundant, and of a much deeper pink. The type, however, is very well worth growing, and, with eximia, has the strong recommendation of being perfectly easy to grow, quite trustworthy and robust, preferring a light, rich peaty soil, and needing no glass protection in winter, as do the downy-leaved species from the higher Alps and the Himâlya. In point of fact, the cultivator can always tell the easier Androsaces by the fact that their leaves are thin, leathery, and devoid of down.

Another in this blessed category is $A$. vitaliana-sometimes called Aretia vitaliana-pardonably, too, as it is so unlike the other Androsaces. It makes a prostrate mat of dark green, furry branches, and then emits a quantity of brilliant golden-yellow flowers, in shape and almost in size recalling those of Jasminum primulinum. This plant, though perfectly easy and safe in any soil and any decent aspect, must yet be bought with caution. There is a thinleaved, sparse-blooming, small-flowered form of $A$. vitaliana; and there is also a stalwart form, with leaves slightly broader, more robust-looking, hemmed with a ciliation of white down, which produces a splendid abundance of big flowers, whose colour is of the richest, softest, imperial 
yellow. Do not overfeed $A$. vitaliana with too rich soil, and you will never have any complaint to make of him.

There are some other noteworthy species, too, in the carnea group. Brigantiaca makes larger rosettes, but is otherwise very similar, with bigger heads of rather pallid pink flowers; hedraeantha is much more brilliant, yet broader-leaved, with flowers of a fine rose. This is a novelty, hailing from the Balkans, and both species are quite decently easy in any fair cultivation. I have hedraeantha in the moraine, where it throve splendidly for a time, and will probably do so again as soon as it has recovered from the oppressive attentions of a mouse.

All these rosy Androsaces, of course, would be even more beautiful than they are-this is horrid ingratitude, but also truth-if they did not have that faint, faint lilac-magenta tone which so frequently interferes with the purity of colour in the Primulas and their near relations-of whom, of course, Androsaces are about the nearest. Laggeri is, by many lengths, the best of its kin, a tiny version of carnea, so minute in growth that its spreading tufts might be taken for those of some small Hypnum. However, it soon enlightens you as to its charms by sending up a dozen little stems or more, each crowned with a head of golden-eyed rosy flowers, the most brilliant of all their kind-if you except the impossible glacialis. A. Laggeri loves a warm, loose bank of gritty peat-at least, it does here in a moist climate, and is a lovely treasure beyond price-especially as, being a wiry-haired species, it needs no apparatus to ward off winter-rain.

Androsace lactea is a link between the others, and the annual and biennial species. It is, as a matter of fact, very pretty; and yet, so very misrepresentative of the name it bears that $I$ can never love it quite as much as it deserves. It has big rosettes of smoothish dark green 
leaves, and sends up the most admirably floriferous stems of bloom, carrying large, pure white flowers, in graceful great loose umbels. It is a sound-hearted, thrifty, good-natured plant, thriving almost anywhere, even in more or less shade-a condition, I find, generally fatal for Androsaces. (They say $A$. Laggeri will also do in shade; well, it may; but $I$ have always found that every single one of the genus prefers sun.) It is truly perennial, too, and goes on blooming all the summer in a very delightful, pleasant way. I am doing all I can for the poor dear, after so frankly owning that I cannot pay it the debt which I admit I owe. I respect it deeply; love no one can command, and Androsace lactea is too like the dreadful little annuals and biennials for me ever to feel quite fond of it. As for them, they too have neatness and floriferousness. But, with one or two dazzling exceptions, such as Linaria alpina, and Gentiana nivalis-if any one could ever get it to grow-I regard all annual plants in the rock-garden as out of place. They are frauds there, come in on false pretences. Your true alpine is a sturdy soul, who battles with the vast elemental forces of life for half a score of years; - not a little, frivolous ephemera that grows up in a month, and flowers and seeds and dies all in a summer. So away, briefly, with Androsace filiformis, coronopifolia, Chaixii, raddeana, septentrionalis, and their synonyms. They are all pretty, mind you-some of them very pretty indeed; but I personally happen to have that prejudice against annuals or confessed biennials-my dazzling exceptions being only species that are too cogently beautiful to be left out-Linaria alpina, Ionopsidium acaule, Saxifraga Cymbalaria-(I don't say this is cogently beautiful, or that I want it; but it came, and where Saxifraga Cymbalaria comes, it comes to stay). 'Iherefore I'll commend these annual Androsaces generously, but I won't grow them. 


\section{A COLLECTING DAY ABOVE AROLLA 93}

Some of them don't even bear commending, either. A few years ago I got seed of an Androsace called macrantha. I bought it because the name sounded so alluring. A big-flowered Androsace, bless me, what a joy! Who would have suspected a trap? But up came the seed, so thick that I at once smelled out a disappointment; it is only weeds that germinate so eagerly. The seedlings grew like Jonah's gourd, and then appeared the spikes that were to bear the eponymous big Howers. Well, that plant bore the smallest flowers I have ever seen, and in the most enormous calyces. Beware, then, of Androsace macrantha, all ye that have Greek! And as for that rarest of Italian new-comers, Androsace Mathildae, I have not yet tried it, feeling a presentiment that it belongs to the not too easily distinguishable cousinhood of $A$. reulfeniana and $A$. ciliata.

As for propagating; the high Alpines may, with great care, be raised from cuttings struck in moist silver sand, duly shaded. All the sarmentosa group may be pulled to pieces at pleasure, and every piece will grow; - a little more care, please, with villosa and arachnoidea. Most of the others can be divided with ease, and lactea, with the annuals, of course, comes profusely from seed. Raising the rest from seed is hopeless unless the seed be fresh, and, even so, is doubtful, slow work, though ultimately, perhaps, a gain. 


\section{CHAPTER V}

\section{Letween gianthug and Expílobium}

Or the smaller Pinks frigidus and Lereschei are said to be lovely. But then it is a catalogue that says so. However, I hope they may be. So far, they are doing fairly well in the moraine. Microlepis I got with great excitement, from Servia, but it appears to be a minute and not extremely fascinating variety near glacialis, which attempted to prove kinship with that peevish plant by expiring as soon as it could. Dianthus Sternbergi appears to be promising, but I am a little tepid about it, since I discovered that it stands between monspessulanus and superbus. Now all my warmest affection is reserved for the dwarf, cushiony Pinks. Dianthus integer seems to be very uncertain. Many false forms are certainly doing duty for it. I believe I have at last got the genuine plant from Ljubotren, and it looks cosy and distinct in growth, so that I look forward to its flower. Dianthus dentosus from South Russia I have never succeeded in getting. Mr. Robinson's description fired me. A CushionPink with violet-lilac flowers might be so extremely pretty (it might, on the other hand, be horribly ugly); however, as I seem unable to obtain the plant, such speculations are profitless. Dianthus squarrosus and Dianthus subacaulis are two small people I once had, but they have, I think, vanished, without leaving any aching void in my heart. Where, exactly, Dianthus petraeus comes, I can- 


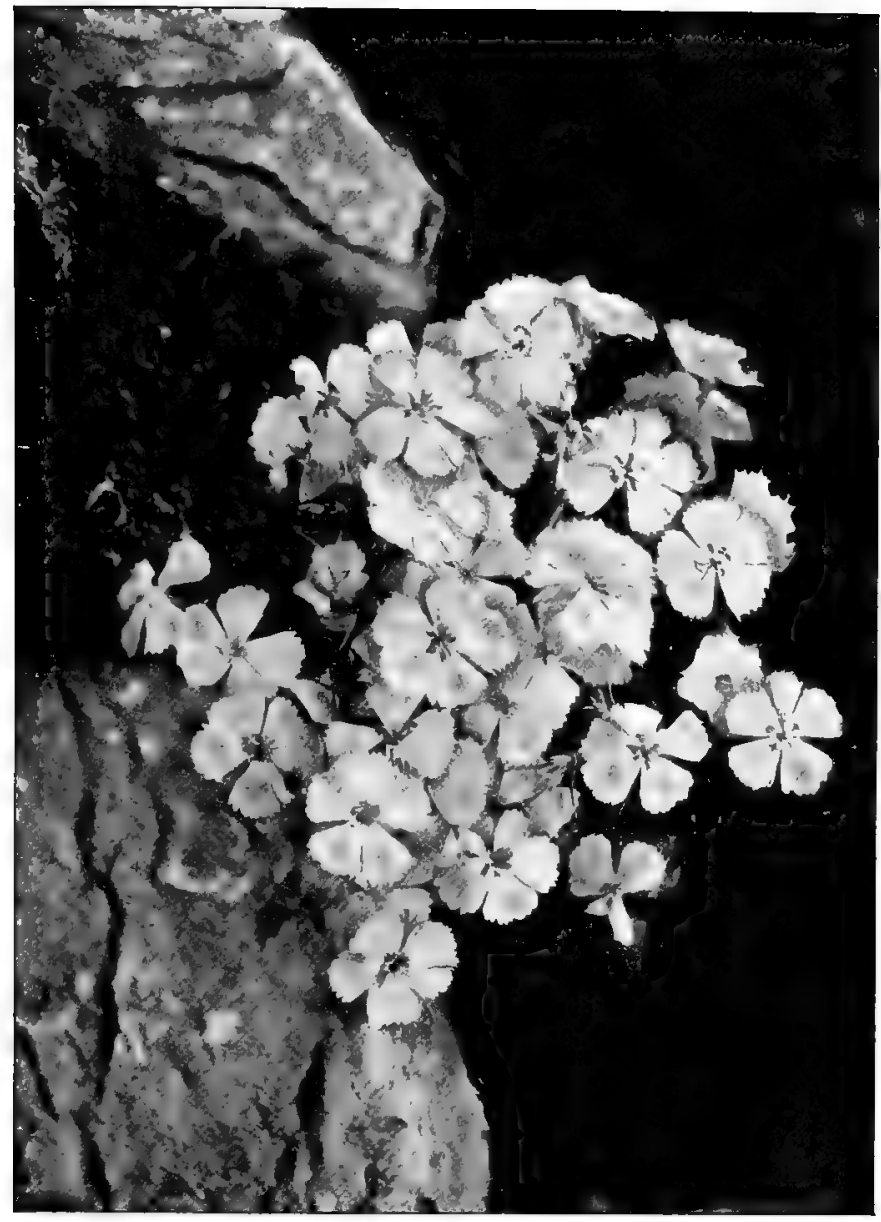

Dianthus neglectus. 



\section{BETWEEN DIANTHUS AND EPILOBIUM 95}

not tell. It has varying descriptions, one of which is suspiciously like that of glacialis. My plant, however, is a thrifty, tight-growing Alpine, with white, fringed flowers, of easy culture and pleasant habit.

Of vaginatus, the true fiery Holtzeri, of Requieni, Seguieri and many others, I only have seedlings at present, so that my utterances would only be those of hope, not those of experience, and what they might thus gain in radiance they would lose in authority. I have also had, my catalogue tells me, a hybrid of alpinus and callizonus. I cannot even remember it; evidently the plant shared the constitution of its father. Dianthus roseus, that was once sent me, is quite falsely named, but is a pretty, small plant, with glaucous tufts and white flowers : and Spencer Bickham is a bright caesius hybrid.

Among my other obscure or doubtful pinks stands a very interesting one that I collected at St. Martin Vesubie, and which, in my own mind, for lack of authoritative name, I think of as serotinus. For the merit of this plant is that it sends up its long wiry straggling boughs in October, and opens its great fringy flowers in November. These are of a brilliant carminemagenta, and glow like sparks amid the deadness of the garden. For the plant, easy and robust under cultivation, faithfully retains its late-blooming habit, despite all temptations of changed season and climate. Very lovely too is another vigorous novelty, no less easy and even more striking. This is a hybrid of caesius and superbus, which makes a tiny bush, clothed all the summer through with innumerable jagged flowers of a rich warm rose. This has the merits of its parents, and is invaluable, - the best, after alpinus and neglectus.

Lychnis has but one exception to the rule of ugliness that taints its colours. In almost all Lychnises (and pink Silenes too) there is a tang of magenta which very 
much unfits them for certain tastes. Lagascae, though, is a precious little plant from the Pyrenees, with bright, pure pink flowers with a white eye, a true rock-plant, rather inclined to be petulant and miffy in temper, demanding a well-drained fissure, from which, if happy, it sprouts like a bush, bearing abundance of blossom till quite late in the season. Pyrenaica is near it, but white, or pale pink. This I have grown, but lost some years ago, and have never replaced.

Lychnis alpina and Lychnis lapponica are so close to each other as not to be easily distinguishable from a gardener's point of view-both small tufty plants with tight, short-stemmed heads of magenta crimson or lilac flowers, varying to white. Alpina is a rare native, found on Hobcartin Fell in Cumberland, and both species are Northerners of the easiest cultivation, but not, to me, of any great charm, owing to the impurity of their colour. Lychnis Viscaria, with its double and splendens varieties, resembles a magnified alpina in every way, and labours (with the new Sartorii) under exactly the same disabilities and advantages. As for the double white form of our common native vespertina, it is rare, easy, and decidedly pretty in its way. Of the Saponarias, ocymoeides splendidissima is indeed a splendid, good-natured trailer, to fall over a sunny rock in a dazzling sheet of rosy blossom. The rarer species, Saponaria reiemanniana, is a novelty which I am trying, which is reported to make free-flowering tufts of pink. Caespitosa is a good thing, making larger tufts of paler blossom. Lutea is a curious and very attractive Saponaria-low-growing, with shortstemmed heads of pale saffron flowers. She dwells in the Piedmontese Alps and blooms in July or August, very delightfully, with blackish stamens to enhance her flowers. Her constitution is not, I believe, absolutely trustworthy, but I have never had much difficulty with 
any of these Saponarias, growing them all on sunny banks.

Of the Gypsophilas, no sane person would admit paniculata or any of the big rampant species to the rockgarden. But repens (or prostrata) is a valuable highalpine, of the very easiest cultivation, forming immense thick mats of pale pink or white blossom borne in showers just above the succulent-looking greyish foliage. Even this species must be kept away from the choicest pets, but Sundermanni and cerastioeides are both neat little tufted things, with quantities of charming, pinkmarked flowers, who may be grown anywhere, even among the smallest treasures. Sundermanni is white, cerastioeides pink with deeper markings. The larger species are sometimes frightful;-I once had scorzoneraefolia as a present, and vastly plumed myself on such a novelty, until it bloomed, and revealed itself one of the coarsest and least attractive of weeds.

The Alpine Cerastiums (Chickweeds) are not, somehow, of very easy culture. They have a way of fading from my garden and my memory too. The rare woolly native, Cerastium alpinum, is fairly easy, if it does not damp off in winter, and its big white flowers are pretty. Glaciale is very beautiful indeed, with round snowy blooms that lie about over the moraine. I have collected him times without number, with every care, but he has never lasted long in cultivation. The most generally useful is the white-leaved tomentosum, so abundantly used in grave adornment; but this is far too rampageous for the rockgarden. And so, really, is Cerastium repens, which I once accepted gratefully, and have waged vain war against ever since. It is a passionately-spreading weed with glossy leaves, and myriads of ragged white flowers, not nearly so fine as those of tomentosum.

Besides verna and gothica the Arenarias give us one 
or two very valuable species. Arenaria montana, for a sunny rock-face, is a splendid hanging plant, forming a perfect curtain covered all over with its shilling-large, snow-white flowers. Ciliata and norvegica are small forms, one decumbent, the other tending to be erect, very near gothica, and not quite so pretty. Huteri is a high-Alpine with big white blossoms, that seems to be thriving in the moraine-garden. Purpurascens is a very charming, free-flowering person of easy culture-a prostrate mass with glossy leaves, and pale lilac stars. There is another plant, a weird, ugly thing, sent me once as norvegica, with grassy leaves, and bunchy heads of rather dingy-white blooms; this is probably Arenaria graminifolia. As for Arenaria balearica, that delightful little Corsican is a perfect weed here, in this moist climate, sowing itself all over the place; and the only attention it requires is the negative one of weeding it up when necessary. For let no one be so deceived by the apparent frailness of those brittle little stems, as to use it as a carpet for choice plants. Arenaria balearica forms a dense, strangling mat, in which, before long, everything else, however vigorous, gives up the ghost and expires. But oh! it is a joy when the whole emerald sheet of it is covered with its wee brilliant white stars. Even here it doesn't like being sunburnt; so that elsewhere it may prefer shady treatment; but in this climate, as I say, the plant is a very weed of weeds.

Speaking horticulturally, nothing separates Alsine from Arenaria-and the Alsines laricifolia, pinifolia, and Rosani are all valuable, thrifty, easy-going plants for sunny rock-work, making mats of emerald fur, and then sending up big snowy blossoms on frail stems. Ledebouriana I have only just got; but there is a very strong family likeness among these plants, and I find a preference very hard to arrive at. 
Not very far from Arenaria is Moehringia, a very curious species from shady alpine woods. There are several Moehringias, but only with minute differences. They all make a filmy cloud of fine foliage, starred with small whity-green flowers. All must have shade and moisture, and are interesting if not very thrilling.

Tunica Saxifraga is a most pleasant treasure from the south, who proves quite hardy and vigorous in this climate, even in open beds-though, of course he is safer on the rock-work, where his neck is safe from excessive damp in winter. I have found him all along the eastern and western Riviera, growing, for instance, among grass and rocks near the lighthouse above Antibes, in face of that most glorious view in Europe-which, over the sea, and over the little, unchanged Greek city, and over all the intervening ranges, has the whole splendour of the Maritime Alps unrolled from end to end, from crown to base, from the Argentera to the last peaks beyond the Col de Tenda. In cultivation Tunica makes a wide cloud of airy green, richly galaxied with innumerable rosy-pink stars all through the season and far on into autumn. Sometimes he is even a little inclined to overflower himself and die-but how different, morally, is this excessive generosity, from the greed of vulgar display that dictates the same conduct in the semidouble Mule-Pinks! And Tunica, too, sets abundant seed, so there is neither reason nor excuse why any one should ever be without him. All he wants is full exposure and good root-room. Then he will be a perennial joy.

And now a sudden burst of candour compels me to burst back upon my own track and make mention of the Milkworts. On the principle that if you have nothing pleasant to say you should hold your tongue, I had allowed myself to pass the Milkworts over in a tactful 
silence. But no; this will not do. I must be honest, and confess before the world that Polygala Chamaebuxus does not seem to requite my affection. I swear I love her wholeheartedly, the little creeping Box that one finds on the lower Alp, with butterfly-shaped flowers of cream and yellow and white and orange (so curiously recalling the colours of a poached egg, à la Portugaise). Rhodoptera is a crimson-winged form, and Vayredae a delightful near relation; but the whole family has no love for me. And this is the more humiliating because these Milkworts are usually the easiest of plants to grow, thriving where they are happy, like so much Couch-grass. But, if the truth must out, it takes a great deal of trouble in this garden to make any of the peat-zone Alpines really comfortable; so that, after much sorrow and expense, I have almost accepted my refusal at the hands of Polygala Chamaebuxus, and betaken myself to other kindlier loves.

Of the Flaxes, any one and every one grows the noble big yellow ones, Linum flavum and Linum arboreum, neither of which is perfectly, safely hardy, though, even here, they are seldom if ever really injured by the winter. But the rock-garden possesses two most delightful dwarf Flaxes in Linum alpinum and Linum salsoloeides. Linum alpinum is like a dwarf almost trailing version of the ordinary Flax, with lovely soft blue flowers. It thrives in any open position, and the wonder is that people do not make more use of it. The other rock-garden species is even less common; Linum salsoloeides haunts the Maritime Alps -I have collected him above St. Martin Vesubie on hot sunny banks below the Alpine region. He is almost prostrate-in a very rare form, of which I only have one plant, he is quite so-making a few wiry branches, furry with narrow green leaves, like a miniature pine-twig. The flowers are large, ice-cold 


\section{BETWEEN DIANTHUS AND EPILOBIUM 101}

white, with darker veining and a purple eye-delicate as Nierembergia frutescens and entrancing as Geranium lancastriense.

The one thing that Linum salsoloeides needs is exposure; the one thing he cannot and will not put up with is excessive damp. Give him a high, hot crevice, and I dare warrant you will have no more trouble with him, but increasing pleasure from year to year. $\mathrm{He}$ is not a difficult plant, but dislikes any neglect of his own pet fads: 'Don't try no impogician with him, for he will not abear it.'

Other Flaxes that come in very handy are the tall, bushy, blue-flowered Linum sibiricum, with its white form - often sent out in plants or seeds for the rarer alpinum, so be careful-a perennial version of the commercial Flax; and Linum viscosum, another south-European, growing about a foot high, with large, soft, pink flowers. These are quite comfortable to deal with, though viscosum must be planted where moisture in winter cannot annoy him. He is a compatriot of salsoloeides, which is hard on him, I feel. For salsoloeides has so pure an elegance of charm, that the stout leafy boughs of viscosum and its big mauve flowers seem, in comparison, blowzy and commonplace.

The St. John's Worts are a large and showy race; and the more ordinary sorts are so well known and so much grown that I need not mention them, except to suppose that no rock-gardener will have the unhappy notion of bringing Hypericum calycinum anywhere near the rock-garden. A worse weed, and a handsomer, was never known. The taller species, moserianum, patulum, nepalense, aureum, Ascyron, Androsaemum, are all valuable for backgrounds, but of plants for the rock-work itself the order gives us a few really valuable ones. Hypericum olympicum is sometimes very beautiful. It is a frail- 
looking thing-at least in the form $I$ knew and loved years since-with thin, wiry leaves and stems, crowned by three or four immense golden blooms. But olympicum, I found, required starvation; in good soil he grew lumpish, and the flowers tried to come out all at once, and made a jumble of it, and looked stodgy and vulgar. And then the plant died; and those I have now don't look to me quite the same thing-their leaves seem rounder, somehow, and thicker. However, I shall not be able to decide until they bloom. Hypericum cuneatum is a small, new Alpine which I have only just got; and Hypericum diffusum, another rarer treasure, was given me some years since, in cutting form, but failed to do any good.

The two bracketed glories of the race are Hypericum reptans and Hypericum Coris. Reptans is a Himâlyan, absolutely prostrate, falling over rock-faces in a dense cascade of little ovate leaves. The flowers appear from July to the end of October here, and are as large as a fiveshilling bit-rose-red externally, and inside, of the loveliest radiant soft yellow, so pure and luminous that they make you look round on a dull day to see where the sunlight is falling from that so kindles them. The plant is unimaginably good-tempered, too, and resents neither wind nor weather; only plant it high on the rock-work that it may stream down in a curtain at eye-level, and show the fresh radiance of its pale golden suns. In spring its mats look dead and drear as Ulalume, but before very long they break up from the base, and soon the whole blessed process of development is in full swing. The plant can be raised with equal ease from seed or cuttings, and on every account-being absolutely without fault, either of appearance or demeanour-ranks high in the first halfdozen Alpines of one's choice. There is also a Hypericum repens, a pretty creature-but reptans so knocks all 


\section{BETWEEN DIANTHUS AND EPILOBIUM 103}

competitors out of the field that no other St. John's Wort has a chance of admiration, except Hypericum Coris.

Coris and reptans set up claims together on the Merry and Cherry Pecksniff scheme: "No connection with the establishment over the way, and if the quality of goods there don't please you, you are respectfully requested to favour me with a call.' And hence it is that these two manage not to enter into any rivalry. Reptans lies on the ground, adhaeret pavimento ; Coris makes a little aspiring bush about six inches to a foot in height. Reptans has green, ovate leaves; Coris has wiry, blue-grey ones: reptans has one big flower to a shoot; Coris has half a dozen smaller, more golden ones, arranged in loose airy clouds. There the dissimilarity ends, for Coris is as happy-tempered and as companionable as reptans in every way, though I hardly think he seeds to the same extent. I collected him years ago in the valleys leading up to St. Martin Vesubie, where you will find him sprouting out of almost every shady rock along the roadside, among the broad mats of Saxifraga lingulata. So far as I know, he propagates best from cuttings, and is only unfortunate in having the unsurpassable reptans for a brother. For the first half-dozen Alpines must not include two Hypericums, or where should we put Gentian, Primula, Saxifrage, Viola? And Hypericum reptans, whatever happens, can never be ousted from his place-not even to make room for the only less perfect Coris.

Of the Mallows not one, I think, has any value for the rock-garden. At least $I$ rack my memory in vain to find one; for the only lovely Alpine member of the family is the gorgeous little scarlet trailing Malvastrum coccineum, which loves heat and drought to such an extent that it makes no pretence at being hardy here. It won't even go so far as to flower even once. Ah, I have got hold of another-Callirhoë involucrata. The Callirhoes 
are so close to Malva as to be almost synonymous. Only involucrata is usually grown, and my experience with involucrata has not tempted me to try any other. For one thing, the plant is another sun- and heat-loving North American, extremely petulant about any undue moisture : for another, its colour aroused in me a pained dislike ; for I could never have imagined so burning and acrid a magenta. (The same objection applies to Calandrinia umbellata and the Calandrinias generally; miffy plants in any damp climate, and of a gorgeously horrible colour-all the worse for being so gorgeous.) Therefore I lost Callirhoë and Calandrinia with feelings akin to pleasure.

Of the Geraniums there are two exquisite Alpines, besides lancastriense. Geranium argenteum is a Pyrenean, who grows about six or eight inches high in a neat tuft. His claw-like leaves are all grey and silver; his big blossoms of a soft delicate pink, with deeper veining. He blooms perpetually, and is quite happy if you give him a well-drained chink, and leave him alone. He dislikes being moved; and he also dislikes any excess of damp anywhere near him. But he is altogether as easy as he is beautiful, and his worst fault is that he is a very bad seed-bearer, and this is all the bitterer because he is even more impossible to multiply by division. Geranium cinereum is very near him in every way, but a trifle larger, a trifle less dainty, a trifle less brilliant, and a trifle more generally robust. Cinereum is, as it were, Nature's rough model for argenteum, which for loveliness, charm, and adaptability to any fair culture, takes very high rank among the alpines of my special favour.

Among the larger Geraniums the most appalling confusion reigns. So I go delicately, as Pilgrim on the narrow way, or Mrs. Gamp on her 'parapidge.' There is, first of all, a very robust, rampageous, dwarfish person 
with big, bright rose-pink flowers, who is very useful for a rough place, and whom I think of as Geranium armenum. Then there is an immense, glorious one with a short blooming period, during which it carries great heads of large, deep violet flowers. The leaves are downy and the growth like a tidy, large Pratense. This, to me, is Geranium ibericum, of which $G$. gymnocaulon is a frailer form. About Geranium Endressi $I$ am in a stew. Have I mixed him up with armenum? Which is it I possess? Oh, I wish they'd flower quickly and make certain! Anyhow 'Endressi' is neat and rose-red. As for wallichianum, I am almost beginning to hold Mrs. Prig's heresy. I have bought him again and again; and now I doubt whether any one really possesses him. I have been sent bushy, blue Wallichianums, I have been sent floppy, magenta-pink Wallichianums, I have been sent so many different and mutually irreconcilable Wallichianums that my poor brain staggers as to the problem of deciding which is genuine, if any. All that I know is that Nicholson's wallichianum looks as pretty as his horrid bad drawing will allow, and that I have never possessed it. (Yes, I've now got it.)

Our native $G$. pratense must not be admitted to the rock-garden. It grows obese; its development becomes rank, its flowers small and dull; and it seeds itself remorselessly everywhere. So it enjoys my misguided hospitality no longer. Its double form, and its various white, Silver Queen, and other fancy varieties, are interesting and rather pretty for an out-of-the-way place. Grandiflorum is a very superb plant, which is to all intents and purposes a pratense with the growth no bigger than usual, but the flower multiplied by two-a notable easy-going border plant, whose name and history are not quite clear. Phaeum, the rare native Dusky Cranesbill, with little blackish purple flowers, is all right for a remote place 
where nothing else is wanted, but does not deserve any choicer entertainment. The white Herb-Robert is a charming little Albino, but a perfect brute for seeding itself all over the garden; and Geranium Lowi seems to me nothing but an enormously-magnified, coarsened form of the common Herb-Robert; while Richardsoni, that I had from the Rockies on high recommendation, is only a weed, like a smaller, neater pratense, with nothing but dull, whitish flowers, poorer than striata's.

Only botanical differences, really, separate the Stork's Bills from the Crane's Bills. The Erodiums are a race of heat-loving Southerners, which seem admirably amenable to well-drained cultivation. They have no very commanding brilliancy, but an extraordinary personal charm which puts them very high indeed among rock-plants for a sunny corner. Their leaves are ferny, finely-divided, sometimes aromatic, sometimes silvery; their flowers, few at a time on long-stalked heads, are generally in very delicate colours, and sometimes most exquisitely painted and feathered. The only absolute dwarf I know is the charming Erodium Reichardi, whose proper name is said to be chamaedryoeides. As life, however, is short, I shall continue to economise it by speaking of Erodium Reichardi. He makes the neatest, roundest flat tufts of stalked wee heart-shaped leaves, and then sends up, each on a two-inch stem, innumerable pure white flowers, continuing all summer through. He comes from Majorca, and I regret to say some of my plants seem to have died in the open last winter, though the larger, Levantine Stork's Bills are coming up as gaily as ever. These are all exquisite, and all enjoy the same, welldrained, dryish treatment, though even here they seem as vigorous as Dog's Mercury. Chrysanthum has pale sulphur flowers; guttatum, white and blotched; macradenium, pink and pelargonium-like, with patches and 
featherings of deep purple that give it the daintiest, slyest expression. Cheilanthifolium is lovely, with leaves like a fern, and dark pencillings on its pure white petals. Sibthorbianum is silver grey, and rose-colour; supracanum, Queen of Queens, has hoary whitened leaves, and flowers of clear pink. All these are so delightful that there is no rivalry. One must have them, every one of them, without exception. The only Erodium to be careful about is Manescavi, a stalwart, great coarse thing which will grow anywhere, with large handsome flowers of an even more truculent magenta-crimson than those of Geranium sanguineum. Personally I like the others so very, very much, in their self-conscious, sweet refinement, elfin and ethereal as Mélisande, that $I$ am all the more set against the rank gaudiness of this herbaceous weed.

The Wood-sorrels, in a race of awful little pretty pests, have the privilege of giving us one of the very best of all alpine plants-a species so serenely beautiful and so easy to grow, that it counts certainly among the first six plants to be mentioned for the rock-garden. (Alas for the others! I have come on three candidates in as many pages.) Oxalis enneaphylla hails from the Falkland Isles, and makes himself tight little scaled bulbs like a miniature Lilium Auratum, which sit safe and quiet underground all the winter. With spring appear the glaucous grey leaves, each like a crinkled cluster of leaflets, on stems about four inches high; then, nestling among them, goodly white convolvulus-flowers, of a delicious brilliant colour, softened to a pearly richness by the very faintest suggestion of flesh-pink. I don't know any more wholly worshipful Alpine than Oxalis enneaphylla, and (whether or no our cool climate has anything to say to it), its hardy thriftiness is quite equal to its beauty. I stuff it away anyhow in loam on some shady ledge, and leave it quite unattended. Even in the fiercest or the 
wettest winters it will take no harm; and then about mid-March its leaf-buds are sure to come poking faithfully up, and soon the flowers are budding. So lovely is this Oxalis, that it could never in any circumstances become a weed. However, it does not try to do so, but only increases slowly and modestly, forming larger and larger tufts, but never pervading the place like its less well-bred kindred, who seem to have no instinct as to where they are unwelcome. I believe the only thing that Oxalis enneaphylla dislikes is excessive sunshine; put it under the shadow of a rock, and it will be pleased with any well-drained soil. The other Wood-sorrels can only be admitted with caution. The pink form of the ordinary Oxalis Acetosella is rare and dainty; Oxalis lobata is small and pretty, with golden flowers; and the profuse Oxalis rosea, with its tall stems and heads of rose-pink flowers opening in sunshine, has surprised me by proving apparently hardy here in the worst of winters. I think these make up the most desirable species; at all events, with these four I rest content.

The vast natural order of the Butterflies, whose Patron Saint is the Sweet Pea, have many treasures for the rockgarden, though there is a good deal of confusion among them, and a certain difficulty of culture now and then. Of the larger - growing things the Brooms are most precious perhaps. Cytisus and Genista come very near together, and both run to yellows, with one exception. Cytisus purpureus is a fine dwarf shrub about a foot or more in height, which spreads freely about, and would be even prettier if its flowers were of a purer, cleaner colour. However, the white form is irreproachable, and there is a variety incarnatus, and another roseus, in which the magenta tone is minimised. Cytisus Ardoini is the gem of the race, a rare and fascinating wee golden-flowered shrub from the Maritime Alps, for a dry sunny bank; 


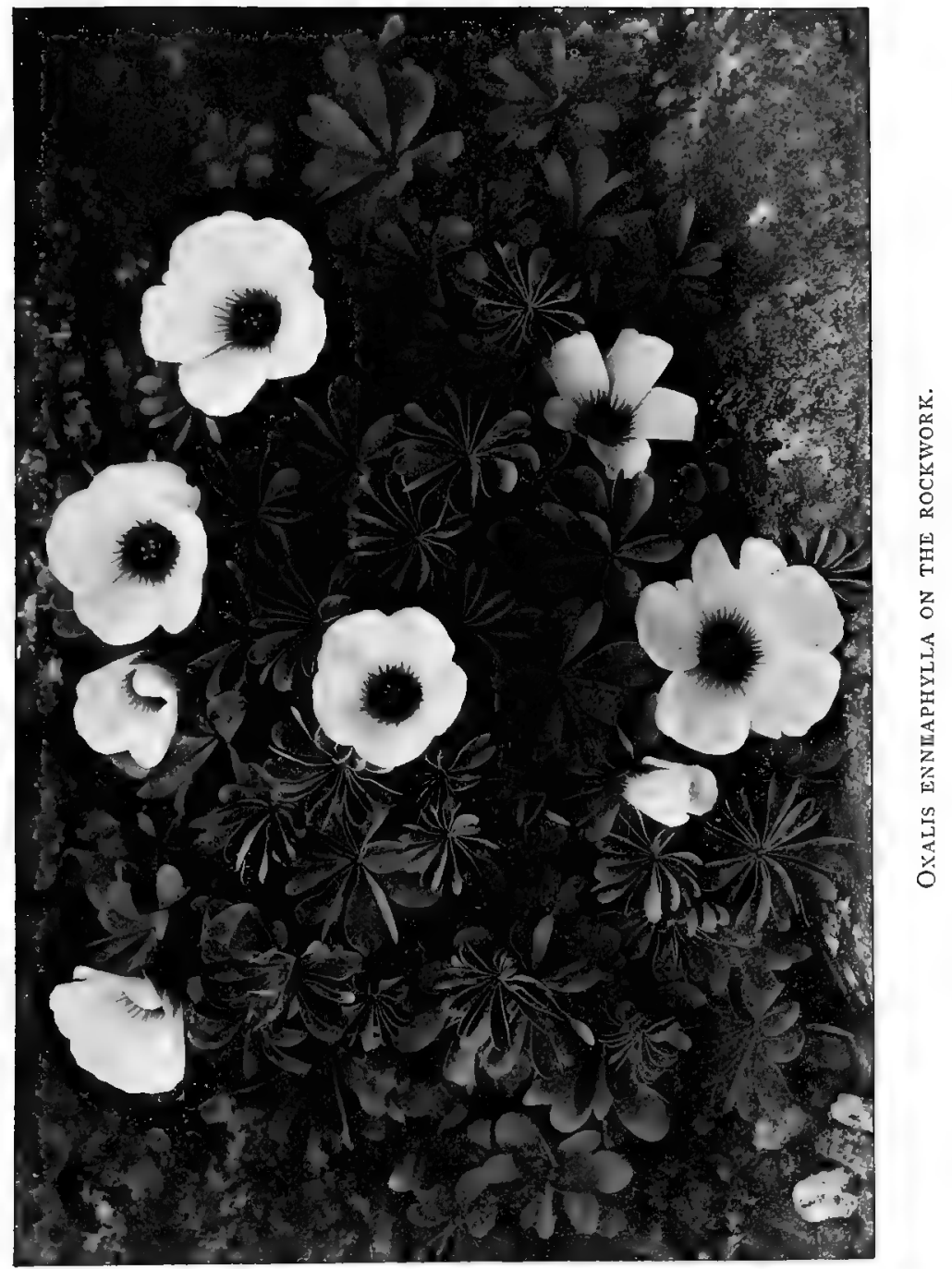





\section{BETWEEN DIANTHUS AND EPILOBIUM 109}

unfortunately it is a little delicate, and very much objects to damp. Also it is exceedingly difficult to procure; its range is limited; roots are not easy to come by ; and as for seed, the cattle browse so effectively over the high Alpine pastures where it grows, that very rarely after flowering-time can you find a sign of the plant itself, to say nothing of its seed-pods. No wonder it remains a rare plant of rigidly limited distribution. Perhaps the best of all, though, for the rock-work, is the new lovely hybrid, Cytisus kewensis, forming broad almost prostrate masses of long thin sprays, with pendulous cream-coloured flowers, large and beautiful. This is perfectly easy, hardy, and persistent, to be increased by cuttings; a picture of loveliness in its time. Procumbens and biflorus (biflorus, I fancy, is one parent of kewensis; and Ardoini may be the other) are rarities of kindred habit, bearing much the same cream-coloured blossoms, and having much the same creeping habit, though less vigorous, perhaps. Decumbens has golden flowers, and its synonym is Genista prostrata. Schiplaensis is a charming dwarf shrub with white flowers.

Of the greater Brooms, there is the dull lilac-pink NewZealander, Notospartium Carmichaeliae, for a warm corner, and then Cytisus praecox, the white-flowered, and Spartium junceum are invaluable for bold work. And all theseCytisus, Genista, Spartium-are of the easiest culture, though Cytisus Ardoini and his rocky kindred deserve, of course, more attention than the big rampers. A weird and curious beauty, though, of whom the same cannot be said, is Erinacea pungens; truly may this be called a hedgehog! It makes a microscopic bush, like a Broom dwarfed by a Japanese. Then, on the long, inexorable bare spines that make its boughs, there break a few apologetic-looking little leaves, and after these the large, deep-blue flowers. Erinacea is a Spaniard, and requires heat and drought, and rough well-drained soil, if it is to 
do well. It is a slow grower, and its synonym is Anthyllis Erinacea, a rare, difficult plant to get hold of, though now I have one very fine specimen firmly established in rich warm loam on a sheltered corner of a sunny bank.

The Rest-harrows make dwarf shrubs, and are coveted by many, though I myself have little enthusiasm for them. They are a little coarse and undistinguished to my taste, though their golden or rose-red flowers are undeniably effective. Fruticosa, Natrix and rotundifolia seem the best; and thrive in any good sunny place. To my mind, though, they have a good deal of leaf to not quite enough flower, as a rule.

Astragalus is a large race, containing many valueless weeds, and a few good things, of which Astragalus monspessulanus, with its variety albus, is almost the best. This Vetchling roams about on the ground, with handsome rose-crimson spikes of blossom. Ambigurs is a seedling of which I have great hopes. His foliage is pure silver, his habit neat and sub-shrubby. And his flower is to be rosy-pink. But he seems very slow to flower. Alpinus is handsome, but I have never possessed him. (With rare exceptions, I must say that the Papilionaceae don't excite in me any very keen interest.) Tragacanthus is a strange, thorny creature from the Mediterranean coasts, rather curious than lovely. Our own native trailer, though, Hypoglottis, is distinctly pretty, and I have just got seed, too, of an undescribed Astragalus mongolicus, on the usual gambler's blind chance of finding a beauty; but indeed, these Milk Vetches, for the most part, are coarse and dowdy plants. All, without exception, I believe, thrive in open, sandy, sunny places, and their finest species is Astragalus Vandasii, a rarity from Servia, loving a hot dry bank, and making a mass of prostrate branches, richly covered in the summer with spikes of brilliant rose-purple flowers. In his weedy order Astra- 


\section{BETWEEN DIANTHUS AND EPILOBIUM 111}

galus Vandasii takes a high place, so beautiful, yet so robust, and this without loss of delicacy, for his whole habit is ferny and graceful, and he never spreads from his one crown. ${ }^{1}$

The Woundworts, of whom we have a bright specimen in Anthyllis vulneraria, of any limestone down, are good, easy-going creatures, of whom the rosy Anthyllis montana is the best, though the pink and white forms of vulneraria sound delightful. But these I have never possessed.

Of the Clovers, the only one that can fitly enter the rock-garden is $T$. alpinum (my manager grows canescens with enthusiasm, but I think it gawky and dull); he is a dwarf trailer, with immense rosy flowers, very handsome, but so obstinately difficult to uproot that I have never yet got him satisfactorily acclimatised. You find him on the topmost ridges of the Alp, up to the edge of the moraine. And a beautiful strip of ground that is-soft and trim and firm as any tennis-court-a neat sward made up of nothing but flowers-Trifolium alpinum, tiny willows, Oxytropis montana, or pyrenaica, Silene acaulis, Azalea procumbens, Gentiana nivalis. Oxytropis is represented in gardens by some very lovely, ill-reputed species. Pyrenaica, montana, Halleri, and lapponica are all delightful dwarfs, with heads of brilliant blue-purple flowers. But they are found difficult to acclimatise. I have succeeded with montana and pyrenaica; the others have failed. Oxytropis campestris is taller, fluffy, woolly, and dull yellow, rather ugly, whose only interest is that he is found on one rock in the mountains near Braemar, in that prolific block of country which gives us also Saxifraga cernua and Saxifraga rivularis, Lactuca alpina, Gentiana nivalis, and Myosotis alpestris. Two North American Oxytropids are splendens and hybrida; hybrida seems

1 Astragalus Vandasii must lose marks; he is not genuinely hardy with me : at least he dwindles. 
weakly; but splendens appears a well-intentioned plant, with silky silver foliage and fine rosy spikes. The good species of this race want sun and well-drained lightish soil; as for the bad ones, nobody cares what they want.

The Lupines are notable sub-shrubs. Besides the noble Snow-Queen I grow some beautiful North-Americans. Lupinus decumbens has silky-silver leaves and lovely spikes of soft lilac flowers; almost equally good is argenteus. These trail about the rock-work in any light soil, and, to my joy, seem completely hardy and winterproof. As for Lupinus nootkatensis, I don't know if I have ever got the true species; all I can say is that if I have, it is not the thing that my soul covets. For my heart is set on a most exquisite, minute plant, making dense silvery cushions about four inches high, with spikes of big azureblue flowers, which grows here and there quite commonly in the highway-sides about Vancouver and Victoria. It was there I saw and loved it, and collected seed of it years ago. All the seed germinated; and then all the seedlings died. What that plant's name may really be I cannot tell; I merely guessed that nootkatensis might suit it, as belonging to that quarter of the world. I can only say that it is a very astonishingly lovely thing. Possibly it is a miff; all the Lupines, I think, dislike excessive damp. They must be well-drained, and rather dry, to be safe. As for the things I have been sent for nootkatensis, they are tall, coarse, and, by contrast with what I wanted, horrid.

Coronilla varia is a weed, only admissible to the wildest, roughest banks. And, even so, be careful to get a wellcoloured form. For while some Varias are of a brilliant warm rose, others, the majority, are of various dull and tepid tones. Coronilla emerus makes a stalwart bush of yellow blossom, and is not reputed quite hardy. Anyhow 
two wee seedlings I brought from Cannes a dozen years ago have so prospered without protection that now they are stately shrubs. Coronilla iberica is very different from this-a true rock-plant, neatly trailing, with glaucous-green leaves, and bright, bright golden flowers. All these are sun-lovers, for warm slopes and ledges-where also our own native Hippocrepis comosa is quite as pretty as anything the heart could desire.

Of the Hedysarums I have smooth things to say. They are willing and pretty and full of character (so many of these Butterflies lack individuality). Hedysarum obscurum is a dwarf plant, with silky clumps of leaves, and handsome heads of crimson; sibiricum and neglectum are similar, but, I am told, and hope to see from my seedlings, even prettier. Hedysarum multijugum is gracious and elegant, a slight shrub with graceful foliage, and brilliant purplishcrimson spikes; and $H$. Mackensii is another shrubby species from North America, whose growth, as my seedlings show it, is very promising, and whose flowers are well spoken of. All the species are of the easiest possible culture anywhere, though one would not put them too near the smaller, choicer Alpines.

Orobus, Vicia, and Lathyrus have made a sort of Witches' Cauldron of horticultural confusion. The Vetches may be left aside, though Vicia canescens (or something that has once borne that name) sounds very beautiful, if it were procurable. The glorious purple weed, too, Vicia Cracca, is a fine thing to have established in a wild spare corner, and even more exquisite is the frail, pale climber Vicia sylvatica, with spires of softest china blue-and-white. This I once found rioting in a glen near Scarborough, and collected seed of, but, alas! with no result. As for the rest, I have many seedlings of new sorts, but, of course, am as yet unable to decide on them. I grow Lathyrus latifolius albus with 
pleasure in a very rough place. The common Lathyrus pratensis is a beautiful yellow pest; and then there is a rose-red Lathyrus, possibly derived from tuberosus, bought years ago from Mr. John Wood, that trails about over my bushes in late summer, a coverlet of salmon-rose sprays. The smaller red tuberosus I have grown too, if it be still alive-that pretty little plant which is naturalised round Fyfield in Essex. Pubescens I once had seedlings of, but they very soon miffed off into a presumably happier world where the bad plants go to; and magellanicus, I fear, is only an annual, though it was glorious last year with its big sky-blue flowers. Surely it is the same as what I saw many years ago at Cannes, called Lathyrus azureus? I seem to remember the same huge, winged seed-pods. Orobus and Thermopsis are close cousins: Thermopsis with big orange or yellow flowers, Orobus with blue, yellow, rose or white. Orobus (or Lathyrus) vernus, our own native, is as beautiful as any -blue and pink and green, all on one plant; then there are varieties-white, salmon-and-white, double-white, and so on-all lovely. The nearest to this is niger, almost indistinguishable, but interesting as being native to one glen in Scotland. Then comes Orobus lathyroeides, and the yellow luteus and the orange-tawny aurantiacus. All these, and others too, are well worth having, and very easy to grow in any open ground. Unlike the rocklovers and the general run of Southern Butterflies, Orobus and Lathyrus, though disliking stagnant moisture, are far more patient of ordinary open-border conditions than most of their kindred. Thermopsis fabacea and Thermopsis rhombifolia are tall, stout Orobuses with greenyellow flowers - the one European, the other North American, and good for any place where they can have room. But of this group (unless you can get hold of Lathyrus cyaneus) the best and finest are Orobus hirsutus, and 


\section{BETWEEN DIANTHUS AND EPILOBIUM 115}

Orobus varius. 'These are both plants of imperturbable vigour and hardiness, growing persistently, thriftily on, in any decent position, even in the open border. Hirsutus forms a prostrate flopping mass of foliage, covered all through the summer with a profusion of single winecoloured and purple flowers, like big violets. Varius, erect, slender, graceful, grows about a foot high, has fine delicate leaves and loose spikes of the loveliest blossoms, clear-white and salmon-rose, that appear in early summer.

The Potentillas are beloved by many, but not by me. In fact, I can muster no love for any Potentilla over six inches high. Hippiana, pulcherrima, argyrophylla, and the rest have all been tried, conscientiously admired, and secretly disliked. Brilliant as they may be, to me they seem coarse and leafy. However, $I$ hope better things from fulgens, which has just been given me with high recommendations. And splendens is small and pretty-a silver strawberry. These Potentillas have such marvellous names, all of them - pulcherrima, formosa, argentea, chrysocraspeda, crinita - you expect something after that; pulcherrima ought to be at least pretty. And no authoritative work ever describes these people either, so that when one is working over a catalogue, one has to go by these awe-inspiring adjectives, and order the plants they belong to, in the hope that they may not be liars, these sonorous epithets. But they generally are. Potentilla nitida, however, is certainly a jewel-I seize the opportunity of repeating its praises-well worthy of its comparatively modest but truthful name. Other beauties are the natives verna and alpestris, the double form of that awful weed, reptans, the silvery Valderia, and a nameless little white ramper I collected in the Rockies. Otherwise the long lists of names that swell out Potentilla in catalogues are too apt to be tall or dowdy plants. The 
real jewels of the race (besides nitida) are two Himâlyans, ambigua, a dwarf runner, with abundance of big golden flowers; and Tongui, frailer, but no less vigorous and hardy, even in the open ground, with larger flowers of blended salmon and yellow, recalling the pure and subtle tones of the Tramonto Rose as you see it on the Ligurian Riviera.

Of the closely kindred Geums, I have already told of the dwarf glories, reptans and montanum. Suffice it here to say that our own North countryman, rivale, with pendulous rosy purple bells, is very pretty, but soon seeds itself into a perfect pest; bulgaricum is a fraud, with huge flannelly leaves, and dull flower-heads of a ghostly lemon colour. Heldreichi and aurantiacum are taller (and therefore by me less beloved) orange-red forms of montanum. Remains only rhaeticum, a gem too long misprized. Rhaeticum, so robust as to be even a border plant, grows tall and slender, with graceful leaves; and bears wide loose heads of large flowers, so brilliant, so golden, that times without number I have mistaken my plant from afar for fine specimens of Linum flarum. Until rhaeticum flowered I looked askance on my seedlings, disliking gawks; now the plant has come by its own, I make amends; I know few things more bright and lovely.

As for Waldsteinia geoeides, this is next door to a Potentilla, and would be a Potentilla in any less sophisticated age. It runs about wildly all over the place in any rough ground, no matter how weedy, and bears abundance of pretty yellow flowers in early spring. The Strawberries, too, are Potentillas in nearly everything but name, and the wild Strawberry is always a welcome visitor on my rougher slopes, where its fruits shine temptingly upon the wayfarer as he wends up the steep treacherous steps. Fragaria lucida has lively big white flowers and shiny leaves, while Fragaria indica is a yellow-flowered trailer; 


\section{BETWEEN DIANTHUS AND EPILOBIUM 117}

and the Plymouth Strawberry has odd greenery-yallery flower-like bracts or petals gone wrong, and is evidently what Parkinson recommends a gentlewoman to wear on her sleeve as a curiosity, instead of an ordinary 'tussiemussie.' 


\section{CHAPTER V I}

\section{Jrom Epilobium on through $\mathbb{a m b e l l i f e r a e ~}$ and Compagítae}

As for the big Epilobiums, our native Hirsutum (the Codlins and Cream of river-banks) can only be described, from the gardener's point of view, as a devilish invention. Once, many years ago, in my innocence, I admitted hirsutum to the Old Garden. No decent words can express the torments that $I$ have suffered from that horrible plant ever since. Its great white root-stems go louping along underground, and when you have massacred the shoots that have appeared above, you haven't nearly accounted for all the dreadful energies that are still lurking underneath. I leave it to fellow-sufferers, or afflicted gardeners generally, to imagine my misery. And the same must be said, too, of Epilobium angustifolium, with its splendid magenta-crimson spikes. This is a gorgeous wilding, but it is madness to allow it even into the wild garden, unless you are prepared to give it a free hand. The only other Epilobium I have to tell of is a wee New Zealand creeper that I first saw at Miss Willmott's, and afterwards possessed. It has thyme-like leaves, beautifully variegated with silver, and charming little white flowers. Unfortunately it does not seem to be very hardy. At least I cannot discover any sign of life in any of my frame-plants, so that I have but little hope unless April brings forth a miracle. ${ }^{1}$

${ }^{1}$ No; no miracle ; this Epilobium is a half-hardy. 
'The Evening Primroses, beautiful as they are, are not among my greatest successes. A drier climate, lighter soil, and quicker drainage would probably make these Americans happier. I have tried the pink-white speciosa again and again (could there be a lovelier thing than this, or its variety rosea?), but never with any permanent good luck. A wet winter overcomes it, and I never see any more of it. Serrulata, however, seems a trustworthy plant here; unfortunately I cannot care much for it. I think its abundant yellow flowers rather small and mean. Missouriensis, rightly a herbaceous species, prostrate, with enormous yellow blossoms, is really and honestly and enduringly prosperous here, which gives me much to be thankful for. Youngi is good, too, and thrives; Howardi, stout seedlings, has made haste to depart.

It is a rare thing to come upon an attractive plant among the Umbelliferae. But Dondia Epipactis is a pleasant plant by reason of its quaintness. In early spring it sends up its glossy sanicle-like leaves, and then, on a three-inch stem, above the leaves, a queer, little inconspicuous head of yellow flowers. Dondia prospers anywhere, but, being small and meek in habit, should have a choice corner, where he may be trusted not to get into mischief. Of the larger Umbellifers few can come into the rock-garden, though on very bold constructions our native Myrrhis odorata, with vast fern-like fronds, is very handsome indeed; while the giant Fennels and Heracleums (Ferula Linki and Heracleum mantegazzianum especially) should also find a place.

The Sea-Hollies, with their steely blue leaves and flowers, are so well known and such useful border-plants, that one need hardly describe them or prescribe them. But I cherished in the moraine-garden one exquisite and rare little Sea-Holly, who never seems to grow more than four inches high or so, with small spiny leaves, and bluey- 
gold flower-heads. Eryngium glaciale, in defiance of its name, is a Spaniard, and, I believe, very seldom seen. It was given to me by a kind gardener near Carnforth, where it throve in rather a casual place on the rock-work, and gave fertile seed. I, misled by its minute appearance and glacial name, planted it reverently in the moraine. However, it did not take this misguided attention amiss, for it unfolded its little tufts as complacently as ever-until ultimately, alas! a slug made, in one night, an utter end of Eryngium and all my joy together.

The true Eryngium alpinum and its form superbum are really the very best of the ordinary Sea-Hollies-rare plants rather, in the Alps, though I have once seen the type above St. Martin Vesubie. Its huge frilly blue collar and solid blue flower-head, topping the broidered blue and silver foliage, give it a Byzantine beauty; other good kinds, though not better, are Bourgati, planifolium, and Olivieri. As for the Pandanus-leaved sectionpandanifolium and Serra and so forth, no persuasion can make me think them anything but ugly,-with their enormous yucca-like leaves, and their mean little tiny dull flower-heads on stout promising stems. However, as 'Formes architecturales' for bold landscape gardening these plants no doubt have a value. Only not in the rock-garden. As for the pretty little Bupleurums, with their umbels of golden buttercup-like blossoms, I have never been able either to collect them successfully hitherto or to raise them from seed. And, with them expires, $I$ think, the possibilities of the Umbrella-bearers.

The small scattered orders that intervene between the great horticultural Sahara of Umbelliferae, and the greater horticultural Sahara of Compositae, give us a good many valuable things. In the first place, Araliaceae gives us (beside the minute and fascinating miniature ivy, Hedera minima) the magnificent 'Udo,' Aralia cordata, a common 
Japanese vegetable (they eat the young shoots, boiled like Asparagus), one of the most superbient of hardy herbaceous foliage plants, growing eight feet high or more in the season, with rich, Ailantus-like foliage, and quite splendid for any bold commanding point. Aralia japonica and Aralia Sieboldii ought to be used in the same way. For certainly, if you get them from anywhere near Tokio, they must necessarily be as hardy as daisies.

Asperula Athoa rejoices in many aliases : some call it suberosa, some athoa, some arcadiensis. At least I have received one species, always, under these three names. I like best to think of it as fellow-countryman to Arcadian Atalanta, snowy-souled, though often, in my garden, must the plant have repeated its compatriot's plaint:

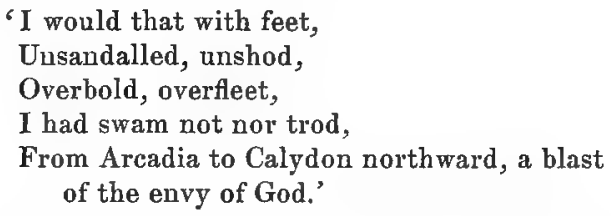

For no matter in how warm, light, and well-drained a nook you may place this frail southerner, it is always liable to suffer from winter damps. Not for many summers in succession will you see those brittle little greyish branches, crowned with their profusion of long rosy trumpets. However, my plants are now breaking more robustly than ever, and, if the slugs can be warned off, will soon be stronger clumps than before. So that care and cosseting have this time availed. And who need grudge them to Asperula Athoa? Other pretty Woodruffs are our two natives, cynanchica and odorata, the first for high and dry places, the other most admissible to a low, unprofitable corner out of harm's way. And close to these comes the dainty American Bluets, Houstonia coerulea, only a few inches high, with pale blue stars all the summer through. 
But this, alas! is rather a miff, I don't know why. Others may well be luckier than I; but here I have never really established either coerulea or serpyllifolia, although I remember how at Kirkstall they grew about under bushes, in dank ground, just like the commonest of cresses.

Many Valerians are frequently advertised in flaming terms. I have now bought most of them, in hopes to find a pretty one; but I never have. I think they are invariably, big and little, rather coarse dowdy plants. Arizonica was warmly recommended; celtica had a sentimental interest; rotundifolia was described as attractive. But they are every one of them disappointing, with a good deal of leaf and then dull flattish mounds of very poor pinky-purply flowers. No more Valerians for me, then, please! One species, dioica, I think, has little whitish flower-heads that cover all the wet places about here, and iniquitously annoy me when I go questing for white forms of Primula farinosa, perpetually luring me from afar with their general suggestion of an Albino Primula, and then when I have scrambled up or down the hill after them, mocking me with their nasty anæmic Valerianfaces. Almost every rare plant has a sort of protective Double, I find, who deludes one, and embitters one's search. When I ransacked the Devil's Kitchen above Llyn Idwal for Lloydia serotina, there were innumerable nameless little white things that kept putting me off and setting my heart in a flutter; in the high Alps one is perpetually shinning up cliffs after Eritrichium, only to discover Myosotis rupicola, or darting after a white Gentian, only to find some irritating Mountain Chrysanthemum or Camomile.

As for Scabious and Teasle, they do not give us very much. When we get to them we are close under the shadow of Compositae, and the curse of coarseness that blights our largest race of flowering plants falls also on 
the orders nearest to it. But Pterocephalus (or Scabiosa) Parnassi is a neat and very pretty little Eastern Alpine, with mounds of greyish leaves, and purply Scabious flowers hovering freely over them on short stems. Another Pterocephalus which I tried from seed has not turned out very well. The Scabiouses themselves are useful rather than distinguished. But caucasica is certainly pretty, and so is japonica, in a bold way, with big flowers of a really lovely soft lavender-blue.

In all the world there is not another such enormous race as that of the Composite Flowers, whose three branches are aptly typified by three of our commonest weeds, the Daisy, the Dandelion and the Thistle-so that when even Mr. Robinson admits that in this family one has to wade through 'innumerable gawky weeds' before coming to any good garden species, it will be understood how low stands the general level of beauty in this vast and unprofitable clan. Weeds are the Compositae, one and almost all; and as weeds they will flourish one and all in any open reasonable treatment. If any plant has to be excepted from this rule of easy culture, it will almost always be on account of some fad about climate.

But, if the generality of Composites are dull, graceless, and stupid, the comparatively few species that have merit have a good deal. Let me not be thought ungrateful or flippant about the beauties of the beautiful Composites. When you get them they nearly redeem, and quite obliterate, one's memory of their plain relations. Of useful plants in this race Aster alpinus, I think, easily heads the list. And a vast number of Asters, I must first record, are coarse leafy things, washy and poor in colour, and rank in growth. But the brilliant ones are brilliant indeed. I have a great love for Aster pyrenaeus. And then there are species like cassiarabicus, kabulicus, Fremonti, and Townsendi-medium kinds, pleasant and 
useful-Fremonti especially notable from its large, rosypurple blossoms. Kabulicus is a woody shrub, and bears rather pallid stars. Cassiarabicus proves magnificent, a far more bushy, voluminous, and brilliant Amellus with profusion of big, deep-purple blooms. Townsendi is a synonym of Bigelovii, a handsome lilac biennial. Aster latifolius and Aster canescens are rare, and more usually known as Machaerantha-the one is glabrous and leafy, the other silky grey; both bear large gorgeous blossoms in varying shades of Imperial violet. Canescens, though it has survived the winter, is of rather frail, bienniallooking habit, with one main stem that seems as if it will only throw lateral growths as a matter of exceptional courtesy ; Latifolius is more genuinely perennial, but both are American species and like warm light soil, with very effectual drainage and as much sun as possible. I have tried to believe in their hardiness, but they won't allow me.

Another pretty American is Fendleri, which has made no great impression on my mind, while yet another Yankee, Porteri, is a very great friend of mine, neat, light, and feathery in growth, with showers of small snowy stars-a robust little plant of exemplary grace and beauty. Aster diplostephioeides is an obscure species, so far doubtfully in cultivation. I have seedlings of it on good authority, which I hope may prove true, but the plant which has been sold for it of late years is the true Aster sub-coeruleus, a species no less valuable and very similar, the main difference lying in the colour of the eye-florets, which in sub-coeruleus are golden, and in diplostephioeides bluish. Aster sub-coeruleus makes masses of handsome foliage in big rosettes, and then, in June, sends up a number of naked stems about a foot high or more, each carrying one very large bright violet flower. It is thus an edition-de-luxe of alpinus, even more vigorous and less slug-haunted. As for the better- 
known border Asters-especially the littler ones, and things like ereicoeides and dumosus and their varietiesthey need hardly be recommended.

My own joy among the larger Asters is acris, with its fleecy cloud-masses of soft purple, lying across the upper garden like a mist of colour through late summer and autumn. Acris I remember in the south of France, a wiry-leaved dry-ground plant, with abundance of tiny ragged flowers, inexpressibly airy and delightful. In cultivation it never gets coarse, but blossoms with wild generosity, and divides endlessly in spring. I have just got a roseus and an albus variety-but without any hope that they can possibly surpass, or even equal, the fairylike type. Aster Linosyris is a graceful native, distinguished by abundant yellow flowers, from which there is now a hybrid Asterolinosyris Willmottiae, which I have hastened to procure, feeling hopeful that so high and august a name would not be lavished on an undeserving plant (yet what of Iris reillmottiana and Lilium Burbanki?). Aster sibiricus I have had for years, without ever having much affection for; so far I have found him a medium-sized plant, but a rampant spreader, with large but rather ragged and ineffective deep-lilac flowers.

After Aster may come their miniatures the Daisies. The Swiss giant Daisy, Bellidiastrum Michelii, I have grown and lost and never replaced. It is a huge version of the common Daisy, and not, I thought, worth any extravagant fuss. Then there is the so-called blue Morocco-Daisy, like our own, but more graceful, and with flowers in varying shades of very pale blue. This lovely little creature is unmistakably half-hardy hereat least has always proved so in all the positions we have ever tried for it, though in light, hot soils in southern gardens it may be more persevering. Bellis sylvestris I have doubts of. Under this name $I$ have grown on from 
seed a fat, stalwart plant, exactly like a fine common species, but with flowers which, though on some specimens indistinguishable from the ordinary Daisy, are on others of a bright crimson. Now I know the true sylvestris is said to be red-flowered, but the question is whether my plant, considering its reversions to the ordinary whites of Bellis perennis, is more than an unusually bright-coloured strain of the common Daisy. Bellium minutum is the treasure of this group-a wee, wee plant, like a Daisy looked at through the wrong end of a telescope-a most fascinating miniature of a thing. This is a rare Levantine, and is delicate unless you give him a dry, hot corner, with the sharpest possible drainage.

The Alpine Yarrows and Camomiles are plants I am rather conscientious about than enthusiastic. 'Too often, as in Achillea atrata, and its congeners, the white is of an unworthy, dirty tone; even in moschata and the purer colours, the white is apt to be very hard and dead and cold. There is something, too, a little weedy and ill-bred about the look of the plants-an astonishing thing for species so high-Alpine. But Clavennae and Jaborneggi and Kellereri are really beautiful-each with silver-white leaves and heads of more or less brilliant blossoms. Achillea serbica is a rare new plant, forming mats of grey-leaved branches and large flowers of a rather cold grey-white. But, among my importation bloomed one most lovely silver-leaved plant with larger flowers, pure and snowy. I hope to see more of this, if the winter has not alienated him beyond reconciliation. As for the larger Yarrows, honestly, I find them all 'gawky weeds.' Mongolica and ptarmica, 'the Pearl,' are very well for a rough border, so, perhaps, is the red version of the common millefolium-if you do not dread the risk of a possible pest. But as a class, these plants are far too coarse for the choice rock-garden, and not beautiful 


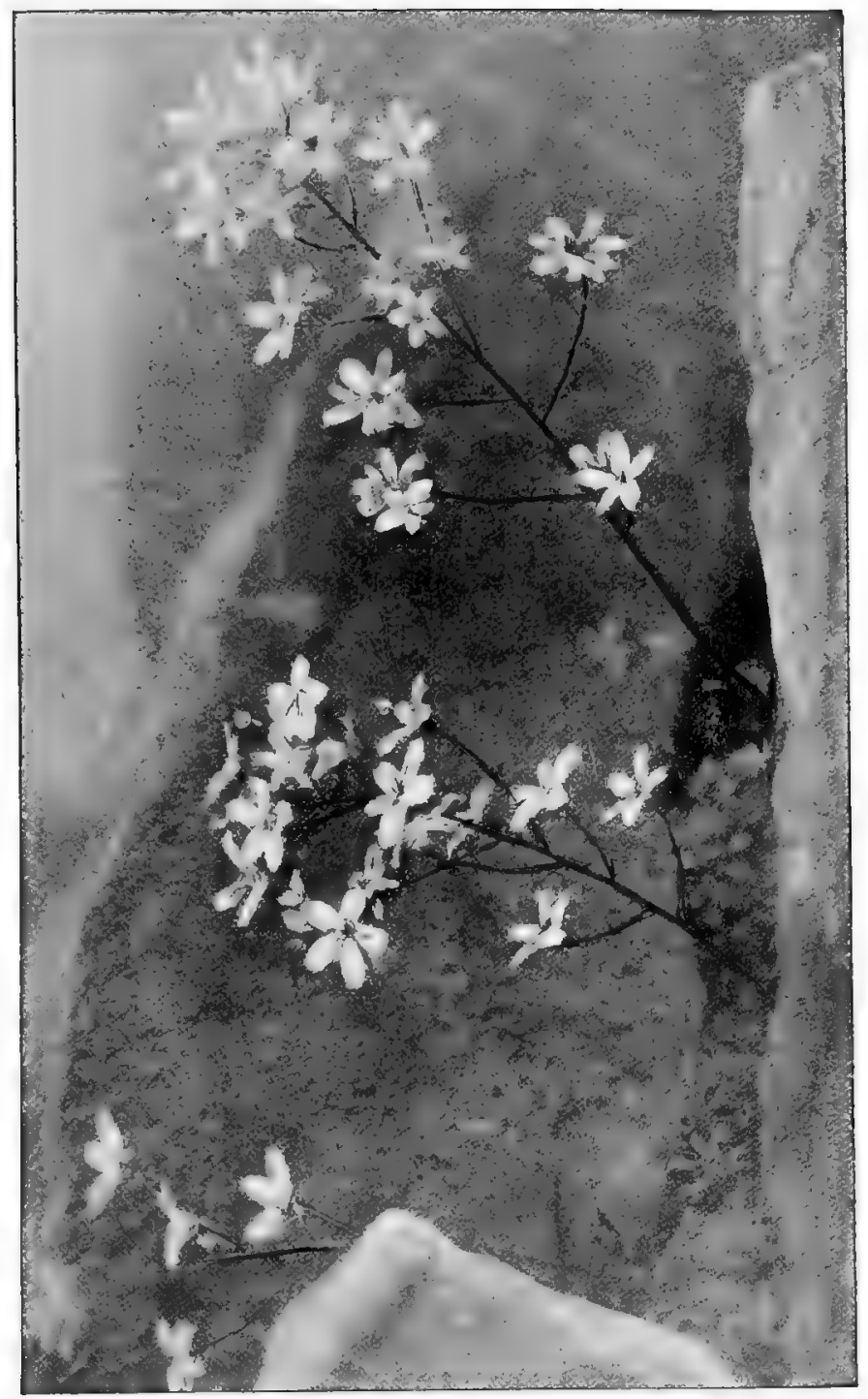

"Children of The Mist."

Saxifraga Burnati and Saxifraga cochlearis. 

enough even for the higher wilder banks. I imported sericea with a great deal of excitement one year from the East, but it turned out a huge, silky-leaved, goldenflowered edition of the common Yarrow. But of Achillea the name is legion; learned catalogues are swelled out with columns of them. I have no inclination to specialise on this race, and I am sceptical as to the beauty or distinctness of many of those recorded-however an Achilleaenthusiast, if any such there be, must go bravely on experimenting, in hopes to acquire unsuspected loveliness. So far as I know, all the Yarrows are easy to grow, though perhaps the glacial sorts may give trouble.

Close to Achillea, and only a little more attractive, are the Alpine Camomiles. Anthemis aeizöon, I must heartily acknowledge, is a very beautiful plant indeed, with rosettes of silver-white-pinnate leaves, and abundance of pure, snowy Marguerites, large and brilliant. Biebersteini is an Oriental, rather coarser, with big yellow flowers, that everybody else seems to admire a great deal more than I can. This race, again, looms large in catalogues; but I have never found an Anthemis to beat aeizöon, so perfectly easy and hardy that it is a pleasure to sit and look at its silver cushions. Pyrethrum is a race more famous in borders than in the rock-garden, but $I$ have (or had, for the winter seems to have killed it), a Pyrethrum densum, neat and pretty, with lovely silver-woollypinnate leaves and dull yellow flowers; while Pyrethrum transylvanicum is so new here that I can only commend its beautiful white foliage and pretty habit. Chamaemelon caucasicum is a ferny-leaved trailing little cousin of the Camomiles, with white Camomile flowers, not by any means particularly attractive or remarkable. Chrysogonum virginianum is a very free-growing $\mathrm{d}$ warf plant, with abundance of golden yellow flowers, which I have never been able to help thinking rather mean in colour and 
build. However it is an easy doer, and a favourite with many people, though it no longer finds a place on my rock-gardens. Amphiocarpus Neumeyeri is a strange hardy plant-and where I got it I do not know. Its attraction is the tuft of oval-pointed silver leaves; the small flowers, when they come, are rather dowdy. The Antennarias are best represented by our own precious little native, Antennaria dioica - a creeping weed, but very valuable for a waste bank, with small hoary leaves and chaffy little heads of white or rose-pink like a wee everlasting.

Of the Thistles, what gardener wants to be reminded? 'Infandum, regina, jubes renovare dolorem.' I once, regardless of wisdom and warnings, had Carduus eriophorus, from seed collected on cliffs near Scarborough; but this giant of his race died out after flowering, and $I$ have never replaced him, fearful lest a worse thing befall me. For, of the two alternatives, reproduction or extinction, the gardener will certainly be thankful for extinction where most of the Thistles are concerned. The one exception is Onopordon bracteatum, who sins in the opposite direction. For Onopordon bracteatum-so beautiful that there is no need ever again to think of any other Onopordon, makes huge rosettes of crinkled spiny leaves, brilliant silver grey, with veins of pure silver. And when the vast candelabra of rather inferior purple flowers has been sent up and matured, the whole thing dies, and there are you, planté là, with the Onopordon to raise again from the very beginning from seed. However, for high, bold places on the rock-work, Onopordon is eminently worth the trouble; and his seed has, at least, the virtue of germinating freely.

Carduncellus is a wee thing, like a small blue-purple Thistle, quite close to the ground, who is attractive in any barren place; while Carlina acaulis is a very beautiful Alpine, which you will see in August and September, all 
over the sunny, dry pastures-its wide silver and white blossoms lying tight on their thorny rosettes, and looking like Water-lilies of silver tissue. In cultivation, however, the plant wants quite poor, miserable soil or else it gets coarse, developing a stem, and enlarging its leaves at the cost of its brilliancy. The variety acanthifolia $I$ have always thought much less fine, for the same reason-that it is stalky, and not stemless. Our own Carlina vulgaris is near these two, but lacks the whiteness of blossom. The Saussureas look like little blue Thistles that have been packed up in cotton wool and got it inextricably twined among their flowers. They are not all distinct, but the one I grow as candicans is distinctly pretty. As for Cacalia and Brickellia, I mention them here merely as warnings. I bought them on the most flaring descriptions from America, and I can solemnly affirm that as far as my own taste goes, I do not think that even England produces two more totally graceless, dingy, overgrown weeds than Cacatia tuberosa and Brickellia grandiflora-this last, especially, of a dowdy gawkiness beyond expression: and even more tragic is my tale of Myrrhiactis Wallichi, which I got seed of from the Himâlya, and grew on in a perfect flutter of excitement, foreseeing promise of marvellous beauty, in its name-for surely nothing named for Wallich could be poor. Myrrhiactis prospered like a weed-whole framefuls of little pots. At last its innumerable flower-stems swelled up and budded. Then the flowers opened. They were like small groundsel-blossoms, with the outer rays entirely omitted. Myrrhiactis departed over the garden wall.

The big blue Ball-Thistles are rather border- than rock-garden plants; however, I rejoice over Echinops ruthenicus in a bold corner; and now am expecting even better things from my seedlings of the dwarfer-growing Echinops humilis. Another huge great plant is Silphium 
terebinthinaceum. If any one is bold enough to order this, they will find it handsome, with very tall stems carrying big Helianthus-like flowers, while the leaves at the base of the plant are fine and effective. However, it is not a patch on a good Helianthus, I must confess. Of the Rudbeckias I don't grow any more now-ever since I was irritated by Lepachys columnaris, which had futile, pale yellow daisies, with a silly sort of snout cocking up in the middle. The Mulgediums or Giant Lettuces are very splendid things though-to be admitted with caution into the garden. The biggest and most robustious is Mulgedium Plumieri, which nothing can hold in bounds. $\mathrm{He}$ is a glorious wild-garden, or rough bank plant, devouring yards and yards each season, and covering them with big hairy leaves whose underside is rusty purple. Then, in August, up go the stout flower stems six or eight feet high, carrying heads of blossom like large violet Dandelions. My thianshanicum is similar, but bluer in flower, and much milder in growth, forming a nice, neat, glossy clump, that never seems to spread about or grow greedy.

But the prettiest Mulgedium in my garden is Bourgaei, which makes one dense crown that gets denser and denser every season without any further spread. The abundant flowers are smaller than those of Plumieri, and carried in long lax sheaves. Their colour is of a peculiarly delicate and beautiful rosy blue-very gentle and soft, yet quite pure and decided in tone. Prenanthes is a quaint thing, vaguely recalling a starved Mulgedium, but even more like an Oat which, by some strange miracle, has developed tiny violet flowers. This queer creature inhabits all the Swiss mountain woods, and neither my manager nor I profess any wild affection for it; however, it deserves my gratitude for the happy way in which it has taken possession of a very barren place under a Laurus Tinus in 
the Old Garden-above whose glossy leaves its little purplish clouds come hovering indomitably each July. Adenostyles marks a doubt in my mind. I believe that the plant I got with great effort from shady rocks near Rosenlaui is not, as I had always thought, an Adenostyles, but really the true Mulgedium alpinum, a beautiful tall plant, with blue Dandelion flowers, of which Plumieri is an exaggerated variety. As for the genuine Adenostyles -the stout pink thing, with triangular leaves, white underneath, that you find in the high pastures of Switzerland, is Adenostyles alpina - not a very interesting species, and one that $I$ have never bothered to collect-while the only plant of the Dandelion group I have ever liked is the white form of the common Dandelion itself, which grows all over Tokio to the exclusion of the yellow type. Now I have seed of this, and hope it may prove true.

Of the Centaureas very few are really beautiful, I think, though several are interesting for sterile banks. Montana is quite useful thus, in all its varieties, and I grow also rutaefolia - a straggler, with whitish leaves and pretty, red flowers; and also another white plant, ragusina compacta. The Golden Rods, to me, are all coarse and quite unworthy of culture, without exception; and the Hawk weeds, even, though pretty, are too dangerous to admit. But valdepilosum is attractive, and so is aurantiacum, but a dreadful irrepressible weed. 


\section{CHAPTER VII \\ DDE SDd Treaguteg}

LET others specialise on Sedum and Sempervivum. I frankly confess that I approach these two great races with hesitation. I have never been able to take more than a mild fancy for even the prettiest of Sedums. Justice must be done, though, even if deliberately, and I will place it solemnly on my record that the average Stonecrops are useful, easy-going inhabitants of the rockery, if kept in due bounds. Having said so much I will add my own personal sentiment, which is the same for Sedum as for Draba-a mere recognition of merit, uncoupled with any warmer feeling. The Stonecrops nearly all thrive anywhere, and are typical rock-plants, with the one exception of our own dear little marsh plant, the most charming species of the family-Sedum villosum, found in small colonies here and there in wet places on the high moors round the base of Ingleborough. Sedum album has white flowerheads, and is a rare native of attractive appearance. It turns out an appalling weed, which one throws away in cartloads without ever succeeding in eradicating (my whole stock sprang from two crushed sprigs sent me in a letter : two years later I was weeding up barrow-loads of it without effect). Sedum anglicum is another rare little native, much neater and smaller, white-flowered and of modest habit and glaucousblue leaves-perhaps the prettiest of all Sedums for 
the rock-garden. We may also include Sedum dasyphyllum, and Sedum brevifolium, a really beautiful tiny species, with fat blue foliage. (Pottsi is the name under which I had this, but what Pottsi may mean, or who Potts is-unless he is the unique gentleman who said he admired Johnson's Irene,-I have no notion.)

Equally pretty are my Sedum lydium and my S. Ezersi turkestanicum, this last rather larger, prostrate, with ovate, variegated leaves and pretty pink heads. Corsicum is neat, and supposed to be a form of dasyphyllum, and farinosum a form of album. Rhodanthum and aeizöon I am growing on from seed. But the larger Stonecrops lack individuality in my mind-they are furniture rather than inhabitants of the garden.

Of the larger Sedums Ingleborough provides me with Sedum Rhodiola, the herbaceous Rose-root, with stout woody root-stock, and stiff' stems of glaucous leafage and dull yellow flowers. The name comes from the scent of the root, which, in the wild plants, is like that of an old Damask rose. Sedum spurium, a prostrate mass, with broad heads of white and pink, ramps in every cottagegarden; Sedum kamschaticum, with a variegated form, is virtually an orange-coloured spurium; Sedum Telephium, with tall, dingy crimson heads, is a useful, uninteresting native; Sedum spectabile, with its enormous blue leaves and ample cauliflowers of rosy blossom in late autumn is equally familiar. It is a splendid thing, beloved of bees and butterflies, though its colour has a chalky tone that makes it perfectly ghastly anywhere within a mile of any good crimson, scarlet, or yellow. Sedum sexangulare and Sedum rupestre are natives, the first common, and the second extremely rare, but not easily distinguishable from each other; both thrive on any wall, and have heads of golden flowers which, in the similar Sedum pulchellum, are of a soft pink. Unfortunately Sedum pulchellım, otherwise 
a very attractive kind-seem to have a biennial constitution, or at all events a tendency to miff away. Sedum oregonum and Sedum spathulatum are closely relatedınedium-sized plants, distinctly attractive, with glaucous or glossy spathulate leaves, which in the splendens-forms of oregonum, are of a gorgeous blood-red. And, in conclusion, I must disclaim any authority for the names I give. They are reported as I have had them; I believe them to be trustworthy, but I have never yet specialised on the Sedums, and I think it unlikely that I ever shall.

The same may be said of Sempervioum-but in a very different, sad, contrite spirit. If I were certain of two hundred years of life, I would begin specialising on the Sempervivums to-morrow. But one's life is short, and one's horticultural interests many. It is not possible to run so many horses abreast!-if there were room in one's days for all one's enthusiasms, I would specialise on Iris, Tulip, Lily, Sempervivum, Saxifrage, Odontoglossum, Gentian, Primula, and goodness knows how many charmers more all at once. But, as things stand, a wretched writer of books, who is also a worshipper of Orchids, as well as a slave of the plants, and an amateur of all stray expensive lovelinesses to boot, must perforce put a rein on some, at least, of his possible fanaticisms; for, if pain follows on desire as certainly as the wheel follows the foot of the ox that draws the cart, so do bills inexorably dog the path of all who let themselves be snared by the delight of the eyes. Therefore I will hasten on past Sempervivum with a shamefaced, sidelong glance, adding nothing to what I said earlier, apropos of $S$. arachnoideum.

I have already dealt with the small Phyteumas, but there are some of the larger kinds which come well into the garden.

The others most desirable are Charmelii, Scheuchzeri, and orbiculare. Of these I pin most of my affection to 
Scheuchzeri, a neat, thrifty thing, about a foot high or so, with round heads of deep blue bottles. The others are similar, but a trifle less distinguished. All these plants are very easy to deal with, and, I think, prefer rather moister treatment than the others, in shady corners of the rock-work. My best Scheuchzeri was collected by me once, without my knowledge, in a clump of Anemone narcissiflora that I consoled myself with one barren dreary afternoon on the Schynige Platte above Interlaken. It was already late autumn, and everything was over, and all the mountain-panorama was cold and cloudy and grey. But I saw the Anemone's leaves, and made good the lost day by grubbing him up. And when the clump was well-established in the old garden, lo and behold, it consisted not only of the Anemone but also of Phyteuma Scheuchzeri, Geranium sylvaticum, and the little Snow-Crocus. Now for many years they have been fighting the matter out between them, and I am inclined to put my money on the Phyteuma, which seems to be crowding the others out one by one. The Geranium will very likely go soon; the Crocus, I believe, has gone; the Anemone shall never go, if I have to redress the balance of the world by making an artificial clearing in the midst of the Phyteuma. ${ }^{1}$

As for Phyteuma orbiculare, his round heads of deep blue on their tall stems may be seen here and there in our south-country meadows. On the Ruff above Abinger, for instance, he grows all over the place-nor need one have any scruple about saying so, for, first of all, the plant abounds there, and, in the second, the man, nor the million men, have not yet been born, who could eradicate a flourishing Phyteuma. Such a silly name to

${ }^{1}$ Latest news : The Phyteuma has abruptly, irrelevantly expired, like Salammbo, in the very hour of victory : the Geranium and the Anemone now have to fight an internecine duel. 
give the poor things-just The Plant! As for the Michauxias (how can an ordinary person be expected to pronounce this?-'Me-show-ia' is right, but is beyond most people; the name usually emerges as My-corks-ia), they are tall things, more or less biennial, with panicles of reflexed flowers like tiny blue Panther lilies in general effect. Campanuloeides has not done much good, but Michauxia T'chihatchezi (there's the worst name in the garden) is a handsome-leaved grey person, who thrives persistently in a warm, well-drained nook; both are easterners, hating mould.

The Thrifts are rather respectable than beautiful. Tall, giant Armeria Cephalotes is very splendid if you get him in a good shade of pink, bright and warm. For he varies in colour, from seed, and, besides, is more than a little of a miff-dying out suddenly under a heavy rain, if your climate be chilly and wet, or your soil too heavy. However, while he lives he thrives heartily, and so escapes the reproach of being a mimp. For a miff is a plant which, in the midst of seeming life, is in death, and expires abruptly; a mimp is one that for ever hangs on the edge of death, trailing a sickly existence towards inevitable extinction. Thus Gentiana verna in too many gardens is a mimp; Myosotis rupicola is a miff. Of the other Thrifts, the only one to trouble with is Armeria caespitosa, a tiny, furry little ball from blazing rock-clefts in Provence, thickly covered, in spring, with globes of pale rosy flowers. This is lovely, if not brilliant, but wants careful watching, perfect drainage, and a warm, dry corner where damp may never lodge round its crown. Our own Armeria plantaginea is a dull, reduced edition of Cephalotes, and any varieties advertised as brighter are certain to be only of a more tedious because more pronounced magenta than the type.

The Acantholimons, however, are the most delightful of 
plants in every way-neat and thrifty and brilliantcousins of the pallid Thrifts though they be. Probably the old glumaceum remains the best-making mats of spiny cushions in any decent, hot place, and then sending up spikes of bright rosy blossoms, like very large thriftflowers, each arranged singly, in a chaffy bract. My other species, venustum and androsaceum, are much rarer in gardens, and even more beautiful, though slower in growth, and, perhaps, a little choicer in requirements. The leaves of venustum are glaucous grey, and the flowers are much bigger than those of glumaceum, and of a lovely bright pink; the flowers of androsaceum have more purple. All the Acantholimons hail from hot ranges like Lebanon, and in cultivation like a sunny-corner, light soil, and a high, well-drained position; in which circumstances they show themselves pleasantly hardy and accommodating.

Two other sun-lovers with whom, on the contrary, I have had a good deal of bother, are those two glorified Portulacas, Lewisia rediviva and Lewisia Trweedyi. These are both Americans, and want sun and drought and drainage, so that I might have expected difficulty with them. However, rediviva has done very fairly well, with its odd habit - a reminiscence of the deadly desertsummer, I suppose-of dying off most wretchedly into a withered mass, and then (just when you are on the point of throwing away the corpse in disgust) of breaking quite happily again, with a quantity of rosy Mesembryanthemum-like flowers. Lervisia Treeedyi is very much more beautiful, however, with leafy rosettes, that look like some succulent evening Primrose, and then, on stems about four or five inches high, large flowers of an iridescent creamy-pink, such as you see in certain Tea Roses. In the open this plant has been an utter failure here-any touch of undue damp seeming to rot its stout 
fleshy root-stock immediately. Nor, to console myself, do I imagine that many people in England are so favoured as to find Lewisia Treedyi a really sound, trustworthy, outdoor plant. For pots, perhaps; but for the rockgarden it is useless to cope with plants who fly beyond any mere soil-requirement, and want you to alter the entire climate of the country before they' 'll condescend to thrive.

Primula, Gentiana, and Androsace are races far too great to be huddled together without distinct and definite treatment, but they each have a number of smaller clans dependent on them, which give us a few good and one or two brilliant plants. The Cyclamens come first, of course, and what uninitiated person is there who would believe that these are reckoned cousins-german to Primula? They don't need detailed discussion, although so charming, so I will only say that autumn-blooming Cyclamen europaeum is the most delightful of plants for naturalising in light, loose woodland, while Cyclamen repandum is very bright among the toughest grasses, with its fine flowers of a rather fierce magenta-crimson. The most beautiful of all, to my mind, is the new and very rare Cyclamen libanoticum-a dear little plant of the large-flowered, spring-blooming section, with beautiful fleshy leaves, and abundance of big, fragrant, peachy-pink blossoms-a treasure from high glens of Libanos, which prospers with me in sheltered places under Cistus Laurifolius and big Daphnes. Cyclamen coum, the wee winter-bloomer, I have never cared for-the flowers are so preposterously small and dull; nor have I collected Cyclamens long enough for any discussion of the many confusing names that fog the race; europaeum, neapolitanum, and hederaefolium being all very close together, if not mere varieties or synonyms; while vernum does duty for repandum, and ibericum with its form Atkinsi are twins to coum. 
A very difficult thing to establish, as far as my experience goes, is the rare and dainty Chickweed Winter Green, Trientalis europaea, which I collected once, very carefully and perfectly (it is quite easy to collect), from woods in East Yorkshire. And yet, though given every care, those plants never did any good with me, and all subsequent attempts to grow Trientalis europaea, or its stronger brother americana, resulted in dead failure. And then, two years ago, where no Trientalis was or should have been, up a Trientalis came, full in the middle of my big Pyrola rotundifolia. Now, had it lain dormant in the clump ever since the Pyrola was collected-or was it simply a wandering little white sheep from the black flock of Trientalis that had all died off years before? And, if so, what had persuaded it to better thoughts, or made it take shelter under the wing of Pyrola, where I had never dreamt of putting it? And, now that it has come, it reappears again each season, and always stronger than before. Trientalis is so very pretty that I earnestly hope he will always continue coming-a whorl of small, rounded, glossy leaves on a five-inch stem, and then, springing up on even frailer foot-stalks, one or two starry, white flowers, rather like a fairyfied Chickweed, as its common name implies.

The cousinship of the Primulas closes here (for Anagallis tenella belongs to the bog), and, before I go on to the relations of the Gentians, I must make the amende honorable to two or three plants that $\mathrm{I}$ had forgotten. The first of these is Eriogyna pectinata, a tiny, trailing collateral of the Saxifrages, who, with fine, ferny foliage, throws long rooting runners about in shady corners of the rock-work, with small spikes of blossom like tiny spiraeas. Then comes Convolvulus : be very wary of that loveliest and worst of weeds, C. arvensis, whose rosy, wide trumpets may plead with you for a welcome. Admit it : in 
a year your soil will be packed tight with the matted macaroni of its dreadful roots, and you will never, never be clear of it again, for it is worse than Goutweed, worse than Willow-herb, worse even than Coltsfoot itself. Convolvulus Soldanella, from our own shingles, has not made any show here; and, saddest tale of all, mauritanicus, fragile trailer, with wreaths of azure megaphones, is not of certain hardiness here, though eleven miles off, in Westmoreland, plants from my own garden mock at me by their brilliant persistence. Yet again, more beautiful than even this must be that very notable rock-plant C. sabatius, found only in one place in the whole worldbetween the crannies of the Cape of Nola, on the Riviera. Here also, and here only, lives Campanula floribunda, and I have never possessed either. However, let us hope the Campanula has no special merit, enters into no rivalry with my two prized novelties, raddeana and amabilis. Raddeana has proved itself a perfect jewel-lovely, delicate, exquisite, with showers of purple hairbells, and a charming, persistent habit of increasing from year to year. Amabilis is much larger, pleasant as its name; a stout rosette, with three foot spires, loose and graceful, of big shallow cups, soft blue, with a dark purple eye.

Of the Acanthuses I have the latifolius varjety of mollis, the most splendid of all foliage plants, not excepting the huge Gunneras and Giant Rhubarbs. But mollis is not quite happy here, at least not as rampant as in rather softer places. In Westmoreland and the Lakecountry, that soaking Himâlya-paradise for the gardener, it makes glorious glossy banks, which are as admirable as anything I know. Here it thrives quite sufficiently, but not, so far, with any wild enthusiasm. However, the Acanthus needs time to estublish himself, so I still nourish hope. Then I have Candelabrum, reputed a fine, sturdy kind, and a dwarf species called roseus, Perringi, or Caroli 
Alexandri. This is hardy and vigorous, quite small and low in leaf, with a very stodgy, important-looking spike of pinkish flowers about a foot high or more. Except for its quaintness and rarity, I do not think this a very wonderful plant; it has not the choice brilliancy of an Alpine, while it has lost the tropical grandeur of the typical Acanthus.

Glossocomia, Codonopsis, and Cyananthus are cousins of the Campanulas, which deserve a place to themselves. I will not pretend to distinguish between the indistinguishable Glossocomia and Codonopsis. They are flaccid, rather loose-growing herbaceous things, with nodding, big bells of blossom, which vary infinitely from one packet of seed; the prettiest, very pretty indeed, of a soft green-blue, witl brilliant, many-coloured gold and blue markings inside. The most frequently grown plant is called ovata, but I believe the true ovata is very rare in cultivation, and I am anxiously awaiting flowers from the seed of it that was given me last season. Then there are two or three other species or forms, of which I am rearing seedlings, of viridiflora, ussuriensis, and Tang-sheng. They are all quite hardy, and ought to be planted high, high up on the rockery, so that their pendent bells with the quaint interior markings can nod down at you in all their delicate beauty.

And now we come to a. race indispensable beyond all other indispensables for the rock-garden. For who will deny this claim to the dwarf Phloxes, to the innumerable cheerful family of setosa and subulata? Of the species I grew caroliniana, a vigorous trailer that runs about all over the place, in any ordinary loam, sending up heads of rosy pink flower, large and bright even in the late autumn, after a gorgeous display in the spring. Pilosa and Douglasi are rather rare, sand-loving plants, very pretty and choice, but not making any attempt to rival 
subulata in vigour or effectiveness. Stellaria is a beautiful lax trailer, like a rather large subulata, making mossy cascades down the rock-work, with abundance of very pale French-grey flowers - a delicate, soft shade extremely attractive. The form erubescens I cannot quite place in my memory. I do not think it can be any improvement on Stellaria.

Amoena and pretty ovata, as far as my garden knows them, are both bright and pleasant little plants, creeping and ramping over the ground, though I cannot at present accurately and definitely be certain which is really which, and how they are each distinguished (if at all) from the other. One dwarf Phlox that I have as nivalis is a wonder of loveliness-close to Nelsoni, that snowy carpetmarvel, and actually sustaining the comparison. And, very similar, to be distinguished only by their rivalry in beauty, are all those matchless garden-carpets, the children of subulata-Daisy Hill, Vivid, lilacina, annulata, and the countless other sisters of Nelsoni. My favourite of all, perhaps, is the beautiful Phlox divaricata-a medium-habited thing, making a bush about a foot or eighteen inches (dwarfer and more compact in Perry's Laphami-form of the synonymous canadensis). The flowers are very large, like Periwinkles in size and colour and shape, borne in wide loose heads, and scented exactly like Lilium auratum. The cool, soft blue of this Phlox makes the most glorious contrast imaginable with the ardent splendour of the orange-vermilion Double Welsh Poppy. And the Phlox is as vigorous and easy as the Poppy with which it goes so well. In colour it has a rival in subulata $G$. F. Wilson (or lilacina), a fine rug of moss, which is covered in early summer with such a multitude of clear, electric-blue stars that all other Subulata Phloxes are put to shame, and even Nelsoni has to look to its laurels. But Phlox Vivid, though small- 
flowered, has blossoms of a rich, hot, salmon-scarlet, and, combined with the moonlit blue of $G$. F. Wilson and the snowy chastity of Nelsoni, makes an unsurpassable tricolour of the most subtle yet blazing beauty-the more so that the other rosy Pluloxes have a taint of magenta.

The large Natural Order of the Borages provides me with a good number of easy things and a good number of difficult ones too. To deal with the worst of these first-there is only one Lithospermum, so far as I can discover, that is really and truly a limestone plant. Alas that I have never had the chance of proving Lithospermum erythrorhizon, whose big round flowers make the copses below Nikko into the reflection of a cloudless sky at dawn! Lithospermum graminifolium grows here very affably, but too many of the others pine and languish, even if $I$ give them peat-soil and all the luxuries that heart can desire. Among the languishers is azure prostratum-rich in colour as any Gentian-that is such a Meibuts' of sandy, Surrey gardens; as well as petraeum and the dazzling, half-hardy rosmarinifolium from sunbaked sea-cliffs by Amalfi - so that of their beauty, therefore, I dare not trust myself to tell, lest, like the bereaved Achilles, I should speak the unhusbanded truth, and melt into wild lamentations. But graminifolium is a very dear and gracious plant, with many prostrate branches, each terminating in a grassy rosette that sends up in June a nodding head of lovely pale blue, tubular flowers-in fact, though this plant has not the awful brilliancy of the celestial Lithospermums, I console myself by believing that it has even more tenderness of charm. And the way it grows is a pure joy.

With intermedium, a hybrid, I believe, of graminifolium, I have had success; the lovely Gastoni does well here; and purpureo-coeruleum, the rare Welsh native, is a fine ramping thing, which has, at last, I don't know why, died 
out with me after firmly refusing to flower through many years of luxuriant growth. I first collected its big heads of sapphire trumpets in a copse near Cannes, and in many a cool, shady glen of Liguria will you come unexpectedly on its glory of blue. To my surprise, the American yellow Lithospermums have been a moderate success with me-multiflorum, canescens, longiflorum, and hirtum making herbaceous, sturdy little bushes, with abundance of golden blossoms, in any light, sunny place. Add to these the lovely common Prophet-flower, with its blackspotted, canary-yellow blooms like big cowslips, produced perpetually - and the Lithospermums, with their cousins, do not do so badly by me after all;- and Arnebia echioeides is one of the most brilliant of easy beauties for either border or rock-work, in any rich soil, well-drained.

The Onosmas are opulent hairy creatures, with white, golden, or crimson bugles, that hang from the uncurling, crozier-like spikes. They are all Southerners, peering down from the ruins of Byzantine castles or Saracenic fortifications, and, it stands to reason, hairiness and habitat considered, are quite unsuited to a cool, wet climate. However, the best of all, the well-known Golden Drop, Onosma tauricum, is very satisfactory here, and even more so, of course, in gardens that rejoice in a drier, colder winter. Glorious, indeed, is a mass of this all through the summer, with up-curling spikes thick hung with long drops of pure amber. Similar is the white form, but more delicate; as also is rare Onosma albo-roseum, whose bells are of white and pink-a lovely, tender plant. Of Onosma Thurberi and $O$. Thompsoni I speak doubtfully. I flowered $O$. Thurberi last year and found it a fraud-a biennial, with a stout, podgy spike, set with dull little red flowers.

of the remaining Borages the true Lungworts never move me to much enthusiasm. The Spotted Dog or 
Jerusalem Cowslip of cottage gardens I even dislike, with its liverish-looking leaves, and its feeble, purply-red flowers. But the unspotted variety, azurea, with deep sky-blue flowers, is beautiful; and so is our own very rare native Pulmonaria angustifolia, which I collected years ago in Dorsetshire woods-a plant of slight growth, with narrow, spotted foliage and large flowers of a very rich pure sapphire. Then there is a pretty blueflowered arvernensis, and a white variety which is smallblossomed and dowdy in effect; while Pulmonaria rubra, despite the real charm and brilliancy of its rosy bells, must be looked after and frequently divided if it is to be kept floriferous and showy. And, even so, it has rather too much leaf as compared with the flowers. However, it is very pretty, and all the Pulmonarias bloom while the garden is still rather dead and sere; so, for this, as well as for their invariable good temper, we must love and cherish them, as well as two near relatives of theirs, Cynoglossum apenninum and Cynoglossum pictum, with showers of bright blossom, sound, sturdy growers for a backward corner, where such splendid things as the Dropmore variety of the Italian Anchusa can be put.

Of all inconsiderable and dowdy weeds the Fig-worts are the least worthy to give their name to a very large race, which, while it is more generous in larger than in small plants, is yet of great importance in the rock-garden; for, though, setting aside Linaria, Pentstemon, and Veronica, there are no big clans of brilliant plants among the Scrophularinae, yet there are a certain number of valuable species cropping up here and there by themselves. Otherwise this Order leads worthily on to the dull desolation of Labiatae, though I know this is an unpopular view to take, and that nowadays it is good form to say that all plants are lovely, and that Nature can never be either dull or plain. However, one must abide by one's 
own convictions, and I will honestly say that Nature not only can be both, but very frequently chooses to be so ; so that real treasures are in an inconsiderable minority. As for the exalted truth that the emancipated mind can see beauties in Groundsel or Deaduettle, not for one moment will I deny it. But its prophets in popular literature seem too often to speak academically, as worshippers of the ideal, rather than as horticulturists with actual earthly, earthy gardens to cultivate; and as my book, no less than my garden, aims at dealing simply with the cultivation of obviously beautiful, interesting plants, I will reverently waive aside for the time this abstract doctrine of immanent, universal beauty, and content myself with the concrete, everyday beauty as the everyday garden can fitly contain it. The blessed Elizabeth actually talks about the "loveliness of Cow-Parsley, that most spiritual of weeds.' But had Elizabeth ever tried CowParsley in her German garden? I think not. Nor, to do her justice, would she, I believe, claim to admire it out of its place. So, thank goodness, we are really at one.

The noble family among the Fig-worts is undoubtedly that of the Pentstemons. 'These are all, as far as I know, Americans, and range from north to south, from hill to valley, from leafy coarseness to the extremest and most delicate beauty. Many, too, hailing from countries where the sterner winters are what we should call a warm July, prove sad and unhappy in our gardens. But both beautiful and happy, even with me, is bushy $\boldsymbol{P}$. Scouleri, with profusion of large pale purple snapdragons. But far more beautiful than this, almost lovelier than anything else I know, is my latest novelty Pentstemon heterophyllus. This is a slender, graceful grower reaching perhaps to eighteen inches. The foliage is ty and refined; the flowers appear from July onwards, in very loose, elegant spires- 
and their colour! Imagine long narrow bugles of a tender soft violet, and then lip and hood and open throat all of the clearest, purest azure blue-blue as a Gentian or a Myosotis. The tone in itself is a glory; the combination is a very miracle. And, planted out everywhere, in all places and conditions of good drainage and light warm soil, the Pentstemon bids fair to show itself a sound, hearty perennial, breaking anew (at least we hope so) each season from the base.

Of the larger Mimulus I can never muster much love for cupraeus or for cardinalis; cardinalis appears to me to have flowers quite inadequate in size for the robust leafiness of the plant; while there is somethingshape, or shade, about the blossoms of cupraeus that never quite appeals to me, though it makes a gorgeous show round my pond in August. But our native or naturalised alien, Mimulus luteus, with his big yellow, brown-freckled Gloxinias, well deserves one's affection. Even more deserving are two most splendid dwarf-growing hybrids, Brilliant and Model, of which Brilliant is of a flaming velvety crimson scarlet, while Model, even more lovely in my eyes, is of the hottest possible salmonrose. Both these make carpets round my pond, and are a perfect blaze of glory all the summer, not to mention that they pull to pieces and propagate heartily from the smallest fragments. Then, of the little ones, there is the neat, dainty yellow-flowered Langsdorffi from the Rockies, and two minute species, radicans and primuloeides, mountaineers from wet places, I fancy, of which radicans has violet and white flowers, and primuloeides abundance of small yellow ones. They both creep and shrink along the ground-and, either I have been away during their great days-or else they have never had any great days; at all events my impressions of them are not by any means striking. 
Of the Snapdragons, those who wish can naturalise Antirrhinum majus in any or all of its forms on sunny rocks; I content myself with several less showy yet equally pretty southerners-asarinum, sempervirens, and glutinosum. Of these asarinum has fleshy, trailing stems, with large, soft, rounded leaves and a quantity of big creamy Snapdragons nestling among them, while sempervirens and glutinosum make stiffish little bushes among the rocks, with quantities of smaller blossoms along their small-leaved, greyish branches. These are all lovers of drought and sun; therefore of doubtful hardiness in many parts of England. But these half-hardies, as the lady says of English women in 'Le Monde où l'on s'ennuie,' 'ont d'aimables surprises,' and I, who had always found sempervirens and glutinosum dead after an average winter, am now overwhelmed with astonishment to see that they have sailed triumphantly through the monstrous inclemencies of $1906-7$, and are breaking up into vigorous little masses once again. Asarinum I planted high and dry; and yet I have known some incalculable survivals here and there in the dampest, dankest, most unpromising places.

Linaria anticaria is a pretty dwarf thing, rather like a much magnified Linaria alpina, with flowers which vary infinitely from seed-some being dowdy and quite unworthy, while others are very fascinating-white and velvety brown. Linaria repens is abundant on the walls of Oxford and elsewhere, a tall plant with very long close spikes of tiny purple flowers. This plant is only admissible into the roughest wilds, for it ramps most grievously and makes itself quite a nuisance. Its variety $a l b a$ has rather larger flowers, set more loosely on shorter spikes, and altogether is much slighter in growth and more graceful in effect. But even this should be used with caution. Linaria dalmatica and Linaria dalmatica 


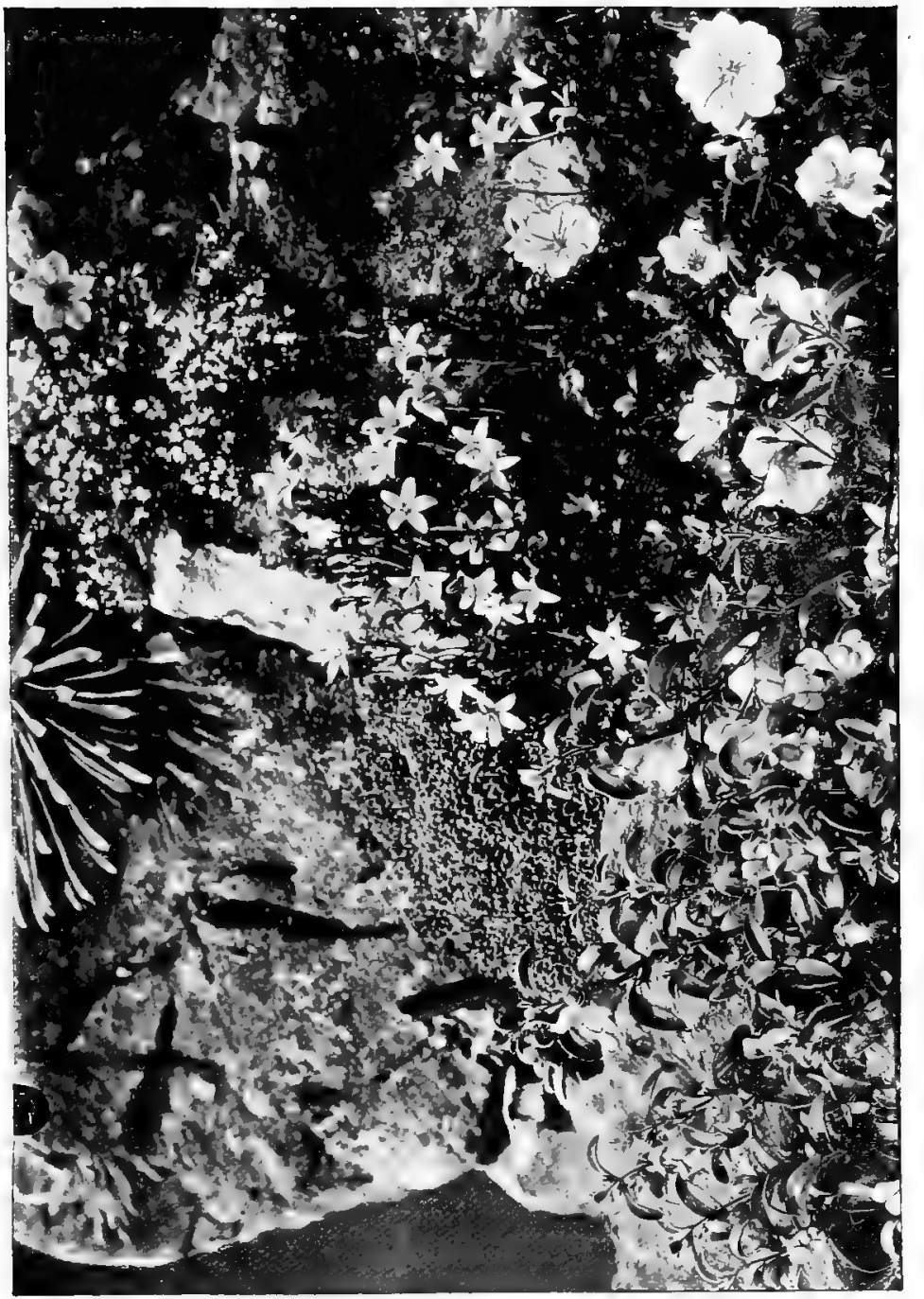

告 

macedonica are magnificent herbaceous plants, broad and narrow-leaved forms of one type, probably, like enormous common sulphur and orange Toadflaxes, with glaucous leaves and a sturdy upstanding habit, that make bushes four feet high or so, and flower all through the summer, and thrive in any decent position as heartily as any one could desire. Linaria Cymbalaria is our own dear little creeping Toadflax of the walls, which is charming for any neglected corner, as well as its bigger, more brilliant pallida form. As for Linaria hepaticaefolia, I have an uncertain plant which came to me as Linaria ovata, but which is declared to be the true hepaticaefolia-a creeper, with round, white-veined leaves, and large whitish lilac Howers, admirable for a rough, shady corner, like every creeping Tordflax. But one must be very careful with all of them; for, if you give them an inch, and they like it, they will certainly go on to take an ell; only the most valueless wastes should be allotted them; and I already foresee that I shall have trouble with my hepaticaefolia, which is beginning to run up a choice cliff at whose dank base it was planted in certainty that it would be out of all harm's way. Linaria Cymbalaria maxima, and Linaria Pancici-this last a novelty and wellspoken of-are yet but seedlings that will flower this season. As for Mazus rugosus, that also is a seedling, but looks so flourishing and flowered so prettily last year, with little Toadflaxy blossoms, that I am in high hope he may prove more satisfactorily winter-hard than the older and better-known Mazus Pumilio. And another pretty little plant of the Fig-worts, Coris monspeliensis, a Provençal, with six-inch spikes or so of small purple and gold fowers; this, like the southerly Antirrhinums, blooms long and late, loves dry heat, and is not safely hardy here, except on a high-drained corner of the rocks in light soil.

Foxgloves and Mulleins are hardly rock-plants, except 
for high, rough banks, so I will only chronicle my pretty yellow-spiked Digitalis ambigua that I collected many years ago in shady dells of the Esterel ; and a very beautiful ambigua hybrid of which I have seedlings. The parent-plant had close small-flowered spikes of lovely rosy bells. 'Then for the Verbascums I am reduced to the pretty phoeniceum, with flowers that vary through almost every conceivable shade of purple. Decorum I once imported from Servia, but he was very flannelly and very like the common Mullein, so that what with one thing and the other, I experienced no wild regret or surprise when the whole lot mouldered off as a consequence of damp on the journey.

From thought of the Mulleins, so rank, so coarse, I leap with pleasure to the contemplation of my tinier bulbs. Not here is the place, nor am I the temerarious soul to talk of Daffodils, of wee Daffodils, of Narcissus nanus, Bulbocodium, monophyllus, calathinus, triandrus, moschatus, and many another delicate angel of springčapos äry praising the 'pied Fritillary.' Difficult, indeed, are some of these, and dowdy, but I worship the white variety of our native Meleagris; and this is a thrifty soul that goes ahead in any decent soil. Aurea is perfectly beautiful, with the same rounded bells, but much dwarfer, and of a soft canary-yellow, faintly checkered with more or less brown. Armena is another pretty one, and so is Moggridgei; but the dingy ones like pyrenaica I consider dull and ugly ; while pluriflora, with the scarlet flowers, has never done much good here, and, altogether, it is in pots rather than in the open that $I$ get my pleasure out of Fritillaria. The Erythroniums, however (why are they called Red Violets or Dog-tooth Violets, or any violets at all? Nothing could be so unlike), approve of me more warmly, and are always perfectly beautiful, with 
marbled leaves as with yellow or pink or white reflexing flowers. They are spattered all over the place, and thrive heartily-Americanum, Howelli, Dens canis, revolutum, and Stuarti (the true lovely white montanum I have never been able to get).

Little bulbs uncountable does the cousinhood of the Lilies give one, and Grape-Hyacinths are among the prettiest. I have never specialised on any of these families; so my Muscaris are restricted to ordinary ones, like the very heavenly Heavenly Blue, whose turquoise spikes are almost the earliest flowers to appear; then there is szovitzianum, with its white and its rare pale azure form; and the common botryoeides, with our own native racemosum, all little cluster Hyacinths, these, to whom my love goes out far more readily than to plumy, wild monstrosities like comosum.

Of the Hyacinths, my prime favourite is the soft, skyblue amethystinus-a real sky-blue, with its white form -as well as the ordinary Dutch Hyacinth, when it has forgotten its Dutchness and grown thin and elegant again, in which reduced and reclaimed condition there is not a prettier plant alive than the Hyacinth that had been so fat and horrid and soulless the year before, in beds or pots or glasses. Hyacinthella rumelica is a novelty that I am rearing from seed, and whether it is pretty or no I cannot say - at this moment I cannot even tell you whether it is alive or not. All I do know is, that if a thing with such a name can be ugly, I shall no longer believe that there is any sense of decency in nature.

High, high among bulbs comes our well-known Bluebell, too, and on this subject I must loose my wrath against the purblindness of people who, when they want to naturalise Bluebells, don't buy our own Scilla nutans, but the kindred Scilla patula (or campanulata or hispanica), which is a Bluebell spoiled at every point, with- 
out the grace, the charm, the refinement, or any other delectable quality of Scilla nutans. The one advantage of patula is that it is certainly easier to establish than the Bluebell, who is not always very adaptable. But, oh dear me! the advantage is dearly bought; and surely it is worth the extra trouble to have a thing so infinitely superior as is Scilla mutans to Scilla patula. One year, too, I found in the woods, and collected with immense care, a Bluebell who had immense pale blue bracts under each bell, so that the whole spike looked like a head of bearded barley that had got dipped into Heaven by mistake. Although this was taken up in flower and with a penknife, it has continued to thrive and increase mightily, till now I have quite a colony of my little Paderewski Squill. The other Squills, so far as I grow them, are not very brilliant or interesting, except my Scilla sibirica, of course, whose colour is of such an awful squalling blue that it brings the water into one's eyes to look at it.

The Chionodoxas, though, are all charming-Alleni, Tmolusi, and Lucitiae; while of the Snowdrops my vote, in this mixed, vexed race, goes solely and passionately to Galanthus Ikariae and Galanthus poculiformis. My Ikariae is out and away the largest and most brilliant Snowdrop I have ever seen, while poculiformis, only a little less in size, has its inner segments pure white and like the outer ones, but smaller, so that the flower looks like a reversed snowy chalice without a single spoiling touch of green. Otherwise all the Snowdrops are to me rather cold and dreadful-icy, freezing flowers, hardly flowers at all, but emanations of the winter, in whom I can take no real joy except on a very bright or vel'y muggy day that gives a hope of spring. The Snowflakes are different somehow, though vernum and carpaticum bloom almost as early in the year. Carpaticum, indeed, blossoms with the Snowdrops, and its dark green tufts, with the big, 
pendent flowers, purely, warmly white, with their orange markings, are to me far more heartening than any Galanthus that ever sent up gelid-looking leaves and opened its cold-coloured frost-flowers. Leucoium aestivum is only less valuable than his earlier relations because he comes at a less lonely time, when such as he are less prized, and the exquisite Leucoium autumnale (or Acis autumnalis), the Pink Snowdrop from Gibraltar and the South, has never done any good here. Those Southerly creatures don't; I once had a present of the very rare Narcissus viridiflorus from Gibraltar, but nothing more ever came of it, despite attentions beyond number. 


\section{CHAPTER VIII}

\section{The 2 Big $2 B a g$ and itg Illitieg}

The denizens of the bog-garden, large and small, have, as a rule, one distinguishing tendency which sets them far apart from the inhabitants of rock and crevice. For their habit is, either not to thrive at all, or else to prosper so outrageously that they eat you out of house and home. And this second alternative, fortunately, is that usually chosen by bog-plants, with the result that the bog-garden is one of the enthusiast's easiest domains-giving him the maximum of joy and glory, with the minimum of pain and worry. Indeed, among the larger bog-plants there are hardly any that can fairly be called difficult or illtempered, but a large and opulent generosity of growth is their prevailing characteristic.

In the first place, about the building of the bog-garden. The prime, dominant, inevitable, necessity of the boggarden is the most perfect drainage. For, the more moisture a plant requires, the more imperiously does it require that the moisture shall drain away and be renewed incessantly. It is a fatal error to imagine that because a plant enjoys growing with its feet in water, and its fibres a-soak with perpetual wet, that therefore it cannot need drainage. Too often the error is made, and the boggarden, built to retain the moisture, becomes a slough of soured and soggy mud, in which the roots of all but the most rampageous weeds turn sick and die. Drainage, 
sharp and rapid, is even more essential for the inhabitants of the marsh than for the pinched children of the high rocks. One only has to study their circumstances. In the soaking, fine shingle of the last moraines grow the downy-leaved mats of Androsace glacialis; and one concludes that heavy, loitering damp can, despite probabilities, be no enemy to that roseate loveliness. But, if you examine, you will see that the moisture is perpetually running, sifting, drifting through the rough harsh sand, and never rests for a minute round the roots of the Androsace. It is true that $\mathrm{I}$ have chosen, for my instance, a plant so difficult of culture that no treatment seems to satisfy it; but my rule holds securely and firm all through the long list of bog-plants, from Ranunculus glacialis, a-glitter in the melting streams of the snow-beds, to Campanula hederacea, twining its tiny peal of azure bells through the long wet grasses of North Wales. (And yet I have just heard of a plant of Eritrichium nanum-Eritrichium nanum, if you please!-which has thriven unprotected through a phenomenally rainy winter, planted in a low boggy hollow! Oh dear me, there is only one infallible rule, I believe, in the culture of difficult plants; put them elaborately, with full precautions, in a corner carefully thought out to suit their requirements-and they 'll certainly die; plant them where, by all laws of their being it is physically impossible for them to survive-and they 'll probably go ahead like Duckweed on a pond. I think I must take to growing Eritrichium as an aquatic, and Miltonia Roezlii as a hardy perennial.)

In building the bog-garden, then, take all the soil out, if necessary, to a depth of three feet or more, then set a bottom of very rough drainage before you put in your rich mixture of loam, peat, and old manure. Obviously such a violent course is not always necessary, by any means. Quite often your garden will be founded on sharp 
gravel, or flow down a salutary slope. But wherever your soil is retentive, it will always be wisest to give the garden a fair start by preparing the ground thoroughly beforehand, and arming it against catastrophes. Your ultimate success will trebly and quadruply repay your initial trouble. Never scant initial trouble, never despise it. Half the world's horticultural tragedies arise because gardeners, for one reason or another, fail to make their preparations complete, fail to be thorough with the long, tiresome, and sometimes expensive preparatory measures. Neglect initial precautions, save a few sixpences in the matter of drainage, concrete or what not, when you are making your garden, and you will certainly have to spend many sad laborious years, and many unprofitable pounds, in trying vainly to make good your own deficiencies, to do, with difficulty and pain, what might and should have been done properly and easily at first. For it is never easy to make good an error; a thing obvious and simple to do in its own good time, becomes difficult and dreadful to accomplish when its time has gone by ; and very rarely, with great trouble and misery, can one ever catch up the lost years, and make a tardy botch of what should have been a simple, workmanly job in the earliest beginning of one's scheme.

I speak all this feelingly; I was seduced, in the faroff years when I was making the Old Garden, and worrying, through my own ignorance, into saving labour here, and saving labour there, into allowing thoroughness of work to pass as insignificant, into yielding to various pernicious 'dodges,' because they were cheap. Result: the Old Garden for years has been a sore burden, an unrewarding toil, a daughter of the horseleech in its rapacity. Money in floods has been poured down its bottomless gullet of late seasons, in a vain effort to reclaim it; and it is only now, after ten struggling years of failure, that the thing 
is turning into a success. And that is only by girding me heroically to the task, and undoing every inch and every yard of all that was ever done before, and rebuilding the whole thing from the very foundations, as it ought to have been done at the beginning, nearly a dozen years ago. And, had I done so, I should have saved incalculably, in money, time, labour, and pleasure, by insisting on the extra initial expense that thoroughness of workmanship entails. Gardeners ' of England, take warning by me'; abhor cheapness, which means shoddiness and inadequacy; utterly eschew the saved sixpence, which means sooner or later an outpouring of pounds.

My critics have so alarmed me by describing my standards as impossibly high and discouraging, that I must deny their accusation incessantly. There is nothing in what I say to discourage small gardeners, poor gardeners, enthusiasts whose scale is limited. I only insist that they must prepare their ground thoroughly, and not spare the extra half-hour in building their garden, which will ensure through later years the prosperity of even difficult, capricious beauties. It is not lavish expenditure that I preach-it is thoroughness, thoroughness, thoroughness. 'Thoroughness, that cheapest and best of investments; thoroughness, the gardener's richest capital; thoroughness in preliminary preparation, his easy, perfect insurance against all the woes that afflict the little flock in his charge. Of course if you are making a bog-garden by the acre, preparations will come heavy and expensive; but in a little space, such as most of our gardens allow, all my sermons, even if carried out to the letter, will only mean a trifle of extra care at starting, an hour or so of added labour, another six inches of soil removed-a few small details looked to in the building, which, at the time, are as trifling and cheap as they may seem unimportant-but which, in the course of years, will be found 
to make all the difference between a garden that is a pleasure alike to the owner and to the plants that live in it and a garden which is nothing but a perennial anxiety and expense. For, if you build well at the start, your money will come flowing back to you, multiplied, through a thousand channels. Spend a little more-ever so little more at the beginning, and you will be spending less and less, making more and more, as the seasons go by. Put a rare, valuable plant in ill-prepared, faulty ground; it dies or dwindles; plant it well, in well-planned territory, and it grows ever stronger and stouter from year to year, yielding you younglings, and affording you perpetual pleasure. In renewal-money, saddest of expenses, proper initial care will save you fortunes; for, with proper preparation of your ground, you will rarely need to fill up vacancies left by deplorable demises among your treasures.

Let my ideal bog-garden flow down converging slopes, and fill a broad hollow. Let its sparse rocks be porous and water-worn-either of light powdery tuff, or of the gnarled, fretted mountain-limestone. Let its aspect have a rich peace, untroubled by ambitious violent features, pinnacles, bridges, uneasy, fussy adornments. Through the middle, perhaps, among tangled thickets of Iris, a stream may meander; but, for the most part, I incline to the opinion that in a small place water had better be a haunting pervasive influence than an actual visible force. In my own gardens, flowing water serves its turn; but as a rule, it is difficult to look after, to keep clear of weeds and leaves, to hold in its course. Nor is it of any effect unless the stream be a big one. And in any case water, running or staying, is an uncommonly hard and expensive servant to control. Therefore, for general advice, I should say, let there be abundant moisture, yet none to see. But, of course, if space and water be at your disposal-space and such unhusbanded fountains as bless our Northern 
Land, the banks of your bog may, and should, slope gently up to stark mountainous rock-work above, whence brawling cascades may come splashing down over Caltha and Maiden-Hair fern, loitering in pools and under still dark caverns, widening into lagoons that mirror beds of Primula rosea and azure Myosotis. But this is merely a beautiful vision.

As for the bog itself; if your sub-soil give sharp, free drainage, if your site be a favourable slope, all your need will be to prepare rich ground, and then provide moisture to pervade it. Frequently, though, on heavy soils, it is necessary to do more. In fact, from my own experience, I think that it is always better if one can do more; namely, for a small bog, to take out all the soil to three or four feet, to fill the space with a sort of concrete tank, the concrete to be about four inches thick; then to lay six inches of rough drainage-rubble at the bottom; then at the floor of the concrete, at its lowest point, to knock one or two drainage holes, to let the filtered moisture run away; and finally to fill up with a very rich mixture -richer and heavier than the soil of the rock-garden itself-made of old manure, silver sand, peat, leaf-mould, and good loam, with a generous intermixture of stone fragments.

But the garden thus made will be, of course, only the choice nursery of your rarest, loveliest little things. It is in no way necessary to take such elaborate precautions to grow Iris sibirica, Spireas, and the larger, commoner glories of the bog-garden-which, indeed, require nothing more than juicy, retentive soil, and a certain amount of moisture. But, if one is a true enthusiast, it is very pleasant, at the bottom, say, of a slope aglow with great Lilies, Irids, Orchids, to have a space where the tiny jewels of Alpine loogs may be safe and at peace-where Gentiana bavarica, Primula involucrata, and half a hundred 
other such small delights may have their paradise. And, for these, it is best to make the elaborate excavation and concrete basin that I have described-not as an absolute necessity, but as a safeguard and preliminary precaution, which will make them a great deal safer and happier than they are otherwise liable to be-besides securing to them a suitable, reserved territory of their own, where their special convenience is consulted, and from which all the profane crowd of larger plants may be held in banishment.

And now I will give free rein to my ideal, and will conceive myself lord of a vast bog-garden, sloping richly away from a high crest of copse and rock to a choice flat space for delicacies far below. And my bank is now full-fed with fat soil, and its river flows down from the upper corner, winding through the valley, but touching each bank, even to the crest, with the benign influence of its moisture. For, where water flows, thence water always climbs, and the banks on either side a stream are always so far tinged with damp that they can never know drought, and therefore may fairly be included in the bog-garden, though their soil, to the touch, is merely fresh and cool, even in the driest summer heats. So into my happy valley parched Thirst can never enter. And now, to take first my choice of big things for the banks, what shall I begin to plant?

And at once comes up at my call the Queen-race of the bog-garden. For, though many and diverse are the dwellings of the Lilies-though Heldreichi and chalcedonicum blaze on the hills of Greece, though tenuifolium takes pleasure in hot, dry, dusty soil, yet, as a race, the Lilies are plants of the upper reaches of the bog, delighting in very rich, well-drained slopes, kept always cool by the influence of water at their feet. Then let the high places of my bank be filled with gorgeous auratum, Martagon, pom- 
ponium, monadelphum, szovitzianum, and giganteum. All these are woodland Lilies, revelling in rich, decayed soil and the shelter of undergrowth. All alike detest drought, and are glad to have water haunting their neighbourhood. No one can fail to mark this who has seen auratum, hunted and outlawed, with a price on its poor head, wagging great blooms among the cliffy copses of Kamakura, or the Turk's Cap peering from the gloom of Pinus montana on the highest tree-limit of the Oberland.

To me, personally, Martagon has never made any strong appeal, the colour of its pinkish blooms being sickly and weak; nor can I see much value in the new highpriced hybrids-Mar-han and Dal-Hansoni-which seem to me to have all the ugliness of Martagon and Hansoni, with the beauty of neither, aggravated by the combination. As for the Burbanki-crosses, these are too confused and suspect to be spoken of yet: some of them are obvious pardalinum.

But the snow-white form of Martagon is very notable even among Lilies. It is a rare and expensive plant, which is supposed rather hard to grow. My stock, however, came from an old cottage garden near Ingleborough, where it makes stout thickets; and though for some years I did ill with it, planted in a hot dry place, it is now luxuriant in cool rich soil, among ferns, at the top of a big slope that falls towards the bog in the Old Garden.

The other valuable Turk's Cap is Martagon dalmaticum, whose stalwart spikes are clothed with turbans of a glossy maroon so intense as to verge towards black. (Cataniae is similar, though less profound in tone.) This is commoner than the white Martagon, and is a perfectly sound grower in fair treatment, though all the Martagons require some years to get fully established and show their true character. Indeed this must be said of all Lilies, except of those that save one trouble in the matter by 
invariably dying after the first year. As for Martagon, though, it is so robust a species that it might well be established in our woods-and indeed has so established itself in several counties of England.

From its very first introduction Lilium auratum, leader of the Archeleirions, struck the British Public between the eyes, and became the type of splendour among Lilies. It is indeed a noble and magnificent plant, though, for my own part, I do not think it surpasses Krameri and Chloraster, sovereigns of the Euleirion group. But, of the tall Lilies, it is the finest garden sort. I have not yet indeed mentioned Krameri and longiflorum for my bank. My reason is that, do what you may with Krameri-provide it with well-rotted manure, and silver sand, and so forth-you will rarely see its huge rosy trumpets more than once, and you may think yourself lucky if you see them at all. Longiflorum, again, Browni, Chloraster, splendid, snowy, creamy trumpets, are not always to be really trusted as perennials, and I am only admitting to my bank Lilies that with precaution you can make and keep as soundly perennial as any Spiraea. Nepalense and neilgherrense are of more than doubtful hardiness; the new, beautiful, fine-leaved sutchuenense is not yet proved; sulphureum and Lowi are of no hardiness at all. Wallichianum and washingtonianum, stalwart and lovely, are difficult and capricious ; Parryi, the joy of Californian upland bogs, with canarycoloured trumpets, is a perfect fiend, at once a miff and a mimp; the rare Himâlyan polyphyllum, a glorified, pearly Martagon, is now, I think, unprocurable, as well as very difficult; as for Alexandrae, I have already recorded my opinion of that delicate hybrid.

So now we return to auratum. This Lily is the type of the copse Lilies, and in auratum we may notice the rule that applies to its whole cousinhood; all these Lilies love to 
send up their young growths through light scrub of bush or fern. When the stalk is mature, its first eighteen inches or so will be found bare of leaves; and, to such a height, these Lilies like to be shrouded in vegetation, which secures their young shoots from drought, storm, and frost. Even where the naked stem is not found as an indication, almost all Lilies enjoy a light covert, and dislike a parching isolation. The sun-loving speciesHeldreichi, tenuifolium, philippinense, concolor, medeoloeides, avenaceum, callosum, chalcedonicum, candidum, and testaceum-are more or less exceptional, of course, even if one can ever make a rule for candidum and testaceum (which one never can, as candidum sometimes seems to revel in shade); but, in practice, you can rarely do wrong by planting Lilies among Azaleas, Rhododendrons, Daphnes, and big ferns. Auratum, again, sets the fashion in the matter of food. Auratum has not the perverted grossness of giganteum, for whom no garbage is too disgusting ; but auratum is still a rank, hearty feeder, and you cannot possibly give it too rich and solid nourishment. The more manure it has the more violently will it grow from year to year, and the more years will it magnificently endure. Naturally the manure must not be too new or crude; but it cannot easily be too rich. And this rule governs almost all Lilies, especially all the forms of speciosum, which, however beautiful, have no place on my bank, because they bloom so late that the frosts begin, as a general thing, before their buds unfold.

The twin Lilies, long confused, monadelphum and szovitzianum, are not, I fancy, quite so greedy. They are very splendid people, far too seldom grown, very stalwart and perennial, when once established in good light loam, in the companionship of trees or bushes. In style they are tall and leafy, with abundance of brilliant, big yellow flowers, like very large canary-coloured Marta- 
gons. They bloom early, too, before the other great Lilies are showing bud. The remaining yellow Turk's Caps are the true pomponium, a very vigorous grower of medium stature, which has the rare demerit of a most hateful stench; and Hansoni, a yellow counterpart of Martagon itself, with which, though it is held an easy species, I have seldom done much good. The enthusiast, of course, will grow the rarer species, alike of the Cup-shaped and the Turk's Cap sections - maritimum, concolor, and dainty little starry Coridion. But these, difficult and evanescent, need not trouble the general gardener; and as for the Big Cups, tall Batemanniae and thunbergianum, dwarf alutaceum, and elegans in a dozen forms, these are pretty and robust, but fitted for the ordinary border. Of the other Turk's Caps, the most valuable is chalcedonicum, with its better, black-stemmed variety, excelsum, with flowers of dazzling sealing-wax scarlet that appear in August and September. But this loves warm, dryish places in the border, or among light grass.

Of 'fancy' Lilies there is roseum, like a dull pink Asphodel, and a blue-flowered species-a true lilium, and truly blue, though only of a dull slaty shade, which has recently been discovered in Korea. But of these the first is rarely grown, and the second has never been introduced. I shall not easily forget how I scoured a high Korean down for it in early March. The short grass was still sere and wintry; here and there the steep slopes were dotted with stunted bushes of Pinus koraiensis. Beyond, clear blue against the sky, rose sharp sterile peaks, and very far away below, to the utmost range of the eye, extended, map-like, the ridged, gravelly desolation of Korea. And on that Alpine pass the earliest sign of life was a Lily pushing its first soft shoot of green from the bulb. In the hope that it might prove the blue 


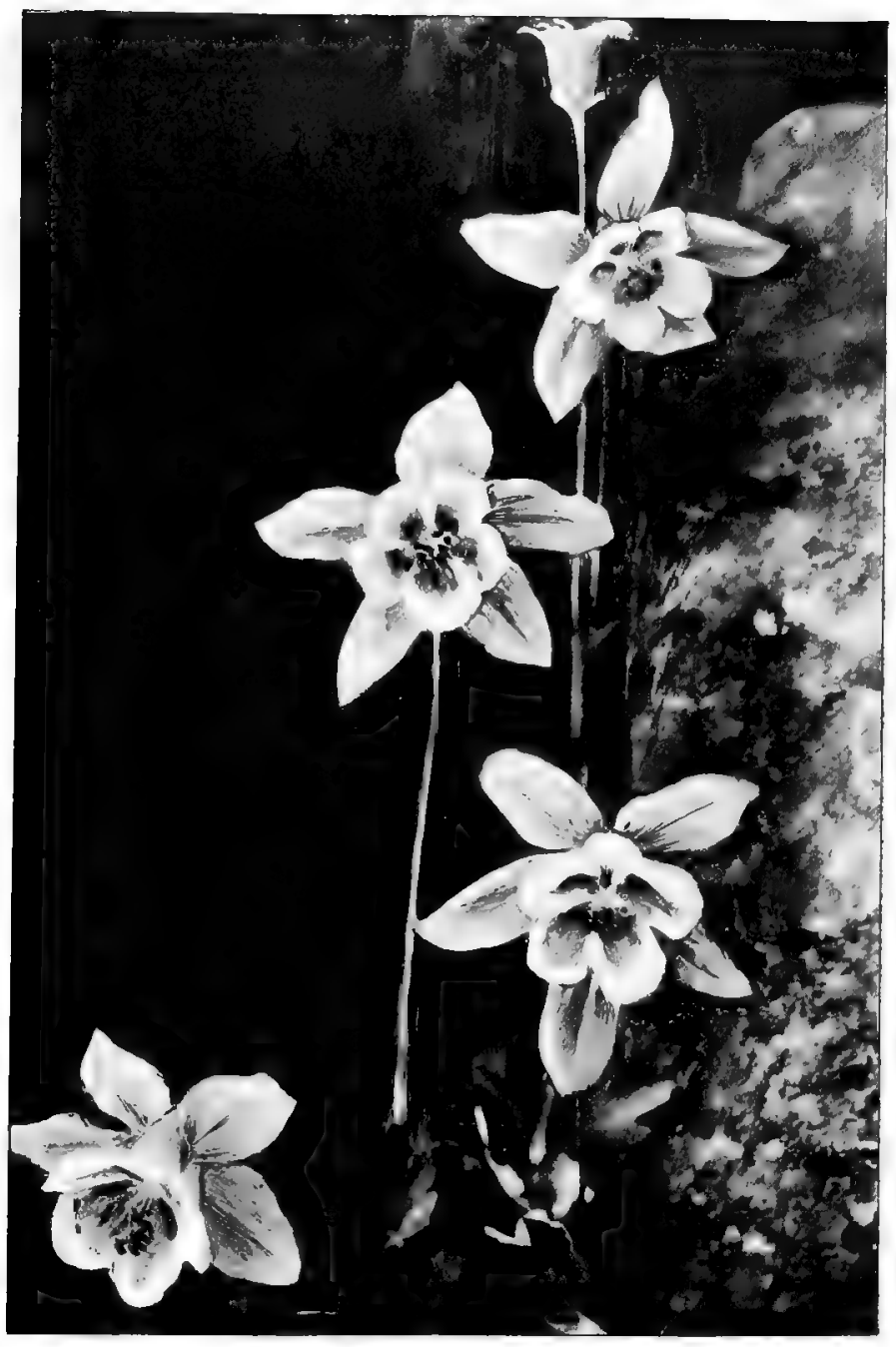

AQUilegia glandulosa. 
- 
novelty, I collected that bulb with laborious care, and carried it home to Japan, through all the changes and chances of mortal life, which involved a visit to the Great Wall of China and a fortnight of dust-storms and pneumonia in a hospital of French nuns at Peking. And for my reward that Lily throve and shot up to its full height like any heroine of a novel. But alas! when the gracious blossom opened, it was only Lilium medeoloeides, which, like avenaceum, is a smaller, frailer version of its compatriot, graceful, glowing-flowered callosum.

Auratum, nowadays, has many forms, and the first thing to notice is that auratum platyphyllum has absolutely destroyed auratum for gardening purposes. Platyphyllum is twice as large as auratum, twice as vigorous, twice as perennial, twice as easy to grow, and twice as brilliant. Indeed, I might have said thrice or four times without overshooting the mark, I think. Platyphyllum is magnificent; no one must ever think of buying the type auratum nowadays. Then there is the beautiful virginale, without spots, but a trifle delicate and capricious; and mubro-vittatum, with notable central stripe of crimson down each segment. And, finally, there is a new form just dawning over the Eastern horizon, in which I am this year indulging, despite its terrifying price. This is described as rubro-vittatum as far as brilliancy of colouring and crimson stripe are concerned, but as being pure platyphyllum in every other respect-in strength, in stature, in enormous size of blossom, in unpretentious readiness to thrive and persist.

As for Lilium giganteum, this unnatural-looking Lily comes triumphantly in to some high, copsy corner above the bog, a corner, if possible, sheltered from sun and wind. Glehni, cordifolium, and giganteum make up a small, strange group of Cardiocrinums, utterly unlike all the other lily-classes-Archeleirion, Euleirion, Isoleirion, 
Martagon-which haunts the dense gloom of pine-forests all over far Eastern Asia, from the wooded uplands of China to Saghalin and the dank darkness of the jungle in Hokkaido. The stolid, cone-like, scaleless bulbs send out many whip-thong roots that are gluttonous for food. Up come broad heart-shaped leaves, iridescent, glossy-green. Then, after years, a spike, tallest in giganteum, which reaches to twelve or fifteen feet, carrying ten to twenty long, narrow, white trumpets, very fragrant, white within, and purplish white on the exterior. The plant matures abundant seed, throws many offsets, and dies after flowering. Giganteum is the only one that need be grown, the others being smaller, inferior editions. This Lily is grateful for shade, moisture, and shelter, towering magnificently in sheltered, cool corners of the woodland, among ferns, but not requiring the copse-protection that the naked-stemmed lilies of the Archeleirion section prefer. Indeed, the big heart-shaped leaves of giganteum admit of no such overshadowing. The only other note to offer on this Lily is that it has the most hoggish appetite of any plant I know. If you want a first-rate colony of it on the crest of your bank above the bog, you will do well to excavate a pit and fill it with the contents of half a dozen swill-troughs and hog-pens; then stamp down rich light soil, and plant the lily-bulbs in it. It is perfectly robust and hardy, too, though it sometimes suffers from cold rains or melting frosts lodging in the goblet of the glittering leaves as they first unfold from the bulb.

Passing over now, as a rock-plant, my own especial favourite, delicious rubellum, we come to the lower slopes of my bank, and the great lilies that are definitely and frankly bog-plants, clamouring for incessant and abundant moisture. Lilium pardalinum is a tall, rampant grower, perennially vigorous, to whom no treatment 
comes amiss. It will even thrive among potatoes. But it especially loves the cool, rich damps of the bog-gardena high leafy plant, whose one fault, in the typical form, is that of sending up too many blind and flowerless shoots. The flowers, however, if rare, are magnificentbig, reflexed, spotted like the pard, on a ground of orange, vermilion, and scarlet. In the other forms, too, of this splendid Californian, the tendency to sparse-flowering is corrected, and Bourgaei, Johnstoni, californicum are all varieties of the Panther-Lily which exceed the type, if not in size, at all events in profuseness and brilliance. And all these Lilies, once inserted in the bog, continue thriving and increasing mightily from year to year, as if they were the worst of weeds. Lilium superbum is another North American, whose essential beauty is his tall, swaying grace. He grows to ten feet or more when fairly established in the bog, and carries a loose, airy sheaf of medium-sized flowers, more or less reflexed, and of the usual fiery colour.

The Tiger Lily needs no description or advertisement. This glory of autumn unfolds too late with me to give any perfect pleasure, for how miserable and tantalising to see fat, rosy buds all gnarled and browned with frost! And Lilium tigrinum is not a bog plant. However, on the heights of the bank the Tiger Lily with its trebled forms, Fortunei and giganteum (but not its horrible double variety), may well be placed in huge, bold clumps, well above superbum, pardalinum, and the others that love the damper levels. Among these perhaps my own especial joy and pride is the rare and rather ill-reputed Grayi, which I now have firmly and unquestionably established in a sopping corner of the bog, where it yearly doubles the number of its spikes. Grayi is a little, slender lily, carrying a loose spire of rather small bell-shaped flowers, pendulous, of orange and crimson. Like all the Panther- 
group, it flowers in August and September, with pardalinum itself, superbum, and Roezlii, making the bog into a glory of sunset colour.

Roeslii is another rare and difficult Lily, taller than Grayi, and much more brilliant, but still a mediumsized species. With this, again, I have had complete success in a corner of the bog above Grayi and not so wet -to balance against my modified failures-hitherto, say I, for hope is the hardiest perennial of all-with Hansoni, and with glorious Henryi, the new Lily from Ichang, which is unworthily called the 'orange speciosim.' Henryi is three times the height of speciosum and infinitely more beautiful, with daintily-balanced big flowers of a soft, dreamy apricot-colour. And this new-comer is reported by all growers to be of the cheerfullest temper and the most exhilarating constitution under almost any treatment. However, fate or folly has been adverse to me. I have grown Henryi, and flowered Henryi, in many soils and aspects. But $I$ have never yet turned it into a weed, never succeeded in growing it into a wild copse of yearly thickening stems. This, though, is by the way, for Henryi is in no way a bog-plant, but will come in among bushes, high up on that precious bank of mine where failure is not known, since it never yet was seen on earth.

But I must now lay earnest praise and a tribute of gratitude before these Lilies, bog-species or no. They have the longest flowering season of all bulbous races. The ball opens with rubellum in May; then hurry on candidum, alutaceum, monadelphum. Testaceum follows monadelphum; then, as summer ripens, the Euleirions take up the tale with longiflorum, and the Archeleirions break abruptly into the glory of auratum. But before auratum has come, Brozeni and Chloraster are in bloom; then Krameri, if you are lucky-and all this while, too, the undistinguished blaze of the common 
orange lilies of every cottage garden continues, and in the glow the varieties of Martagon and earlyblooming Hansoni pass almost unnoticed. August witnesses the triumph of auratum; but this is soon crowded out by the onslaught of all the Panther-group, Pardalinum at its head, Grayi, Roezlii, Henryi, superbum, Humboldtii, and canadense pressing close. And, in my garden, while these flames of red-gold fire are blazing, they are half-quenched by the soft violet of the common wild Vicia Cracca, which has established itself as a weed in the bog-garden, and yearly threatens to strangle in its chains of purple the swathed, labouring fires of Lilium Roeslii and Lilium pardalinum. Then, after these, while auratum and longiflorum still gloriously linger, speciosum and tigrinum are preparing their buds. With the last lapsing petals of auratum break the first buds of tigrinum, and, in a little, if frosts hold off, the blooms of all the Speciosums open, and carry the triumph of the Lilies far on into the dank, decaying days of autumn. Even in the sere sad hours of late summer, amid the withered herbage of the rock-garden, you hail the terrifying scarlet Turk's Caps of Lilium chalcedonicum, repeating in colour, though with more than doubled size, the brief June splendour of tiny little fairy-like tenuifolium, blossoming in the dry, warm, sandy corner of the rockwork. And, last of all, while Christmas approaches in its black horror of death and decay, the towering six-foot spikes of Lilium callosum make their annual silly attempt to flower, pushing more and more strongly every year in ordinary soil, but never, apparently, able to complete their lush growth and come to blossom before the depths of winter. If only it had not this foolish habit, callosum would be a very valuable Lily, magnificently healthy and persistent, tall, long-leaved, graceful, with profusion of reflexing orange flowers. Perhaps in time this new-comer 
from Japan will settle into ordinary garden routine and adapt itself to our conditions.

Humboldtii and canadense are two more bog-lilies in the cousinship of pardalinum, but very much smaller and more slender. Canadense grows slenderly to about three feet or so, and then, on long pedicels, carries two, or perhaps three bell-shaped flowers in orange and crimson, near those of Grayi in shape, but rather larger. Humboldtii is more beautiful again; and, in its high-sounding variety bloomerianum magnificum, more beautiful than itself. This form of Humboldtii is the only one to grow. It thrives well, and sends up loose, well-furnished spikes of flowers, which are large, spotted, very cleanly, and brightly coloured in yellow and red, and strike a compromise between the bell-shape of Grayi and the Turk's Cap of pardalinum, by assuming the form of a large star, just reflexing at the tips. Maritimum, cup-shaped and crimson, is a rare, dainty North American which $I$ have never grown, and with Humboldtii closes my list of Lilies for the big ideal bog and bank.

Of Parryi I dare not speak; this is a Californian, usually called a bog-plant, slender, leafy, striking, in shape of bloom a medium between pardalinum and the Isoleirions-that is to say, in the form of a rather shallow trumpet, soft, rich yellow, sparsely spotted and very sweet. But Parryi is a problem almost insoluble. Captain Reid grows it like a weed at Yalding, I understand, but no one else, not even the most experienced, has any but an evil tale of it. Clearly bog-treatment by itself is not enough. I incline to the belief myself that it hates bog treatment, except, perhaps, for short periods in the year. However, I will say no more. My bank contains only such Lilies as are really and honestly healthy, goodnatured, and robust, capable of adding willingly to a garden's permanent glory; to the capricious, delicate, 
uncertain species I say a glad good-bye-or, rather, in these pages give them no place nor greeting. Let others specialise on them; I have given you only sound, vigorous Lilies. And the list, you see, is not a short one. Good luck to all. 


\section{CHAPTER IX \\ The Breater Boy=界lantg}

OF the shrub-Spiraeas I will not speak here-at least not of the big species such as ariaefolia. And Aruncus has been treated of 'in another place.' But if you want gigantic, tropical vegetation for the rich rough uplands and outskirts of your bog, you cannot do better than turn to the gorgeous, herbaceous Spiraeas. Of all these I would say that if your space will possibly allow, they will look better in wide tracts and colonies than as isolated specimens. In point of growth, luxuriant and rich as they are, they do not run at the root or make themselves a nuisance, and can therefore be admitted without scruple even to the smallest territories. But nothing can beat the effect of a broad sweep of palmata or gigantea, and, where possible, they should certainly be planted with a lavish hand. I conceive of a broad, shallow dip between two wooded hills, through which, in lake and marsh, shall meander a little stream, while above, far up on either side, rise sheltering forests. Here, in the open space of this glen shall be towering masses of the finer bamboos, clumps of Thatictrum aquilegifolium, waving copses of the big Lilies-auratum, pardalinum, tigrinum, giganteum. And here, too, amid belts of the Siberian Iris-there will not be blazing sun-heat enough for Iris Kaempferi in this wood-garden of mine-there shall be jungles of the rosy herbaceous Spiraeas. For these, one 
and all, are of a temper indomitably robust, able to look after themselves anywhere, capable of coping with any native weed, no less free and sturdy than their sister the common Meadow-sweet. All they ask is a rich, cool soil, like that of a damp meadow. They don't clamour for extra moisture or bog-treatment, but revel in any such position as the banks of a ditch. At the same time my visionary wood-garden must be very careful how it admits the Spiraeas into the neighbourhood of the great Lilies. For the fiery orange and scarlet of the Tiger and the Panther simply yell and squall, like furious Kilkenny cats, against the chalky pinks of the Spiraeas. This colour, radiant and clean, is the one weakness of the tall Meadow-sweets, inasmuch as it is very reluctant to mix on equal terms with any other.

First and foremost of the big Spiraeas comes gigantea. This is the ordinary Meadow-sweet multiplied by three, an enormous tropical thing, waving wide plumes of creamy-white at the top of eight-foot stems, clothed in broad palmate leaves. In the pink form the flowers are are of a pale, ineffective rose, but the type is incomparably better, in richness and splendour of effect. Spiraea gigantea, besides being as easy as all its kindred, has, like Aruncus, a hearty readiness to seed itself about the garden.

Next comes, for old friendship's sake, the common Meadow-sweet, gigantea's little sister, a native whom no one need ever be afraid to admit, as, however freely it grows, it never proves a stubborn usurper, nor makes itself difficult to deal with. Lovely Spiraea palmata is larger than ulmaria and smaller than gigantea, coming about half-way between them, though in leafage and habit it is nearer to gigantea. And its flower is far more brilliant than either, being a flat plume of soft, bright rose. However, palmata varies very much from 
seed, and out of a batch I raised a year or two ago I was horrified to find that half my cherished nurslings bore blossoms of a pallid, dirty pink, a hundred tones removed from the rich splendour of the normal palmata. As for the albino, it is beautiful of course, creamy and opulent. But there are many good white Spiraeas, and the white palmata is not as conspicuous among whites as the type is among the pinks.

If palmata approaches nearer to gigantea in habit, lobata (or venusta) approaches nearer to ulmaria. Venusta is a Meadow-sweet of frail and slender growth, lacking the weed-like robustness and luxuriance of its kindred. Not that it is in any way capricious or difficult; any cool soil will please it. But certainly it does not form masses, spread, seed, and increase like its relatives, always preserving a certain spindly, fragile look about its isolated stems. In flower, however, venusta dominates its race, and utterly eclipses all thought of rivalry. By the side of venusta the pinks of palmata and digitata become pale and dingy; for the foaming crown of venusta is of a violent dazzling carmine, richly brilliant and pure as the juice of red currants. I know no albino of venusta, nor desire to, the type being unsurpassable.

Spiraea japonica heads another group of herbaceous Spiraeas which are all as easy as the Meadow-sweets, and very valuable for smaller, choicer corners of the damp garden. These are dwarf in habit, and adapted for planting in isolated crowns and specimens, their plumed grace appearing to the best advantage so, at some commanding point in the garden's scheme. Japonica itself, the commonest of plants for forcing, is no less precious and beautiful for the open ground. It is imperturbably robust and hardy, requiring no attention from year to year. Each season reappear anew its lovely dark-green glossiness of fern-like foliage, and then the loose, 
delicate spires of white. Though perfectly vigorous and healthy, it is rather more impatient of sunshine than its kindred, and will do you better, and show you finer spikes, if you plant it where the blaze is not excessive.

The Astilbes have not even this faint want; they thrive anywhere in cool soil-herbaceous Spiraeas in all but name, prolific of the usual bending plumes of white or pink. I cannot enter upon the minute differentiation of Astilbe, Spiraea, and Aruncus; if the lover of the race remembers it altogether as Spiraea, he will be wise enough for all ordinary purposes. Astilbe rivularis, Spiraea astilboeides are both lovely, easy ornaments of bog or water-side; tall, airy, stately are the hybrid Astilbes, Nuée Rose and Silver Sheaf-whose names describe them-enlarged, glorified versions as they are of rivularis. Nuée Rose has a soft, appealing shade, but in the cousinhood of japonica by far the best pinks are given us by the two new varieties of japonica itself, which are called respectively Peach-blossom and Queen Alexandra-and of which the Queen is infinitely the better, as she should be,-_tall, rosy, perfectly graceful and noble. Both kinds, though, bear large profuse feathers of the loveliest, tenderest rose, superior to almost every other colour in the race. Nor must I leave out, for loyalty's sake, Japonica Mr. Gladstone, a magnified form of the type, carrying glorified spikes of pure white. As for Aruncus sylvester from Japan, this is a close cousin of Spiraea Aruncus, producing, on tall, loose stems, long sheaves of white or pale pink.

Astilbe Davidii is new enough and still rare enough for the glory of a separate paragraph. Its rarity, however, will not long continue, as it seeds so faithfully and generously. Further, it grows, thrives, increases like the most vigorous of its kind in any cool soil, in any exposure-a most notable, splendid introduction from the 
'hinterlands' of China. Each year its broad, glossy, ferny leaves form a wider spread; each year, above their flattened mass, the stiff straight stems shoot higher and higher, clothed, all along the last foot of their length, with innumerable crowded little flowers in a dense, close spike. I cannot make up my mind about their colour though. Do I love it or do I loathe it? For the colour is a furious magenta; but a magenta deified by some strange magic of violence or splendour - a deep, clamorous, imperial tone. The fact is that Astilbe Davidii may be adored without reserve, if only it be very carefully planted. It must not be within a mile of any yellow, any orange, any pure rose or scarlet; and, unfortunately, it blooms in the bog-garden, while the Panther Lily, Senecio clivorum, and the pink Meadow-sweets are all in their mid-day, dawn or decline of glory. It should, I think, be isolated as a leper, not even admitted to communion with the white flowers of blameless lives; plant it all by itself in a ferny hollow, with nothing but ferns and greenery around, in a spot where the sun's darts may pierce the woodland and kindle the full fire of its incandescent purple; then you will have reason to be perennially grateful to Astilbe Davidii. Of Astilbe grandis I can tell an unblemished tale, although the plant is too new for any but the sketchiest commendation. But it can certainly be said that Astilbe grandis is a plant of impeccable character, robust as a nettle, a doubled, gigantic version of Davidii, revelling equally riotously in the same conditions, and throwing up aloe-like, skyypointing pyramids of white bloom.

And here, before I take my leave of the Spiraeas, I must make room for the jewel of the race. This is not a bog-plant, but a tiny treasure that delights in some cool moist corner of the choice rock-work. But I am not sure about the botanical position-even about the botanical 
existence, of Spiraea digitata. For, horticulturally described, it is simply a minute dwarfed form of Spiraea palmata-a tiny brilliant version of a big brilliant original which does not, or should not, exceed three or four inches in height, although the spreading plume of its blossom is no less large and no less rosy than that which crowns the leafy three-foot stem of palmata itself. 'Should not,' say I, though, in my uncertainty. For digitata is suspiciously liable to variation, and though I have many plants that remain perfectly true, trusty and tiny from year to year, producing tinies too from seed, yet again $I$ have had Digitatas that waxed fat and kicked like Jeshurun, and swelled into ordinary stunted specimens of palmata. This leaves me doubtful whether digitata, permanent and perennial though its habit may generally be, is not perhaps a local, possibly an Alpine variety of palmata, which, in ninety-nine cases out of a hundred, remains distinct, but not in the hundredth that constitutes a true species. In any case digitata is one of the loveliest things on the rock-work, and delights one even further by bearing its wide rosy flower-heads all through summer and autumn, far on into the dark days of early winter, when there is nothing left but the mudflecked, slug-nibbled cups of Colchicum, repellent in their acrid and poisonous-looking magenta. Spiraea digitata, always remaining a dwarf, restricts itself permanently to a single crown, never runs about nor grows weedy, but illumines its select corner from year to year with its crest of rosy foam, and makes seed in just sufficient quantity to give you always a few babies, though never as many as you would like to have of so willing, persistent, and beautiful a fairy.

A little while ago I mentioned Senecio clivorum. To Senecio clivorum I now return. Senecios they are called by botanists, 'but liberal gardeners give a grosser name.' 
For these are the Groundsels, and a larger race of duller and more pernicious graceless weeds does not exist on the face of the globe. In every age, in every clime, by every race abhorred, the Groundsels, in their innumerable ugly avatars, possess the wide earth to the exclusion of the meek, its lawful heirs. Meekness is no virtue of the Groundsels; dowdy they may be, and most generally are; but where beauty occurs in the race, it appears with an ostentatious arrogance that betrays consciousness of its rarity. For there are beautiful Senecios, whose beauty admits of no question. I name four-pulcher, japonicus, clivorum, and Doronicum. It is true that japonicus is ashamed of its cousinship, scorns the hated name of Senecio, and lurks nowadays under the disguise of Erythrochaete japonica. But not even this barbarous blend of Greek and Latin can secure it from recognition. Senecio it is and will be, with big leaves, round in design, but deeply incised, and clusters of very large flowers of a radiant, intense golden-orange, carried on stems two or three feet high. Senecio japonicus is fine and brilliant for the large bog, loving any deep, cool, rich soil, and its one fault is a certain niggardliness in the matter of flowering.

But Senecio clivorum is the giant of the race, forming in three years from seed a mass, six feet across and as many high, of great rounded leaves on long stalks, and countless sturdy tall masts, adorned with many-flowered heads of enormous orange blossoms. Like japonicus, clivorum blooms through late summer and autumn, and is of prime value for some high, bold point in any wood or bog-garden whose extent is large enough to hold such a Titan; it is a ramping rooter, in deep rich soil, not parched or dusty; is perfectly robust and hardy; and never makes a weed of itself, but multiplies the number of its crowns until it forms a big, centralised clump after 
the manner of Spiraea Aruncus. As a water-side plant Senecio clivorum quite extinguishes its other big robust cousins, the Ligularias, fine dock-leaved things, with tall spires of uninteresting, stodgy yellow.

Senecio thianshanicus is another new introduction, also from Upper China. For this I have so far but little use. Its growth and leafage is that of a Wormwood, and its inflorescence cloudy and loose, made up of innumerable minute flowers, reminds me of a Golden-rod-a thing I hate-or else of a yellow Spiraea. Also it seems to run about and form a colony. Late summer and autumn sees these stout Groundsels in their prime, but when they are going to rest they are followed, in late October, November, and December, by the insolent, dreadful glory of Senecio pulcher. The beautiful Senecio hails from Mexico, a smallish plant by comparison with its giant kindred, growing to two feet or a little more, with spatulate basal leaves of glaucous blue-grey, leathery and smooth, and then, on a bare stem, three or four large flowers of a blazing magenta-purple, eyed with gold. In dull dead days, the fire of this is wonderful in rare glimpses of the pale sunlight, and the plant has thus an artificial value besides that of its own intrinsic splendour. But this unexpectedly hardy exotic is not, after all, of perfectly unquestioned hardiness. And it is by no means a plant for the bog. On the contrary, it detests superfluous moisture, and must have, to do itself justice and be permanent, a warm, sheltered, sunny corner well up on the rock-work, in very deep rich soil, warm and light, through which its vast vermicelli roots may go roaming untroubled by corroding damps.

Let us now deal compendiously with the other Groundsels, since among them we are landed, leaping away for a moment from the low-lying territory of the bog. And a far leap it is, too; away through the clear air to the 
last highest limit of the Alpine pastures, and the first stretches of stone that lead upwards to the moraines. For the remaining Groundsels, at least those of value for our gardens, are genuine Alpines. First of all in order of merit, facile princeps in my heart, and certainly the best for gardening purposes, is Senecio Doronicum. This you do not see until Arnica has given up the climb in despair, and remains below you on the upper slopes. As you go higher and higher, over the fine turf of Alpine clover and Azalea procumbens, you come at last upon Senecio Doronicum. In growth, shape, and colour of leaf this is not unlike pulcher, though rather smaller than pulcher at its finest. But the blue-grey leaves, with their snowy reverse, the grey stems, the grey calyces are clothed with a fine soft tomentum, which gives the whole plant a delicate effect of silver. The flower-stalks carry only one or two blooms, but these are much larger than those of pulcher, and of a fierce, penetrating, deep orange, which, for profound intensity of beauty, I can match with no other yellow, and which contrasts, too, most gorgeously with the moony argent of the leaves. This glowing treasure blooms in midsummer, and is far too seldom seen in cultivation, being as easy and indestructible as its cousin the common Groundsel. Silver tomentum also clothes our own very rare native, Senecio spatulaefolius, from Mickle Fell, as well as Senecio campestris, of which it is a form. But these, with ordinary yellow flowers, are so much less lovely than Doronicum that the silver tomentum in their case may be called white wool. Senecio adonidifolius is a coarse little weed, with ferny foliage and wide heads of small golden flowers; beautiful little aurantiacus is much smaller, with foliage as fine as a Camomile, and fewer, larger flowers of a dark, flaming orange. This, however, is a true Alpine, for the choicest part of the rock-garden, in granitic soil, and has 
not the free habit, and certainly not the rare startling beauty that distinguishes Senecio Doronicum.

No; having climbed high in a moment on to the beloved Alps of my heart's eternal longing, I will not come lumbering down again immediately to the levels of my bog-garden five or six thousand feet below in the stuffy, wooded valley. It is too far to go for only one tantalising minute; now that I am here I will stay a while and drink deep breaths of the mountains, and wander round among the lesser cousins of the Groundsels. Every one knows the big leafy yellow Leopard's Banes of every cottage garden, carrying abundant coarse Dandelion flowers in early spring, on tall stems of two or three feet. These one may grow in rough worthless corners, and both plantagineum and pardalianches are so vigorous that they have established themselves as wildlings in several English woods. Orphanidesi I reared from seed, and had high hopes of, because only one seed ever germinated. However that, in the changes and chances of the pottingshed, vanished mysteriously, and was no more seen. So I have little to say of Doronicum. But the high Alps give us some cousins of the Doronicums that are almost their twins. The Aronicums, of which glaciale and scorpioeides are to my eyes barely distinguishable, only come into view when you are leaving even Senecio Doronicum behind, and are well up on the desolate territory of the moraines. Here the broad, ephemeral leaves of the Aronicums begin to peer at you from stony slopes and the shadow of dank wet rocks. They look far too flopping, thin-textured and brilliant in their shallow green to be growing here in this desolation, amid these rigorous stern conditions, hardly a hundred feet from Eritrichium nanum, and within bowing distance of the glacial Ranunculus. Yet here these plebeian-looking creatures flourish, and here they send up occasionally, on short leafy stems, 
their large Leopard's Bane flowers of a clear, rather shrill yellow. But the flowers, though enormous, are weak in substance, undistinguished in appearance, and uninteresting in colour; I cannot greatly love them, though the memory of them has lured me so high upon the hills, and though they are robust, unexacting and persistent in any sort of cultivation, however brutal. Far better, a hundred times better, do I love the Amica, growing, as it does, a thousand feet lower on the Alps, among the varieties and hybrids of the big ugly Gentians, purpurea and lutea. And Arnica, when once you have gratified its morbid passion for peat, is as easy to grow in the rockwork as any daisy, though slugs or mice have a tenderness for its buds and shoots. Every year, on a copsy shoulder of my peat-bed, among the straggling boughs of Cistus laurifolius, come up my masses of Arnica, in greater and greater abundance, their sweet, acrid, heartening fragrance, when bruised, blending delightfully with the haunting violet-fragrance of the Cistus. Not that my Arnicas are in shade; far from it; sun and exposure they require; the Cistus merely throws frail tentacular branches here and there towards them. Arnica is, par excellence, the dear plant of promise; when, on the bare hillside, amid the brown herbage, you first begin to see its ragged great orange stars rising high above the groundhugging rosette of broad, pale soft leaves, pleated and silky, then you realise that only a few score feet of arduous climbing still separate you from the high stony lands where Androsace and glacier-Buttercup run riot. Once, too, I found a couple of Arnicas that carried blossoms of a very pale sulphur-yellow; but these, though I collected them and nursed them carefully, never did any good and, I think, have since passed away. It is here to be noted, by the way, that Arnica has immense voracious whipthong roots, which must be allowed ample pastur- 
age and roaming ground if the plant is to do well; though otherwise there is no sort of difficulty attending its cultivation. No less easy, but rather less brilliantly beautiful is the smaller, more numerous-flowered Arnica Chamissonis that I collected in the Rockies and have since found perfectly easy to grow, though not very conspicuously worthy of the trouble, by comparison with the outstanding charm of Arnica montana.

Now I no longer have any shadow of excuse, and must soar downward again to my bog, resisting manfully any peevish inclination to call it a slough. A quantity of isolated species now claim garden-room and notice. Already have I sung my song of gratitude and praise to Anemone rivularis, Thalictrum aquilegifolium, Ranunculus aconitifolius, and Gentiana asclepiadea. All these must be throned piously in the bog, though the pretty, cloudy white stars of the Buttercup do not deserve the choice place that must be given to the lovely Anemone and its contemporary Willow-Gentian, with the long arching wreaths of sapphire trumpets, lightening up the garden in late summer, and coping with the hot flame of the Panther Lilies and their kin. The Buttercup takes any amount of moisture, and is patient of a good deal of shade. The others are not exacting, but will do best with a little less of either. Campanula macrantha, too, the enlarged version of our own giant latifolia, is a magnificent plant for some rough copsy corner at the outskirt of the bog. It would be dangerous to admit this near select quarters, but it makes a fine figure at the back of the picture among ferns and lush foliage. Another rare native and north countryman there is that $I$ loved from my early days, and still love, though with tears and reluctance. The Melancholy Thistle stands apart among its kind-though this, as far as I can see, is no reason why it should be melancholy -in having no spines or thorns 
or unfriendlinesses of any kind. The toothed, pointed leaves are smooth, of a very dark grey, clothed with white tomentum on the reverse. The stems, almost bare, are tall and few-flowered, also grey with down. The big fluffy blossoms are of purplish rose, and dowered with a faint, intoxicating scent, which I earned a prophetic reputation for eccentricity by loving even in the remote days of my childhood. In one form of Carduus heterophyllus, too, the leaves are gashed and slashed into so handsome a pattern that they come to recall the convention of the Acanthus. Actuated, then, by admiration and old love, I introduced the Melancholy Thistle from the woods above the Lake to the bog in the Old Garden. Immediately, however, the drooping creature cheered up in the most dreadful and depressing way. It grew and it grew and it grew, it spread and it spread and it spread; ever since I have been waging vain war with the invader, spudding it up to-day in one place only to find it burgeoning anew from another to-morrow. My combat is with a Lernean Hydra; the plant runs underground, and makes two shoots, it seems to me, for each one that I cut off. But still I love the Melancholy Thistle, wicked, fascinating creature, which is not content with the iniquity of ramping insatiably underground, but must needs also fill the air, all summer through, with flying silver clouds of seed. Just such a wickedness characterises, too, as I have said, those other wicked applicants for admission to our gardens, Epilobium angustifolium and Epilobium hirsutum. Yet though their guilt is no worse than the Thistle's, I frankly detest the Epilobiums, and warn you all yet again and again, never to be seduced by their pleasant beauty into giving them so much as an inch. For, in that case, be assured that they will not only claim, but occupy, not one, but scores of ells; and by their monstrous fecundity 
will turn your wretched garden into an ell with an initial $\mathrm{H}$.

If you have unlimited space at your disposal, and high bold corners, you will not, of course, omit the Gunneras and the Pampas-Grass. Nothing is more magnificent than a big old clump of Pampas, drooping and weeping and luxuriating over a lake, from some lofty precipitous point of rock-work falling sheer towards the water. It is so I have it in my Old Garden, and for once, the actual makes a model for the ideal. The effect is splendid and marmoreal. The Gunneras do not waken my zeal to the same extent. 'They are immense-' 'à formes architecturales '-like gigantic Rhubarbs, swollen in a nightmare. Their hardiness hovers on the edge of doubt; they like a little sifted ash for protection in winter ; and, altogether, if I am to tell the truth, I myself admire the great cutleaved Rhubarb, Rheum palmatum, with its towering spires of crimson blossom, to the umbrella-like enormousness of the Gunnera-foliage, concealing their stodgy dull spikes of greenish-yellow flowers, like gigantic bottlecleaners. On the other hand, while Gunnera scabra and Gunnera manicata are so colossal as to have no place in any garden that cannot be measured by the mile, Gunnera magellanica is so minute as hardly to be visible to the naked eye, and certainly is no more covetable than the common Coltsfoot, though, possibly, less of a pest.

Of foliage plants for the lake-side, though, or the big bog, there is nothing to surpass the Rodgersias - the old podophylla, with wide, bristly, five-cleft leaves, bright and glossy, ranging from emerald green through every shade of red, bronze and purple. The plant runs freely and forms a fine sheet of shining leafage on a slope-as I saw it once clothing a whole hillside in the Hokkaido, though its flower spikes, just rising above the leaves on their twofeet stalwart stems, are not of any great decorative 
importance. Any cool moist soil, in peat or loam, will please the Rodgersia, and it does not enjoy exposure to torrid sunshine. The same remarks apply to the new pinnata, with dainty graceful spires of Spiraea-like bloom, either white or pink, and to the still newer and rarer tabularis.

I have no strong affection for the Megasea Saxifrages, such as ligulata and afghanica-leather-leaved, large things, with coarse flat heads of pink or white. But Saxifraga peltata reigns a queen by bog and lakeside, and I greatly wonder that I have not already paid it my heavy debt of gratitude. Saxifraga peltata hails from California, and yet is of the most imperturbable hardiness and vigour. Its gnarled, knotted root-stock goes crawling about over the bare rock at the water's edge, suggesting the tentacles of the octopus, combined with the wrinkly blackness of an elephant's trunk. From the round green knob in which each wandering tentacle ends, there rises in early spring, on a tall bristly pink stalk about three feet high or so, a shower, like a spreading rocket, of innumerable rosy stars. Then the flower dies, and up break the splendid leaves in abundance-large, palmate, brilliant, having something of the Nelumbium's beautiful cupped design, though glossygreen, hispid and incised. They are carried high, sometimes to the height of a man, and in a few seasons one plant will form a mass in which cowering Monmouth might have found better covert than among his cabbages -or was it barley? Then, in autumn, each broad umbrella fades into russet, orange, scarlet, violet; and so droops and pales at the approach of winter. So vigorous and so beautiful is this Saxifrage that one's only peril lies in using too much of it. It should certainly be established everywhere, as it will look after itself among the roughest weeds of the woodland and the water-side. I 


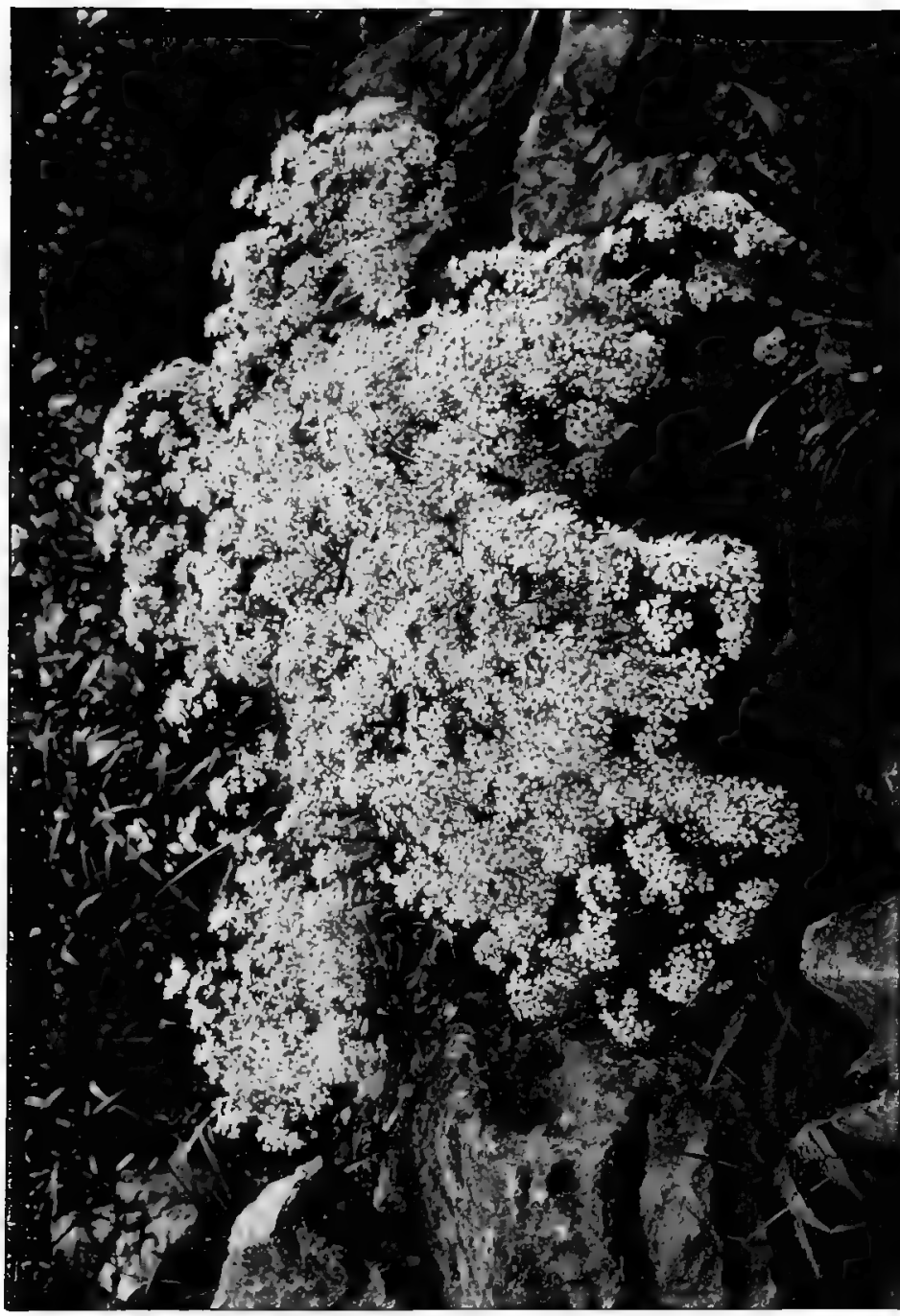

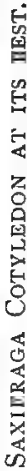



have it thriving in the wild-wood garden now, and making a mock of brambles and long grasses. As for propagation, you have only to cut off a few inches of black tentacle in early spring, with a green bulge at the end, and plant it firmly in good soil. Soon the lopped member will shoot and start creeping. Once started, it will ramp on and on, over naked rock or concrete, seeming to need no more nourishment than it gets from its original starting-point and the moisture all around.

Who is there that will not grow Cypripedium Reginae? I need say no more. I have already chanted the psalm of the Queen-Slipper. Give it light rich peaty loam, perfect drainage, much enrichment of old leaf-mould, a fair degree of moisture, and the shelter of neighbours. Then you will do well and permanently with the Cypripedium. Especially may one suggest the Osmundas regalis, and cinnamomea,-or Struthiopteris, - as companions for the Queen-Slipper, which never looks lovelier than when peering from amid the rich filminess of ferns. The Bamboos might serve, you would think, but not one of them may ever be trusted within two hundred yards of so choice and forward a spot as you would naturally choose for the Cypripedium. Eulatia, again, tall and elegant, is only fitted for such high places as you might otherwise grace with the Pampas. A specially dainty occupant of the large bog is the seldom-seen Poterium canadense. Our own Poor Man's Pepper-box, Poterium sanguisorba, is too dull in flower, despite its exquisite foliage, to find a corner, but canadense, having the same choice design of leafage, multiplies the whole scheme by three, and is a fairy giant of a plant, sending up in very late summer and all through the autumn, six-foot stems, terminated by long fluffy spikes of white, similar to the Cimicifugas, in a way, but far more attractive. This will grow in any rough place, and needs no trouble at all. 
The Cimicifugas never attract me very much; their glossy, elder-like foliage is very handsome, and effective too are the long bottle-brush spikes of white that they send up to the height of five feet or more-some in early summer, and others at intervals on into late autumn. Davurica, I fancy, is the handsomest, and all thrive with the most unexacting ease in any cool soil. But they have something a little coarse and rank about them, to my taste-perhaps a hinted warning of the poison that lurks in all their being. It is fortunate that poison-plants seldom if ever fail to offer some such indication of their nature to the sensitive observer. Who would take Atropa, Hyoscyamus, or fatal Hellebore, for ordinary benign, innocent creatures; or fail to feel an intuition of evil about Monkshood, Foxglove, and Daphne mezereon? And the Cimicifugas, like their rare native cousin, Actaea spicata, are too unmistakably ominous in appearance to have the full attraction of their beauty.

The Loosestrife, on the other hand, is plain but respectable, to set against the bad prettiness of the Baneberries. I call Lythrum salicaria plain, perhaps cruelly and without justice, but its profuse spikes of flowers have a lacerating crudity of magenta that destroys everything else within a radius of a hundred yards, kills all the joy of one's eye, and quite disqualifies the Loosestrife, handsome and blameless as it is, for any place in the careful and selected garden. I had it once, by accident, next to a flaming orange mass of Montbretia Pottsii. Shrieks fail utterly to paint the horror of that jangle, "which fiddlestrings is weakness to expredge my nerves' when I recall it. The other, true Loosestrifes - Lysimachia, not Lythrum -are useful, tall coarse things for the distance, for remote places with which we do not more closely concern ourselves.

Spigelia marilandica is an American from southerly 
parts, who bulks large in many gardening books. The plant is not easy to grow, uncertain in temper, miffy in constitution, exacting as to climate, dependent on perfect drainage and abundant moisture. And when, after all these stumbling-blocks have been surmounted, and you at last succeed with the plant, as one year I had the privilege of doing, you see a weedy growth like a poor Gentiana asclepiadea, carrying very similar flowers, trumpet-shaped, reddish outside and yellow within-or the other way round; I cannot really remember. In any case I did not love it nor glory in it; and when it departed this life I did not replace it. Rhexia virginica is a compatriot, a tiny marsh shrub, loving wet sandy peat, and very gorgeous with its abundant large flowers of purplish crimson. I imagine them like those of Lagerstroemia indica on a small scale, clawed at the base. The truth is that $I$ have never seen mine in flower. The plant has not done well with me, and when, one year, my manager succeeded with a fine batch of imported clumps, I was not there to see, and by the time I returned the Rhexias had relapsed into their more normal state of moribund sulkiness. In sunnier climates, with perfect drainage, this will probably do better; Rhexia mariana is unquestionably half-hardy, hailing from more southerly parts than virginica.

A third American we have, of first-rate value for the bog, either big or choice, in Lychnis haageana. This comes readily from seed, grows willingly and freely, though never obstreperously, and is perfectly trustworthy and perennial. It loves the peaty bog, is tolerant of abundant damp, and looks after itself from year to year. It throws up rather weak, leafy stems to about two feet, and then freely produces round cart-wheel blossoms of an orange-scarlet more terrific than anything else in the garden-even Gerbera Jamesoni. It varies in colour, it is 
true, from seed, but all its shades are brilliant. Lychnis fulgens and Lychnis grandiflora, its aboriginal types, have never done anything much with me, nor has another marsh Lychnis which has been reported beautifulLychnis striata, also from Japan, which sounds like another form of the fulgens group. Probably these two wanted hotter summers than I could supply.

The May-Apples, hardly bog-plants, rejoice in a rocky nook within the influence of neighbouring damps, and look beautiful peering from a cliff in such elegant company as that of exquisite Adiantum pedatum, the hardy Maiden-hair from New Zealand, or of our own native Maiden-hair, of every greenhouse and all our Western coasts, if you are so fortunate as to establish it as a hardy perennial beneath some overhanging ledge of rock. The May-Apples are Himâlyans, valuable purveyors of medicine, apart from other plants in their strange growth. Plump and juicy comes up the leaf stalk, then divides into two branches, from each of which droops, and then expands, a broad smooth'glossy leaf, which in peltatum is roughly rounded, and in Emodi is of the same design but deeply divided into lobes. These leaves, of brilliant light green, are heavily veined and marbled with bronze and violet, nor do they ever lose this conspicuous beauty. Beneath the leaves, at the division of their pedicels, lurks coyly a small white flower like a tiny Paeony; in peltatum these are rather inconspicuous; in Emodi they are really very charming when once you have discovered them. Here, more or less, ends the tale of peltatum, but Emodi's flower gives place to an enormous seed-pod of the most brilliant vermilion, and a fine clump of this Podophyllum, carrying a dozen stems or more, each bowed beneath this weight of colour, is a splendid sight in early autumn, though the birds are greedy to rifle its beauties. Though peltatum also forms a pod, this enters into no sort of 
rivalry with that of Emodi. In both species the seed is abundant and fertile, ready of germination, and one can in no time raise a thriving stock of either. These MayApples require no treatment except to be planted in some good nook to themselves, in rich soil of either peat or loam, and there to be left quite undisturbed for many years. Of course, their broad, thin-textured leaves being a great beauty, and their juicy stems being brittle, they are grateful for a corner where they will not be flogged and victimised by harsh winds.

The place for Aster is elsewhere; but here $I$ must at last give due meed of honour to Aster pyrenaeus. Why do so few people seem to know, or to grow, this lovely and priceless Michaelmas Daisy? A tall, stalwart, bushy grower, very leafy, with lush bright green foliage, Aster pyrenaeus carries from midsummer on into autumn enormous, flattened pyramids of flowers. These are large, of loose graceful build, and of a bright blue lavender, very clear, and very clearly contrasting with the central boss of clean gold. Few plants of this size are more attractive, and very few Asters have the same clarity and effectiveness of colouring. But $I$ have not yet arrived at the supreme merit of Aster pyrenaeus. For it will grow everywohere-literally everywhere. And it will grow best of all in shallow water or in the wettest part of the bog. I have it in dense masses in rich dry land. I have it in masses in the wild wood. I have it in masses above the marsh, and $I$ have it in masses in five inches of water. Nor does this treasure make itself a nuisance by spreading or seeding. It grows from one crown into a wide cluster, and that is all. When you want to increase your stock, all you have to do is to mangle off the outskirts of a big clump with your trowel. Every piece will grow.

Other big things that will prove effective are the new Saussurea atriplicifolia, for a dry, elevated bank of rich 
loam above the bog. This is like a great Thistle-say Carduus eriophorus, on a rather smaller scale-with big flowers of a maroon almost verging upon black. Stenanthium robustum is another novelty, to be planted by colonies in a similar place-whereas the Saussurea is most effective as an individual. Stenanthium is so new that I can say little about it. The leaves are long and grass-like, and the flower stem, of four to six feet, is said to carry huge hearse-plumes of foam, that develop, from a greenish shade, through pure white to pink. As for the Gayfeathers, I have never seen a Liatris I would willingly admit to my territories. They are brilliant, with their long close spikes of blossom, opening untidily from the top, and they all thrive robustly in or near the welldrained drier parts of the bog, in deep nutritious loam. But in all the varieties, the colour is of too pungent a magenta to be anything but a pain. Xerophyllum asphodeloeides is another North American, just what its name implies-an Asphodel with greyish grassy leaves and spikes of white flowers, far more brilliant of colour. Near the bog this does well in deep sandy peat, but I have never had much joy or triumph of it; and I positively dislike its type, the true Asphodel, a gawky thing with spikes of dingy dismal and white, sodden and ghostly enough in tone to be, indeed, the phantasmal flower of the underworld-though, for that matter, no Heaven would be Elysium for me if it grew no prettier flowers than Asphodel.

The Phloxes, suffruticosa and decussata, with all their innumerable gorgeous varieties, do not belong to me to treat of, although no more glorious denizens of the bog could possibly be imagined, and though, in hot dry climates, there could be no better chance of enjoying the florist's Phloxes than by using them as bog-plants, in damp rich soil. However, I quail from trespassing on 
the ground of the dealer in herbaceous stuff-so will slide past the tall herbaceous Phloxes with a mere comment that late summer holds nothing more richly splendid than 'General von Heuzst'-the spelling is uncertain in all catalogues-sparkling cherry-rose, with a clear white eye-flowering profusely too, in mounded heads of circular flowers, and striking the eye, in a mass, from quarter of a mile away. And this is only primus inter pares, where almost all are beautiful.

Now, last of all, comes my plaint for Lysichiton kamschatcense. This plant, of daunting title, is very likely not what I mean, though; Kew's Lysichiton has the foliage of my lost love, but its flowers, I am told, are yellow. Now this is the tale of my discovery and loss. After a long toil amid the solfataras of Noboribets', in the Hokkaido, I was returning, wearied, through the calm twilight of a grey day, when I came suddenly upon a sopping bog, filled with pools and gleaming stagnations of wet. And, dotted about over the pale expanses, were starting up, on stems of an inch or two, great snowy blossoms exactly the size and shape and colour of Calla ethiopica. As soon as the flowers were over, up would come the leaves. I saw them, on advanced specimensopulent, splendid fans, exactly like those of Musa Ensete. You may imagine how eagerly, with pantomime and gesticulation, I procured me, from an Aino villager, a spade or mattock that must have been twin to that with which Cain killed Abel; how, with this primeval implement, I raked up the stinking depths of the marsh, to get a few plants with their vast white roots intact: how I sent them off, with elaborate directions, to be grown for me in Yokohama. And how, of course, amid the torrid heats of that pestilential place they all unanimously expired, and I have never since been able to acquire that precious plant in a living state. True, I 
got live pieces of Lysichiton from Canada last summer; but they also died, and besides I am not perfectly certain that my discovery in Hokkaido was ordinary Lysichiton. In any case, it was a big Aroid, with the habit of Lysichiton and Symplocarpus, flowering before the development of its enormous leaves. But those flowers, I maintain it, were snowy white-far different from the malodorous dingy purples of the Skunk Cabbage; which, otherwise, I will concede, is a fine easy foliage plant for the bog-garden. 


\section{CHAPTER X}

\section{马) tíg}

I HAve already sung the song of the Irids, of those that dwell favourably and fittingly upon the rock-work; but of the stately species that remain, there are many that must have a place upon the upper and lower slopes of my bank. First, as to exclusions : all the German Flag-Irises, all the bearded Irises, Statellae, Ciengialtii, biflora, sambucina, pallida, hexagona and pearly florentina are best fitted for the open border and for deep soil on the higher, dryer shelves of the big rock-work. So also are the smaller species of the group, attica, bosniaca, and the rest. Nor can I distinguish accurately and describe; as my Irises arrive, I cast away their labels in a frenzy of dislike for such disfigurements, and in arrogant hope that I may perhaps remember the different kinds apart. The result is a state of chaos with which it would take a specialist to cope. Not to mention that the nomenclature of Iris is unsatisfactory. I know that my tricuspis-a pretty grassy thing, with purple, tricorn flowers-is not genuine; I suspect my tolmieana too, and hover in doubt as to many of the others. What of a small intermediate Flag-Iris with big flowers of a curious greenish yellow, like blown glass; am I right in daring to remember that this is attica? It arrived in a bale from Servia, hung about with indecipherable labels, and I know that attica was comprised in that consignment, which also concluded 
bosniaca, as well as two others, whose very names have long since perished from my memory. These are for the dry rock-garden; so are intermedia and pretty violetflagged Fieberi, of small stature and splendid bloom; and all the Rohais hybrids, too ;-in which, for the rest, I am disappointed, their growth being very lavish and leafy, their flowers rather dull and undistinguished by comparison.

But before I go on to the Bog-Irises themselves, it will be but common decency for me to find places on my bank for the large Flag-Irises. Germanica itself-the old common type-plant, with its tall stems and its great glorious purple flowers-is worthy of our-humblest gratitude; it is no less amiable in good soil, high on the slope above the bog, than amid the sooty, cat-hunted wastes of a London Square. It has produced innumerable varieties and hybrids, of course, intermarrying freely with its close cousins in the bearded group; but none of the children, to my taste, surpass the robust imperial splendour of the type. Indeed many of them grow poor and indeterminate in colour, developing a small, wizened fall, far inferior to the flopping purples of germanica, so amply graceful in design as well as magnificent in colour. For the bronzy, yellowish, fulvous, mottled hybrids of germanica I have no use. Innocenza, white as its name denotes, is beautiful, and others, of old raising, have full form and fine colour. Madame Chéreau, the edges of whose snowy, frilled falls are pencilled most exquisitely with pale azure, is another beauty, long established, but not to be ousted by new-comers. Yet Madame Chéreau is not a germanica pur sang; and, besides, for all her dainty loveliness, has not the full, unhusbanded length and stretch of petal that marks the best of the German Irises.

Germanica, however, is flanked by two formidable rivals in florentina and pallida. So well known and well 
beloved are these, that there is little need for me to describe the big pearly flowers of florentina, rising up on stalwart spikes above the robust masses of foliage; nor the high-bred charm of pallida, twin to germanica in shape and size and habit, but bearing flowers of a soft, clear lavender blue like that of the Sweet Pea, Countess of Radnor. But pallida rises on stepping-stones of itself to higher things: pallida dalmatica, pallida Princess Beatrice, and pallida Mandraliscae are glorified versions, finer even than the type pallida; indeed Mandraliscae, with enormous blossoms of that gentle lavender, rising high above the greyish sword-like leaves, on towering spikes, is, I think, the finest of all the ordinary GardenIrises. Most remarkable of all, too, pallida gives a variegated variety which is genuinely beautiful. I only know the silver-striped form, but there is also a variation with golden stripes. But a well-grown mass of silverstripe is a notable addition to border or large rock-work, the pale grey leaves, all slashed and lined with white, contrasting in double beauty against the sheaves of pale lavender flowers above. And close to this may well stand a robust, beautiful cousin of germanica, Iris Kochii of the same ilk, with abundant big flowers of a dense rich violet. Nor are any of these varieties at all inferior to the type pallida or the type germanica in freedom and vigour both of development and blossom. As for florentina, the same praise belongs to its robustness and goodtemper; it gives no variety that I know, but no one who has ever seen it rioting on the edge of Olive gardens in Provence will feel a grudge against it for that. Nothing could improve upon the type. I have, as I told you, married it to my beloved tectorum, and though last season was barren of blossoms, reasonably hope for results this year. But a cold terror holds me against my will. Irises, it is admitted, hybridise readily, and the seedlings flourish 
like weeds, but sometimes they utterly refuse to floweryes, although they may have grown into masses many yards in width. But perish this disheartening thought! Down with it into the depths of the darkest cupboard at the back of my consciousness !

Of the larger bearded Irises little more remains to tell. There are some fine garden hybrids, of which Queen Emma and Queen of May stand pre-eminent. Statellae is of medium size, with globose flowers of sulphur-yellow; sambucina is particoloured and not conspicuous by the side of germanica and pallida; as much may be said of biflora, subbiflora, intermedia. But I have a magnificent stout Unknown from the shores of Como, which, at present, I suspect of being nearly related to pallida; this is very stalwart and tall, with leaves as fierce and broad as a Phormium's, and rare illustrious flowers of a lavender that verges towards rose. Finally, of all these bearded Irids, there is not one that will not thrive like grass in any deep, well-drained soil, in any open, sunny aspect.

Of the bulbous Irids I will now speak, but with tenderness and the delicacy of Agag. Indeed, in all I say on Iris, I hope I may be understood to be speaking with the most shrinking modesty. I am in no sense a connoisseur or specialist on Iris. I specialise on too many other things; and, besides, my anti-Irid climate forbids. Therefore, though I have a number of species and varieties, they are for purposes of decoration only, not collation; and I wander helpless among their names, as a sheep that has no shepherd. Therefore let my unknown correspondents, whose letters I so enjoy, be kindly in their comments, and not scold; respecting my intrepidity more than they reprehend my ignorant rashness in venturing on so tangled a topic, of which, perhaps, they themselves are perfect masters. The Irises are a difficult 
race; and $I$ only speak of them now loosely, and for the purpose of guidance as to the adornment of the garden. Well, as to the bulbous Irids, alata, histrio, bakeriana, histrioeides, orchioeides, taurica, persica, Heldreichi, reticulata and their kindred, hardly one of them is for me. For sharp, rich, sandy soil, for perfect drainage, for dry cold winters, for fierce, baking summers, all these are treasures of loveliness through the griping early days of January and February; and those who revel in such conditions may also revel in the bulbous Irises of the Levant. Here it is impossible for me to supply drainage keen enough, a summer warm enough, a winter dry and cold enough. My conditions, in which Primulas and Gentians rejoice, is slow death to the bulbous Irids; they barely endure the long, soaking dreariness of autumn, the wet, open mildness of winter; and then, with early spring, they send up, perhaps, one hesitating, frail flower. A slug takes it as a hors d'ouvre, a mouse for dessert; what is left-a flapping, torn relic-is washed threadbare with spring rains, and splashed with mud until its original design and colour can only be guessed. Next season, of course, the wretched bulb prefers death to another such unprofitable effort. One, only, has to be excepted from this dreary list. Iris reticulata approves of me, and occasionally, for some mysterious reason, prospers most unreasonably. In one dank, shady border, there is a bulb that flowers obstinately from year to year, and neither dies nor increases. And, throughout the garden, I am liable to outbreaks of unsuspected Iris reticulata every season. Perhaps of all the bulbous species, too, reticulata is the loveliest, with its thin rush-like leaves and its three-pronged flower of intense violet, eyed with orange, and scented with the fierce deliciousness of the violet whose colour it imitates. Leichtlini is larger and paler, and the major form of reticulata is also well spoken of, but the type reticulata is 
not easily to be surpassed. As for the Irises of the tubergeniana group-sindjarensis, willmottiana, orchioeides-for these I should never have any use, not even if I dwelt in Paradise and found the winters suitable. These Irises are all of a densely leafy habit, and, from the spire of flopping foliage, pierce flowers which, by comparison, are insignificant and dull. Iris minuta and Iris arenaria are novelties yet, of which $I$ have no chance to speak. Minuta is but newly arrived from Japan, and I expect more from it in the way of health and charm than I do from the sand-craving arenaria, which, from its habit, threatens to be an abhorrer of damp.

The Irises of the grass-leaved group are rather incalculable than difficult. The first in importance is Iris unguicularis, more commonly known as Iris stylosa. Few plants differ more in habit according to circumstances. In the South of France you will see it used as the edging to beds on the blazing Mediterranean slope of Provence, and there its foliage sinks into utter minute insignificance, and the whole edging is a solid line of what looks like magnified brilliant blossoms of crocus iridiflorus, dowered with a delicious fragrance to which the Crocus is a stranger. Then, again, you will see Iris unguicularis thriving in an English garden, making a tall, close jungle of leaves, lush and lanky enough to be confused with the dishevelled clumps of the common Gladwin. And there, far down in the thicket, nestle here and there the wide sweet lavender cups of blossom. In point of fact, the intense heat and sunlight of the south are the plant's favourite conditions, minimising leafage, and educing the most reckless generosity in the matter of bloom. But Iris unguicularis is of accommodating temper, and, with any fair treatment, in good light soil, in an open position, sheltered from the worst violence of the wind, it will prosper and develop as imperturbably 
as any native. There are now scores, if not hundreds, of gardens all England over that possess big established tufts of Iris unguicularis, as solid and autochthonous in appearance as if they had come over from Normandy with all our ancestors in the train of Matilda Duchess. The more sunshine you can give it, of course, and the more exposure to sun, the better will the plant thrive and bloom. But this sun-loving Algerian is as hardy as anything need be, and will never suffer from any English winter, unless you have been very brutal to it indeed in the matter of soil and situation. Further, the dense, spidery leafage into which our shadowy English climate leads it has one very favourable result, for the exquisite blossoms, peering up as they do into the sere, dead eye of midwinter, must undoubtedly be ravished and spoiled and dishonoured by rains and storms were it not for their protecting nest of foliage, which would be so unnecessary under the brilliant clear winter of Algiers. As for the white unguicularis, it is a flower straight from heavena transcended snowy Crocus or Zephyranthes. The plant is choice, but not much more delicate than the typethough, being rare and so exquisite, it has a right to extra-special attention in the matter of soil, site, and guardianship.

Iris graminea and Iris prismatica are, roughly speaking, miniatures of unguicularis, blooming in early summer, on short stems, amid a thin jungle of long grassy leaves. The flowers are large, of thin build and design, in varying shades of purple. The prettier of the two, I think, is I. graminea, which has a fine, hearty fragrance of plums; but both are perfectly easy to grow in any open place on the rock-work, where they go on for many years and never need any attention beyond, perhaps, the occasional stimulant of a little fresh, rich soil. Iris douglasiana is a rare, new North American, of whom I can say little. Iris 
tenax and Iris versicolor are also grassy-leaved Americans, of which tenax, I fancy, is the more brilliant. But I have not yet done any great things with either. Iris virginica I mention only to contemn, and not because it belongs among these grass-leaved kinds. In foliage virginica is a straggling germanica; in flower it is too often a small, wizened tubergeniana, which, by contrast with the rank, tall, leafy growth, is almost insolently mean and poor. Iris hexagona, which I only grow in its superior form Lamancei, is a puzzle to me. This is a very beautiful species, I am told, of medium size. But I rather fancy it hails from Southern China, and its constitution is not altogether beyond suspicion. In any case I have had Lamancei now for many years, dwelling perpetually in the same favourable spot, and never advancing or retreating in prosperousness. It remains rigidly as it always was, and quite declines to flower.

Of the Oncocyclus Irids I have already made my sad plaint. Nor have I a more rosy tale to tell of the Regelia section, which is supposed to be a shade easier and stronger than the Cushion Irises. Among these difficulties there are two, indeed, that I yearn to cultivate successfully-but never for me is such a golden fate attainable. The two are susiana and Korolkowi. Susiana is the gigantic, flag-flowered Mourning Iris, which must have delighted Queen Elizabeth, so long has it been in culture over here. This gorgeous Levantine revels in hot, baked sand, and prospers, for instance, most riotously, I believe, in the archiepiscopal garden at Canterbury. But with me it will never do any goodalthough it is a compatriot of Niobe, with whose lachrymose habits one would have thought my summers and winters so harmonious and sympathetic. Never, never, I fear me, shall I behold those vast, swelling flowers, exactly like inferior, flimsy blotting-paper, all blotched 


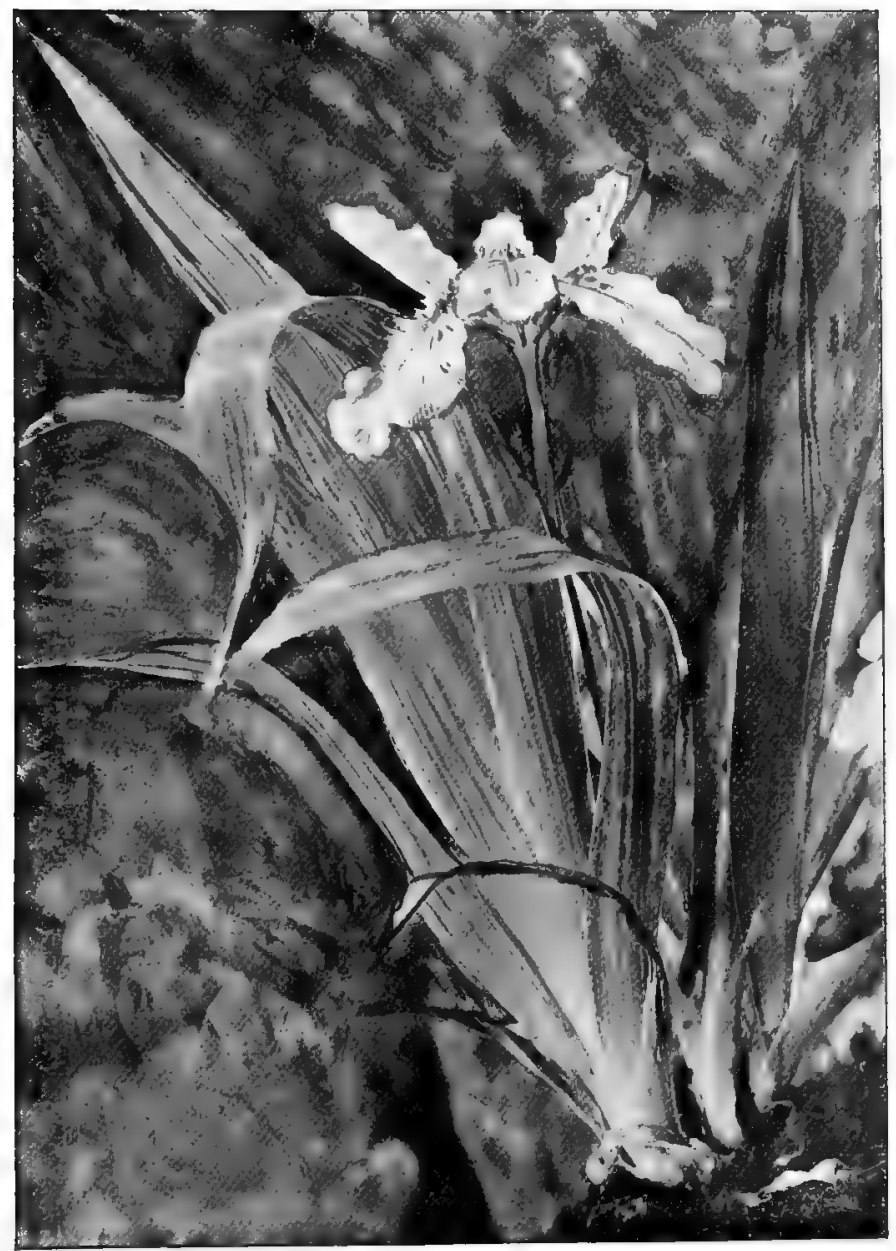

IRIS TECTORUM. 

and lined and streaked and splashed and mottled with inferior ink.

As for Iris Korolkowi, this alone among its capricious kindred has really stirred my love and enthusiasm. I can make a manful stand against the charms of Iris paradoxa, I can even bear up against the beauty of Iris Lorteti with not more than a shooting pang of envy, but I collapsed utterly on my first sight of Iris Korollowi. This, in its best forms (the inferior, ordinary ones are dull and comparatively uninteresting), is a slender grower, rising to a couple of feet at the most, and bearing one or two elongated, gracious flowers, whose colour is an indescribable mixture of fawn and brown, with the clearest, gentlest, electric blue. I would go any lengths to grow this, but I never have. Like all its kin, it clamours for light, limy loam, fierce drainage, hot summers, and dry winters-a hopeless demand to make on me. But, given these requirements, none, I think, of the Regelias and Oncocyclus groups can be fairly accused of half-hardiness; genuine half-hardies are Iris sinenis, or fimbriata, and Iris Milesii, of which fimbriata, common enough in Japan, is an enlargement of my heart's best love, gracilipes, and Milesii, a diminished, inferior form of tectorum. As a matter of fact, as fimbriata is common in Japan, it should be quite possible, if it were worth while, to get plants from some cold district, and so make sure of having it perfectly hardy in England.

Dainty Iris nepalensis, of which Mr. Eden Phillpotts writes with such enthusiasm, I have never yet possessed; nor, if I did, do I believe I should succeed in keeping it for long. As for the new Regelio-Oncocyclus hybrids, I have read flaming advertisements, I have ticked off their names amorously in high-price catalogues, but I have not hitherto bought any ; their names are classical and fitting, which is a rare mercy in the garden ( $O$ namer of these 
Irises, my heartiest thanks and sympathy to you !); and one is strongly tempted by Charon, Aspasia, Iphigeneia. And yet, and yet, from what I have so far seen of these trumpeted beauties at Horticultural Shows, they might more suitably be called after Mrs. Smith, Mrs. Brown, and Mrs. Robinson. Truth to tell, they have, so far as I have seen, large and rather undistinguished flowers, coloured in those dim, indeterminate, and muddy tones which pass muster for artistic to so many aspiring tastes. For these, as for the many hideous intermediate pinks and magentas of the newer Oriental Poppies, let all who ignorantly crave after fashion grow ecstatic; true gardeners will always know without telling that a flower's one claim to beauty and adoration rests in its unstained clarity of simple or combined colour. Nor does this definition exclude the subtlety that is such a charm in Iris Korolkowi, Dianthus neglectus, Anemone robinsoniana; nor, on the other hand, must subtlety ever be confounded with mere muddiness of tone and lack of any definite colour at all.

Who is there in England that grows Iris setosa and Iris laevigata? And yet of these two ignored parents has been born the Iris of all Irises, the Iris of Japan. Iris Kaempferi takes the stage with a brazen flourish of trumpets; there is nothing like it in the garden for arrogance, for subtlety, for obviousness, for sheer insolent violence of beauty. No taste, not the most crude and immature, not the most delicate and over-refined, can refuse its homage, its instinctive, gasping homage, to the first glimpse of that royal Japanese Iris. Its appeal is almost scornful in its innocence of all appeal; you have to worship the thing, whether you will or no, and the plant condescends to no wiles to conciliate your feelings. And the heartless splendour of Kaempferi has its reward. One adores it as something supreme, one loves it reluc- 
tantly, abjectly, as something irresistible; one never dares feel tenderly towards it as towards Iris gracilipes, or absorb oneself happily in its loveliness as one can sink deep into the sympathies of Iris tectorum. It is the difference in personality; one might as soon dare to feel tenderly towards Queen Elizabeth-proudly, gloriously, adoringly-yes, but it is only for the milder, softer, weaker beauties that one may feel tenderness. The others claim our worship from on high, from the exaltation of a superior sphere; only the gentler lovelinesses appeal to us on our own plane, and, in their meek appeal, pay a subtle compliment to the strength of our own natures. And, if it be a vain fancy to find personalities in flowers, then many gardeners, I believe, staid and respectable people, are guilty, in their secret hearts, of vain, delightful fancies. And therefore I make no defence or apology; those who understand will sympathise; those who do not understand would never do so did I explain and analyse till all the plants in all the world had run to seed and made way for altered forms. To take the Violas, for an instance. Always, to me, the gentle face of Viola calcarata is the face of that gentle, ineffectual Renata d'Este, who begs." d ended her life so much more happily as Renée de Valois; Viola biflora, quiet, shy, recondite, is 'cette pauvre jeune reine Jeanne' who moved Diane de Poictiers to her one flash of emotion; as for Diane herself, respectable, prosaio, and solid, where will you find her soul but in some obese Pansy in a border? And Viola pedata, freakish, whimsical, humorously sad and tender, surely this is the Margaret of Margarets herself, My Lady Margaret of Angoulesme and Navarre; so Iris Kaempferi, audacious, arrogant, short-lived, is a memory of Queen Anne Boleyn, enshrining the ambition, the self-sufficiency, the violence of that indomitable nature. 
A proof of the brilliant scornfulness inherent in the Japanese Iris may be found in the undeniable fact that it will never tolerate being mixed with other plants. The Japanese Iris has no place in the garden, no place in the companionship of the bog. It must have a tract to itself, and be planted, not in isolated clumps, but in tracts and masses. Then, perhaps, you may arrange Trollius among it for early summer, and Gentiana asclepiadea to come on in August and September; but it is always fatal and ridiculous to plant the Japanese Iris in individual crowns among commoner neighbours. The Japanese themselves fully recognise this, and in all gardens, public or private, Iris Kaempferi has a broad bed to itself away from other things. There is one exception, of course, to this rule, and that is that a lonely clump of the Iris is allowed to look superb, to strike the keynote of the whole composition, when set by itself, in a commanding position, on the edge of some lake, at the bend of some stream. But even here the rule holds good, and the effect depends on the complete isolation of the Iris. Any companionship of weaker lines will ruin the whole scheme at once. No plant in the garden has quite the same mixture of stiffness and grace; the sheaf of slender stems, all of arrowy straightness, scarcely diverging as they rise from their common base, give a clean, fierce strength of line to a clump of Iris Kaempferi such as you will see nowhere else. A good crown of Bambusa nigra, indeed, has the same grace, and more divergence, though it doubles the grace at the expense of the stiffness, and so loses the tart elegance, at once crisp and archaic, that delights one in the decorative force of the Iris. Of course, planted in masses and rows like potatoes, one loses this effect. But then one barters it willingly, perhaps, for the blaze of colour that results from such an arrangement. This is how you see Iris Kaempferi in the 
gardens of Horikiri-a little, shallow vale of an acre or two, a river-spate, in its time, of blue and purple splendour, where the Irises are so crowded that hardly a leaf can be seen, rari nantes in gurgite vasto of that swirling kaleidoscopic tide. And dotted here and there are little summer-houses of wood and thatch, open on all sides, where one drinks pale tea brought by Elder Sister, with a painted fall and a few Iris blooms wrapped up in paper -and then writes poetry to the ecstatising glory of the flowers all around.

There are many schools, schisms, heresies, heterodoxies as to the treatment, in England, of the Japanese Iris, and, by dint of all these, the plant has acquired a doubtful reputation that I do not think it deserves. There is, to start with, one great predominant Dos'r in the culture of Iris Kaempferi. Never plant it in shady places, in hollows of the wood, and so forth. If you do this it will possibly grow well and permanently, but it will never flower, or very rarely. It is dependent for its bloom and general welfare on complete exposure to the sun (at least this is my firm and pious, though humble, conviction). After this, all is uncertainty. I have even heard of Iris Kaempferi rioting in beauty on a high, hot, and sandy slope (history did not say how long it continued to do so, urges my scepticism). I have heard of it, I say, luxuriating or failing, in the most improbable places, and altogether the question seems as hopeless of final canonical settlement as that of the right culture for Lilium candidum. Perhaps, like a theological dogma, or the cat's inquiry about the historical precedence of owl and egg, there is no real end or answer, no definite, unalterable right or wrong.

There is one consideration, before I try to deal with the matter by the light of my own experience, that, I am sure, has helped to shed doubt and uncertainty over the 
plant's requirements. Iris Kaempferi, in normal circumstances, takes two full seasons, if not three, to become established and show its true character, no matter how favourable the site and soil in which it has been put. And some gardeners, seeing their plants apparently languishing, although in excellent conditions, have probably despaired too soon, and thrown the plant up as a bad job; whereas, had they been patient, the Iris would have come to its own in its own good time. Again, in a bad situation, the Iris is capable of making a wild morbid display in its first season, and then dying outrightfollowing nature's law by which a moribund plant tends to throw its expiring forces into a last desperate outbreak of blossom, before inevitable death descends. This trick is deadly and delusive, with its fallacious suggestion of prosperity; and some growers, finding their Irises a miracle of bloom the first year, and dead corpses the next, may be too prone to condemn the thing, offhand, as capricious, incalculable, and unsatisfactory.

Now, as to the culture at Horikiri, where the summer, I'll remind you, is wet and torrid, the winter dry and icebound. Here the Iris is grown in fields of liquid manure. All through the growing season water is admitted as into a rice-field. Then when the flower-buds are forming the water is cut off, and no more is admitted till the next spring, leaving the plants as dry as the climate will allow all through summer, autumn, and winter. The one thing certain is that Iris Kaempferi will never grow well and permanently in water, but must be treated as an ordinary dry-ground plant, during about three-quarters of its existence. From my own experience I should be inclined to say that the most important point to aim at is thoroughly efficient planting at the outset. Make your soil as rich as you can possibly make it, and as heavy too-though of course with efficient 
drainage. Then get sound young crowns of the Iris, put them in and leave them patiently alone, only taking care to keep them clean of weeds and grass-a companionship that the haughty creature hates. On the question of moisture I am not inclined to be Rhadamanthine; in my own moist climate I have not specially troubled to keep the Irises supplied with special extra moisture, though, in both gardens, my tracts of Iris Kaempferi lie in and out of the bog. If the soil is heavy and rich, almost enough has been done: the roots are secure against starvation and drought. And my own suggestion would be that more harm is done to Iris Kaempferi in England by overattention in the matter of water than in any other way. Grow it in very cool, rich, heavy soil, open to the sun, and leave it undisturbed. Then, provided your climate supplies a certain amount of rain-especially in early summer-you should do well. And, of course, if your climate be fatally dry, you will have to supply some artificial moisture. But not, I advise, too much, nor too persistent. People who see a plant blooming in a bog are too apt to conclude that it requires soaking wet all through the year; as a matter of fact many, if not most, bog-plants enjoy their season of comparative dryness.

Few cultivated plants have a wider range of colour than the Japanese Iris-ranging, as it does, from the creamiest pure white, through every shade of mauve, purple, and imperial violet, to a blue so intense as almost to verge on azure. But I would--this as a matter of personal taste, not of doctrine, and therefore not entailing thirty-nine distinct damnations if you trip upon itthat you exercise care in your choice of Japanese Irises. Do not buy job lots, do not buy unnamed sorts, or named sorts without description. For there are many double and semi-double varieties, and there are also very many mottled, splotched, splashed, streaky forms-even more 
like bad blotting-paper than Iris susiana-which, to be truly complimentary, really recalls a piece of grey Japanese silk-crape. Now there are many who adore these mottled horrors, for mottled horrors I will intolerantly continue to call them ('and I wish they was in Jonadge's belly, I do'). For such let them abound; I merely offer my warning to those who love, as I do, clear, clean shades of colour. As to the double and semidouble forms I dare not speak so drastically. I have seen some hideous ones, tight, bunchy, voluminous, devoid of elegance or beauty of line; I have also seen some very stately ones, like huge blooms of Clematis. On the whole, I would eschew double varieties entirely, and keep an open mind about good, graceful semi-doubles. For the benefit of those who see Iris Kaempferi in Japan I would here note that the exquisite crimson-veined white and pink ones that one sees and pounces on out there are not genuine varieties, but dyed, for the time, by insertion into some acid. So that the lot of those who purchase plants of these delusive lovelinesses is hard indeed, and pitiful.

Iris Sibirica introduces us to a very valuable group of Irises which are genuine water-side plants, and quite invaluable for the edge of stream or bog. They are all of the easiest possible culture, the utmost good-nature and the most imperturbable permanence, needing no attention at all from year to year, and quite capable of being naturalised in some choice corner beside water. A very strong family likeness marks them all, and sibirica is their type-a slender tuft of dense, straight, slim stems, carrying along their course half a dozen beautiful and beautifully-shaped blossoms of pale blue, veined and marbled all over with a deeper shade. Major, orientalis, longiscapa, sanguinea are all varieties, of which the best is major, having larger flowers than any. Then there is 
a pale blue form, and a snow-white one, and a new improved albino, Snozu-queen, which, like major, has the advantage of larger flowers-the one weakness of sibirica being that its very pretty flowers, besides being individually short-lived, are also rather small for the height of their stems. Finally, I have, from a neighbouring garden, plants of a giant sibirica, which originated there from seed, and proves far and away the largest and the most solidly brilliant of the group. Of the rare new Delavayi I cannot say much. It is a later, largeblooming cousin of sibirica; but I have never been at home when my clumps bloomed, and therefore cannot describe them except to say that they persist. Probably, too, it is more nearly related to the tall sword-leaved bog-species, of which gigantea is the chief. It is with sibirica as with Kaempferi; the plant, as a rule, is better in bulk than as isolated specimens. Its greatest triumph is when arranged as a loose chain of tufts down the winding shore of some lake or little stream. My own memory of it is at daybreak, in levels round the shallow end of a Japanese lake. The solid earth was all a waving sea of blue Iris; and, beyond, the pale water of the lake lay motionless without a ripple, carrying the flawless reflection of Fujiyama, pure in snow, a dozen miles away through the clear breathless hush of dawn.

Of the other Japanese Irises, I can but mention my glimpse of a conspicuous deep-sapphire one, tall and stalwart, of the gigantea kindred, I think, which I saw one day on my way up to Nikko. And then there is the rare, rich albo-purpurea, which has recently come into cultivation, and seems to be now causing grief and searchings of heart. It is being, I expect, too much treated as a bogplant, requiring incessant wet. I should here repeat my suggestion about Kaempferi, and, to foster confidence, will here mention, rather late in the day, perhaps, that I 
have certainly made a fine and permanent success of Iris Kaempferi. It is early days, as yet, perhaps, to say so much of Iris albo-purpurea, with its white variety ; but, as far as I can see, under the same treatment as I gave Kaempferi, these rare beauties are now advancing on the same happy way, and I look forward, this season, to their big white and purple blossoms. And last of all comes an Iris near sibirica, which I bought at a Night-Fair in Tokio, and which has since developed into two enormous bushes of narrow, flopping foliage, emitting from their thickets a sheaf of tall stalks with disproportionately large flowers, opulent, solid, creamy-pure.

The Spanish and the English Iris are both bulbous, but of cheerfuller temper than any of their cousins from the Levant. However, except for light dry soils, in light dry climates, I would hardly recommend Iris xiphioeides as a certain perennial for the rock-garden. Far different is it with the gorgeous old English Iris, whose huge, deep azure flowers make the pride of many a cottage-garden. Iris Xiphion is, I believe, a southerner and Spaniard of very limited distribution, and yet this outlander has so happily established itself with us as to have acquired the ridiculous name of English Iris (while, by another ironical paradox, it is the Iris called germanica that is the Royal Lily of old France). Iris Xiphion has many varieties in the way of colour, but none, to my mind, touches the common midnight blue-which has the further pride of being the most vigorous of the many vigorous forms of $X i p h i o n$. All it requires is to be let alone for ever and ever in any good garden loam; and in crowded, rough corners of the rock-garden it makes a splendid patch of colour, which may punctually be relied on to appear each season with the coming of June.

Xiphion and xiphioeides bring one back to the triceratops form of flower-the triple prong-as distinguished 
from the fuller and more satisfying rotundity of the flagshape, and from the clematoid broad magnificence of tectorum and Kaempferi. Others of this persuasion are of prime importance for the large bog; and of these the sovereign is Iris gigantea-the tallest grower of all, with immense great sword-like stiff leaves, and big flowers of creamy-white and orange, which are only just not big enough for the stature and general appearance of the plant. This, with all its cousinhood, is an easy and splendidly persistent plant in any cool moist soil, making a fine feature at the head of a lake, or in some deep damp nook, with its eight or ten feet of height, and its keen, fierce foliage stiff and stern as a New Zealand Flax. Similar, but not quite so great and high, are longifolia, aurea, Monnieri, spuria, their hybrid Monspur, and another hybrid called $A$. J. Balfour. Then comes the smaller Iris cuprea, with which I have never done much-more from lack of effort, I think, than for lack of anything else. Then with regard to our own two native Irisespseud-acorus and foetidissima, let me enter a word of caution. Foetidissima is merely dull and harmless, with attractive seed-pods that open in autumn and winter, revealing rows of brilliant scarlet seeds amid the sere foliage. But pseud-acorus is a cunning creature, against whose wiles one must be watchful. It looks so mild and innocent that one admits it to the garden for old sake's sake. As soon as it gets there it sets to work growing like Jack's bean-stalk, and seeding like a groundsel. Years of effort will hardly rid you of the common yellow Flag-Iris, if once you admit it; and I assure the believing that $I$ have seen it, under cultivation, grown to twice the stature of a full-grown man, an enormous, tropical-looking weed, making the Aloes ashamed, and wiping the Phormiums off the face of the earth. With what wrymouthed disgust did the poor gardener contemplate that 
gigantic invader, that overgrown cuckoo which he himself had unwittingly introduced into his pleasure-ground of choice rarities, and now could not hope to be quit of, except with dynamite and digging enough for the foundations of great Babylon. And the moral of this tale is, always be very careful how you admit a native into cultivation. You never can tell when, instead of a meek angel, you will find yourself entertaining a rampant devil unawares, and totally unable to be rid of him. 


\section{CHAPTER XI \\ The glountain $2 B o g$}

AND now, having clothed the high banks and outlying copsy slopes of our ideal dell, let us gladly come to the furnishing of the choice open space in the middle, where a tank of concrete, as large as you can make it, has been filled with light and pleasant soil, provided with drainageholes and outlets, and given a gentle little brook to meander across its surface. Not, as I have said beforeand now repeat for the encouragement of the dispiritednot that the concrete tank is at all inevitably necessary. If you have drainage, and running water, and light rich soil, you will have no need of it; the concrete tank is simply my ideal precaution which can never do any harm, and which may, in a blazing climate, devoid of rain, and on a parching sandy soil, devoid of nutritious elements and running water, give you lasting joy in a bog-garden where you otherwise could not have one at all. Of course, where ideals are to be talked of, probabilities no longer count; and I will now be brave enough to say that in my own dearest, most private ideal, the choice bog-garden shall not be, as I have so far timidly pretended, in the depth of a shallow dell or hollow, ringed in by lush leafage of lily and fern and giant harebell. No; it shall be high up-high, high up, on a bare shoulder of the rock-work. Behind it lofty cliffs of stone shall converge to a cañon at the end, through which a 
stream shall come Lodoring, to disperse itself in runnels over the shoulder, and to leap thence, down a steep precipice, into a little lake below. If you are, by some monstrous favouritism of the gods, blessed with such a golden possibility as this, I will smash the Tenth Commandment first, and hurl its fragments at your head; but $I$ will then be generous and confess that you will have the loveliest bog-garden in the country, if you fill the open space between your cliffs with stone-chips and light soil, surfacing it, too, with larger flakes and debris of the mountain limestone. And then, and then, on that rock-strewn shoulder, permeated with running moisture, incessantly, violently draining downwards, you will plant every glorious little bog-plant of the highest Alps and Himachâl, and they will glory in so delightful a reproduction of their own chosen dwelling-places in the hills. Thus, if you are lucky in avoiding the neighbourhood of large incongruous features, such as trees, houses, or big shrubs, you may possibly attain the illusion of a high lonely corner of the mountains-and will, in any case, certainly be much closer to it than if you merely have your bog at the bottom of a hollow, with copse and woodland plants all round. But this cherished dream of mine presupposes so many things, as to stand beyond realisation by the general run of gardeners. The ordinary scheme is good enough, and only less good than the best.

But wherever you have your bog, I advise great attention to the surfacing. It is extraordinary to me the way gardeners cherish excessive stoniness in big stones (which are oppressive and ugly in effect), and utterly neglect the beauty and value of small broken chips. I am not now talking of the actual moraine-garden, which is too important thus lightly to be dismissed; but the ordinary rockgarden slope or pocket-the flat surface of the bog, are a 
hundred times more beautiful, a hundred times more verisimilar, a hundred times better adapted to their purpose, if thickly powdered with a surface of broken limestone chips, varying from the size of one's thumb to that of a baby's hand. These stones give drainage, preserving moisture, and carrying moisture away for storage ; they offer protection, nourishment and guidance to the wandering roots; they enable underground runners to form their natural scattered colonies; they afford coolth in hot summer, and comfortable assistance in winter. And all this, finally, because of their greatest recommendation. For it is among just such broken rock that all these Alpine little bog-plants grow in their native places, and it is amid just such cool grey flakes that their gentle brilliance of carmine, azure, or lavender shines most delicate and pure.

And yet, despite these obvious reflections, too many gardeners, luxuriating in superabundance of big, ugly rock, ignore the use and charm of small broken stone. The usual idea of a rock-garden is that of a wilderness of huge rocks, as big as you can afford, jostled together as close as they can stick, and then peppered with plants. Against this I would cry, with a loud voice, the paradox that in the rock-garden it is far easier to use too much stone than too little. Do not have a serried mass of rock; have surfaces of flat and sloping soil, with big stones suggested rarely, here and there, emerging perhaps in one bold crest or bluff, giving the restrained effect of the genuine mountains, which do not wear all their bones on the surface, but protrude them where they must, at worn, weather-beaten angles of their slope. Compared with these glorious originals, too many rock-gardens go astray in ostentatious superfluity of stone-yes, I must say it, from Sir Frank Crisp's luxurious compilation of rock, down through many a milder, smaller composi- 
tion. And if people would only realise how little stone is necessary to the good rock-garden, they would also realise, as one pleasant consequence among many, how cheap and easy it is to make a rock-garden. You don't want many rocks, nor mighty ones; you want skill and discernment in placing the very few you really require. Let this encourage many thousands more to cultivate Alpines.

I think that of all corners of the world the Alpine bog is the most wholly sparkling and deifying there can be. Hemmed in by the rich heaviness of tropical forests, I gasp and catch my breath at the memory of certain glittering Oread-haunted meadows, ten thousand feet above the ordinary world. The thought of them, amid the dense warmth, is a sudden plunge into water cold and clear and radiant as diamond; it arrests the pulses of the heart for a dizzy instant, then sets them leaping forward with redoubled zeal.-_Or perhaps it is the naked, lonely valley of Upper Tees, rolling away in mile after mile of purple and yellow Pansies, girt in by huge sluggish hills, and filled with a clean silence and an utter loneliness beyond imagination. Here, on broken places above the little bogs, shine in the short herbage wide stars of Gentiana verna. Here the soaking shingle of the streams is tufted with golden masses of Saxifraga aeizoeides, and on their banks rise the dull violet spikes of Bartsia alpina. Long and faithful search, perhaps, will show you treasures even more sacrosanct-fair frail Arenaria uliginosa, in the marshes of Widdy Bank, and Viola arenaria on dry patches of the upper slopes; or Saxifraga Hirculus, dwindling to extinction in the very stream-bed of Cronkley. High in black humus-bogs of the Fell lives tiny, fairy-like Thalictrum alpinum, and Rubus Chamaemorus makes carpets of its vine-like leaves over the upmost moors. 
Or again, perhaps, it may be a level tract I know, beyond the last white limestone pavement at the base of Ingleborough. The great mountain, close overhead, lies lazily against heavy cloud-masses in the west, the long sleepy lines of its eastern slope looming dark, in blue and violet, against the gloom behind. And at one's feet lies a strange ground, like the foundation of a vast Cyclopean temple, built so long ago, and so very long ago destroyed, that its very foundation-stones are now rubbed smooth and shapeless by the tireless persistence of wind and rain, through countless ages. Underfoot lie couched amorphous masses of white rock, flush with the soft fine grass, their flat surface worn and rounded into innumerable hollows, bays and inlets, held by invading vegetation, small and Alpine. Water pervades the place too, and shines in patches of pure silver here and there in the depressions of the boulder, or spreads in brown patches that reflect the sky and cloud above. And here, on the damp stone itself, Sedum villosum, lovely treasure in a tiresome race, lifts its large waxy stars of soft pink on tiny, two-inch stems; here the common Eyebright grows dwarf and pretty; here Primula farinosa illumines the greyness of the rock, the russet of the grass, with the rosy heads of her blossom; and here, in undrained hollows of each slab, where humus has gathered from a hundred thousand generations of dead plants, Arenaria gothica spreads his wee brilliant branches of green, and opens his big snowy stars. The place stands so high that its horizon seems the rim of the world. None of the valleys can be guessed; to the west the dominant mass of Ingleborough fills the sky; to the east, over the last edge of the upland, all that can be seen is the leonine bulk of Penyghent, far away across six miles and more of invisible valley and fell. And the silent loneliness of this stony level is august and absorbing; rarely, now and again, it 
is intensified by the whistle of a curlew, high above against the driving clouds, or completed by the desolate resentful wail of the peewit.

But more than all, perhaps, if any one will have patience with these cheap Cook's Tours of reminiscence, count in my love the bogs and streams of the highest Alps. Not above all, perhaps, for the very limitations of the English uplands give them a charm greyer and more subtle in some ways than the riotous, unrestrained fertility of the higher Alps. But the sombre magnificence of Ingleborough is sometimes harsh and cold and unconducive to one's moods; the glory of the Alps is always obvious and irresistible, at least to those whose artificial tastes are not repelled by the obvious. Alas that such things should be, but there are actually people who 'do not like the Alps,' who think them banal and chromolithographic! O pale cold hearts, corrupted with terror of admiring the obvious, whose jaded pulse will not let itself be stirred by anything that they cannot think bizarre, recondite, beyond the comprehension of the profane crowd! Thus, in their loves and hates, they are for ever flattering their own vanity, and proving to themselves that they are not as other men-a needless proof, too, for all I know who have hammered out this horrid heresy about the mountains, are people of such charm that they need no other claim to a pinnacle high above their tedious fellow-mortals. Yet, in this one vital spot they are weak, lacking courage to adore the easy. They are of the same blood with those who pretend that the rose and the diamond are not worshipful, because they are common. But $\mathrm{I}$ will not dive into an analysis of that mysterious and even incomprehensible state of soul which confuses beauty with rarity; I might dissect for ever without result. Instead, I will turn to those who have sound, happy minds, and now invite them to 
join me in my wanderings up the side of an Alpine rivulet, splashing through its bogs and luxuriating in its treasures.

At first starting, one meets the stream, a brawling torrent, foaming down through the pine woods. Amid the dense gloom of their branches the sunlight, here and there, pours shafts of brilliant gold upon the leaping snow of the stream, and, in rare patches of light the oakfern's green fronds shine with their almost unnatural brilliance of emerald. Round the roots of the pine-trees, in the unruffled stillness of their shade, spreads a thick soft carpet of moss, starred with the white waxen cups of Pyrola uniflora. So the course of the water continues downwards through the wood, and, as we mount, we pass through thickets of tall yellow Monkshood. Then, perhaps, along beneath a little cliff, stretches a bed of Lactuca alpina, luxuriating in the dankness. It is strange to see this stalwart, splendid plant, six feet high or so, crowned with a head of crowded purple dandelions, thus forming into broad spreading colonies, when one remembers that it still clings, in rare lonely specimens, to inaccessible damp rocks high up in the ranges of Clova and Lochnagar. And yet, in cultivation, it is no less easy than handsome, for any rich corner. Now, in the forest, we are in the track of many splendid, riotous water-plants. Perhaps we may come upon the very rare Hugueninia tanacetifolia, like a big yellow Valerian, which haunts wet wooded places in the Valaisan Alps. In any case we see the Valerians themselves, and, in more open places, the loose white stars of Saxifraga rotundifolia, stout and sturdy, or the palmate leaves and white showers of Ranunculus aconitifolius. And then, not at the water's edge, but up on the knoll of some decayed tree-stump, sprouts from the rotten soil one arching plume of Streptopus amplexicaulis, like a tall branched 
Solomon's Seal, with waxy bells and scarlet berries. On the same knoll rise the airy purple spikes of Prenanthes purpurea, and perhaps the Great Solomon's Seal itself. Polygonatum verticillatum occurs rarely, in isolated, small groups of three or four stems. Set apart from its kindred by the arrangement of its leaves in whorls, this graceful Solomon's Seal, always of local occurrence, is found in copses near Bellingham in Northumberland, and about the banks of the Tay. So far I have not made any solid success in the cultivation of it. Far different is the case with the May Lily, which now carpets the ground amid the oak-fern. Of Maianthemum bifolium, with pairs of glossy heart-shaped leaves, and fluffy little white spikes of blossom, I have always had the greatest pleasure, and now am naturalising it in the woods-an easy task, seeing that its one station as an English wild plant is in a wood at the other end of Yorkshire. Here and there among the May Lilies, in the darkest places, you may see the dingy, mud-coloured spikes of a little saprophyte Orchis, Corallorhiza innata, whose flowers are like sere, rotten imitations of a flower, cut, à la Japonaise, out of lard. This is impossible of culture, and its chief interest is that this, too, is a rare native of our northern woods. As for Epipogon aphyllum, weirdest and most monstrous of morbid beauties, with its fleshy, lurid flower turned the wrong way round (like that of Odontoglossum pulchellum), and its general aspect of bruised, decaying flesh, purplish and livid, this has only twice occurred in England, saprophytic on rottenness by ditch-sides in one Hertfordshire wood, and so incalculably rare is it all the world over that you may think yourself fortunate indeed if ever you come across it in similar positions near stream or hollow of a Swiss forest.

Now, as you mount, the torrent begins to course through more open land. The forest thins off, and you 


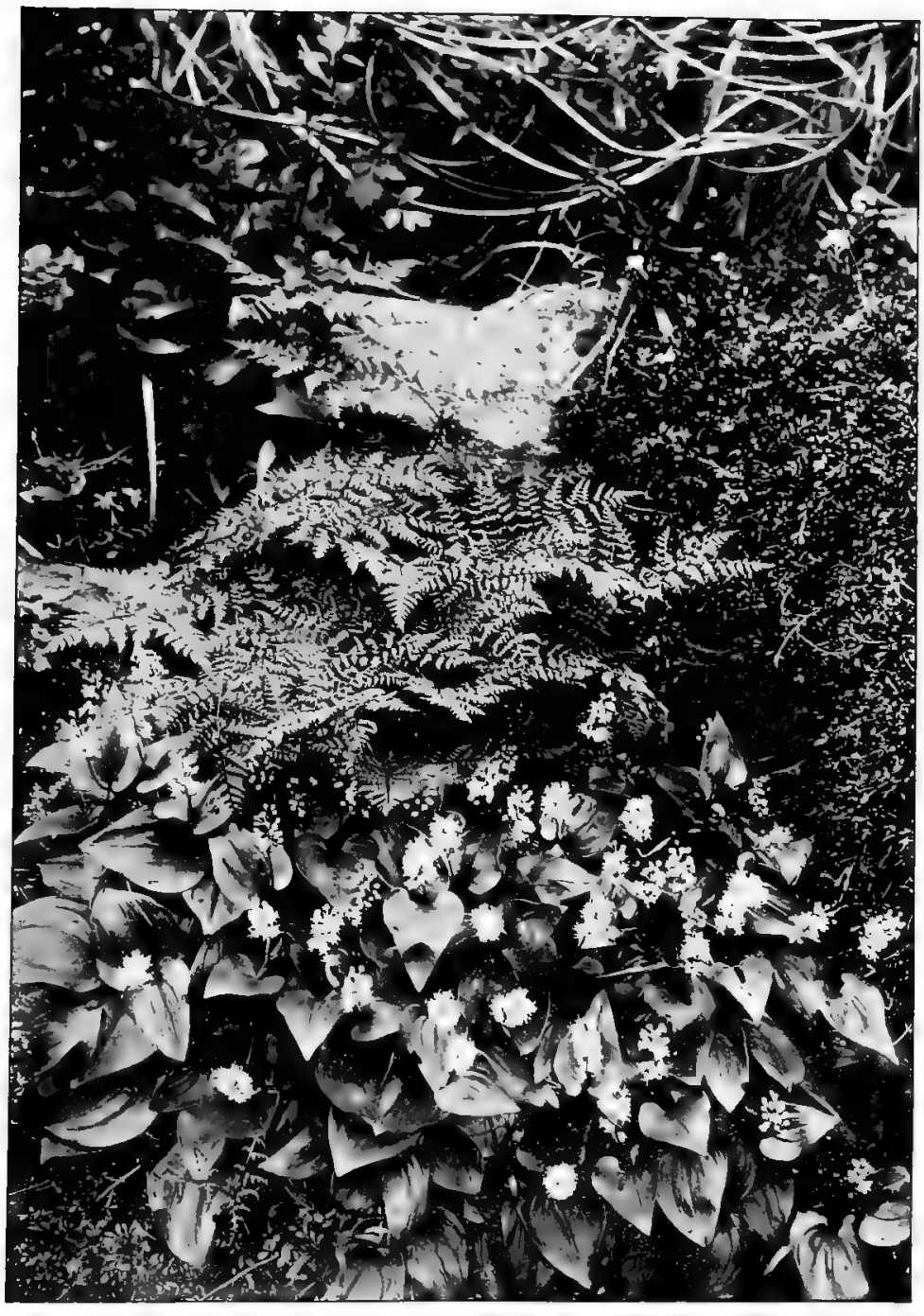

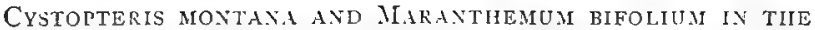
OLd GaRden. 

emerge in broad hay meadows, bending blue with huge old clumps and dense colonies of Gentiana asclepiadea. Here and there glows a belated golden globe of Trollius, abundant in its season as in the meadows of the High Force, or round the source of the Ribble under the northern end of Ingleborough. Ranunculus aconitifolius is here, too, and glorious Thalictrum aquilegifolium, and a broad stretch of Epipactis palustris, vaguely recalling a small and oddly leafy version of Ocontoglossum pulchellum, with pretty flowers of rose and white. Of other Marsh Orchises there are our handsome natives, mascula and maculata, both loving rich soil, damp rather than dry, and both quite easy to establish, if only you take the bulbs in autumn, being careful not to break the clod in which you dig them up. Both these luxuriate in the water-meadows of Swiss streams, and in size of spike almost recall their big brother, Orchis foliosa, from Madeira, a gigantic maculata, with dense, six-inch spears of purplish blossom, which is perfectly hardy and easy in rich damp soil, in a fairly sheltered, well-drained situation. Orchis militaris, with its near relations, Simia and Sambucina, are very handsome plants of similar persuasion, but dislike excessive damp, rare species from meadows in Southern England. Another pretty native, Morio, is hardly distinct enough for admittance to the garden; ustulata is quaint and inconspicuous; as for the gigantic, monstrous Lizard Orchis, with its vast-tailed, stinking flowers of greenish tone, this plant, so rare that there are perhaps only two specimens or so still lurking in Kent and the South, is a kind that craves for hot, dry, chalky soil and baking summer heat. But Orchis laxiflora is a brilliant, loose-spiked cousin of Mascula, hardly less rare than Orchis hircina, an alien immigrant upon ballast-hills at Hartlepool (and perhaps native, like so many rarities, to the Channel Islands), which is pleased 
with damp soil in a sheltered corner, though it is not more delightful than our own native, Habenaria conopsea, with long, thin, pink spikes of delicious fragrance. I cannot say as much for a notable American Cypripedium, second of its race for damp, rich treatment.

For with Cypripedeum acaule I have never been able to do anything at all. This dwarf species, with two leaves, and then a vast, bellying, pink pouch, folded double in the middle, is, I believe, the most southerly of the hardy Slippers, both in latitude and situation. For it frequents woods in the United States, and though Mr. Smith of Newry seems to grow it quite happily, with me it has never proved really winter-hard, though I have tried every possible soil and situation for it. A cold dry winter would probably please it a great deal better than our muggy, wet ones. Anyhow, in whatever light, warm, sandy stuff I put it, Cypripedium acaule, after flowering, goes home to mother earth in the normal course, but never comes back again.

Even more limited has been my experience with Cypripedium guttatum, a rare and most beautiful species from high dank woods all over Asia, through Siberia to Japan. I have never collected it, but apparently it haunts the mountain forests in the very thickest darkness of the pines, where it enjoys the black, cool humus of incalculable ages. The flower is small and rather hoody in outline, but wonderfully dappled with crimson and purple on a white ground. I have tried the plant only once, and then with little success. And it is by no means easy to get hold of unless one can manage to collect it for oneself.

The lesser American Cypripediums, candidum, parviflorum, and pubescens, are all easy doers and pretty species, growing as much as two feet high, with numerous flowers that, in pubescens and parviflorum, have yellow slippers- 
very like those of Calceolus, which, indeed, they replace in the New World-while parviflorum has the most fascinating, pure white pouches, that look like birds' eggs. I have found all these perfectly thrifty in any cool, rather rich, light soil, such as the Cypripediums love-though I am not sure that they are particularly long-lived. Cypripedium arietinum is a rare North American whom I only flowered once, a very curious, attractive creature with a blunt-nosed pouch which, with the waved petals, gives the plant its titular resemblance to a ram's head. This throve for a while in similar ground to that which suited the other compatriots; though now, I fear, it has returned to its long home.

I have little love for Adenostyles alpina, with its large triangular colt's-foot leaves, white on the reverse, and its big flat heads of pinkish fluff. But this now abounds by our Alpine stream, as we climb towards its upper glades. And so it goes, through beds of buttercup and many another casual golden beauty, till we leave the last pine woods, and begin to mount over open ground, stony and loose, in which the stream is diffused, and nourishes in the damp débris Saxifraga aeizoeides, Campanula pusilla, Campanula Scheuchzeri. On the ruins of a little shelter you will see thick plumy tufts of Cystopteris alpina, kindly and adaptable to a cool corner of the rock-work, and the occupant, by some unguessable chance, of one churchyard wall in Southern England.

Now we are over the ridge and nearing the last plain before we accompany our stream up and up to its source in the moraine and the unsleeping snows. In a narrow channel it flows, no longer a stream but a streamlet. Above its banks on one side hang loose curtains of Primula viscosa from shady rocks; on the other, a sunny bank of grass is blue with the trumpets of Gentiana acaulis. Down by the very water-side are hurrying 
blooms of Soldanella alpina, which show that the snow has only lately been melted from that deep gully, and the roseate heads of Primula farinosa tell the same tale. Then suddenly, as we climb, a splashing violence of blue assails our eyes. It is the first tuft of Gentiana bavarica, not to desert us now until we reach the final wastes of stone and the realm of its cousin brachyphylla.

No colour that I know can touch that of the Bavarian Gentian as you see it among the lush emerald grasses of the mountain marshes-a blue, thanks to itself and its setting, of the most pungent solid sapphire, rich and dense. Gentiana bavarica is always beautiful; but I think I never saw it lovelier than one day in late autumn on the Brienzer Rothhorn. I had misguidedly made the ascent of that hackneyed peak to see if by any chance I could hap on Ranunculus rutaefolius, which is reported from the slopes towards Sarnen. Early snows were already descending, and the nights were hard with frost. All day I toiled and caught nothing, slithering perilously about on the glazed, rotten rocks of the northern cliffs, after various alluring-looking buttercups, that always turned out to be ordinary alpestris. So I gave up the struggle and began to stroll down from the peak. October had sent all the plants to their rest, and nothing brilliant was to be seen. The air, too, was clear and cold with the nip of autumn, filled with the indefinable oppressive anguish of the world's yearly death. Far already on her downward journey was Our Lady Persephone, carrying the flowers with Her to the underworld; and the frozen breath of Hades floated up through the Gates of Death thrown wide for Her coming. And then, in a little hollow, dank with molten snow-water, browned and rotten with frost, I came upon a blooming crowd of Bavarian Gentians. Their poor, brave flowers were halfcongealed, half-melted with soaking damp and frost, yet 
still they flaunted their splendour unconquered, and made that small wet dell a brilliant basin of blue. Alas! I would that such persistence, such generosity, would mark Gentiana bavarica in England. Give it the choicest place in your choicest bog, nurse it up with silver sand and finest mixtures. But it will seldom be permanent. Perhaps we cannot give it rigours enough of climate-not sufficient sternness at one moment of the year, and enough continuous encouragement at the other.

Now the stream has reached the plainland of the last huts, the summer station of the cattle and their keepers. Here is a little meadow, perfectly flat and smiling, through which runs a placid brook as through many an English lowland. Its banks are dense with common nettle and blue Monkshood, thanks to the corrupting occupancy of man, who, wherever he may go across the world, takes with him all his weeds-moral, no less than vegetable, to thrive abominably and wax gross in virgin soil. Beyond the wooden huts lies a colony of boulders by the waterside, fallen from the slope above, which rises starkly overhead towards the moraine. On these huge rocks are found earnests of the promise above us-Senecio Doronicum, Primulas, a few stray plants of Asplenium septentrionale and Lloydia serotina. These are both natives, but rarissimi, of North Wales. The fern is a strange, wee thing, linear-leaved, forked like a serpent's tongue; the Spider's-wort, from its tiny bulb, emits a few threadlike leaves and then a dull white blossom like a star. I quested for it once among the dark rocks in the Devil's Kitchen above Llyn Idwal. No place has ever so daunted me; on all sides black, awful precipices dropped towards a black, unsmiling little lake far down at their heart; clouds, gloom, and storm made the inhabitants of that dreadful world. Timidly and abjectly I hunted the Lloydia, frail pale Princess of so grim a keep. The 
Devil's Kitchen is a black cañon opening, high above the lake, into the flank of the Glydyrs. Its sides are dank and inaccessible, narrowed like the Symplegades, wrapped eternally in a damp and rayless twilight. Here, on ledges of these adamantine walls, linger rare specimens of the Spider-wort. But, though I searched long, I could see nothing-nor, if I had, could I have climbed up to reach it. And now that, after many years, I have found and collected and grown the Lloydia, I chillily announce that, except for sentiment's sake, it is not worth the collecting or the growing.

Now we have done with the plainland. The stream brawls down upon us over a slope like a wall, and we have to breast an incline so steep that our knees are against the opposing earth at every step. At first we climb past stunted masses of Gentiana nivalis, dazzling in their light, clear ferocity of tiny azure stars; over great rosy flowers of Trifolium alpinum, and amid the nodding golden suns of Arnica montana; over the loose trails of Veronica saxatilis, brilliant with its short-lived blue blossoms, large and intense in colour, with a ring of crimson at the base. Easiest and most thriving of Veronicas is this, easy in every way, and a profuse, faithful seeder, my favourite, almost, in its large but not very interesting race. It occurs, rarely, on the Scottish mountains, and very rarely indeed in its rose-coloured form, fruticulosa. Kirki, guthrieana, and satureioeides are of the same nature, though guthrieana is paler and more bushy; repens forms a close mat of glossy leafage, hidden from sight in summer by a myriad pale flowers, large and softly blue; prostrata and rupestris are rampant, mat- and curtain-forming Alpines, invaluable for the rock-garden, developing sheets of azure in their time; filifolia grows erect into a filmy fuzz of fine greenery, starred with china-blue blossoms; bellidioeides is simply pale and 
dowdy; Allioni is simply dark and dowdy, despite its great rarity, which leads one to expect marvels from its dense, close carpet of branches, clothed with rounded leaves in pairs. Alpina is the bitterest disappointment. The name ought to be a guarantee of worth; but Veronica alpina is pallid and minute of blossom, totally without value; as for balcana, which I had from Servian seed, it proved a little weed like our own arvensis. Last, but not least, comes the native Speedwell, dear attractive thing, to be allowed its full way in the garden wherever possible, and no more vigorous and easy than all its vigorous, easy clan-excepting only such capricious uglies as bellidioeides and alpina.

Arnica has been left behind by now, and the billside is one soaking sponge of bog. Here and there, on stalwart spikes, rise the large lurid goblets of Gentiana purpurea, huddled in a head, and ranging in colour through shades of dull yellow, brown, and livid bronze. Then comes something exquisite beyond all hope-something that clothes the wettest moss of the slope in tenderest, softest, warmest rose-purple. As we get nearer, straining our hearts to be upon this unexpected delight, we gradually discern its flowers to be borne in round, fluffy heads. What it may be we have no notion. Now it is at our feet; we plunge, lay violent hands upon it, possess it eagerly, with fondlings. And it is a garlic! And it stinks unutterably-and not all the multitudinous seas can wash us clean of that clinging stench. As a matter of fact, this is the common Chives of our kitchell-gardens, Allium schoenoprason, native of wet highlands in our own Lake Country no less than of the Alps, and, as another matter of fact, a remarkably pretty thing, well worthy of admission to any choice territory and marsh, were it not for its unutterable odour. And here I will not deal exhaustively with possible garlics for the rock-garden, 
except to say that pretty, scentless, white neapolitanum is hardy, that blue kansuense, rosy, big-flowered ostrowskyanum, pretty, pink pulchellum, wee hierochunticum are all attractive and often inoffensive; common yellow Moly is good for a rough, dryish bank, unworthy of choicer stuff. Erdelii is a large, hideous novelty, with globes of dullest grey-white; Schuberti is an immense, weird creature, with huge, round, bomb-like heads'of pink, projecting more flowers on longer stems all over the ball, in the wildest and most Struewel-Peter manner. Triquetrum, again, is pretty, of a dead, dull white, looking like the ghost of a dead white bluebell, sodden in water. This fills every vineyard in Liguria, and is a great rarity in the neighbourhood of Bristol.

And so we shake off the malodorous memory of the Garlics and go forward, topping the slope, and finding ourselves at last in the upmost levels. Now the stream flows gently, between banks that are clothed with the rosy snow of Silene acaulis, so dense with flower that each yard-wide plant seems a mere mat of colour. Silene acaulis has a vast woody taproot, impossible of collection, but comes well from seed, and grows well, too, in any open, well-drained place on the rock-work. But in cultivation it never flowers with anything approaching its proper generosity. Perhaps the moraine-garden may cause it to wake up. Exscapa is a form differing only in the fact that the flowers have minute stems instead of sitting flat on the cushion, and saxatilis, as far as I can see, is indistinguishable. Silene rupestris is a pretty whiteflowered biennial for dryish places; Silene alpestris, despite its name, is a bog-plant of the very highest rank, loving any fairly moist corner, and running riot in a mass of narrow, glossy leaves, sending up, on stems of about a foot, abundant loose showers of white flowers, circular, and delicately notched all round. It seeds, too, in pro- 
fusion, and blooms far on into autumn-an altogether indispensable delight. Silene pusilla is a most exquisite thing, a miniature of rupestris, identical in all respects but reduced to the most diminutive proportions. I doubt if it has quite the robust constitution of its big sister; in any case it should have a very choice corner of the bogif only on account of its minute loveliness. Silene saxifraga is a spidery-growing rock-plant, interesting, but not brilliant, with creamy flowers, brownish on the outside.

Most brilliant of the race is Silene Elizabethae, from hot moraine-slopes of Northern Italy, dwarf, stickyleaved, with immense flowers like those of a Clarkia, which produce-at least they have produced with meabundance of sound and fertile seed. This plant loves the moraine-garden, or a warm, well-drained slope in light soil; as for the slugs, they adore it as an article of diet. Silene Pumilio is similar, but smaller-a difficult thing, I have always found it, craving something which I could not supply, though I have tried peat and granite and silver sand and everything that seemed at all likely. At last, however, some pot-plants in sharp, light loam are thriving well. Silene virginica, from hot Virginia, is gorgeous, with huge scarlet flowers, but I have no hopes of ever succeeding with so miffy a Southerner; another tall Silene is Zawadskyii, which makes promisinglooking rosettes of glossy green foliage (like Primula clusiana), and then sends up stems of dull, disappointing flowers. Remains only Silene Schaftae, a useful dwarf border-plant, with abundance of magenta-rose flowers through late summer and autumn. Asterias is an annual, so is compacta-big, brilliant things, greyish, glaucousleaved with spreading heads of big red flowers; beautiful dwarf palaestina, with abundance of soft rosy flowers, is painfully half-hardy. As a rule, to tell truth, all pink 
Silenes, except palasstina, have too much chalk and magenta in their tones ever to please me. My prime favourite is the white-starred, dainty alpestris.

Meanwhile, as we mount by the stream, over ribbed rocks, and gradually thinning herbage, the beauties of the upmost levels throng thick. These are the very

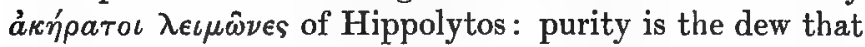
waters them, and the high Gods walk here, for all who choose to see. Against the grey stone shine in contrast the gold-and-violet suns of Aster alpinus amid the silver stars of Edelweiss. Like a dingy caricature of the Aster appears Erigeron alpinus, and the grass is dotted with the deep, brown-crimson spikelets of Nigritella angustifolia, delicious little Orchis, which is filled with the most rich and penetrating fragrance of Vanilla. This, though I have oft collected it, I have never been able, worse luck, to get established. Down by the bed of the stream itself are the children of the bog. Saxifraga aeizoeides and the two Campanulas have been left far below, and their place is filled by the blues of Gentiana bavarica; the lighter, clearer colour of Myosotis rupicola; the startling whiteness, against glossy green, of Ranunculus alpestris, growing every minute more abundant; and the soft lilac of Soldanella with the rosy pinks of Primula farinosa. All these, of course, are for moist or marshy corners of your bog, with the exception of Myosotis alpestris and its variety, rupicola, which endure far heavier damp on the well-drained Alps than ever they will in cultivation; where, on the contrary, though alpestris is an easy border plant, the much more lovely, delicate, and capricious rupicola requires very perfect drainage and protection from excessive moisture if you are to make it a sound perennial. For the bog, however, you may, of course, use cautiously our own brilliant native palustris, in some of its newer improved varieties, which never look better 
than when on the edge of water, or luxuriating in the wettest bog. But cautiously, say I; for Myosotis palustris is a rampant greedy grower, and pairs better with other such stout creatures as Mimulus.

Of Primula and Ranunculus your bog may be proud. All the Alpine Buttercups, alpestris, rutaefolius, kernerianus, gelidus, glacialis, Traunfellneri, Seguieri, crenatus, bilobus, will thank you for rich, deep, wet soil, in which they will thrive like potatoes. Nothing is more effective in a garden than a damp, stone-strewn tract all dotted with the glossy little bushes and the big whiteand-gold cups of Ranunculus alpestris. Indeed, all these high-Alpine Buttercups will thrive in almost any good cool corner, provided their soil be heavy and their conditions not too arid. Rarest and loveliest is a treasure from the Austrian Alps, which I have only just succeeded in procuring, after years of craving. This is Ranunculus anemonoeides-the true anemonoeides, not the pretty little Thatictrum anemonoeides with large white flowers on short frail stems, which is sometimes confused with the Ranunculus and offered in catalogues under the auguster name. The Ranunculus inhabits much the same wet shingles in the higher eastern ranges that delight glacialis in the western moraines. It has clawed, divided, fleshy leaves, glaucous and beautiful ; and immense flowers, like those of a mountain Chrysanthemum, pearly white, verging to a delicate sunset pink. From what I have seen I make no doubt this wonderful beauty will prove as easy as the rest of the group, and perhaps the finest of them all.

I have already so far chanted the Litany of Primula that I can add little to my song of their praise. But first, in justice, I must pause to adore my novelties in the race-abhorrent from bog-treatment though they be. Now, while Auricula Golden Queen has huge obese round, 
amber flowers, I have realised, this year, the superior grace and beauty of two Auricula-forms, similis and Obristii, with long trumpets of a lovely rich yellow. And bellunensis is even richer in tone, of a yellow deepening towards orange-magnificent; then among Viscosas comes the new apennina, a gem of gems, very rare and untried. But this is a fine thriver, nobly floriferous, with round heads, on dwarf stems, of very large, round, overlapping flowers, gently pink, with a dim white eye-more beautiful than even Cottia at its best. And then, again, I have just flowered a new cousin of viscosa collected by a neighbour, and quite the most gorgeous of its kind, conquering the finest Viscosas, Ciliatas, and Helveticas; this is a robust grower and very free, sending up stems of four or six inches, crowned with a domed cluster of large flowers -deep, dazzling purple, with a sharply defined white eye. So far as I know, quite imperfectly, the tangled race of Primula, this beauty has no name, and deserves a good one. And now I will go on to say that rosea is the loveliest thing for the bog that heart of man can desire, growing in dense old tufts, with their feet in running water-but it will do as well in damp ordinary soil-with those matchless carmine flowers in very early summer. Then comes pale snowy involucrata, sweet and holy little plant, with glossy rounded leaves, and gracious upshooting stems, another glory of the bog or damp rock-work; Parryi, large, deep purple, splendid; Deorum, with smaller but no less handsome flowers (my plants have now taken to flowering freely-but in spring, not in late summer, as their native habit is); japonica, stalwart and coarse, best fitted for the copse and rough outlying stretches; new, gorgeous little biennial cockburninana, with flowers of ardent orange; Stuarti, if you can get it, another giant species, with great heads of purple; farinosa, of course, with its big brother longiflora, and 
its wee brother, scotica - not to mention its other relatives, magellanica, halkusanensis, algida; sikkimensis, tall and royal, powdery-white, with swaying peals of sulphuryellow bells; and glutinosa with queer crowded little bunches of blue-violet flowers, which it can only be induced to put forth when grown in the mossiest, spongiest bog. Finally there are the giants of the denticulata and cashmeriana kinds - fat cabbages for outlying shady banks, and the new pulverulenta form of japonica, with its offspring, the flaming hybrid Unique, whose other parent is cockburniana, and his constitution poor.

Then there are the North American cousins of Primula - the Shooting Stars, which love rich, well-drained, damp soil. Who the Twelve Gods may be, and what claim they may have to Dodecatheon I cannot tell, but these flowers of the Twelve Gods are gracious if not dazzling creatures, large leaved, with tall stems that carry a head of little purplish, gold-pointed flowers like small Cyclamens. Their colour is not very interesting, and their growth a trifle gawky; Meadia is the largest, and has better-coloured varieties; pauciflorum is quite the best kind, a free seeder, smaller than Meadia and excellent for the bog, a most attractive fair frail beauty.

But the rarest species of all-and indeed the only Alpine species that the twelve undiscerning gods possess, is Dodecatheon integrifolium. This, however, is a rare, difficult little plant, an Alpine of Alpines, requiring a very choice open space in the bog, with abundance of stone chips and fine peaty humus. It only grows three or four inches high, with three or four flowers in a loose cluster at the top of the stem. The blossoms, hardly smaller than those of great stout jeffreyamum and Meadia, look very large for the minute daintiness of the plant; and their colour, though running, like so many tones in this race, towards a magenta-purple, yet have so 
much depth and fire, so bright an orange at the flower's eye, that the little clustered cyclamens at the crown of that frail stem have a strong charm-especially if you collect this Dodecatheon in its native haunts. I came upon it high in the Canadian Rockies, near the last limit of herbage. All around the stones were triumphing over the vegetation; above, in a vast amphitheatre, were walls, screes, escarpments of naked rock, falling, in terrific arid precipices, or long slopes of débris, towards a green icy lake a thousand feet lower down. And here, nodding amid the rare, sickly grasses, waved the ardent, fewflowered clusters of the Dodecatheon, and, as I gathered up its roots, a striped squirrel-who must have been one of the Twelve Gods in avatar-came and sat on a stone and chittered angrily at me for removing his treasures. But alas! in cultivation, I have never succeeded in doing anything with Dodecatheon integrifolium, though one would have thought my soil and climate sufficiently Alpine, sufficiently reminiscent of its own.

Yet another large cousin of the Primulas there is, which is good for a sheltered rich corner, not too select, on the outskirts of the bog. This is Cortusa Matthioli, whose variety grandiflora is better than the type and better than the other species of Cortusa. These Cortusas throw up each year large, bristly, soft green leaves, like shaggy versions of the Wood-sanicle, or Primula sinensis, and then, on a tall stem of about a foot, clusters of pendent Primula stars, which are of a dark and brownish red. They are interesting rather than brilliant, but are well worthy of a place if you have room. 


\section{CHA P'TER XII

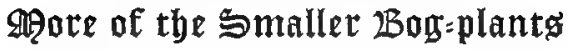

IN this long interval, while we have been pursuing our stream without comment, we have mounted past the limits of the grass, over a final tract of Ranunculus pyrenaeus, and are wandering amid the soaking shingle, where the river is born, and lies hidden at his source like Iamos, in beds of blossom. And this is Ranunculus glacialis, whose snowy, great cups glitter everywhere above the wet and glistening stones. Beyond there is nothing more, except, perhaps, one golden flare, amid the greyness, of Geum reptans. All around are Androsace glacialis, Campanula cenisia, Viola cenisia, Gentiana brachyphylla, Chysanthemum alpinum, Myosotis rupicola, Papaver alpinum, Iberidella, Ranunculus alpestris, the ugly little forms of Saxifraga varians, Saxifraga Androsacea, and Saxifraga biflora. But of these only the Saxifraga varieties, the Androsace, the Ranunculus and the Chrysanthemum, inhabit the wettest places; and in cultivation wet is fatal for both the Androsace and the Saxifrage. Chrysanthemum alpinum is a pretty little creature, though, and very fairly easy to establish in the shingle of the bog or the moraine-garden. It has camomilish leaves, quite bright and glossy green, with impressive snow-white flowers, golden-eyed, and exactly like those of its big cousin, Chysanthemum leucanthemum, of every English hayfield, though a little smaller than the 
Ox-eye, and carried on stems about three or four inches from the ground. Lapponicum and nipponicum are very close cousins, even if not actually brother-forms of the same Alpine and high-Arctic species. Chrysanthemum Zawadskyi is another bog-plant of easy culture-rather taller than alpinum, rising to five or six inches, with ferny foliage and stocky, stolid flowers, whose white is tinged with soft pink. As for Chrysanthemum Tchihatchewi, this must go far, far from the bog, a ramping, ferny carpeter, making wide mats over the driest, rubbliest places. Its beauty is its foliage, its recommendation its violently robust habit, and its love of hopeless, worthless, dry places where nothing else will grow; its flowers, on five-inch stems, are rather small dull daisies, white, with greenish-yellow eyes. Most august of the family, of course, is Chrysanthemum indicum, the parent of a priceless garden race; but Chrysanthemum indicum has no other claim to a place, for it is a tall, leafy, gawky weed, with heads of minute, uninteresting flowers.

For the very choicest corners of the bog, in fine, damp shingle, very rough and fiercely drained, should go some of the marsh Saxifrages-our own rare Hirculus, in its variety major; its Arctic cousin flagellaris-if you can get hold of it; androsacea, if you think its small flowers of dullish milk-white are worth the trouble. Stellaris is so easy that you can put it in any very wet place; so is rotundifolia from the woods below; biflora, on the other hand, lovely frail trailer with its great crimson-purple flowers, this, although luxuriating in the wet grey glacier-mud when at home, is more difficult to please when out on a visit-alas! as a rule, not sojourning long in one stay despite the best attention. It requires very careful treatment in the cool, well-drained rock-work. As for aeizoeides, this is quite a rampant grower, and may 


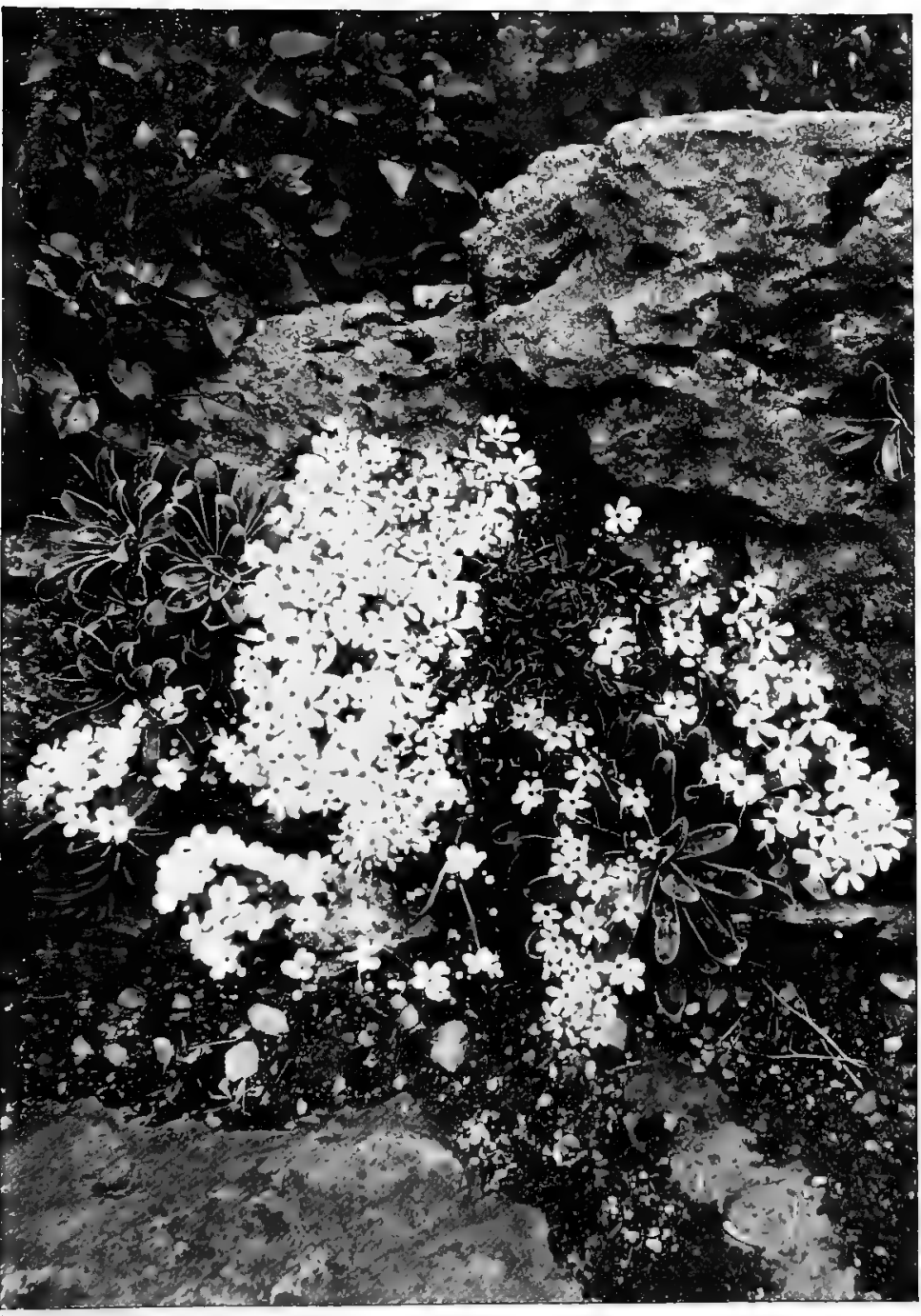

Saxifraga lingulata on a rock in the Oli Garden. 

be put in any marish place, not too choice. Cymbalaria, brilliant little annual, thrives and seeds abundantly in every dampish corner or flat, making, if you choose, a dainty golden contrast with the pale pale purple cruciform stars of Ionopsidium acaule, similar in size, habit, requirements, easiness, daintiness, and charm. These, when established, will seed themselves independently from year to year, and need no more care than the occasional scattering of a little fresh seed. And, for dank rocks near the bog or overhanging, you have Saxifraga Geum, umbrosa, mutata if you love beauty and curiosities; pennsylvanica, hieracifolia, and erosa if you desire coarse and stalwart uglies. On dank, shady ledges, too, thrives riotously one of the queenliest of all Saxifrages-my wellbeloved lingulata, with long, loose plumes of snow, which I am now establishing in the cliff above the Lake at Ingleborough, in places exactly similar to those damp shelves, from which I collected profuse mats of it near St. Martin Lantosque. The hypnoeides group, too, will be happy on rocks in the neighbourhood of moisture, while one of them, splendid aquatica, will prosper even in the bog itself, though, being large and stout, it must be cautiously introduced-and alas, that none of the Burseriana group will tolerate the bog! Nevertheless, in this section, I must pause again to congratulate myself on some beautiful novelties. Who Paulina may have been-unless it was Lollia of that ilk, who ran, so disastrously for herself, against the Augusta Agrippina in the great matrimonial stakes for the hand of the Emperor Claudius-I have no notion. 'No matter, no matter, if I can get at her, I doubt if her mother will know her again "-so bitterly do I envy and grudge her monopoly of a most rare, lovely little new Saxifrage, which challenges Gloria, and extinguishes Boydi and even beautiful Faldonside. Saxifraga Paulinae, from some- 
where in Italy, is a thrifty, vigorous little plant, tufted, spiny, silvery as Boydi, but evidently more vigorous and solid. The flowers, too, are larger than those of Boydi, freely borne, and of a pure, exquisite, lemon yellow. So far Paulinae is very rare and very wee; when it has grown larger I can foresee it will claim high royal rank among its kin. Another novelty is pretty Petrarchae, also an Italian-like rochelliana in flower, and like Boydi in growth. Obristii has not flowered yet, nor has the hybrid jaeggeana, but Obristii is clearly a cousin of coriophylla. Corymbosa is simply luteo-viridis, dalmatica is a twin to aretioeides, and beautiful Burnati is worthy of his parents-aeizöon and cochlearis.

The sad tale of Gentiana bavarica has been told already ; and the same sad tale lies against pyrenaica, imbricata, and rare little pumila, with four cleft flowers of sombre sapphire; and there are but few Gentians that will help to glorify the ordinary bog. Pneumonanthe will lift its deep blue trumpets on stiff wiry stems in the heathier, drier corners; arvernensis, being the same plant, but magnified, will do likewise in the same conditions; septemfida cordifolia, prostrate, with its clusters of immense blue blossoms, will flop happily about on a damp, well-drained ledge, in any light, rich soil; verna and acaulis, in really dry and torrid districts, find their only chance of life in the bog, though in nature, and with me, in my Alpine air, they would both abhor it and refuse to grow; and the glory of asclepiadea has received its due place in the larger bog-garden.

Nor have the Gentians many relatives adapted for the marsh; the one noticeable branch of cousins are the Swertias. And these are poor relations indeed. The essential splendour of the Gentians, of course, is their blue; and the Swertias, on leafy stems about a foot high, carry loose spikes of starry flowers which are of 
the dullest speckled slate-colour imaginable. The type of their whole race is the common Swertia perennis; all the others are hardly distinguishable, and the sole recommendation of the family is the absolute ease with which any and all of them will prosper in even the wettest parts of the bog.

I know no Erythraea for the bog; those bright heads of clear pink Gentians are specially adapted for embellishing the bare, dry downs of southern England; culture, as a rule, they resent. Cicendia, or Gentiana, pusilla I have collected in Swiss bogs, and vainly sought on Dorset moors, following that ominous trail of Mrs. Yeobright and ill-starred, tragic Eustacia. This Cicendia, very delicate and frail, is hardly a plant for the garden, if ever it could be induced to grow there. Nor are the Campanulas of any great note for the choice, high-Alpine bog. The moraine is their pet nursery; Scheuchzeri, however, thrives in wet marsh, pusilla is tolerant, and our own dainty little hederacea is the sweetest of bog-trailers, with wee bells of pale blue on invisible, thread-like stems. This, however, is hard to establish, and must, I think, have tough, coarse grasses to ramble through and seek cover in before it can be made truly and permanently happy. Few things can be lovelier than the mixture of this delicate, gentle azure, with the delicate, gentle fleshpink of Anagallis tenella, another wee native marsh-plant, which by a happy touch of nature is often found with the Campanula in wet places of the West. The Bogpimpernel, near cousin of the Primulas, is an absolutely prostrate thing, creeping about with branches of glossy little round green leaves arranged in pairs. In due time, in summer, these are hidden from sight by a profusion of stemless flowers, large, starry, of an exquisite shade of pale rose. I have seen the Anagallis on Surrey heaths; I have seen it on a wet rock in the Lakes, where Ruskin 
used to go and worship it; and never does the almost exotic charm of the plant evaporate; it is so profuse and so lovable in blossom that one can hardly, somehow, believe a thing thus richly dainty to be a native of our well-trodden, humdrum land. And, with the blue of Campanula hederacea, the Pimpernel becomes loveliness made more lovely. Nature, when she turns her mind to the matter, is indeed a cunning artist, and arranges many a picture of bewildering beauty. Have you ever seen the orange of Arnica blending, on a high, rough mountainside, with the violet daisies of Aster alpinus and the great shaggy bells of Campanula barbata, soft and pale in their delicate china-blue? Or the violent sapphire of Gentiana bavarica grading with the gentle azure of Myosotis rupicola against the ardent matted rose of Androsace glacialis, with the snow-and-gold of Ranunculus alpestris to complete the harmony? Or, for a subtler effect, a meadow crowded with the celestial stars of Gentiana verna, amid the innumerable lilacs, mauves, purples, tyrian darknesses of a hundred million mountain pansies?

The most subtle picture, though, that I ever saw, lies far back in my memory of the Alps. I was descending through a golden sunset, from Beatenberg to noisome, clamorous Interlaken. The evening was clear, calm, and radiant; the town lay very far below us, unseen, unguessed, unguessable amid the benign tranquillity of the hills. And suddenly we came out into a marshy clearing of the woodland, falling away steeply down towards the sunset. And the whole slope, against the fiery light of the West, was thick with the soft rose of Primula farinosa, abundant as sands of the sea, and among it everywhere stood the livid, purple spikes of Bartsia alpina, incandescent and amethystine in the red glow. Now the Alpine Bartsia, with dull, labiate flowers, is coloured, bracts and leaves and all, with a most 


\section{MORE OF THE SMALLER BOG-PLANTS 243}

wonderful sad deep shade of plum-colour, which, by itself, is haunting and subtle enough in all conscience, without any sickliness or indefiniteness of tone. But the colour of the Primula, rich and dainty pink, is of precisely the shade to fulfil and double the attraction of the other. And the two plants together in mass form a picture more perfectly satisfying, I verily believe, than any other floral harmony that I have ever seen-except perhaps that of delicate, butter-coloured Tulipa Batalini among the lavender stars of Anemone robinsoniana. Bartsia alpina is a rare native of our northern mountainbogs; you will meet it here and there in Westmoreland, round Malham Cove, and in all the streamlets of Upper Teesdale; I have never found it easy to establish, and have, at times, suspected it of some morbid tendency in the matter of its root-system, so delusively simple is it to collect and plant. Anyhow, for the bog-garden, it is a case like Mrs. Allen's vain longing for acquaintance'Despair of nothing that we would attain'; and, may I add, 'Unwearied diligence our point will gain.' But I think I had better say 'may,' with all due respect to the Divine Jane, and the edifying unknown authority-was it a copy-book?-from which she quotes.

Besides Anagallis and Bartsia, our own marshes give us some valuable things. For the common bog-Asphodel, Narthecium ossifragum-the 'Bone-breaker,' because its glow deludes you into sloughs where you break your legs -with its sturdy stout spikes of golden yellow, and its little swordlike growths of leafage, like a wee Iris, is good and very easy for any rougher corner in damp, heathy soil. Very much smaller, choicer, and less brilliant is Tofieldia palustris, a rarity which, like so many other rarities in England, makes one in the aristocratic band that turns Upper Teesdale into the Almack's of British plant-life. Tofieldia is like Narthecium in growth, but 
very much daintier, with only one or two growths, and a fluffy little spire of small pale-yellow flowers. Canaliculata, from the Alps, is rather bigger, and both are interesting for the bog, to combine with the rather similar pink and white spikes of their compatriot, Polygonum viviparum. As for our rare bog-Orchids, Liparis and Malaxis, let no one, I would urge, attempt them, or nurse hope of growing them. Dull little greenish things, they are no great loss; but the same sad advice applies to three royally beautiful marsh-Orchids from North America-Pogonia, Calopogon, and Arethusa-plants of the spongiest, wettest peat-bog, loving to grow in cushions of the living Sphagnum, like the Cranberry. The Cranberry itself, with flowers like wee crimson Cyclamens on thread-like stems, is very pretty and harmless for the bog; Andromeda polifolia is larger, with rosy bells of blossom, and no less easy.

Then there are our own native Pinguiculas, vulgaris, and the very rare white-flowered alpina, for the same facile culture as I have already described for grandiflora. But lusitanica and bizarre vallisneriaefolia are too difficult for any ordinary garden. Sisyrinchium anceps is an attractive little plant, native to one patch of ground in western Ireland, and delightfully free and happy in the bog - a small bulbous thing, cousin to all the Amaryllids, with grassy foliage, and big stars of brightblue that break from the rush-like stems. This delights in wet ground, and seeds itself freely without effort; and altogether is a treasure. Even more glorious is the similar, larger bellum, for much the same, or drier treatment; and most glorious of all is grandiflorum from British Columbia, rush-like and very fine in growth, with thready, waving stems that break out in February and early March into immense wide pendent bells of an ardent silky sheen of violet. This lovely, lovely thing is 
perfectly comfortable in the garden, if only you give it a select corner in light peaty soil, in a position, for precaution's sake, where spring winds and rains may not too violently assault the delicate fabric of the flower. Sisyrinchium striatum, to warn my readers, is totally different; in growth big and coarse, like a German Iris, with crowded spikes of stupid little straw - coloured blooms. This likes an ordinary dryish border-and doesn't deserve it. Not unlike Sisyrinchium anceps, again, is the Blue Rush of Provence. Aphyllanthes monspeliensis is true to the name, forming a rushy tuft, indistinguishable from a Juncus, and then erupting into big open cups of soft clear blue. This delight, however, is not a bogplant. You will find it in the woods between Cannes and Grasse; in cultivation it likes a warm, sheltered corner in rich sandy peat, where it grows more beautiful every year.

To return to our native bog-plants; the Sundews, all very much alike, and all, therefore, to be treated of under Drosera rotundifolia, are pretty and interesting, though not brilliant. Evil little things they are, with their carnivorous habit. One wonders what crime the past lives of Drosera can have held, that now the race should be compelled to dree so ominous and unpleasant a weird of murder and fraud. When will the Sundews be free of the burden, through some self-sacrificing individual plant who shall starve to death rather than take life, and so redeem his race into the happier paths of peace and virtue? Not to pursue such high inquiries beyond what is fitting, I will merely add that the Sundews are not hard to establish in wet moss, and that their flower-spikes always promise much more than they perform, only one or two blooms opening at a time on the uncurling crozier, and never producing any fine unanimous effect of blossom. The exotic Droseras, such as beautiful, rosy- 
flowered filiformis, are too frail and delicate to prosper long in the rough and tumble of the garden.

Sedum villosum I have already mentioned. This is a dear pretty little creature, which nobody seems to know or to grow. It is, I expect, of biennial tendency, but seeds happily, and is charming for damp soil or rock in the bog-garden, a frail wee grower, making one or two spikes of fat little leaves, about two or three inches high, crowned, in June, with big Catherinewheel flowers of a soft waxy pale pink. The common Grass of Parnassus every one knows, on the contrary. Does every one grow it? I, for my part, have always found it less easy and more capricious than its much more beautiful brother, Parnassia fimbriata, which I collected years ago in the Rockies. This, though it thrives most robustly in rich damp soil, is able to thrive robustly almost everywhere; a better-tempered plant was never imported. It has taller stems than palustris, a much freer habit, larger, crowded clumps, and larger white flowers, with the eponymous fringe of fine white hairs between each petal at their base. The other Parnassias are almost identical with fimbriata and palustris, and therefore less worthy of culture than the supreme fimbriata; there is one, however, nubicola, I think, or perhaps caroliniana, which affects yellow or a yellowish shade for its flowers. This I have grown, failed with, and forgotten. I cannot have had much pleasure from it.

Of ferns and grasses our own woods and fells give us one or two valuable plants for the bog. Near by must be the Beech-fern, on a high bank of light, rich, rotten soil. And infinitely more beautiful than Polypodium phegopteris, with the rather arid dusty green of its fronds, Polypodium dryopteris must certainly claim our worship. Than the rich brilliant emerald of the Oak-fern's fronds, 
both young and mature, the garden holds no verdure more startling in its clean radiance of tone. And the outline of the fronds, plumed and opulently-lobed, on invisible, dark stems, is no less lovely than their colour. The Oak-fern, abundant in the Alpine woods, is to be found with us in the North as a rarity, but abundant where it occurs, jewelling some high damp bank of moss and rottenness with the refulgent green of its plumes. In cultivation it is very easy to establish in luxuriance in any rich, cool corner of the rock-work or slope of the bog, where sun will not parch it, nor winds wreak havoc among its brittle stalks. With me, indeed, in a cool Alpine district, it grows rampageously even in the open, exposed to the utmost ferocity of our pale northern sun; but in hotter, dryer places it will certainly be the better of moisture and shade and shelter. The third of our Polypodies, calcareum, a rare plant from the stony screes under Ingleborough, is only for dry torrid banks of loose stone, through which it loves to run. Its fronds have the dusty tone of phegopteris, and in design, while finer than the Beech, have not the rich loveliness of the Oak. It requires full sun and exposure. Last of damp-loving little ferns comes Cystopteris montana, never to be overpraised, which I have collected in the Alps, and which occurs rarely as a high-Alpine in Scotland. This is found in the dampest places under shady rocks, a most attractive thing, quite unlike fragilis and alpina, with broadly triangular fronds of very fine lacy foliage. This I find, is of the happiest, easiest culture in any rich, cool, shady corner.

Of the Filmy Ferns, Trichomanes and Hymenophyllum, the less said the better; they are as nearly impossible as any plants can be ; the Maiden-hair is not for every one, but in damp, westerly climates may easily be made a denizen, if not a weed, of dark moist corners and caverns 
in the rock-work. Lastraea thelypteris is a larger, rather uninteresting fern for the bog; Lastraea oreopteris is stiff and stark in its upright growth, from open, heathy banks on the fells. Lastraea rigida, if one could get it, has the attraction of extreme rarity, and still lurks undiscovered among the common Lady-ferns on the upper slopes of Ingleborough, whence it was first recorded. On the same slope occurs the Parsley Fern-a mere caricature of itself as it luxuriates on the slates and primary formations of the Welsh mountains. But though I have seen Allosorus crispus making stout bushes by the stream-sides that flow down to Llyn Idwal, I have had so uniformly disheartening an experience with this fern on my limy soil, that I will not give it any recommendation for the bog.

Finally comes the one grass that is really of prime value for the rock-garden and the bog (not mentioning Festuca varia, beautiful neat cushion of finest emerald fur, even in midwinter). Poa alpina is indistinguishable in growth from the tufts of any common grass that one rends up as a weed. But in its viviparous form the plant produces rich heavy masses of living baby plants, the whole blossom-head being a great tassel of plumy emerald touched with crimson. Beneath their load the frail stems bend earthward, and there in due time deposit their load, each sprouting bulblet producing a young plant. Poa alpina vizipara is quite common in the Alps, and occurs very rarely in the Highlands and in western Irelandnotably on one mountain overhanging the sea. In cultivation it is perfectly easy and robust, thriving in any rich, damp loam. Its only drawback is its very close resemblance, while out of flower, to its common cousins, which often causes Poa alpina to be weeded up, while the real weed next door is left untouched.

In dry clefts of every wall in the Ligurian vineyards 
lives a small Aroid, with arrow-shaped leaves of glossy green, and queer little chocolate blossoms, whose hood prolongs itself into an immense feeler. The whole effect of the flower is that of a mouse, with waving tail, diving down some hole. Indeed the resemblance of Arisarum proboscideum to the agitated hinder-end of an escaping mouse is almost ridiculous. But this little plant, native of such arid dry corners in so arid and dry a country, must needs be of the most difficult culture in a moist cool climate like mine? Will it be believed that by one of Nature's incalculable freaks, Arisarum proboscideum is not only one of the best plants I know, but grows quite beside itself in the most sopping parts of the bog; forming into great mats and beds of emerald arrows, among which the diving brown mice frisk and sport in the most exciting manuer, waving their tails in every direction. And though not showy, this freakish little weird plant stands very high in my affections, not only for its rare quaintness, as for its unparalleled, unhoped-for adaptability. I have it everywhere now, in a hundred wet, damp, or dry, shady corners, always in rich soil, and in every exposure. And always it does best of all in full sun in the wettest marsh, though hardly less glossy and triumphant on the rock-work under the shadow of great boulders, in stiff retentive ground.

Of the other Aroids I have little to say. Arisarum triphyllum from Japan will be handsome when I have succeeded in establishing it on good shady corners of the rock. It grows a foot high or more, with one or two very graceful three-cleft, claw-like leaves, and a longtailed flower like an exaggerated Arisarum. Larger still is Arum crinitum, my only Arum, a magnificent foliage plant for a very hot sheltered place in dry rich soil, growing four feet high and more in a dense clump, and emitting, in early summer, enormous flowers of a dense 
brown-purple, whose odour is so appalling that during their reign the garden is entirely unapproachable. Similar in name, Asarum now recalls itself to me; a low-growing race, forming mats of small, rounded, glossy leaves, with small brown bells of blossom huddling round the root. As may be imagined, the beauty of Asarum lies in its foliage; in Sieboldi the leaves are variegated and marbled in more than thirty varieties considered worthy of names by their Japanese admirers. This, with our own native, europaeum, is useful, if not startling, for a cool, out of the way, shady corner in the bog, or near it, but not prominent or choice.

Notable among minute shrubs for the peaty bog are Kalmia alpina, Rubus pedatus, Rubus arcticus, Cornus canadensis. But all these must have a drier corner. The glorious blue showers too of Mertensia elongata seem to be produced as freely and happily in the wet bog as anywhere else in the garden, so delightfully accommodating is this most blessed of introductions. Virginica requires more care, and a selecter, warmer spot, not near the small things; primuloeides would seem to be a bog-plant from very great elevations, but must still go from my pages with the verdict non-proven.

A pretty common annual, which looks after itself in cool shady places, not too choice, is Claytonia perfoliata, which, with its twin virginica, has almost established itself with us as a native. It has glossy, waxy rounded leaves, and delicate loose spikes of pearly stars. But all Americans are not so accommodating as this. Who is there that has not wailed over Viola pedata? Now Viola pedata is one of the loveliest little plants that has ever timidly set root in our gardens-a small Violet, with claw-like, ferny leaves, resembling those of some choice Pteris, though of a greyish, leathery green. The large flowers are beautifully built and balanced, very freely 
borne, of a gentle clear lavender in the type-form, with featherings and splashings of purple in the basal segments. In the variety bicolor, more advertised, though hardly more beautiful, all the lower part of the flower is of a dense, velvety, tyrian purple. But Viola pedata is a perennial grief to the gardener. Its invariable habit is to dwindle away. Truth to tell, it is only a mimp -though the loveliest mimp imaginable. All you can do is to give it very perfect, sharp drainage, in some very choice elevated corner of the bog-garden, in very light, nutritious soil. Even then there is no great hope of permanence. As a consolation in misfortune, I may mention that Viola pedata is one of the many plants that have undoubtedly a strange unaccountable intractability even in their own native country. In America, in the districts where it is commonest, where it grows by the thousand in open sandy places, gardeners who carefully transplant it to an exactly similar place in their own gardens not a hundred yards away find that it inevitably pines and dies in cultivation.

For our bog-garden-for dank shady rocks in its neighbourhood, rather-most desirable and most dainty, is another Viola of very different temper, the little twinflowered, golden-yellow Violet that you find luxuriating in damp, cool, stony places all Switzerland over, from the depths of the pine forest, to the stony barrens near the summit of the Gemmi. With shade of rock, rich, damp soil, you cannot go wrong with Viola biflora, the gem and pride of stony steps and hollows in the garden, though slugs and mice, I admit, annoy it as distractingly as its big cousin calcarata.

For wetter places of the bog you may perhaps use, very cautiously, in out of the way corners, our natives, Viola palustris and the rare stagnina variety of the common Dog-Violet. Viola stagnina is a dwarf form of canina, with large, creamy white flowers, and occurs 
infrequently in the rough, marshy meadows rising up to the high moors opposite Ingleborough. In cultivation one has to be very careful lest it show the coarse habit and the plebeian greed of the Dog-Violet.

To deal completely now with the race. I will own that for dry places in the garden I think no Violet (as distinct from Pansy-violas) beats our native hirta at its best-a stalwart clump, producing an extraordinary abundance of contemporary blossoms, very large, scentless, and of a rich clear blue. I do not think the leafy American cucullata approaches this, nor stricta, Rydbergi, Sorora, nor any other of the fancy Violets that my manager so piously cherishes. To my taste these are all weeds, variant on canina. Sorora has big blue flowers and a good deal of leafage; the same applies to Rydbergi and cucullata; striata is rank and very leafy, with abundance of small creamy-white flowers; and the blue Violets all have white varieties-except hirta, so far as I know. This almost certainly has one too, only nobody has troubled to discover it. The best I can find to say for these coarse rampageous Violets is that they will thrive anywhere and make unobtrusive masses in any cool, good soil. Hirta, on the other hand, is tidy and neat in growth, sparing of leaves, and loves well-drained, rather dry positions, in woodland or open ground.

The last Violet $I$ have to mention I call upon with lamentation. I have never been able to get hold of it, for all the enthusiasm it aroused in me. It was in the wood above the Temple-'Tomb of Iyesyasu Tokugawa at Nikko. Between the vast columnar trunks of those secular Cryptomerias the setting sun cast arrows of gold on the dappled green carpet of herbage round their feet. The trees themselves were fired to ruddy sanguine, great scarlet pillars of a huge cathedral. And here and there on the ground there shone a wonderful Violet, fired 
by the sunset to a blazing amethyst. It had the size, growth, and habit of dainty pedata, the same finely cleft foliage; its flower was large and stately, of a vivid lavender. And there, amid the budding lilies and the splashed gold and green of the vegetation that covered the bare earth, the Violet glowed fierce in the red light. And there, for all I know, it still glows. I cannot obtain it. I get seed of all Japanese Violets I can hear of, but not one of them ever turns out to be the Nikko Violet of my heart-not even the most likely-sounding ones, delphinifolia, gryptoceras, japonica. At least my seed of gryptoceras never geminated at all, so that, by the irony of life, I conclude that gryptoceras was very probably the Violet I wanted. ${ }^{1}$

As for the two gorgeous new Violas, gracilis and heterophylla, these are of the wild pansy cousinhood, loving high grassy mountain-sides. Fine-leaved gracilis hails from Greece, and has the most intensely purple flowers I know anywhere. Heterophylla is only less brilliant, and both thrive and multiply like bedding Pansies. And that quaint, most rare of oddities, tufted, mat-like Viola arborescens from Les Baumelles, is a cushion-violet, to be grown on hot, rubbly banks, if you can get hold of it-which you probably can't.

I have been very happy and successful with a quaintness for the Canadian Rockies, which I collected in wet spongy places of the woodland bog, and now have growing and seeding all over the shady side of my rock-work, swollen almost beyond recognition. Mitella pentandra sends up a few palmate, handsome little leaves, and then, in normal circumstances, a four-inch slender stem, carry-

1 No : at the very last moment before going to press, I have discovered the Violet of my long quest. It is $V$. pinnata : variety, chaero. phylloeides-rival, and probably conqueror, of all others. If pedata is Margaret of Angoulesme, surely pinnata must be Christine of Denmark and Milan. 
ing perhaps half a dozen flowers. These flowers are round, greenish, small, and quite dull until you look into them. And then you see that the circular bloom is deeply cut and fringed all round its edge, into the finest delicate lace-work imaginable. There is nothing solid, in fact, about the blossom, it is all a fringe to the central mass where the organs live. In cultivation it thrives profusely, grows more than a foot high, carries more than a dozen flowers, makes a conspicuous solid tuft of leaves, and sows itself copiously all over the place. Of inconspicuous beauties this is the keenest and quaintest that I know. More obvious than this is a valuable marshplant, Calla palustris, a rampant, running miniature of the common false Arum, Calla ethiopica. This riots about over marsh and mud-flat, asking nothing but stern repression, and eating you out of house and home in no time.

In dryer corners, under bigger things, you will, of course, have a welcome for Sanguinaria canadensis, with its round-lobed leaves, glaucous blue and bronze, and its snowy flowers like Ranunculus anemonoeides,-or perhaps it would be shorter to say 'like an Anemone' straight out. This is never a nuisance and always a joy. One only wishes it would increase quicker, so joyous are its foliage and white stars in early summer, in cool places or under deciduous trees. I have it in colonies, both canadensis and its improved major form-under my group of Magnolias, Kobus, Watsoni, stellata, and salicifolia. Then there are the Poppyworts and Jeffersonias, -coarse things, though brilliant, and reminiscent of the ordinary common Chelidonium, trebled in size. More beautiful is the rare Eomecon chionantha, from midChina. But this exotic white Poppy for choice places, rich and warm, is not of unquestioned hardiness, and I have never been able to make a permanent success of it. 


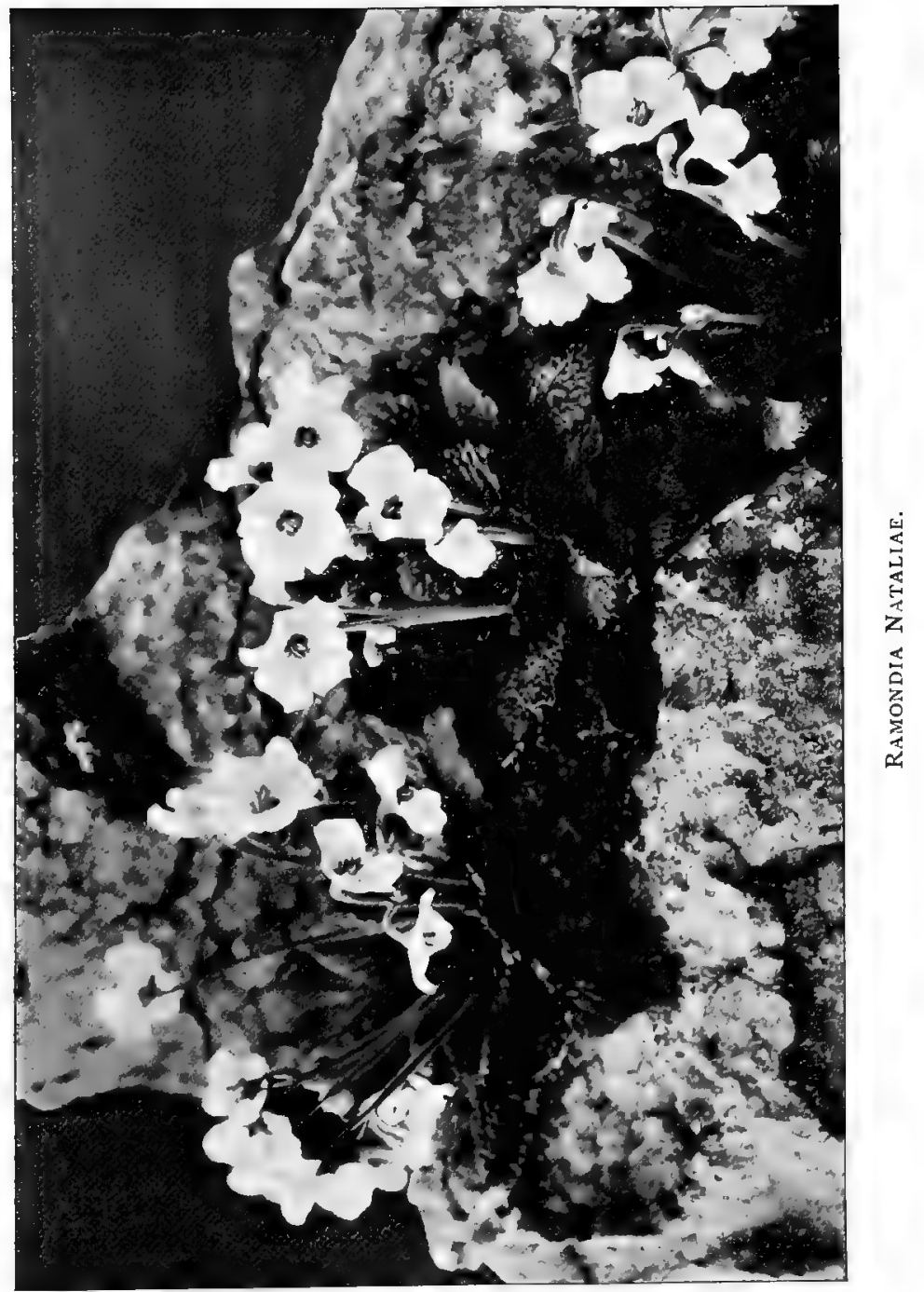


The Cardamines, again, the big Cuckoo-pints, are handsome if large and stout-for a damp out of the way place beyond the bog, where larger things have sway. Bulbifera has fine fern-like foliage and loose spikes of large pale purple cruciform flowers; enneaphylla is more brilliant; digitata is very free-growing and weed-like, recalling an exaggerated Lady's smock; and the double form of this, Cardamine pratensis, itself, is quite a pretty little creature, choicer than the others, freegrowing in any decent place, and coming not only abundantly but faithfully from seed. But over nearly all Crucifers lies the trail of the weed or the coarse vegetable; the giant cabbage Crambe cordifolia, eight feet across the vast mass of its rounded leaves, and sending up to ten feet or more the snow-white fountain of its innumerable little blossoms, is the glory of this ugly race at one end of the scale, a fine, easy plant for some very bigh point, in any good rich soil. At the other end are the delightful miniatures, Morisia, Iberidella, Petrocallis. And not unworthy of being associated with these is the charming Cardamine trifolia, most choice for a cool shady place under the rock; forming a neat mass of very dark green leaves triply divided and about three inches from the ground. From this sombre carpet rise many six-inch spikes of large flowers, brilliantly white, and arranged daintily upon their stems. In earliest summer this plant lights up its corner with a clear gleam recalling the fierce white light that beats upon a throne.

Parochaetus communis is a Himâlyan, a strange ramping trailer, that by general ageement, thrives best with damp treatment. In appearance its long, prostrate shoots are exactly like those of some clover, but the big blossoms are borne by themselves on long pedicels, and are pea-flowers of a rich and faultless azure. This lovely 
thing is, when suited, a tremendous invasive grower, and, personally, I believe its hardiness to be beyond question. But occasionally in bad winters and unpropitious places, it shows signs of a rickety constitution, violently as it grows, when it chooses. And therefore it will be as well, when in doubt, to give it a careful sheltered bank, very well-drained, where cold winter damps cannot lodge, and where the soil is light and good, exposed to full sun, yet safe from blasts and rigours. Yet remember, if you give Parochaetus these advantages you will have to reckon with the certainty of his eating you out of house and home in half a season. Therefore let nothing else of choice be planted in that select sheltered corner-except Tulips, perhaps, and other precious bulbs. Never mind if, at first planting, your infant Parochaetus looks a mere spot of green on an acre of bare earth. In a month the Blue Himâlyan Pea will have covered all his space, and probably a great deal more as well.

As for Potentilla Comarum, this native Potentilla, interesting and curious, can only be admitted to the roughest, rankest of wet places. It is never very effective-a rampant low spreading thing, with big flowers of a dingy chocolate. Nor have I very much love for Chrysobactron Hookeri, a smallish yellow Asphodel of about eighteen inches, which thrives in cool wet corners of the bog. Though bright and pretty, it is not a very distinguishedlooking plant. Far otherwise is it with the Bog-bean, best-beloved native of our marshes-bean-like in foliage, spreading its creeping branches abroad with unrelenting speed, and sending up countless spikes of its big cupshaped flowers, all shaggy with pink and white fur, overflowing with a foam of snow and cream. For shallow water, or a broad muddy expanse, nothing could be finer. But this is a true ramper, almost indestructible. I made a bed for Rhododendrons once, took out the soil for three 
feet, and put at the bottom a lot of garbage, including a quantity of superfluous Menyanthes, weeded from the lake. Through three feet of ordinary dry soil those mutilated sprays ran up to the level of the upper air, and have continued to flourish ever since-though I admit they never flower.

Though Menyanthes is not common in this country, I often find it, curiously enough, growing desperately among the rough grass in high moorland bogs, where it throws a few tentative leaves from year to year, but can no more flower than Convallaria maialis in the crevices of the denuded stone-flats above. Probably, as there was once more copse for the Convallaria, so there was once much more water for the Menyanthes, which was thus able in old days, before the draining of the land, to climb higher and prosper with greater freedom. Now its lowland haunts have almost all been cultivated out of existence, and it only lingers in these difficult inauspicious spots high up on the mountains.

Of tiny, tiny things for the bog-garden I will now mention three of commanding merit. The first is Myosotis Rehsteineri, if that be its correct name-a wee Forget-me-not, spreading along the damp rich ground, with smooth bright green leaves, and spikes of azure blossom about two inches high. This, however-I do not know whence it hails, -is not of absolutely trustworthy constitution, and must be carefully looked after if it is not to get crowded out and worsted in the battle with fellowplants, winds and weather. The next is Mentha Requienii, a little Mint from Corsica so microscopic as to be hardly larger than a lichen. This little plant grows into spreading invisible mats over any damp soil, and you spend your life in utter ignorance of its existence, until one day you tread heedlessly over what seems ordinary naked earth, and are instantly assailed by the intense 
pungent protests of bruised mint, filling the air for yards with its fierce fragrance. Mentha Requienii hails from Corsica, and so might well be rather tender. However, after the hardest winter you are pretty sure, next summer, to come on new patches and tracts of the little Mint, smallest of its kind-smallest flowering plant in cultivation. 'The last is a Novelty,-always to be mentioned with an Honorific capital, though it isn't a bog-plant, and though I don't know its provenance, nor the explanation of its jaw-breaking name. Helxine Soleiroli has only just come into cultivation, and bids fair (Nertera, the fruiting Duckweed, so like a scarlet-berried Lemna, being half-hardy, as also is Mitchella) to be the most important carpeter in the garden, almost beating Arenaria balearica out of the field. Helxinê grows as quick as a dream or a fungus-developing into a dense sheet of verdure like a wee Ficus, with round leaves in pairs. It grows with equal frenzy in good soil or none at all, on bare rock or rich slope, in blazing sun or dense shade. In summer it breaks out into blossom-into a profusion of microscopic flowers that give the whole plant the effect of being powdered with gold dust. As a final recommendation, every shoot and fragment of the plant will strike root and grow, no matter how small, no matter where, nor how recklessly, inserted. Perhaps it is not everywhere, nor invariably, to be trusted in winter, but in all except very unfavourable corners $I$ believe it perfectly safe; and anyhow, one reserved pot will give you a myriad new plants for next season. 


\section{CH APTER XIII}

\section{$\mathbb{T h} \mathfrak{d a t}$ date $=\mathbb{B}$ arden}

Advice to those about to build a Water-garden-DON'T. Not that the Water-garden is not a joy and a glory; but that it is cruelly hard to keep in order and control unless you are master of millions and of broad ample acres of pool and pond. Water, like fire, is a good servant, perhaps, but is painfully liable to develop into a master. As Webster's Flaminio says of women, water, to the gardener, 'is either a god or a wolf.' How many little ponds are unguardedly built, only to become mere basins of slime and duckweed? How many larger pools are made, only to fill with Chara, Potamogeton, and the other noxious growths that make its depths a clogged, waving forest of dull brown vendure? 'The fact is, a pool-not an easy thing to build and set going-is of all things in the garden the hardest of all to keep in decent order. Some of its choice inmates devour and despoil the smaller ones; water-weeds increase and multiply at a prodigious rate; dead leaves drift thick upon it in autumn, slime and green horrors make a film across it in summer.

Contrast with this grim picture the water-garden as it glisters before the sanguine eye of him who contemplates possessing one--that crystal expanse, starred with goblets of Nymphaea, those neat yet luxuriant shores aglow with every glorious plant of the marsh. But the ideal water-garden I need not draw from my own words. The ideal water-garden has been described, once and for 
all, in the Parable that tells how Brahmadatta the King made and adorned a marvellous lake to allure the Most Perfect One, Our Lord Buddha. You will find the tale in the Swan-Birth Story of the Blessed One.

For in those far days of which no history preserves a hint, the Bodhisatta-Soul was incarnate in a white swan, of beauty, strength, and holiness incomparable, ruler of many hundred thousand swans that all dwelt upon a lake of surpassing loveliness, remote from man. So there they faithfully obeyed his sway, and that of his General in Chief, Sumukha, hardly less refulgent in purity than the Swan-King himself. Now, in the latter years, that then lay as many ages down the future as now they lie belind us in the sacred past, Sumukha the white was to be the well-beloved Ananda, standing for ever at the right hand of Our Lord Himself. And still, in their humbler stages, Bodhisatta and Ananda moved forward side by side, preeminent over all their kind in wisdom and virtue. But Brahmadatta, that reigned in Benares, heard of this great swan host, and conceived a strong desire to behold it, and, above all, to capture the snowy King and his chief friend, the general of that winged army. So Brahmadatta, on advice, set himself to create a lake yet more perfectly beautiful than their own, that so the swans might be lured into the clutches of the King. Not too near his park and palace he built it-' a matchless basin of pure water, adorned with innumerable water-plants, enriched with lilies and lotuses in a hundred different kinds. Flowery trees, bright with their quivering sprays, surrounded its shore, as if they had taken possession of the place in order to enjoy contemplation of that water ; swarms of bees, as if attracted by the smiling lotuses that lay rocking on its gently trembling ripples, hovered and roamed across its surface. Here its beauty was enhanced by different groups of water-lilies, sleepless under the 
tender touch of the moonbeams, which made them like patches of white moonshine a-gleam through dark foliage. And here again, in places, the pollen of lotus and waterlily, wafted by the dainty fingering of the ripples, embroidered the shore as if with fine lace of gold. And in yet other places, where it was carpeted with filaments and lapsed petals of lotus and lily, the water had a wide splendour, like a gift of homage and glorification. Yet another beauty was due to its limpid tranquillity, so transparent as to show each line and scale and curve of the innumerable fishes, whose flashing movement were no less plain to view than if they had been wheeling silvery through clear sky. And here the elephants, coming to dip their trunks, blew forth cascades of spray that glittered like loosened strings of pearl. And all the lake was so brilliant that it was the very mirror of the stars, daughters of our Lady Moon. Gay birds abounded there, and their warbling resounded across the water.'

Thus was the lake constructed by Brahmadatta the King for the allurement of all birds that fly; and he ordered then a proclamation of safety, and pronounced that the lake, with all its lilies and all its lotuses, was the gift of King Brahmadatta to the birds, that they might come and dwell in safety there.

And so his wicked scheme came to success one day, - when autumn had drawn away the curtain of dark cloud, and had scattered its beautiful gifts abroad, widening infinitely the clear purity of the horizon; the lakes were glorious to behold, with their translucent water, and the crowded lilies opening in fullest brilliancy. It was in the time when our Lady Moon, flashing rays of doubled glory, reaches the highest pitch of loveliness and youth; 'when earth, robed in the splendour of innumerable harvests, offers her richest beauty.'

Thus begins this simple pious old parable, which, like 
all the stories in the Birth-Garland of Our Lord Buddha, preaches superhuman perfections of charity and selfdenial through a hundred imagined incidents in the bygone births and deaths of The Utterly Perfect One, claiming no authority, of course, as bistory or dogma, but, like the Gospel parables, making exorbitant demands on poor mortal virtue, in the hope, by asking a very great deal, of obtaining perhaps a little. And, if you care to read further, you will learn how two young swans of the swan-kingdom came soaring over the lake of seduction; how they reported ecstatically on it to their King; how, after long deliberation, against the counsel of Sumukha, the Bodhisatta with all his followers rose up and flew to Benares. And there, on that lake of temptation, the Bodhisatta was snared by a cunning fowler, at the command of King Brahmadatta. Mindful as always of others only, Bodhisatta uttered a loud warning cry, and in an instant all his host of swans rose up into the air and departed, making great lamentation. Sumukha alone remained at the side of imprisoned Bodhisatta. And there Sumukha and Bodhisatta strove in generosity, one against the other: Sumukha refusing to seek safety for himself and leave his lord a prisoner; Bodhisatta insisting that he should go and save himself while yet there was time. But while they pleaded one with another, the fowler rushed forth and found the two royal birds an easy prey. But only one of them was bound in the snare. So he was greatly astonished, and eagerly asked Sumukha why he had not used his opportunities of escape. Then Sumukha replied to him in human words, 'whose sonorous firmness showed his virtuous nature,' that if the fowler held Bodhisatta in a snare of cords, so he, Sumukha, was held by Bodhisatta in the far stronger snare of the Bodhisatta's holiness and wisdom. 'And the fowler fell into ecstasy, and the hairs 
of his neck stood on end.' Then Sumukha pleaded with him, urging the glory of merit he would reach through releasing Bodhisatta. And the fowler, adoring the selfdenial of Sumukha, was melted to the depths of a heart that his harsh trade had never hardened. So he unbound the cord and released Our Lord Bodhisatta. And then in gratitude, both Sumukha and Bodhisatta offered themselves freely to the man, that he might win rich rewards by taking them, unbound, as a spectacle to Brahmadatta the King. So the fowler carried the two royal swans into the presence of the King, and before Brahmadatta the Holy One lifted up his voice for holiness, unfolding the Most Blessed Way; and the fowler bore witness that the ardour of Sumukha's prayer for the release of Bodhisatta arose from pure readiness to lay down life for his master. And thus, after much profitable discourse, the King was filled with wonder and piety; he released the two royal swans, "who soared upwards through the clear autumn air, dark-blue as a polished sword-blade,' and departed to their old waters, where a myriad swans received with clamours of joy the return of their Lord, with Sumukha close behind him as a shadow. But Bodhisatta, overflowing in compassion for his neighbour, returned again and again to the King, and opened to him the perfect path of wisdom and release from sorrow. And the King honoured the great swan respectfully, with bowed head and humility.

Beautiful though we may build our ponds and keep them, I fear it is not likely we shall ever allure a Bodhisatta. Nearest approach to a divine swan will be a very worldly heron, filled with belly-thoughts and murder, who will come to take toll of any little frogs and fishes that may be enjoying our waters. Nor are saintly berons, I believe, so common that the prayer of frog or fish may turn their hearts to kindness; therefore if you want to 
nourish goldfish in your pools, see to it that the water be deep enough to guarantee them from the heron's marauding bill. Indeed, the too common fault in pondbuilding is shallowness, which fosters slime and waterweed to an intolerable extent, and makes more disastrous the silting up of dead leaves in autumn and winter. A shallow pond must needs be exhaustively cleaned out each season, and even so the job will never be satisfactory for more than a month. Intolerable sight, a shallow little basin all a muck of weeds and autumn wreckage; not to mention that water-weed clogs and ultimately conquers even the most stalwart Nymphaeas. Therefore I would prescribe no less a depth than four feet for the pond, and will now begin at last to prescribe for those who refuse to be daunted by my jeremiads, and insist on having a water-garden. And, first of all, let me say that if the water-garden be hard to keep in order, yet, if kept in order, dainty and clean, it is the very jewel and eye and omphalos of the rock-garden, doubling its own beauty by the neighbourhood of grey stone, and doubling the beauty of the stone by its own limpid light. Pray, then, and make offering to the high gods that you may have running water in abundance at your disposal. So you shall have a little mountain stream to bubble and splash through the rock-garden, trickling dispersedly down over the shoulder of the Alpine bog, and so to leap like Niagara into a bright sparkling little lake below.

In planning your lake, be very careful of its curves. Map and scheme with the utmost deliberation. Unfortunately, this is not a question for general law-giving, as the lie of each piece of ground must determine the proper shape of any piece of water. But a misplaced bay or promontory will be as fatal to the harmony of your design as a duly, tactfully placed one will be satisfying and completing. Therefore go at the shaping of 
your pond with pains, and don't rest content with a mere circle or oval, like the bed of some great pie or pudding. Excavate, then, to four feet and a half at one end-for I advise a kidney-shape, with many variants, as the best general design for the pond-and at the lower end have a lesser depth-say about three feet to three feet and a half. For remember that this is not your depth as you will have it, since the concrete bottom will swallow up at least six inches if you wish to be quite safe against any possible shiftings, frosts, and other disasters. This, with a superimposed six inches of soil, will leave you, at your deepest, three feet and a half of water at the deeper end, and two and a half at the shallower. If you delve any deeper, you may have too much water for some of the frailer Nymphaeas; if you spare trouble and make your pond shallower, you run the risk, in hard winters, of having the pond frozen solid, so that the cement, unable to contain the expanded mass, cracks and bursts.

You will add a notable advantage and beauty if you give the pond a false wall. That is to say, make it a solid tank of cement, with four sides and bottom, quite simple. Then, in brick, build an inner wall, rising to within an inch or so of water-level. If the narrow trench thus formed-it need not be more than eight inches wide - be filled with rich soil on a rubble base of two feet or so, it will give you a most lovely ring of bog-plants round your lake, being perpetually wet with the water that just overtaps the false inner wall, and for ever percolates into the soil. There is, of course, no need to have this all round, if you do not want it, but one of the loveliest pools I know sits high on a Surrey down, and owes half its beauty to its complete girdle of Iris, Spiraea, and fenplants generally.

Again, nothing looks better than to diversify your bank here and there with some bold feature. Here and 
there round my two ponds I have immense boulders of water-worn mountain limestone, specially selected blocks, hollowed by wind and weather, in which I grow waving masses of Saxifrage and Dianthus over the water; or, yet again, you may very effectively bring the line of your lake round under some dominant cliff of the rockwork. I have done this at one point of my New Garden, with the most commanding effect. The one drawback is that the walk round the pond-an indispensable feature-is narrowed, at this point, to an irreducible minimum of about six inches. So that if, for instance, one wants to photograph any plant on the promontory, one runs the risk, in the course of the photographer's manœuvres, of walking innocently backwards into four feet of water.

And, for a last word on shape. I can give one very definite and valuable piece of advice. Wherever you make your ponds, never let any consideration seduce you into allowing straight lines or anything approaching to a square or rectangle. One of the finest collections of Nymphaeas that I know is quite spoiled from the decorative point of view by being grown in a chain of rawlooking little pools, more or less square, bounded by stiff, straightish lines, and looking sadly artificial in their bevelled banks of lawn. Close by there is a pool built with proper wildness and elegance of design, and the contrast is beautifully instructive. Of course, when you are dealing with the formal garden, and are growing water-lilies as splendid adjuncts, not as the be-all and end-all of the scheme, your square pool is well in place. Under some stately terrace wall, what could be more fitting than a long, long pool, perfectly rectangular, rimmed with dressed stone, embedded in shorn turf, and containing crowns of Nymphaea at regular intervals? But for the pool as the completion of the rock-garden, anything at all suggestive of formality, such as a straight 
line or a bare grass-edging, should always be most rigidly eschewed.

Before we turn to the actual aquatics themselves, there is the bordering rim of swamp to be planted. Here, according to your width, you may have as many plants as you please. Seeing that the glory of the bog-and-watergarden rages from midsummer through autumn, it is as well to accept the fact, and plant for August effect. Here the soil, of course, will be too wet for all lilies except pardalinum, Grayi, Roezlii, canadense, and superbum. But you will have clumps and tufts of the Japanese and the Siberian Iris, you will have as many of the damploving Spiraeas as you have room for, you will have one. bulky mass of Senecio Clicorum, groups of the WillowGentian, stately colonies of T'halictrum aquilegifolium, and the herbaceous tall Phloxes;-remembering always that in planting for pomp of effect the secret is to strike a note of colour hard and firm and once for all, rather than to go on repeating it, no matter how well-beloved, here and there, in a spotty and uncertain manner. Plant your one big clump of a favourite plant, and then be done with it; don't spoil the 'coup' by vain repetitions.

Most dazzling of all colour-schemes is that afforded by the tall American Lobelias and their hybrids. In shades of the most fearful vermilion range cardinalis, fulgens, and the various roses, red and pinks of Gerardi, graceful and lofty; then comes the group of syphilitica, bearing rather shorter, stockier spikes in sapphire, amethyst, and violet. Also there are fancy-named hybrids, such as Queen Victoria, a glorified cardinalis. All these, hardy and robust, are admirable for a big group at the water's edge, and at the same time in any fair climate may be trusted to look after themselves in any deep rich soil. But, at the same time, their colour is so keen, clean, and startling, 
that you have to be very careful how you introduce it. Not a Spiraea in the whole garden but shrieks piteously in the neighbourhood of that relentless vermilion; the Panther Lily turns acrid, and the orange of Senecio Clivorum completes a chord almost too powerful for endurance. The only other Lobelia of importance-for radicans has turned out unable to bear our sunless summers, and grows perpetually without flowering ${ }^{1}$ is the queer little aquatic Dortmanna. Lobelia Dortmanna inhabits mountain lakes in northern England, Wales, and Scotland, growing, like any Chara, right at the bottom of the water, making its little tuft of fat, linear, blunt-ended leaves under four feet or so of Alpine tarn. Then, in summer, up through the ripple comes the flower-stalk, and unfolds three or four large flowers of very pale China blue, just above the surface of the water. I first saw Dortmanna among the Welsh mountains, in drying mud-flats beside a little lake, and, though I confess I have never yet grown it, I see no reason at all why it should not be as easy as it certainly is pretty. As a rule, difficulty and ill-temper are not the prevailing faults of aquatic plants. Rather the other way.

'I'here are one or two other cautions I would hint as to planting the edge of your pond. Do not overdo the use of Iris. The Irises, in their sword-like foliage, give you a charm of the first order. Do not cheapen it by too frequent use and repetition; let us have one or two Iris clumps, contrasting with the other, lusher leafage, rather than weaken the effect of both by dotting Irises too copiously along the shore. I would counsel three or four clumps of sibirica, arranged in a row-sibirica is extremely decorative thus, in a row-and one sheaved mass of Kaempferi, at a commanding, prominent point of the edge; while, of course, you will use, not more than once,

1 This last winter, too, has finally cured it of even that good habit. 
the tropical growth of gigantea and the kindred of gigantea, spuria Monnieri and the rest.

Another small hint; it is no bad thing to make your edging of uneven height-mat is, especially, to build it up, at one point, if possible, to a bulk of rock-work, impending immediately over the water. And, for such a high point most delightful is the common Great Solomon's Seal, whose tall, indescribable majesty is thus shown to the very best advantage. Stately is the Great Solomon's Seal always, but most particularly in autumn, and, if you give it such a lofty lonely place it will return you a picture of pure wan gold in late autumn, magically soft and beautiful, the clearest softest note of all amid the russets, saffrons, and sere browns of those last dreadful days. On a still, chill autumn afternoon, amid the bronze and purple of dead fern fronds, the withered seed-vessels of Iris, the dry brown plumes of Spiraea, tower the clean gold croziers of the Polygonatum, mirrored, pale and clear, in the brown sad water, choked already with wreckage of leaves, blue with ghostly reflections of the sky. And those arched sprays of pure yellow seem the very incarnation of autumn, uncomplaining, phantasmal, motionless, unutterably meek and tragic.

Along the outer edge of the bog belt, under your eye as you stroll round, you will, if it be wide enough, have all the choice little bog plants for which you have room -Primulas, Gentians, small Saxifrages, Alpine Buttercups, and so forth. But, seeing that the small bog plants are so small; and the large bog plants so very large, not to say rampageous, it is far best to give up a section of the belt entirely to little things, rather than try to grow them all round under the shadow of larger neighbours. Middle-sized robust things that will be useful all round, on the outer edge of tall giants such as Iris Monnieri, are Gentiana asclepiadea, all the Globe-flowers 
Ranunculus aconitifolius, Anemone rivularis, Thalictrum aquilegifolium, Lychnis haageana, Spiraea japonica, with its fellows, and Mimulus Model and Mimulus Brilliantwhich are also magnificent on the inner edge, pushing masses of rose and vermilion right out over the waterand, of course, besides the larger Primulas, pulverulenta, japonica, and siklimensis, the invaluable, gorgeous Myosotis palustris, which, like the Mimulus, is no less beautiful and effective for the very water's edge itself.

If, too, you plant Potentilla Comarum and Menyanthes trifoliata on the rim of the pond, they will both spread and ramp forwards across the face of the ripples. Calla palustris, on the other hand, is, I think, happiest when within root grip of wet fat mud. The Potentilla and the Menyanthes thrive quite happily, emitting tufted silky roots into the water, but the bog-Arum prefers the help of a little soil, making mats of heart-shaped leaves across the wet marsh, and sending up all along its branches the white flowers, miniatures of Calla ethiopica. Orontium aquaticum, another Aroid, with yellow spathe, loves shallow water, but, for my own part, I have never admired its colour, its shape, or anything about it, and therefore have never made any prolonged effort to grow it. Hottonia palustris is a dainty native, for quite shallow depths, filling a whole pool with white fibres and masses of the finest lacy foliage, from which shoot up above the depths, whorled spikes of very large flowers of a very pale rose-violet. With this I have never had much to do. My efforts to establish it did not prosper, and, so heartily does it grow when the will takes it, that I do not altogether regret the fact that, in my case, the will was lacking.

Of course, if you want a very full collection of waterplants, you will not only build one false wall, giving you a marshy edging to your pond, but also, within that 


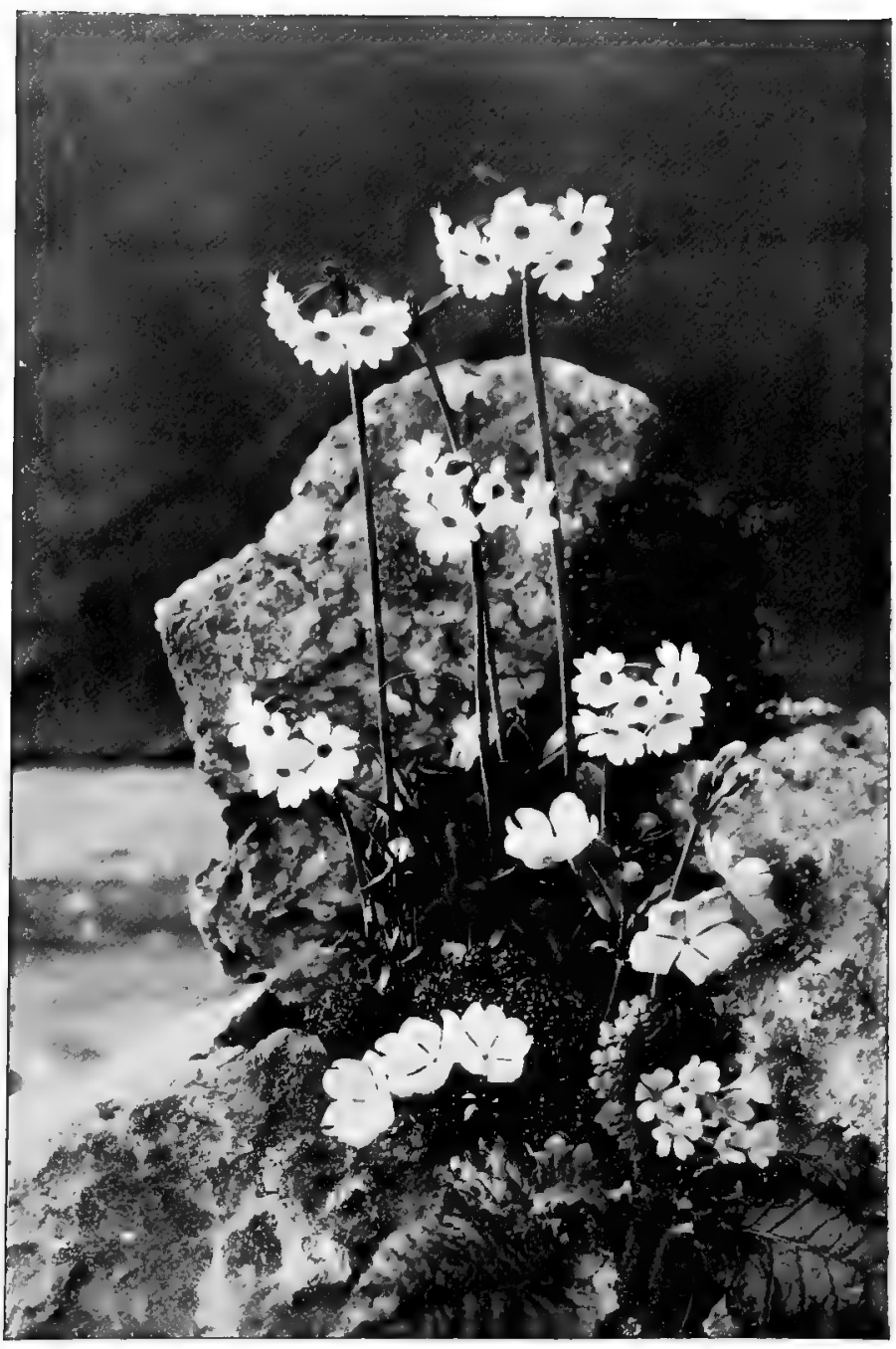

Primula involucrata, Primula cortusoeides, Primula deorum. 

again, you will contrive a second, lower, false wall, forming a trench whose surface shall be covered by six inches of water or so. Here you will have many pretty and interesting things to grow, which would not enjoy the greater depths that suit the robust Nymphaeas, and, at the same time, want more abundant wet than they could get in the marsh. Among these the Arrowroots stand high, though personally I have never cared for any of them. They are very free and vigorous, about a foot or eighteen inches, with abundance of arrow-headed, glossy leaves, and spikes of large, three-petalled white flowers, whose general effect, despite their size, is dull and cold, owing to the rather repellent shade of their white. They have double forms, too, and at least one rare species, montevidëensis, with much more brilliant flowers, but unfortunately of rather doubtful hardiness. Sagittaria japonica is the best ordinary one, better than our own native Sagittaria palustris. Then come the Alismas, of which our common native, Alisma plantago, is a most decorative plant, with big handsome leaves, like a horseradish, and tall, very graceful loose spires and showers of innumerable tiny white flowers. This, unfortunately, is a dreadful weed, and sows itself everywhere. On the other hand, it does not spread or run, and is always easy to uproot. Alisma natans is a very elfin little dainty water plant, absolutely aquatic, and a great rarity, occurring here and there in our mountain lakes of Ireland and the West. The stems of this are so fine as to be invisible. Over the water lie little round leaves of glossy green, and big white flowers, three-petalled, that seem to float detached, loose jewels on the surface. Similar is Hydrocharis Morsus-Ranuc, but commoner, larger in growth, and altogether less brilliant. Rare in the marshes of East Anglia is the water-Aloe, Stratiotes aloeides, exactly like a thorny, submerged alne, with 
spikes of whitish flowers. This, however, with me at least, lives so far under water, and flowers so sparsely, that it really has no value for the garden. Azolla caroliniana has the habit and the leafage of Alisma natans, without the brilliant flowers. Trapa natans, the waterChestnut of Italian lakes, is another interesting aquatic, not perhaps absolutely hardy, with queer thorny edible nuts, contorted and devilish in outline. Then there are our own river-buttercups, Ranunculus aquatilis, in many varieties, with fine ferny foliage and abundance of big white blossoms. This, however, is so ramping a water-weed that it should never be admitted to any pond that is not measured by the mile. Much as the same applies to a cousin of the Gentians, Villarsia nymphaeoeides, with leaves exactly like a wee Nymphaea, and solitary flowers, large, fluffy yellow cups, like golden, single-flowered Menyanthes. This is a fearful invader, and has choked up every piece of water into which it was ever admitted. On the other hand, its near, and prettier relation, Limnanthemum villarsioeides, is not trustworthy in point of rusticity.

If you crave for curiosities, in some wet spongy place of the inner bog, you might grow the Sarracenias and Darlingtonia californica. Both Sarracenia purpurea and Darlingtonia californica are hardy, if well treated, but the Pitcher-plants require a good deal of attention, and, to my taste, are not altogether worthy of it, though their deep swelling jugs of bronze, emerald, and purple are strange enough for anything, and only surpassed by their pendulous flowers, like enormous blind Poppies designed by Aubrey Beardsley, and carried out in lard, coloured with various shades of red, green, and yellow. These odd rare creatures require a great deal of moisture, a sheltered warm position, and very perfect drainage, if they are to be permanent. 
The Wood-Lilies, on the other hand, require no attention beyond good planting, and are among the grandest of all plants for any corner of the garden wet or dry, in any cool moist climate, in any deep rich soil-peaty, loamy or, best of all, leafy-but not limy. In the copse, in the wild-garden, beside the stream, on the shady rockwork, wherever Solomon's Seal and Lily of the Valley will thrive, there may you also have clumps and drifts and beds of Trillium. And Trillium, for general garden purposes, means Trillium grandiflorum, the sovereign of the race. The great Wood-Lily, in growth and texture and height, is exactly like a three-leaved version of our own rare north-countryman, Paris quadrifolia, from the Alpine woods. But who is there that does not know the flower, that huge, tripetalled snowy goblet, so different from the inconspicuous little quaint green bloom of Paris? Trillium grandiflorum stands well ahead among plants of the first rank for the rock-garden,-of perfect ease, hardiness, and persistence. Slugs and mice, however, are its bitter enemies here-or perhaps ardent inarticulate admirers, who can only show their admiration by eating its object. Its rosy variety is lovely, but cannot possibly improve on the snowy type-exquisite as is the harmony that my plants are now making in a big bed which they share with their contemporary, profusely pink-belled little Menziesia empetriformis. And Trillium grandiflorum will vary very much in size and splendour from one importation-some forms almost reaching the snowy magnificence of a young Lilium candidum, or Magnolia Yulan, while others are comparatively-but only comparatively-poor. Trillium sessile has beauty in its three broad marbled leaves, but its big flowers are narrow in petal and dull in colour, except in the variety californicum, which is larger and longer than grandiflorum, of a bright, warm white, but inferior in effect, owing to its 
narrowness of petal, and its habit of sitting close upon the leaves. Trillium erectum and Trillium stylosum are dull, to my taste, and dowdy, - pink and purple. Trillium erythrocarpum is a tiny jewel, delicate and rather difficult, small, with snow-pure flowers, like miniatures of grandiflorum, but with a blotch of blood-crimson at the base of each segment. This requires attention on the choice peat-bed, but all the others thrive in any open woodland soil, free and moist, luxuriating in the filtered light of a thin copse or hollow in the woods. However, the Woodlilies, blooming in May and June, though lovely by the water-side, are perhaps more glorious still for the lilybank and copse and rockwork. They have great resisting power, too, for I remember seeing one in Hokkaidoprobably Trillium secundum, a small version of grandiflorum, coping successfully with the roots of Bambusa Veitchi. The Bamboo covered the country by the mile, and not a square inch of soil can have been free of its roots. Yet everywhere amid that two-foot jungle were visible the white stars of the Trillium, quite unsubdued by the rambling growth of the Bamboo. This, however, must not be literally presumed on in the garden. Except into the wild garden there is not a Bamboo that can be trusted-making an honourable exception for Maximowiczii and erecta, graceful and effective, like Pampas and stripe-leaved Eulalia zebrina, at the edge of the water.

Now dive we into the depths of the pond itself. From two to three feet is the happiest depth for beautiful Pontederia cordata, with broad, splendid leaves, and tall spikes of blue flowers that unfold too late in the season to be of any use to me. The Pontederia will also grow in shallower water, but one wants to avoid, as far as possible, the peril of frosts. The same applies to the even more splendid and tropical Thateia dealbata, which is hopeless for my climate, and to the common Arum of the greenhouse. 
With a pool of two feet depth any one may hope in rich deep soil to have blooming beds of Calla ethiopica, perfectly hardy as the plant is-or rather becomes, if its roots are planted in water beyond reach of any but an extraordinary frost.

In the south and west of England indeed the Calla has become a water-weed, blooming by the acre; and there is no sort of reason why, in any fairly clement part of England, the same gorgeous result could not be achieved. But the Calla must be planted in a broad sweep, and I have not had space enough so far to deal with it massively by the hundred yards. As an isolated crown I flowered it well and enjoyed it for several seasons in my old pond. But this was so ridiculously shallow that it froze solid and cracked every winter. After three such experiences the Calla grew peevish and expired. Now, however, that I am restoring the pool on a proper scale, I shall renew my experiments with the Arum, and hope for finer and more permanent results, even though my pond is not large enough for it to be used as freely as it should, to gain its full effect.

Two other important plants are Aponogeton and Butomus umbellatus. The Flowering Rush loves shallow, sluggish water, and is found by streams and canals all Lingland over-in appearance a big lax-leaved rush, until you see, on tall stems, its flattened heads of large pale pink flowers. This flourishes in any water not too deep, and its only drawback is its tendency to become a weed. $A$ fortiori the same applies to the giant Bulrush, magnificent as it is, and to pretty, fluffy-balled Sparganium ramosum, and to the great Dock, one of the handsomest of foliage plants, no matter what exotic rivals you may adduce. Much slenderer, and safe to admit, though, is Typha minor. The lesser Bulrush is far slighter and more graceful than its major-a fine gracious thing, sufficiently rampant in 
shallow muddy water, but not dangerously prolific, if kept in hand-and very delightful with its long thin leaves and its refined dainty spears of brown plush. The Aponogeton is quite different, so like a Potamogeton in growth that I am always confusing the names. It throws its oval leaves along the surface of the water though, not particular, I think, as to depth, but perhaps preferring about eighteen inches to two feet. In midwinter and through a long scattered season unfold the curious, divided spikes of white flowers, deliciously hawthornscented, and appearing in such abundance as to make the water look as if covered with drifted snow of petals. Though the Aponogeton hails from South Africa, it is absolutely hardy, if given sufficient protecting depth of water, and left to look after itself in some still pool.

Almost all aquatics dislike running water, or rather water in too rapid movement. And, at the head of the list come the Queens of the Water Garden, the royal Nymphs themselves. From the common white WaterLily of our lakes to the newest reddest dearest hybrid, all alike must have deep tranquil water, unworried by a violent current, though not, of course, in a state of stagnation. The best thing, in cultivation, is to give your pool, if you lack a mild feeding stream, a tiny little incessant jet at one end or the other, to keep the water perpetually fresh and moving, to the confusion of green slime and weed.

There is no need, now, to trouble with the common white Water-Lily. So much larger, so much stronger, so much more brilliantly white are the big foreigners and hybrids, candida, gigantea, Richardsoni, gladstoniana, of which Richardsoni has the merit of pushing its great semi-globular white blossoms high above the water. Between any of these and the others in the matter of vigour, there is nothing at all to choose. For the 
larger Water-Lilies are of the most weedlike vigour. Plant them in a hamper filled with clay and manure; drop them into a still pool; cut away the trees so that they may have full sun; and then they will grow like rhubarb, and flower like French Marguerites.

Of the yellow Water-Lilies-I am talking of Nymphaea, of course, not of the common vulgar BrandyBottle, and its brother, Nuphar Advena, from America, whose upstanding foliage is very handsome, though its dull yellow globes are no better than those of luteumthe panhypersebastos is marliacea Chromatella, magnificent in its wealth of immense foliage, bronze green and violet, doubly and trebly magnificent in its huge sulphur flowers, generous in build, ample in breadth and texture of petal. Flava is half-hardy, lutea is smaller; no yellow-hardly any other Nymph, approaches gigantic, splendid Chromatella. The nearest approach is the similar colossea, largest of all the race, with great blossoms of soft pale pink. The American hybrid, too, William Doogue, has the same ample splendour, and a deeper shade of flesh.

The other rosy Water-Lilies are inferior, though pretty. Their tendency is to run towards thinness of petal and starriness of outline. Also they are almost all of frailer, smaller growth, adapted to shallower water. Thus are the Laydekeri lilies, purpurea and liliacea; the Carolinianas, rosea and perfecta; odorata and odorata carnea, and rare blushing sphaerocarpa from the far North. Either a sport or a seedling of sphaerocarpa is bright frail Froebelii, weak in growth, small in bloom, but of a rich carmine crimson. This is a delicate little treasure,- the only Water-Lily that is, - and should have less depth of water and a choice place. Some of the hybrids, too, have the starry thin form I cavil at in the smaller pink lilies; it mars the effectiveness of Seignouretti, ignea, flammea, Robinsoniana, hucida-lovely, subtly- 
coloured things that they are, in shades of fire, rose, dawn and cream. But among red Nymphaeas there are three glorious plants. The first is William Falconer, an American, small in growth, and not enormous in flower; but the plant is very free and very healthy; the flowers are of the deepest crimson purple that has yet been seen in the family. Ellisiana is a larger plant, with flowers of a fine blood-crimson; the pride of the three, if not of the whole family, is gloriosa, a giant only less than Chromatella in growth, with immense abundant flowers of a dazzling carmine crimson.

For my own part I should be inclined to suggest omitting all the minor Water-Lilies, the Laydekeris, Carolinianas, and so forth (except the charming little miniature, Helvola, for shallow water), and concentrating simply on the best, the largest in growth, the freest in flower, the finest in build and in substance. For, truth to tell, the minor Water-Lilies, however lucent in colouring, are, to my taste, mean and poor in shape. Therefore I would, space being limited, grow only, for the smaller sorts in shallower water, Helvola, William Falconer, and Froebelii; for the full depths, William Doogue, Richardsoni, gigantea, colossea, Chromatella, and gloriosa. For you would miss nothing good, and, as the less is included in the greater, have at your disposal all the glory of the Water-Lilies. And a glory it is. They have a perverse habit, in my pools, of opening in the late afternoon of a dull day; and to go round, in a dank dripping world, and come suddenly on the glowing crimson goblets of Nymphaea gloriosa or Chromatella, expanded among their marbled bronzy leaves, and mirrored flawlessly in the cold, brown water, is one of the garden's most welcome surprises. But when, oh! when shall we, to complete our collections, have a big blue brother to gloriosa and Chromatella, a hardy celestial offspring of scutellata or zanzibarensis? 
The most august, however, of water-plants-and I make no apology to the earthly royalty of Nymphaea, is the heavenly holiness of Nelumbium. But up to this time the Holy Lotus has refused all the blandishments of the unholy West. With hot-water pipes and other expensive illegitimate contraptions, it may be lured, in our pools, to emit one or two pale blossoms, but it must not be trusted in winter, and our summers never ripen it sufficiently for next year's show of bloom. And yet I nourish a hope that if one procures Nelumbium from its most northerly limit of distribution in Japan, from cold places where it is frozen solid for more than a quarter of the year, one ought, in time, to evolve a hardy race that will glorify our garden with a glory as far exceeding $\mathrm{Nym}$ phaea as Nymphaea excels all other glories of the water. This should be no over-sanguine hope, too; for, though there are many Nelumbiums, yet Nelumbium speciosum ranges from southerly Ceylon to almost arctic Japan, and should therefore offer in its range some sturdy varieties of constitution. And no pains are too great to pay for the achievement of that end; to see the Holy Flower, analogue of the human soul, breaking in perfect and flawless loveliness from the filthy slime of the pond. Even so the human soul may break out in perfect and flawless beauty from all the filth and slime of the world. And thus, for its analogy, the Lotus is eternally hallowed, the consecrated flower to that Most Perfect of all souls that ever bloomed out of the world's mire.

THE END. 



\section{N D E X}

Acantholimon androsaceum, 137.

$$
\begin{array}{ll}
\text {," glumosum, } 137 . \\
\text {, }
\end{array}
$$

Acanthus Candelabrum, 140.

$$
\text { ., mollis, } 140 .
$$

," Perringi, 140.

Achillea atrata, 126.

$\begin{array}{ll}\text {, } & \text { Clavennae, } 126 . \\ \text {, } & \text { Jaborneggi, } 126 . \\ \text { " } & \text { Kellereri, } 126 . \\ \text { " } & \text { mongolica, } 126 . \\ \text { " } & \text { moschata, 126. } \\ \text {, } & \text { ptarmica, 126. } \\ \text {, } & \text { serbica, } 126 . \\ \text {, } & \text { sericea, } 127 .\end{array}$

Adenostyles alpina, 131, 225.

Adonis amurensis, 51.

,, pyrenaica, 51.

„ vernalis, 51.

," wolgensis, 51.

Aethionema armenum, 66.

, coridifolium, 66.

," creticum, 66.

, diastrophis, 66 .

" grandiflorum, 66.

," iberideum, 66 .

," jucundum, 66 .

Alisma natans, 271.

, plantago, 271 .

Allium Frdelii, 230.

, hierochunticum, 230.

, kansuense, 230 .

," neapolitanum, 230 .

", ostrowskyanum, 229.

," pulchellum, 230.

", Schoenoprason, 230.

, Schuberti, 230.

, triquetrum, 230.
Allosorus crispus, 248.

Alsine laricifolia, 98.

, ledebouriana, 98 .

, pinifolia, 98.

"Rosani, 98.

Alyssum alpestre, 63.

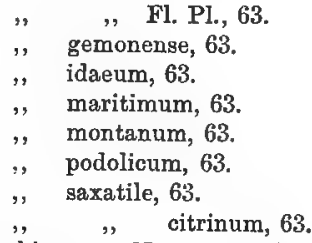

Amphiocarpus Neumeyeri, 128.

Anagallis tenella, 241-2.

Anchusa italica, Dropmore var., 145.

Andromeda polifolia, 244.

Androsace brigantiaca, 91 .

, carnea, 90.

, , eximia, 90 .

, Chaixii, 92.

, coronopifolia, 92.

", glacialis, 155, 237, 242.

"hedraeantha, 91 .

, imbricata, 88-9.

, lactea, 91-2.

, macrantha, 93 .

, Mathildae, 93.

", raddeana, 92.

," septentrionalis, 92.

, vitaliana, 90-1.

Anemone rivularis, 183,270 .

, robinsoniana, 204, 243.

Anemonopsis macrophylla, 50 .

Antennaria dioica, 128.

Anthemis aeizoön, 127. 
Anthemis Biebersteinii, 127. ," montana, 127.

Anthyllis montana, 111. vulneraria, 111.

Antirrhinum asarinum, 148. ", $\quad$ glutinosum, 148.

Aphyllanthes monspeliensis, 245 . A ponogeton distachyon, 275-6. Arabis albida, 62.

" Billiardierii rosea, 62 .

" Iucida variegata, 62.

, Sturii, 62.

Aralia cordata, 120-1.

Arenaria balearica, 98.

$$
\begin{aligned}
& \text { " ciliata, } 98 . \\
& \text { "gothica, } 219 . \\
& \text { ", graminifolia, } 98 . \\
& \text {, Huteri, } 98 . \\
& \text { ". montana, } 98 . \\
& \text { ", norvegica, } 98 \text {. } \\
& \text { ", purpurascens, } 98 .
\end{aligned}
$$

Arethusa bulbosa, 244.

Arisaema japonicum, 249.

Arisarum proboscideum, 248-9.

Armeria caespitosa, 136.

$$
\text { " } \quad \text { cephalotes, } 136 .
$$

Arnebia echioeides, 144.

Arnica montana, 182-3, 229, 242.

Aronicum glaciale, 181-2.

$$
\text { " scorpioeides, 181-2. }
$$

Arum crinitum, 249-50.

Asarum europaeum, 250. , Sieboldi, 250.

Asperula Athoa, 121.

$$
\text { ", odnanchica, } 121 .
$$

Aster acris, 125.

$\begin{array}{ll}, & \text { alpinus, 82, } 242 . \\ \text { ", } & \text { canescens, 124. } \\ \text { " } & \text { cassiarabicus, } 124 . \\ \text { ", } & \text { diplostephioeides, } 124 . \\ \text { " } & \text { ereicoeides, 125. } \\ \text { " } & \text { Fendleri, 125. } \\ \text { " } & \text { Fremonti, 124. } \\ \text { " latifolius, 124. } & \text { Porteri, 124. }\end{array}$

Aster pyrenaeus, 123, 191. ", Townsendi, 124.

Astilbe Davidi, 175-6. " grandis, 176.

Astragalus ambiguus, 110.

$\begin{array}{ll}" & \text { hypoglottis, } 110 . \\ " & \text { mongolicus, } 110 . \\ " & \text { tragacanthus, } 110 . \\ " & \text { Vandasii, 111. }\end{array}$

Atragene alpina, 49-50.

Aubrietia Moerheimi, 61.

$$
\begin{array}{ll}
, & \text { 'Craven Gem,' 62. } \\
, & \text { 'Dr. Mules,'62. } \\
\text { ", } & \text { 'Pritchard's A1,' 62. } \\
, & \text { 'Purple Robe,' 62. }
\end{array}
$$

Azalea alpina, 27-8.

$$
\begin{array}{ll}
" & \text { calendulacea, } 29 . \\
" & \text { indica, } 29 . \\
" & \text { mollis, } 29 . \\
" & \text { Vaseyi, 29. }
\end{array}
$$

Azolla caroliniana, 272.

Bambusa erecta, 46.

$\begin{array}{ll}" & \text { Henonis, 47. } \\ " & \text { Maximowiczii, } 47 . \\ " & \text { Metaké, 47. } \\ " & \text { nigra, 47, 206. } \\ " & \text { palmata, 46-7. } \\ " & \text { pygmaea, 46. } \\ " & \text { quadrangularis, } 46 . \\ " & \text { ruscifolia, 46. } \\ " & \text { senanensis, 47. } \\ " & \text { Veitohi, 46. }\end{array}$

Bellidiastrum Michelii, 125.

Bellis coeruleseens, 125. ", sylvestris, 125-6. Bellium minutum, 126. Bocconia cordata, 56. Brickellia grandiffora, 129. Buddleia asiatica, 20.

"Colvillei, 20-1.

" globosa, 20.

". variabilis, 20.

Butomus umbellatus, 275 .

Cacalia tuberosa, 129. Calandrinia umbellata, 104.

Calla ethiopica, 274-5. 
Calla palustris, 270 .

Callirboë involucrata, 103-4.

Calopogon pulchellus, 244.

Camellia Japonica, 36.

, reticulata, 34-5.

, Sasankwa, 35-6.

, Thea, 35 .

Campanula amabilis, 140.

" barbata, 79, 242.

", floribunda, 140.

," macrantha, 183.

", pusilla, 78-9, 225 .

", raddeana, 140 .

, Scheuchzeri, 81.

Cardamine bulbifera, 255 .

digitata, 255.

enneaphylla, 255. pratensis, Fl. Pl., 255.

trifolia, 255 .

Carduncellus minimus, 128.

Carduns eriophorus, 128.

", heterophyllux, 183-4.

Carlina acanthifolia, 129.

,$\quad$ acaulis, 128-9.

,, vulgaris, 129.

Catheartia lyrata, 60.

$$
\text { "villosa, } 60 \text {. }
$$

Cedrus atlantica Comte de Dijon, 445.

Centaurea (the race), 131.

Cerastium alpinum, 97.

" glaciale, 97.

, repens, 97.

, tomentosum, 97.

Chamaemelon caucasicum, 127.

Chimonanthus fragrans, 18, 19.

Chrysanthemum alpinum, 237. indicum, 238.

lapponicum, 238.

", $\quad$ nipponicum, 238.

", Zawadskyi, 238.

Chrysogonum virginianum, 127.

Cicendia pusilla, 241.

Cimicifuga davurica, 188.

Cistus (the race), 38-9.

Clematis (the race), 49 .

Cochlearia alpina, 64 .
Codonopsis ovata, 141.

Convolvulus arvensis, 139-40.

" mauritanicus, 140.

" Sabatius, 140.

" Soldanella, 140.

Corallorhiza innata, 222.

Coris monspeliensis, 149.

Cornus canadensis, 9.

„ suecica, 9 .

Coronilla emerus, 112-13.

, iberica, 113.

, varia, 112.

Cortusa Matthioli, 236.

Corydalis lutea, 60 .

" solida, 60 .

Cotoneaster pyrenaica, 44.

Crambe cordifolia, 255.

Cupressus torulosa, 45.

Cyclamen libanoticum, 138.

(the race), 138.

Cydonia Maulei, 44.

Cynoglossum apenninum, 145.

, pictum, 145.

Cypripedium acaule, 224.

$$
\begin{array}{ll}
\text {, } & \text { arietinum, 225. } \\
\text { cardidum, 224-5. } & \text { guttatum, 225. } \\
\text { " } & \text { parviflorum, 224-5. }
\end{array}
$$

Cystopteris alpina, 225.

" montana, 247.

Cytisus andreanus, 44.

, Ardoini, 108-9.

" biflorus, 109.

", incarnatus, 108.

", × kewensis, 109.

", pilosus, 43.

" procumbens, 109.

,, sagittalis, 44.

", schipkaensis, 109.

", tinctorius, 43.

Daphne arbuscula, 37 .

" fioniana, 36-7.

" Genkwa, 38.

", indica, 36 .

" mezereon, 38.

Delphinium (the race), 52.

Dianthus $\times$ cal.-alpinus, 95 . 
Dianthus integer, 94.

microlepis, 94.
roseus, 95.
", 'serotinus,' 95.

Digitalis ambigua, 150.

Dodecatheon integrifolium, 235. " Meadia, 235. ", paucifiorum, 235-6.

Dondia Epipactis, 119.

Doronicum Orphanidesi, 181. ", pardalianches, 181. ") plantagineum, 181.

Draba dicranoeides, 64.

" (the race), 63.

Drosera (the race), 245.

Echinops humilis, 129.

Eorecon chionantha, 254.

Epilobium angustifolium, 118, 184. " hirsutum, 118, 184.

Epipactis palustris, 223.

Epipogon aphyllum, 222.

Ereica (the race), 241.

Erigeron alpinus, 232.

Eriogyna pectinata, 139.

Erodium (the race), 106-7.

Eryngium glaciale, 119-20.

(the race), 120.

Erysimum comatum, 67.

", ochroleucum, 67.

" petrowskianum, 67.

" pumilum, 67.

, purpureum, 67.

Erythraea diffusa, 241.

Erythronium (the race), 150-1.

Eulalia zebrina, 187.

Ferula Linki, 119.

Festuca varia, 248.

Fragaria indica, 116.

" lucida, 116.

", vesca, 116-17.

Fritillaria (the race), 150 .

Fuchsia (the race), 24-5.

Galanthus Ikariae, 152.

$$
\text { ", poculiformis, } 152 .
$$

Gaultheria Shallon, 41.

", trichophylla, 42.
Gentiana acaulis, 225, 240.

, arvernensis, 240.

, asclepiadea, 183.

," bavarica, 226, 242.

, pumila, 240.

,, purpurea, 229.

,$\quad$ verna, $240,242$.

Geranium argenteum, 104.

, Richardsoni, 106.

" (the race), 105-6.

Geum bulgaricum, 116.

," montanum, 86-7.

, reptans, 87-8, 237.

, rhaeticum, 116.

Gunnera (the race), 185.

Gypsophila prostrata, 97.

1) (the race), 97.

Habenaria conopsea, 224.

Hedera minima, 44, 120.

Hedysarum (the race), 113.

Helianthemum (the race), 40.

Helleborus (the race), 50-1.

Helrine Soleiroli, 40, 258.

Heracleum mantegazzianum, 119.

Hieracium aurantiacum, 131.

Hottonia palustris, 270.

Houstonia coerulea, 121-2.

Hugueninia tanacetifolia, 78, 221.

Hutchinsia alpina, 64.

Hyacinthus amethystinus, 151 .

,, orientalis, 151.

Hypericum Coris, 103.

" olympicum, 101-2.

, repens, 102.

, reptans, 102.

Illicium religiosum, 42.

Iberis petraea, 65.

. (the race), 65.

Ionopsidion acaule, 92, 239.

Iris albo-purpurea, 211-12.

, attica, 195.

,, bosniacs, 196.

,Delavayi, 211.

, Horentina, 196-7.

,, foetidissima, 213.

, germanica, 196. 
Iris gigantea, 213.

, graminea, 200.

, Kaempferi, 204-6.

,, Kochii, 197.

, Korolkowi, 202-3.

, Lamancei, 202.

,, Monnieri, 213.

,, pallida, 197-8.

, prismatica, 200.

, pseud-acorus, 213-14.

,, reticulata, 199-200.

,, sibirica, 211.

,, tectorum, 197.

, unguicularis, 200-1.

Isopyrum thalictroeides, 55 .

Juniperus hibernica, 44.

, pachyphlaea, 44.

, prostrata, 44.

" sanderiana, $2,44$.

", virginiana Schotti, 45.

Kalmia alpina, 34.

, angustifolia, 34 .

, latifolia, 34 .

Lastraea (the race), 248.

Lathyrus latifolius albus, 113.

, magellanicus, 114.

", pratensis, 114.

, pubescens, 114.

, rotundifolius, 114.

", tuberosus, 114.

Lepachys columnaris, 130.

Lewisia rediviva, 137.

Tweedyi, 137-8.

Liatris (the race), 192.

Lilium alutaceum, 164 .

, X Alexandrae, 162.

, auratum and vars., 162-3.

, ," platyphyllum, 165.

,, avenaceum, 165.

, Batemanniae, 164.

,, $\times$ Burbanki, 161.

," callosum, 169-70.

", canadense, 170.

," chalcedonicum, 164, 169.

,, cordifolium, 165.
Lilium $\times$ Dal-Hansoni, 161 .

,, elegans, 164.

, giganteum, 166.

, Glehni, 165.

", Grayi, 167.

, Hansoni, 164.

, Heldreichi, 160.

, Henryi, 168.

, Humboldtii, 170.

, xMar-han, 161.

, maritimum, 170.

„Martagon and vars., 161.

", medeoloeides, 164-5.

", monadelphum, 163-4.

,, pardalinum, 167, 169, 173, 176.

Parryi, 162, 170.

pomponium, 164.

Roezlii, 168.

roseum, 164.

sulfureum, 167.

tenuifolium, 169.

tigrinum, 167.

Linaria (the race), 148-9.

Linum alpinum, 100.

,2 arboreum, 100.

, salsoloeides, 100-1.

, sibiricum, 101.

, viscosum, 101.

Lithospermum graminifolium, 143.

, (the race), 143-4.

Lloydia serotina, 122, 227-8.

Lobelia cardinalis, 267.

, Dortmanna, 268.

, radicans, 268.

Lupinus argenteus, 112.

,, decumbens, 112.

, nootkatensis, 112.

,, Snow-Queen, 112.

Lychnis alpina, 96.

, fulgens, 190.

$\therefore$ haageana, 189.

, Lagascae, 96.

, lapponica, 96.

," pyrenaica, 96.

," Sartorii, 96.

, Sartoril, 96.

, vespertina plena, 96 .

, viscarja, 96 . 
Magnolia (the race), 22.

Maianthemum bifolium, 222.

Malvastrum coccineum, 183.

Meconopsis aculeata, 56-7.

$" \quad$ bella, 58.
$" \quad$ cambrica, 57.
$\quad$ " aurantiaca plena,

, grandis, 58.

", heterophylla, 59 .

, horridula, 59.

,$\quad$ integrifolia, 58.

, nepalensis, 59.

$" \quad$ petiolata, 59 .

" punicea, 58.

" racemosa, 5 .

," simplicifolia, 58.

, Wallichi, 59-60.

Megacarpaea polyandra, 64 .

Mentha Requieni, 257-8.

Menyanthes trifoliata, 256-7.

Menziesia empetriformis, 273.

, polifolia, 41.

Mertensia (the race), 250.

Michauxia campanuloeides, 136.

, Tchihatchewi, 136.

Minulus Brilliant, 147, 270.

$$
\begin{array}{ll}
\text {, } & \text { cardinalis, } 147 . \\
, & \text { cupraeus, } 147 . \\
", & \text { Langsdorff, } 147 . \\
" & \text { Model, 147. } \\
" & \text { primuloeides, 147. } \\
, & \text { radicans, 147. }
\end{array}
$$

cHitella pentandra, 253-4.

Mulgedium :alpinum (Láctuca), 131, 221.

Bourgaei, 130.
$\quad \quad$ Plumieri, 130.

" thianshanicum, 130 .

Muscari (the race), 151.

Myosotis alpestris, 130.

" palustris, 232-3, 270.

" Rehsteineri, 257.

,, rupicola, 136, 23\%, 235 .

Myrrhiactis Wallichi, 129.

Narcissus (the race), 150.

" viridifforus, 153.
Narthecium ossifragum, 243.

Nelumbium speciosum, 29, 279.

Nigritella suaveolens, 232.

Nymphaea (the race), 276-8.

Oenothera (the race), 119.

Ononis (the race), 110.

Onopordon bracteatum, 128.

Onosma (the race), 144.

Orchis (the race), 223.

Orobus (the race), 114.

" hirsutus, 115.

" varius, 115.

Oxalis acetosella, 108.

", enneaphylla, 187-8.

", lobata, 108.

", rosea, 108.

Oxytropis (the race), 111.

" hybrida, 111-12.

" splendens, 112.

Paeonia Moutan, 5-8.

, (the race), 52-3.

Papaver tauricola, 60.

Paris quadrifolia, 273.

Parnassia fimbriata, 246.

" palustris, 246.

Parocbaetus communis, 256-7.

Parrya Menziesi, 64.

Pentatemon heterophyllus, 146-7.

Scouleri, 146.

Phlox (the race), 141-3.

" suffruticosa, 192.

Phyteuma (the race), 134-6.

Pinguicula (the race), 144.

Pinus cembra, 45, 78-9.

, koraiensis, 45 .

" massoniana, 45.

" montana, 45, 79 .

", sylvestris beuvronensis, 2, 44-5.

Poa alpina vivipara, 248.

Podophyllum Emodi, 190.

" peltatum, 190-1.

Polygala chamaebuxus, 99-100. rhodoptera, 100.

Vayredae, 100.

Polygonatum multiflorum, 269. verticillatum, 222. 
Polygonum baldschuanicum, 24. , cuspidatum, 23-4.

,$\quad$ Emodi, 22-3.

, saghalinense, 23.

,, sphaerostachyon, 23.

," vaccinifolium, 22-3.

, viviparum, 23, 244.

Polypodium calcareum, 247.

, dryopteris, 246-7.

, phegopteris, 247.

Pontederia cordata, 274.

Potentilla ambigua, 116.

, comarum, 256, 270.

,, floribunda, 13.

, Friedrichseni, 13.

,. fruticosa, 13.

, nitida, 13-14, 115.

", pulcherrima, 115 .

, Tongui, 116.

, Valderia, 115.

,, verna, 115.

Poterium canadense, 187.

Prenanthes purpurea, 130-1, 222.

Primula apennina, 234.

, auricula Golden Queen, 233.

,, bellunensis, 234 .

," cashmeriana, 235.

," cockburniana, 234.

, Deorum, 234.

,, glutinosa, 235.

, involucrata, 234.

" japonica, $234,270$.

" longiflora, 234.

, Obristii, 234.

" pulverulenta, 235,270 .

, rosea, 234.

"Sikkimensis, 235, 270.

", similis, 234.

, Stuarti, 234.

, $\times$ Unique, 234.

Prunus (the race), 18.

Pterocephalus Parnassi, 123.

Pulmonaria (the race), 145.

Pyrethrum (the race), 127.

Pyrus prostrata, 43.

, spectabilis, 18.

Ranunculus aconitifolius, 18, 232, 270.
Ranumeulus alpestris, 226, 232, 233, 242.

anemoneicles, 233.

Rheum palmatum, 185.

Rhexia virginica, 189.

Rhododendron (the race), 31-2.

$$
\text { , dilatatum, 32-4. }
$$

Rodgersia (the race), 185-6.

Rosa (the race), 14-7.

Rubus (the race), 9-11.

Salix alpina, 43.

Sanguinaria canadensis, 55-6, 254.

Saponaria caespitosa, 96.

, Iutea, 96-7.

, ocymoeides splendidissima, 96.

wiemanniana, 96.

Saussurea candicans, 129.

Saxifraga aeizoeides, 80, 238-9.

, aeizoỏn, 81-2.

, , lutea, 83.

, androsacea, 238.

, aquatica, 239.

, biflora, 238.

," corymbosa, 240 .

", Cymbalaria, 92, 239.

, dalmatica, 240.

, hieracifolia, 239.

" Hirculus major, 238.

,$\times$ jaeggeana, 240.

," Obristii, 240.

"Paulinae, 239-40.

, peltata, 186-7.

," pennsylvanica, 239.

, Petrarchae, 240.

Scabiosa caucasica, 123.

Scilla (the race), 151-?.

Sedum (the race), 133-4.

, villosum, 132, 219.

Sempervivum arachnoideum, 76-7.

$\begin{array}{ll}, & , \quad \text { transalpinum, } \\ & \text { calcaratum, } 77 . \\ \text { " } & \text { Gaudinj, 77. } \\ \text { Laggeri, 76-7. } \\ \text { ", } & \text { montanum, } 81 . \\ \text { rubicundum, } 77 .\end{array}$


Senecio adonidifolius, 180 .

," aurantiacus, 180.

", clivorum, 176-8.

" Doronicum, 180.

" japonicus, 178.

," pulcher, 179.

", thianshanicus, 179.

Serissa foetida, 19.

Silene (the race), 230-1.

Sisyrinchium anceps, 244.

$\begin{array}{ll}, & \text { bellum, 244. } \\ , & \text { grandiflorum, 244-5. } \\ \text { striatum, 245. }\end{array}$

Spigelia marilandica, 188-9.

Spiraea Aruncus, 12-13.

" digitata, 176-7.

" Hacquetti, 11-12.

") (herbrceous species), 173-7.

", (shrubby species), 11-13.

Stenanthium robustum, 192.

Streptopus amplexicaulis, 221-2.

Stylophorum diphyllum, 58.

Swertia perennis, 240-1.

Tchihatchewia isatidea, 67 .

Thalictrum (the race), 54-5.

Tofieldia canaliculata, 244.

Trientalis europaea, 139.
Trifolium alpinum, 111, 228. " canescens, 111.

Trillium grandiflorum, 273. " (the race), 274.

Valeriana (the race), 122.

Verbascum decorum, 150.

Veronica (the race), 228-9.

Vicia Cracca, 113, 169.

,, sylvatica, 113.

Viola arborescens, 253.

" biflora, 205.

" calcarata, 205.

" cucullata, 252.

" gracilis, 253.

", heterophylla, 253.

," hirta, 252.

" pedata, 251-7, 205.

" pinnata, chaerophylloeides, 253 (footnote).

" Rydbergi, 252.

" sorora, 252.

, stricta, 252.

Waldsteinia geoeides, 116.

Wistaria multijuga, 17.

Xerophyllum asphodeloeides, 192. 





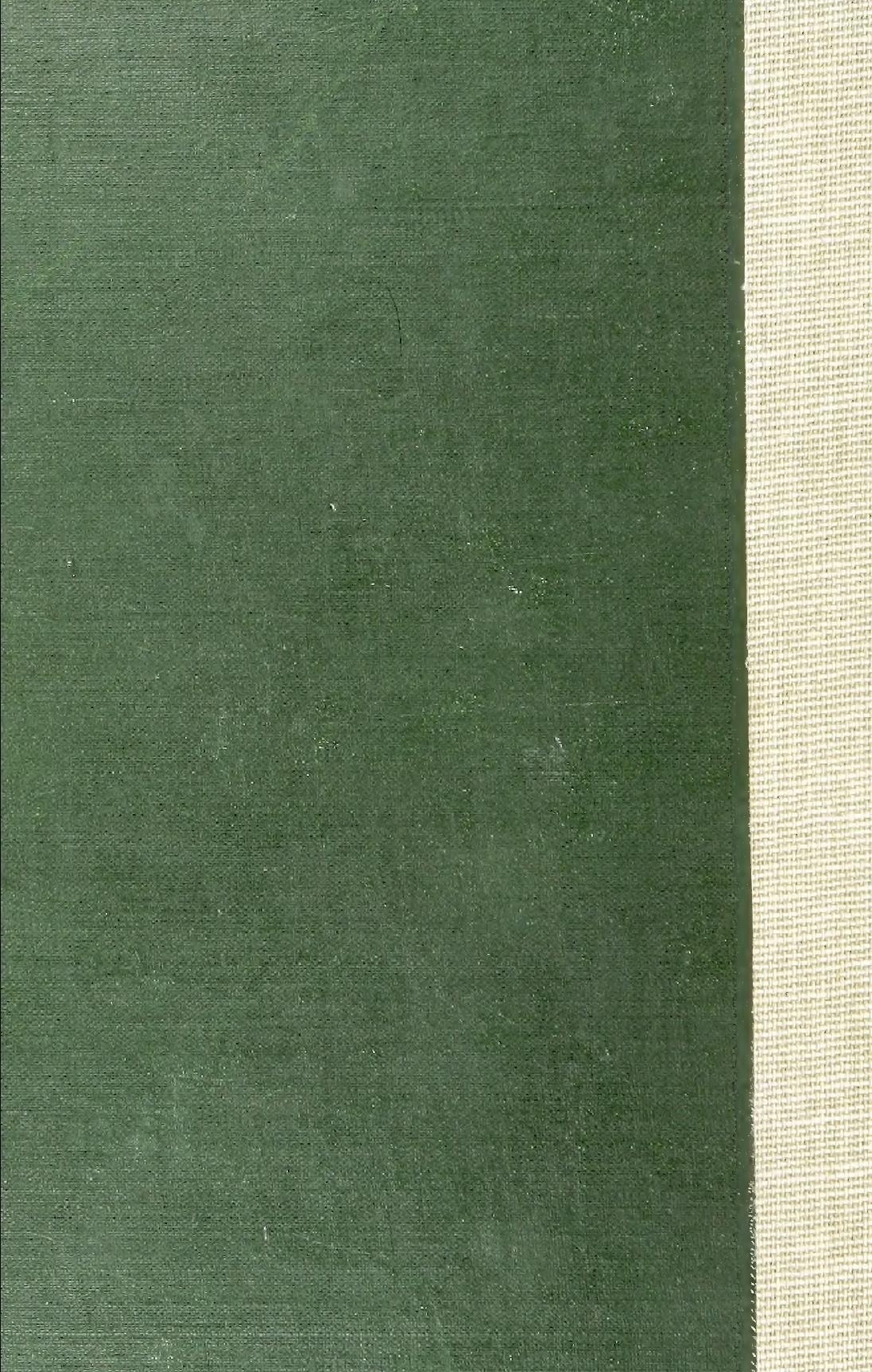

